Florida International University FIU Digital Commons

\title{
Conceptualizing American power and security in a post-9/11 security context : conflict, resistance, and global security, 2001-present
}

Marvin Astrada

Florida International University

DOI: $10.25148 /$ etd.FI14032363

Follow this and additional works at: https://digitalcommons.fiu.edu/etd

Part of the International and Area Studies Commons

\section{Recommended Citation}

Astrada, Marvin, "Conceptualizing American power and security in a post-9/11 security context : conflict, resistance, and global security, 2001-present" (2008). FIU Electronic Theses and Dissertations. 1355.

https://digitalcommons.fiu.edu/etd/1355 
FLORIDA INTERNATIONAL UNIVERSITY

Miami, Florida

CONCEPTUALIZING AMERICAN POWER AND SECURITY IN A POST-9/11

SECURITY CONTEXT: CONFLICT, RESISTANCE, AND GLOBAL SECURITY, 2001-PRESENT

A dissertation submitted in partial fulfillment of the

requirements for the degree of

DOCTOR OF PHILOSOPHY

in

INTERNATIONAL RELATIONS

by

Marvin Astrada 
To: Dean Kenneth Furton

College of Arts and Sciences

This dissertation, written by Marvin Astrada, and entitled Conceptualizing American Power and Security in a Post-9/11 Security Context: Conflict, Resistance, and Global Security, 2001-Present, having been approved in respect to style and intellectual content, is referred to you for judgment.

We have read this dissertation and recommend that it be approved.

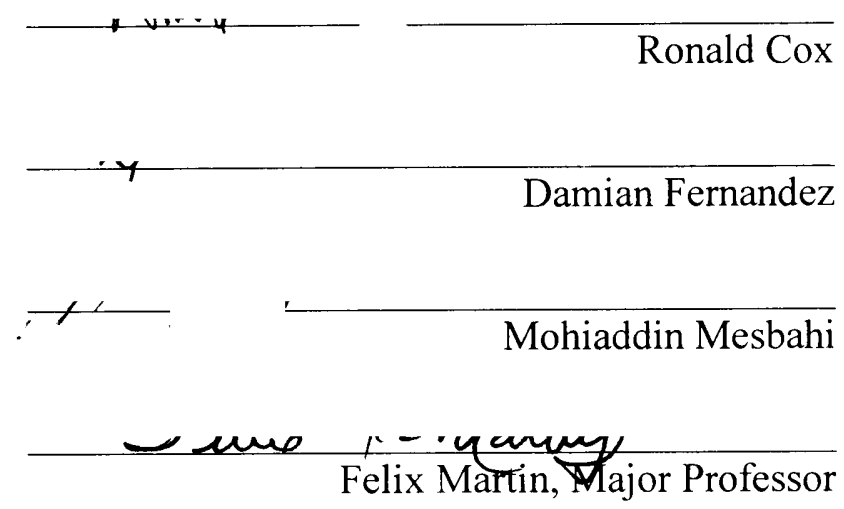

Date of Defense: June 12, 2008.

The dissertation of Marvin Astrada is approved.

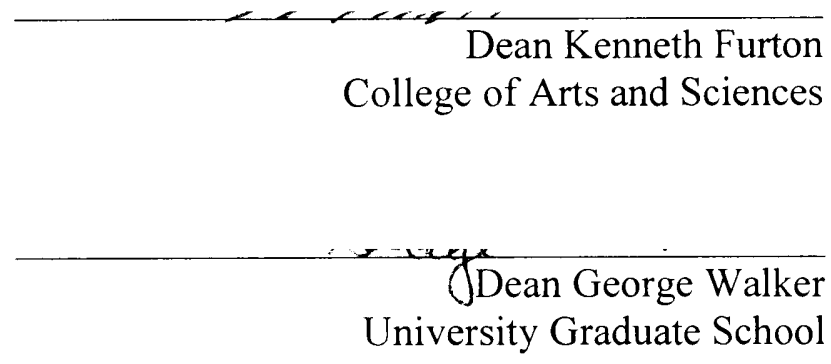

Florida International University, 2008 
(C) Copyright 2008 by Marvin Astrada All rights reserved. 


\section{DEDICATION}

I dedicate this dissertation to the two people who have played an integral role in completing my doctoral course of study. First, my mother, Alexandra Astrada, has been invaluable in providing a superabundance of information, ideas, and inspiration since I began my academic sojourn. Her conviction that intellectual inquiry, analysis, and critical self-reflection are requisite to any project that seeks to explain as well as understand the complexities and conundrums of the human condition under-girds this dissertation. Indeed, her life is a testament to the capacity of human beings to explain as well as understand what it means to be "human, all too human," in an intricately complex world that is and is not of our making. I also wish to dedicate this work to Helga Turku, who proved a wellspring of inspiration and support throughout the entire dissertation process. She displayed verve and immense patience in reading, commenting, and discussing this work for the past 18 months, providing constructive insight and emotional support throughout the extensive process. Mr. and Mrs. William and Jeanie Graustein have also played a profound role in my academic and personal life experience; indeed, I could not have reached this point without their support. Lastly, I could not have completed this work without Tiberius and Lilly, who provided much-needed diversion from time to time. 


\section{ACKNOWLEDGMENTS}

First and foremost, I wish to acknowledge the resolute commitment of Dr. Felix E. Martin, my major professor, in guiding me throughout the very long and difficult process of conceptualizing, researching, writing, and editing this dissertation. I truly appreciate and am indebted to Dr. Martin for the immeasurable of amount of time and effort he invested in the dissertation. His participation in every step of the process was, quite simply, indispensable to the completion of this work. I also wish to express my gratitude to Dr. Ronald Cox, Dr. Damian Fernandez, and Dr. Mohiaddin Mesbahi for being on my dissertation committee. Lastly, I wish to express my sincerest appreciation to the University Graduate School, Florida International University, Miami, Florida, for providing me with a generous 2008 Dissertation Year Fellowship to support my dissertation research and writing. The Fellowship was instrumental in enabling me to devote myself full-time to completing the dissertation. 


\section{ABSTRACT OF THE DISSERTATION 2001-PRESENT \\ by \\ Marvin Astrada \\ Florida International University, 2008 \\ Miami, Florida \\ Professor Felix Martin, Major Professor}

CONCEPTUALIZING AMERICAN POWER AND SECURITY IN A POST-9/11

SECURITY CONTEXT: CONFLICT, RESISTANCE, AND GLOBAL SECURITY,

In a post-Cold War, post-9/11 world, the advent of US global supremacy resulted in the installation, perpetuation, and dissemination of an Absolutist Security Agenda (hereinafter, ASA). The US ASA explicitly and aggressively articulates and equates US national security interests with the security of all states in the international system, and replaced the bipolar, Cold War framework that defined international affairs from 19451992. Since the collapse of the USSR and the 11 September 2001 terrorist attacks, the US has unilaterally defined, implemented, and managed systemic security policy.

The US ASA is indicative of a systemic category of knowledge (security) anchored in variegated conceptual and material components, such as morality, philosophy, and political rubrics. The US ASA is based on a logic that involves the following security components: 1 ., hyper militarization, 2 ., intimidation, 3 ., coercion, 4 ., criminalization, 5., panoptic surveillance, 6., plenary security measures, and 7., unabashed US interference in the domestic affairs of select states. Such interference has produced destabilizing tensions and conflicts that have, in turn, produced resistance, 
revolutions, proliferation, cults of personality, and militarization. This is the case because the US ASA rests on the notion that the international system of states is an extension, instrument of US power, rather than a system and/or society of states comprised of functionally sovereign entities.

To analyze the US ASA, this study utilizes: 1., official government statements, legal doctrines, treaties, and policies pertaining to US foreign policy; 2., militarization rationales, budgets, and expenditures; and 3., case studies of rogue states. The data used in this study are drawn from information that is publicly available (academic journals, think-tank publications, government publications, and information provided by international organizations).

The data supports the contention that global security is effectuated via a discrete set of hegemonic/imperialistic US values and interests, finding empirical expression in legal acts (USA Patriot ACT 2001) and the concept of rogue states. Rogue states, therefore, provide test cases to clarify the breadth, depth, and consequentialness of the US ASA in world affairs vis-à-vis the relationship between US security and global security. 


\section{TABLE OF CONTENTS}

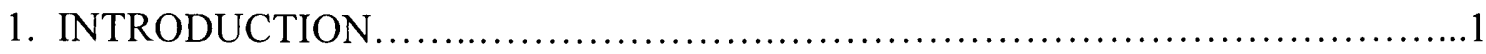

Methodology \& Purpose ............................................................. 5

A Single-Minded Epistemology of Security ........................................ 8

Utility of Universal Foes........................................................ 16

Destabilizing the States System................................................21

US Imperialism \& Hegemony................................................ 24

Global Enemies, Militarization \& Ideology ....................................29

Morality \& Global Governance............................................... 34

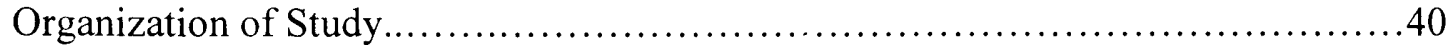

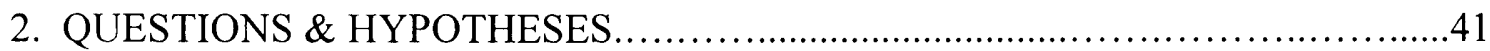

Power, Morality \& Terror......................................................... 47

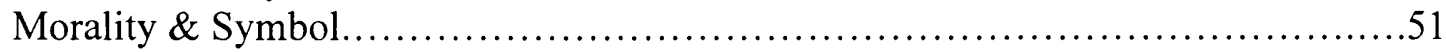

Security \& Rules of Formation.................................................. 59

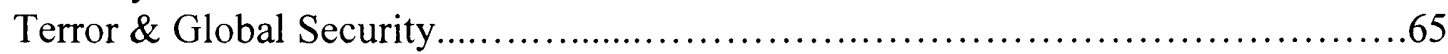

Internationalizing the War on Terror.......................................... 80

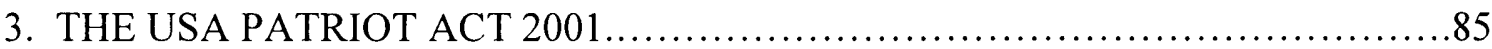

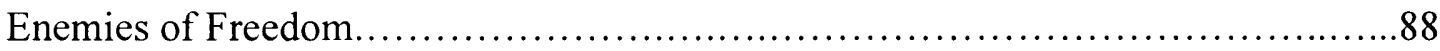

Waging War to Wage Peace................................................. 103

Conclusion.............................................................. 108

4. WMD \& PROLIFERATION ............................................... 113

The Post-9/11 Nuclear Threat.................................................. 115

Rogue States \& WMD........................................................ 124

North Korea \& WMD ...................................................... 127

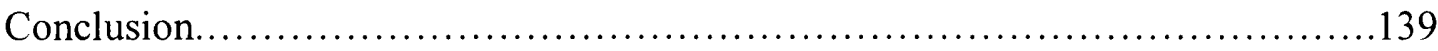

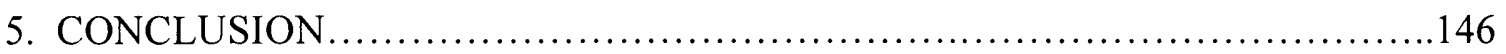

BIBLIOGRAPHY ..................................................... 159

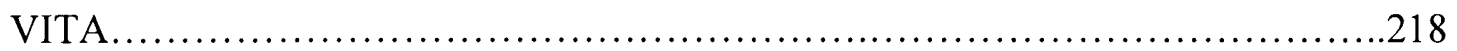


Whosoever undertakes to set himself up as [the ultimate] judge in the field of Truth and Knowledge is shipwrecked by the laughter of the gods. Albert Einstein (1953). ${ }^{1}$

\section{CHAPTER 1. INTRODUCTION}

In a post-9/11 world, US global supremacy has resulted in an attempt to install and disseminate an absolutist security agenda (hereinafter, ASA). The US ASA explicitly and aggressively articulates and equates US domestic security interests with the security of all states in the international system. Since the collapse of the USSR and the 9/11 terrorist attacks, the US has sought to unilaterally define, implement, and manage systemic security policy. The ASA is based on a security logic that involves a blend of militarization, intimidation, coercion, criminalization, panoptic surveillance, plenary security, US domestic security as the basis for global security, and US interference in the affairs of select states. Generally speaking, US interference, based on security interests, historically and presently, has produced destabilizing tensions and conflicts that have, in turn, produced revolutions, proliferation, and militarization on the world stage. ${ }^{2}$ This is the case because US security is premised on the notion that the system of states is an extension and instrument of US power, subject to its specific security interests.

The US ASA involves utilization of interactive material and intangible components that inform, complement, and produce a rubric of security, such as ideology, morality, military capacity, and politics. This being the case, a macro-systemic perspective is employed to analyze and derive conclusions about the post-9/11 security

\footnotetext{
${ }^{1}$ Albert Einstein, Ideas \& Opinions, ed. Carl Seelig, trans. Sonja Bargmann, intro. Alan Lightman (New York: Random House, 1994) 30.

${ }^{2}$ See Hedley Bull, The Anarchical Society: A Study of Order in World Politics $2^{\text {nd }}$ ed., forward Stanley Hoffmann (New York: Columbia University Press, 1995).
} 
context. A systematic set of concepts and practices, empirical and intangible, function in tandem within an interdependent set of organizational relationships to articulate and implement security policy. ${ }^{3}$ Morality, politics, nationalism, ideology, and law, for example, are abstract as well as empirical components of a system of security that do not occur in a vacuum. Components function in an interactive and interdependent context, and are both products and producers of knowledge and conceptualization within a larger system of organization, hierarchy, and power. Security components reflect "a way of thinking having the proportions of a world view."4

A systemic and systematic epistemology of security is comprised of diverse, organized, and complex variables. While security may seem a stable and closed category, it is rather complex and open, comprised of various constituent epistemic and material components. Security components are dynamic and multidimensional, composed of various epistemologies (nationalism, culture, the scientific method) of truth and understanding. The US ASA seeks to provide a unitary, homogenous template for the apprehension, comprehension, and articulation of global security based on specific universal and objective postulations of morality, ideology, politics, legality, economy, and military power that operate in an ordered hierarchy. Disaggregating the ASA fleshes out the "teleological mechanism" that under-girds the post-9/11 global security context. ${ }^{5}$

\footnotetext{
${ }^{3}$ See Ervin Laszlo, The Systems View of the World: A Holistic Vision for Our Time Advances in Systems Theory, Complexity, and the Human Sciences (Cresskill: Hampton Press, 1996); Ervin Laszlo, The Systems View of the World: The Natural Philosophy of the New Developments in the Sciences (New York: George Braziller, 1972).

${ }^{4}$ Charles McClelland, "General Systems Theory in International Relations," International Security Systems: Concepts \& Models of World Order, ed. Richard B. Gray (Itasca: F. E. Peacock, 1969) 21.

${ }^{5}$ Ludwig Von Bertalanffy, General Systems Theory: Foundations, Development, and Applications (New York: George Braziller, I968) 16-17. Also see, Ludwig Von Bertalanffy, A Systems View of Man, ed. Paul A LaViolette (Boulder: Westview Press, 1981).
} 
Implementation of an ASA supports the contention that the US has seized the "unipolar moment" that manifested itself after the socioeconomic and political implosion of the USSR. ${ }^{6}$ Although divergent perspectives have arisen claiming that the "unipolar moment" can be considered illusory or genuine, empirically it is the case that the "geopolitical [and military-power] structure of the post-Cold War world ... is [embodied in] a single pole of world power that consists of the US [being] at the apex" of systemic organization and management of global affairs. ${ }^{7}$ While a distribution of material power capabilities is vital to explaining the dynamics and structure of the international system, an analysis of the US ASA takes into account the various and equally important nonmaterial components that have a considerable effect on the whole of international affairs. For example, a phenomenon, an abstraction, that is, terror, is a primary impetus of the global security agenda pursued by the US as opposed to identifiable state actors. Given the globalized nature of the modern world system, the dissemination of a universal culture (consumerist), enemy (terror), political system (procedural democracy), mode of hyper-consumption (transnational corporate power, global economy), development aid (substantial US influence in the IMF, Word Bank, WTO), and environmental security factors (ozone depletion, global warming), amongst several others, have a profound effect on how security is conceptualized and implemented in a post-9/11 world. Each is grounded in different knowledge systems that have distinct priorities, concepts, and explanations of international affairs and security.

\footnotetext{
${ }^{6}$ See Charles Krauthammer, “The Unipolar Moment," Foreign Affairs 70.1 (1990/91) 23-33.

${ }^{7}$ Krauthammer 24. Also see Robert Jervis, "International Primacy: 1s the Game Worth the Candle?" International Security 17.4 (Spring 1993) 52-67; Christopher Layne, "The Unipolar Illusion: Why New Great Powers Will Rise," International Security 17.4 (Spring 1993) 5-51; Christopher Layne, "Rethinking American Grand Strategy: Hegemony or Balance of Power in the Twenty-First Century?" World Policy Journal (Summer 1998) 8-41.
} 
Thus, this study seeks to expound upon the composition, dynamics, and consequences of the post-9/11 security context. To accomplish this goal, the following overarching research question grounds this study: how has the event of $9 / 11$ further enabled the US to legitimately articulate, disseminate, and implement an absolutist security agenda on the world stage $?^{8}$ This dissertation contends that post-9/11 security policy, although part of a historical trajectory of (hegemonic) US power, differs from traditional US policy in that there is no longer a viable counterweight to rein in US power prerogatives. Since the Post-World War II period and the subsequent Cold War, US power and global aspirations were effectively balanced by the USSR. After the demise of the USSR, the US was, relatively speaking, given free reign to define the contours and parameters of post-Cold War global affairs. The event of $9 / 11$ is indicative of continuity as well as change in how US security policy is defined and implemented. Asserting profound influence/ control over world affairs through force and the threat of force remains the case, but the barriers to obtaining such influence/control have been significantly attenuated. Indeed, with the advent of an "age of terror" (formally inaugurated on $9 / 11 / 2001$ ), the US has been able to "legitimately" posit a new world order based on its exclusive domestic national security interests. There is no viable, legitimate alternative (according to US security policy) to defining global affairs than the US template; for example, socialism and communism as competing or alternative ideologies are considered antiquated forms of governance that hold no place in the US managed world order. US absolutist security policy decrees this is the case because any

\footnotetext{
${ }^{8}$ Regarding the dynamics and consequences of paradigmatic change in scientific understanding, see Thomas Kuhn, The Structure of Scientific Revolutions $3^{\text {td }}$ ed. (Chicago: University of Chicago Press, 1996).
} 
alternative forms of governance are incompatible with the US ASA, which flippantly ignores the diversity inherent in a system of sovereign states. The US disseminates its policy of "US security = global security" through a variety of means, such as law, force, propaganda, alliances, and economy. With no significant opposition, the US is able to postulate and proffer its ASA as being the singular course of action to effectuate a secure state of affairs in the conduct of state interactions. This occurs on a variety of levels, and the event of $9 / 11$ has enabled the US to "legitimately" wage multifarious warfare against material and non-material threats and enemies. This has resulted in total war being formally waged against concepts, ideas, groups, states, and individuals. In an age of terror, the US has constructed and disseminated a particular epistemology of how and why to securitize, and this directly impacts what security in essence means for all actors in the international system.

Methodology \& Purpose

The US ASA will be examined via a discursive and interpretative content analysis of US security policy toward select "enemies" of global peace and freedom (rogue states), unilateral criminalization of terror (USA Patriot Act 2001), and the proliferation of weapons of mass destruction (hereinafter, WMD) vis-à-vis North Korea. US policy toward rogue states provides a means for examining the ASA. The power to define what a state is and should be is indicative of the degree of influence the US wields in international affairs, and how the US has been able to repackage Cold War concepts to suit a unipolar security context. The event of $9 / 11$ provided the US with an imprimatur of legitimacy and necessity in retaining its power to manage and define security vis-à-vis 
good and malevolent states in absence of the ominous Soviet threat that had legitimated US policy during the Cold War. The category of rogue state has been redefined to create a viable state enemy in an age of unmitigated, ubiquitous terror. $9 / 11$ provided an ideological, moral, and military justification for the US to augment rather than decrease its influence and control over world affairs. Rogue states, which previously defied US power by resisting US hegemony politically and militarily, are now defined as statesponsors of terror that arm to threaten the peace of the world. As for terror and its criminalization, it exemplifies the "change" in global security under the ASA, which involves creating a systemic epistemology of security based on US plenary notions of macro threat prevention and preemption. As is the case with the power to categorize states, the event of $9 / 11$ enabled the US to pursue its traditional hegemonic agenda clothed in the garb of a paladin striving to preserve the entire world from an insidious and deadly enemy (terror) that could be "found" virtually anywhere and in any form.

While this study can be termed "critical," it is imperative to note what this study does and does not seek to accomplish. Regarding the former, this study aspires to provide an analysis of security. Polemics, the correctness or impropriety of a particular political model of international society and/or world politics, and the like are not in line with this study's notion of critical analysis. Rather, this study follows a Foucauldian conception of critical analysis: “when I say 'critical,' I don't mean a demolition job, one of rejection or refusal, but a work of examination that consists of suspending as far as possible the system of values to which one refers when testing and assessing it."

\footnotetext{
${ }^{9}$ Michel Foucault, Politics, Philosophy, and Culture: Interviews \& Other Writings 1977-1984, trans. Alan Sheridan, ed. and intro. Lawrence D. Kritzman (New York and London: Routledge, 1988) 107.
} 
Although subject to in-depth critique, the US, in and of itself, is not the object of critique. Rather, a critique of US power and its global security agenda provides a means to explain and understand security in a post-9/11 security context. Einstein's observation of US power in 1921 retains its validity: "the US is the most powerful among the technically advanced countries in the world today. Its influence on the shaping of international relations is absolutely incalculable."10

An examination of US security policy from the Cold War through the present suggests continuity as well as change. ${ }^{11}$ Continuity can be observed in the sustained relevance of key concepts that continue to anchor the international system; for example, states remain the primary international actors. Yet, change in how international affairs are conceptualized since the establishment of the modern world system in Bretton Woods, New Hampshire (1944) has also occurred. In particular, the US being at the apex of power in a unipolar position, supported by the most advanced technology and military organization in the world to wage war against a concept (terror), has significantly impacted traditional notions of sovereignty and other basic ordering principles of international relations. Through calculated use of the event of $9 / 11$, the US has been able to augment its power by retaining the language and categories of a system of states, particularly notions of security, sovereignty and self-determination, while reconfiguring the content of international order in a unipolar image in the name of global security.

\footnotetext{
${ }^{10}$ Einstein 7.

${ }^{11}$ See James R. Kurth, "A Widening Gyre: The Logic of American Weapons Procurement," American Foreign Policy: Theoretical Essays $3^{\text {rd }}$ ed., ed. G. John lkenberry (New York: Longman, 1999) 14-36; Ole R. Holsti, "Models of International Relations \& Foreign Policy," American Foreign Policy: Theoretical Essays $3^{\text {rd }}$ ed., ed. G. John Ikenberry (New York: Longman, 1999) 37-64; G. John Ikenberry, "The Myth of Post-Cold War Chaos," Foreign Affairs 75.3 (May/June 1996) 79-91.
} 
The US ASA bestrides the divide between continuity and change. Although US security policy has been characterized as moving in cycles between isolationism, internationalism, bilateralism, multilateralism, and intense to detached involvement in international affairs, there is an historical hegemonic imperative that under-girds US foreign policy. ${ }^{12}$ As Christopher Layne notes, the US's "grand strategy," that is, commanding an absolute preponderance of power, did not fundamentally change between 1945-1991. Hegemonic "ambitions, interests, and alliances," backed by tremendous military power and moral convictions, have been the enduring hallmarks of US security policy. ${ }^{13}$ "Continuity is the leitmotif of US foreign policy, and the unilateral pursuit of national interests ... has strong precedent. What makes today's unilateralism different from that of the past[, however,] is the international and domestic context in which it is being carried out[, that is,] the war on terrorism, the absence of a counterweight to US power, and the single-mindedness ... of American primacy"14

\section{A Single-Minded Epistemology of Security}

The US is held out as the singular means to obtain universal eudemonia (Aristotle), that is, universal happiness, stability, purpose, and freedom based on US

\footnotetext{
${ }^{12}$ See Mel Gurtov, "American Crusades: Unilateralism, Past \& Present," Confronting the Bush Doctrine: Critical Views From the Asia-Pacific, eds. Mel Gurtov and Peter Van Ness (London: Routledge-Cruzon, 2005) 1-39; Amy Kaplan and Donald E. Pease, eds., Cultures of United States Imperialism (Durham: Duke University Press, 1993); Edward W. Said, Culture and Imperialism (New York: Vintage Books, 1994); John Bellamy Foster, Naked Imperialism: The U.S. Pursuit of Global Dominance (New York: Monthly Review Press, 2006); J. A. Hobson, Imperialism: A Study (New York: Cosimo Press, 2005); David Ryan, US Foreign Policy in World History (New York: Routledge, 2000); Michael Hudson, Super Imperialism: The Origin and Fundamentals of US World Dominance $2^{\text {nd }}$ ed. (London: Pluto Press, 2003); Charles-Philippe David and David Grondin, eds., Hegemony or Empire? The Redefinition of US Power Under George W. Bush (Burlington: Ashgate, 2006).

${ }^{13}$ Christopher Layne, "From Preponderance to Offshore Balancing," America's Strategic Choices, eds. Michael Brown, et al., (Cambridge: Massachusetts Institute of Technology University Press, 1997) 244-82.

${ }^{14}$ Gurtov 1 .
} 
security logic and precepts. US security policy is no longer overtly belligerent and imperialistic. Under the ASA, US power, policy, and interests are presented as munificent and indispensable for establishing the objective conditions requisite for perpetual global peace, freedom, and security. By arrogating to itself the exclusive right to define one of the most essential tasks of every state actor, that is, security, the US perpetuates an epistemology of security to effectuate a "transubstantiation" between the US order-combine, that is, the general political, social, moral, legal, cultural, ideological, and economic components of the US state, the states system, and international society. This transubstantiation is, at the very least, plausible because the specter of $9 / 11$ provides a basis for articulating and implementing the US ASA. Furthermore, although $9 / 11 \mathrm{can}$ be traced to US interference in the affairs of other states/polities, it has been effectively utilized by the US to not only justify victim status but also legitimate US exceptionalism in order to pursue an unhampered, aggressive ASA for the sake of global peace and justice. By manufacturing security needs based on the $9 / 11$ event, the US is able to posit an absolutist security policy as the only satisfactory response to fulfill all states' needs. Under the US ASA, the US becomes the singular author of what constitutes threats and what measures address such threats; US policy becomes a requisite precondition for any discourse vis-à-vis global security. The event of $9 / 11$, in and of itself, has enabled the US to pursue an unfettered campaign to exercise plenary control over world affairs based on the ubiquitous threat of malevolent terror.

Historically, the basis for US security policy has fluctuated between unilateralists, "who in the grand tradition of George Washington and the Founding Fathers eschew entangling relationships, and internationalists [in the Wilsonian tradition], who advocate 
cooperation and see security relationships as effective instruments for controlling the behavior of partners." "15 The US ASA, however, offers a template for global order based on a security management strategy that blends unilateralism, bilateralism, and multilateralism (backed with overwhelming military and economic power), with US security as the lodestar defining global security policy. This strategy promotes and consolidates "a new global political and economic order congenial to American state interests ... [and] this ... has been central to the constitution of the post World War II, 'new world order.' The US has employed a combination of coercive and consensual means and [has] succeeded in encouraging (and often forcing) other states" to abide by and implement its policy. ${ }^{16}$ The US ASA augments traditional notions of exertion of "naked" power and multilateralism by promoting:

Disciplinarian neo-liberalism and constitutionalism as the basis of global restructuring and politico-juridical reform; the hyperextension of an emerging market civilization; explicit and implicit US dominance of global economic policy; the forcible implementation of US ideological and moral values and modalities via force, economy, and procedural democratic political systems; and the US as the vanguard and indisputable 'author' and manager of world affairs. ${ }^{17}$

Where the present ASA fundamentally departs from pervious security policy, rubrics, etc., is that US security after $9 / 11$ constitutes an explicit universal, objective, systemic,

\footnotetext{
${ }^{15}$ Fraser Cameron, US Foreign Policy After the Cold War: Global Hegemon or Reluctant Sheriff? $2^{\text {nd }}$ ed. (London: Routledge, 2005) 183. Also, see Charles Williams Maynes, "Principled Hegemony," World Policy Journal 14.3 (Fall 1997) $31-37$.

${ }^{16}$ Stephen Gill, Power \& Resistance in the New World Order (New York: Palgrave-MacMillan, 2003) 69.

17 Gill 67. Also, see Benjamin Barber, Jihad vs. McWorld: How Globalism and Tribalism Are Reshaping the World (New York: Ballantine Books, 1996).
} 
superior system of security. ${ }^{18}$ Security, premised on US state-specific criteria, is posited as being comprised of axiomatic, organic categories such as freedom, peace, democracy, and justice that cannot be challenged. Resistance to the US ASA is dubbed aberrant and irrational, and merits stern, militaristic, and overtly hostile responses premised on objective truth. These changes have far-reaching consequences on the character and conduct of international affairs. The realm of "facts" as presented under the ASA, for example the singular meaning given to $9 / 11$ by the US, is inextricably linked with a specific moral terrain and form of ethical judgment. Through acts of authoritatively naming the constituent elements of the world, systems of knowledge are able to "identify" or "discover" first principles and bestow them upon objects/states of affairs that pre-exist human cognition. Perceptions, however, are based upon and function within inter-relational, relative, prescribed knowledge systems that can only appeal to internal, self-contained rationalization.

The US ASA proceeds by utilizing specific, moral perceptions as immutable bases of an objective international reality based on the specter of $9 / 11$ terror and its indeterminate replication. Perception, conception, explanation, and understanding devolve from the establishment of an epistemology of truth. Epistemology establishes the range of human possibility, and ultimately has the potential to "capture," appropriate, and delimit ordering concepts. The ASA provides the US with a claim of a "monopoly of wisdom" pertaining to the conceptualization and implementation of security. ${ }^{19}$ The idea

\footnotetext{
${ }^{18}$ Noam Chomsky and Michel Foucault, The Chomsky-Foucault Debate On Human Nature, forward John Rajchman (New York: New Press, 2006) 1-35.

${ }^{19}$ E. H. Carr, The Twenty Years' Crises, 1919-1939: An Introduction to the Study of International Relations (New York: Harper and Row, 1964) 52.
} 
of the world that "we entertain becomes a filter through which we pass our data." ${ }^{20}$ Ideas are based on systemic epistemologies and form the conceptual "media" of global security, for example, procedural democracy, peace, and security as defined by the US. As Marshall McLuhan observes, "we become what we behold ... we shape our [epistemic] tools, and therefore our tools shape us." ${ }^{21}$ This state of affairs is noteworthy because power and its exercise are premised on the capacity to fix signification via naming things. Epistemologies thus create circumscribed conceptual spaces of possibility and actuality, which are established and mediated by an authority that governs by establishing objective signifiers. ${ }^{22}$ The contextual "space" manufactured by epistemologies assumes a weighty role in setting the limits and possibilities of legitimating the ideologies that under-gird security frameworks and policy.

A reevaluation of fundamental international ordering concepts such as security, sovereignty, hegemony, and rogue states is in order given the changed global security context since the event of $9 / 11$. Reappraisal of security in particular is merited since "the more a man is imbued with the ordered regularity of ... events the firmer becomes his conviction that there is no room left by the side of this ordered regularity for causes of a different nature." 23 Systemic concepts that have structured security discourse and policy since 1945 have been subject to reconfiguration under the US ASA. For example: a.) Terror and radical fundamentalism are not deterred by rational calculations; b.)

\footnotetext{
${ }^{20}$ Kenneth N. Waltz, Man, the State, and War: A Theoretical Analysis (New York: Columbia Press, 2001) 10.

${ }^{21}$ Marshall McLuhan, Understanding Media: The Extensions of Man, intro. Lewis H. Lapham (Cambridge: Massachusetts Institute of Technology Press, 2002) xi.

${ }^{22}$ Martin Hollis and Steve Smith, Explaining \& Understanding International Relations (New York: Oxford 1990) 83.

${ }^{23}$ Einstein 51.
} 
Sovereignty has become more and more hollow, attenuated by the hegemon to implement its ASA; c.) Containment, given ubiquitous terror, can apply to any and all state activities in the realm of defense and wellbeing; and d.) Balance of Power has been reconfigured so as to privilege one state's power as the singular ballast for the international system based on objective moral, economic, and political principles/precepts backed by overwhelming military power.

Generally speaking, a totalizing US war on terror has sought to change the form and substance of international security policy, creating a "system [of security] with neither close nor center." 24 The US ASA and the war on terror contradict three fundamental principles within the context of a states system, that is, the Treaty of Westphalia, UN Charter, and Nuremberg Court. ${ }^{25}$ Each privileges sovereignty and selfdetermination of states in the conduct of international relations; the US $A S A$ has sought to reconfigure these fundamental principles. Also, the US war on terror has radically redefined the context and concept of "foes," and what constitutes a global security "threat." The US has "redefined who is a [global] ally [of peace] and who is an enemy ... [and the] relevance of the long-standing strategic doctrines of containment and deterrence." ${ }^{26}$ In light of the US $A S A$ and notions of terror, the previous bi-polar security system, premised on clearly defined foes presenting clear threats, is no longer the case. "With the demise of communism and the disappearance of the Soviet Union, the US

\footnotetext{
${ }^{24}$ See Roland Barthes, "The Death of the Author," trans. Stephen Heath, The Norton Anthology of Theory and Criticism, eds. Vincent B. Leitch, William E. Cain, Laurie A. Fink, Barbara E. Johnson, John McGowan, and Jeffery J. Williams (New York: W.W. Norton, 2001) 1472.

${ }^{25}$ Bruce Urquhart, "World Order \& Mr. Bush," New York Review of Books, 9 Oct. 2003.

${ }^{26}$ John W. Dietrich, ed., The George W. Bush Foreign Policy Reader: Presidential Speeches With Commentary (New York: M.E. Sharpe, 2005) 10.
} 
global strategy is entering a phase in world history never witnessed before by any 'great power," that is, a single power is primus inter pares in a system of sovereign states. ${ }^{27}$ The US $A S A$, therefore, involves the trans-nationalization of "political processes and systems, involving changes and shifting structures in world politics, political economy, ideology, and power relationships" in line with US security mandates. ${ }^{28}$ In sum, the US seeks to substantially re-configure a sovereign states-system to conform to a unipolar system via homogenization of security policy.

Mass dissemination of discrete US values, interests, and material practices find empirical expression in, amongst other things, officially US-designated "enemies" of global peace and prosperity. While states such as Russia and China are significant rivals to US power, they are nevertheless not "official" enemies of global order. Indeed, these states are immediately crucial to global economic and political stability; they possess large economies, nuclear weapons, overwhelming military power, and are full, active participants in conducting global affairs. Indeed, states such as Russia and China can benefit from the US unipolar system (especially economically), so long as essential notions of sovereignty are in fact respected in the formulation of US foreign policy. The US, in turn, has vested interests in ensuring a peaceful and productive coexistence with Russia and China, and vice versa. Other weaker state actors, on the other hand, such as Iran, North Korea, Burma, and Cuba, possess pernicious values and incongruous interests that range from mild to fervent opposition to US global leadership and security

\footnotetext{
${ }^{27}$ Thanh Duong, Hegemonic Globalization: US Centrality \& Global Strategy in the Emerging World Order (Burlington: Ashgate Publishing, 2002) 10.

${ }^{28}$ Duong 11-12.
} 
interests. $^{29}$ These specific enemies, that is, rogue states, are part of a grand ideological justification for US global military and economic supremacy in a post-9/11 security context. According to US President George W. Bush, all enemies of the US hate a "world, shaped by American courage, power and wisdom, [which] now echoes with American ideals ... a [world] defended by democracy, nurtured by free markets, spread by information technology, carried to the world by free trade ... [US enemies] hate our values and resent our success. ${ }^{30}$

The event of $9 / 11$ has enabled the US to moralize its security policy, to objectively interpret "facts" and "threats," to frame security in moralistic and ethical terms. The US "struggle" against enemies of peace and freedom is therefore presented as a righteous campaign to bring freedom, peace, and stability to the world. The US campaign has universal moral and ideological overtones that have the effect of fueling as opposed to tempering resistance to US power, thereby fomenting global insecurity. The contest between the objective embodiment of goodness and truth (the US) versus objective, unadulterated "evil" (rogue states, ubiquitous terror) creates a binary, precarious, and constricted universe of international thought, action, and possibility. Subscribing to such a binary opposition establishes a global template that procures synthetic yet volatile standards of a simplified universe of right and wrong.

\footnotetext{
${ }^{29}$ See Michael Klare, Rouge States \& Nuclear Outlaws: America's Search for a New Foreign Policy (New York: Hill and Wang, 1995); Thomas H. Henriksen, "The Rise and Decline of Rogue States," Journal of International Affairs 54.2, (Spring 2001) 349-373; Raymond Tanter, Rogue Regimes: Terrorism \& Proliferation (New York: St. Martin's Press, 1998); Robert S. Litwak, Rogue States and US Foreign Policy: Containment After the Cold War (Baltimore: Johns Hopkins University Press, 2000); Noam Chomsky, Rogue States: The Rule of Force in World Affairs (Cambridge: South End Press, 2000); Clyde Prestowitz, Rogue Nation: American Unilateralism \& the Failure of Good Intentions (New York: Basic Books, 2003); T. D. Allman, Rogue State: America at War With the World (New York: Nation, 2004).

${ }^{30}$ George W. Bush, speech, The Citadel, Charleston, South Carolina, 23 Sept. 1999, The George W. Bush Foreign Policy Reader: Presidential Speeches With Commentary, ed. John W. Dietrich (New York: M.E. Sharpe, 2005) 22.
} 
The "rogue state" is an epistemic category that is part of the antiquated bipolar global security context, yet it has been reconfigured, resurrected by the event of $9 / 11$. The concept of the rogue state, introduced during the Clinton administration (1992-2000), is "peculiarly American" (F. Cameron). "Although the 'rogues' are all authoritarian states, there are substantial differences between their political systems and their degree of hostility toward the US. Yet [the US] maintains a single policy toward the 'rogues' based on a mix of political and economic sanctions, international non-proliferation regimes, and punitive military action."31 The category presently refers to those states that overtly "threaten" global peace and freedom by supporting terror and seeking to acquire WMD. The leap from "threat," to "threat to US," to "threat to global order/society" is axiomatic under the US ASA. Overt criteria that merit the imposition of the label rogue state are: being non-democratic and authoritarian, commission of "gross" violations of human rights, and engaging in unwarranted militarization. ${ }^{32}$ The application of these criteria is selective; for instance, present US allies such as Saudi Arabia, Kuwait, Oman, and Jordan are non-democratic, authoritarian, engage in "gross" violations of human rights, and/or possess large militaries. ${ }^{33}$ The US $A S A$, with its moralistic, ethical, militaristic, and unfettered pursuit of absolute security, has enabled the US to be the sole arbiter in

\footnotetext{
${ }^{31}$ Cameron 142.

${ }^{32}$ See International Security Research Group, ISRG Nuclear Proliferation Dossier: Rogue States, 11 Nov. 2007 $<$ http://www. security-research.at/proliferation/?page_id=2>; George W. Bush, "Prevent Our Enemies From Threatening Us, Our Allies, and Our Friends with Weapons of Mass Destruction," The National Security Strategy of the United States of America 2002, Washington, D.C., The White House, 2002, 11 Nov. 2007 $<$ http://www. whitehouse.gov/nsc/nss5.html $>$.

${ }^{33}$ See Parker T. Hart, Saudi Arabia and the United States: Birth of a Security Partnership (Bloomington: Indiana University Press, 1998); Michael Herb, All in the Family: Absolutism, Revolution, and Democratic Prospects in the Middle Eastern Monarchies (Albany: State University of New York Press, 1999).
} 
determining when a state is rogue, despite empirical criteria. Toward the end of the Clinton administration, "rogue state" was replaced with "state of concern." In a unipolar world, the more forceful category of rogue state has been reintroduced. After $9 / 11$, the category came to include sponsoring terrorism and proliferation of WMD; the threat posed by rogue states unequivocally justifies an absolutist, unipolar security policy. ${ }^{34}$ While terrorist organizations will continue to seek a WMD capability independent of state programs, the sophisticated WMD knowledge and resources of a state could enable a terrorist capability. State sponsors of terrorism and all nations that fail to live up to their international obligations deserve greater scrutiny as potential facilitators of WMD terrorism. $^{35}$

Select states that have complied with US mandates have been removed from the list. During the late 1990s, North Korea, Pakistan, Iraq, Iran, Afghanistan, Libya, Syria, Cuba, and Sudan were rogue states. The US-Pakistani alliance following the $9 / 11$ attacks effectively removed Pakistan from the list, as did the US invasions of Afghanistan and Iraq after the 9/11 attacks. Libya is working toward removal by falling into line with US global security policy, for example, by formally renouncing WMD. In general, the remaining rogue states have been officially branded as being part of an ominous "axis of evil. ${ }^{36}$ In the State of the Union Address 2002, US President George W. Bush declared

\footnotetext{
${ }^{34}$ See International Security Research Group, ISRG Nuclear Proliferation Dossier: Rogue States, 11 Nov. 2007 $<$ http://www.security-research.at/proliferation/?page_id=2>.

${ }^{35}$ US Department of State, Country Reports on Terrorism, Office of the Coordinator for Counterterrorism 28 April 2006, Chp. 7 The Global Challenge of WMD Terrorism, 15 May $2007<$ www.state.gov/s/ct/rls/crt/2005/64660.htm>.

${ }^{36}$ See Bruce Cummings, Ervand Abrahamian, and Moshe Ma'oz, eds., Inventing the Axis of Evil: The Truth About North Korea, Iran, and Syria (New York: New Press, 2004); Hugh Brogan, The Penguin History of the United States of America (London: Penguin Books, 1990); Graham Fuller, Islamic Fundamentalism in Pakistan: Its Character \& Prospects (Santa Monica: RAND Corporation, 1991), 31 May $2007<\mathrm{http}: / /$ www.rand.org/pubs/authors/f/fuller_graha m.html>.
} 
that the US views rogue "states, and their terrorist allies, [as constituting] an axis of evil, arming to threaten the peace of the world." ${ }^{37}$ Select "communist," hyper-nationalist, and "radical" Islamic state ideologies are viewed as posing direct ideational and material threats to the US National Security State's global leadership, security policy, and weal of global society. A preponderance of US power, in conjunction with unipolarity, a ubiquitous security discourse based on moral and ethical considerations, and intense enmity toward rogue states, drives post-9/11 global security policy. "Without enemies ... a nation [is] without purpose and direction. The various components of the [US] National Security State need enemies to justify their ... budgets, to aggrandize their work ... to give themselves a mission in the aftermath of the Soviet Union; ultimately, to reinvent themselves." ${ }^{38}$ The rogue state category has thus been reconfigured to reflect an absolutist, unipolar framework, and without the ballast of the USSR the US has free reign to determine what types of states pose a threat to the world community.

In positing an enemy, it is interesting to note that judgment is being passed by the unipolar power pertaining to a state's essential right to exist. Yet, judgment is a practice that occurs without objective criteria. That is, power judges "without criteria. We are in the position of Aristotle's prudent individual, who makes judgments about the just and unjust without the least [objective] criterion." ${ }^{39}$ The political and moral dimensions of judgment are based on subjective and relative precepts that have no intrinsic correctness

\footnotetext{
${ }^{37}$ George W. Bush, State of the Union Address 2002, 29 Jan. 2002 (Washington, D.C.: The White House); John W. Dietrich, ed., The George W. Bush Foreign Policy Reader: Presidential Speeches With Commentary (New York: M. E. Sharpe, 2005) 59-62.

${ }^{38}$ William Blum, Rogue State: A Guide to the World's Only Superpower (Monroe: Common Courage Press 2000) 15.

${ }^{39}$ Jean Francois Lyotard and Jean-Loup Thebaud, Just Gaming, trans. Wlad Godzich (Minneapolis: University of Minnesota Press, 1999) 14.
} 
or validity beyond the precepts themselves. Every political judgment modifies the "facts" on which it is passed; judgment, while devoid of objective criteria per se, is a form of political thought that is itself a form of political action. ${ }^{40}$ Indeed, while one may dispute an empirical fact, it is impossible to dispute the motives and intentions that underlie the interpretation of a fact. A fact has significance based on who or what is interpreting. Judgment is therefore an act of imagination, enabling an actor to have the power to invent criteria for "objective" judgment. ${ }^{41}$ To have criteria for "true" objective judgment would assume, as the US $A S A$ does, that there is an objective consensus that can be obtained between US security, global security, and peace, freedom, and justice. The event of $9 / 11$ has provided a means for the US to pursue such a course of action. Yet, to put forward a singular framework that determines what constitutes global security involves establishing truths with core principles that are, in actuality, malleable and illimitable. In the case of rogue states,

the US is exquisitely attuned to the rise of a government, that will not lie down and happily become an American client state, that will not look upon the free market or the privatization of the world known as 'globalization' as the summum bonum, that will not change its domestic laws and public policies to favor foreign investment at the expense of the poor, that will not be unconcerned about the effects of foreign investment upon the long-term welfare of its own people, that will not easily tolerate the decrees of the IMF, USAID, or the US war on terror and the militarization of law enforcement, or the WTO, that will not allow an American or NATO military presence/installation upon its soil. $^{42}$

\footnotetext{
${ }^{40}$ See Carr, Twenty 1-10.

${ }^{41}$ Lyotard, Gaming 17-18.

${ }^{42}$ Blum 23.
} 
The US $A S A$ aggressively promotes state-specific conceptual and moral systems that, in turn, inform the US postulation of security. ${ }^{43}$ As stated by US President George W. Bush, the Evil "Empire has passed, but evil remains ... our nation is on the right side of history — the side of man's dignity and God's justice ... The vacuum left by America's retreat would invite challenges to our power. And the result, in the long run, would be a stagnant America and a savage world." 44

When considering the US $A S A$, one must keep in mind that "categories express not only the forms but also the conditions of existence ... The truth [embodied in categories] is not 'detached ... like a finished article from the instrument that shapes it." "45 The process of conceptual and material "production" of security is part of a larger enterprise of obtaining "absolute security." state's total exercise of control over the classification of action taken against threats to security-with "threat" being so vague and expansive that implementing security becomes a destabilizing as well as totalizing affair. The US is able to justifiably assume this posture because of the war response the US has articulated to $9 / 11$ based on intangible and un-falsifiable jingoistic, moral, and ethical considerations. The US $A S A$ (especially the war on terror) is hyper-nationalist in thought and practice-perhaps even more so than the rogue states that have been designated enemies of global order. Fervent

\footnotetext{
${ }^{43}$ See Helen Milner and Jack Snyder, "Lost Hegemony?" International Organization 42.4 (Fall 1988) 749-750.

${ }^{44}$ George W. Bush, speech, The Ronald Reagan Presidential Library, Simi Valley, California, 19 Nov. 1999, The George W. Bush Foreign Policy Reader: Presidential Speeches With Commentary, ed. John W. Dietrich (New York: M. E. Sharpe, 2005) 26-27.

${ }^{45}$ Guy Debord, The Society of the Spectacle, trans. Donald Nicholson-Smith (New York: Zone Books, 1995) 144.

${ }^{46}$ See David C. Hendrickson, "Toward Universal Empire: The Dangerous Quest for Absolute Security," World Policy Journal 19.3 (Fall 2002) 1-3.
} 
belief in ideals, forms, and practices of US political, social, and economic thought undergird the vanguard role of the US on the world stage. Hyper-nationalism, however, negatively impacts the rational material self-interest of states, particularly because nationalism is a precursor of imperialism: "wars, begun for motives of security ... become wars of aggression and self-seeking."47

Destabilizing the States System

This study contends that the US $A S A$, premised on a preponderance of power, produces insecurity, instability, and generates enduring threats to US national and global security by fomenting conflict and instability by ignoring the principle of state sovereignty. In practice, the $A S A$ alienates and isolates, foments distrust, discord, and undermines cooperative incentives or inclinations amongst states within a system of states. This occurs because the US $A S A$ empties fundamental states system concepts of substantive content while retaining the language and form of such concepts. In defining enemies of global peace and freedom, the US ASA is specular in nature, that is, it designates certain states as viable enemies that in actuality pose little or no genuine threat.

Image opposed to substance informs the unilateral postulation of rogues. Terror in particular has provided the impetus for an unbridled US $A S A$. This is the case because

what stays with us, above all else, is the sight of images, and their fascination, are necessarily what we retain, since images

\footnotetext{
${ }^{47}$ E. H. Carr, "Realism and Idealism," Conflict After the Cold War: Arguments on Causes of War \& Peace $2^{\text {nd }}$ ed., ed. Richard K. Betts (New York: Pearson, 2005) 77; Einstein 3.
} 
are, whether we like it or not, our primal scene. And, at the same time as they have radicalized the world situation, the events in New York can also be said to have radicalized the relation of the image to reality ... The role of images is highly ambiguous. For, at the same time as they exalt the event, they also take it hostage. They serve to multiply it to infinity and, at the same time, they are a diversion and a neutralization ... The image consumes the event, in the sense that it absorbs it and offers it for consumption ... [giving] it unprecedented impact in imposing a single framework for international security policy. ${ }^{48}$

The spectacle of terror, beyond the actual event, exclusive of the other's perspective as to motive, justification, and the role assumed by the US in perpetuating terror, is utilized to effectuate homogenization of the states system. The US has been able to effectively package its $A S A$ as a necessary and indubitable response to the wanton $9 / 11$ attacks on the US homeland based on hatred, iniquity, jealousy, and other intangible moralistic criteria. One cannot argue with a position rooted in morality because of the fundamental distinction that exists between a fact and an interpretation, between moral, factual, and material elements. The fact of the actual attacks is undeniable; the meaning, significance, and interpretation of the fact, however, is boundless, and the US seeks to privilege its interpretation as the only interpretation that can be possibly extracted from the event of 9/11, an interpretation that embodies an objective world view:

In all its specific manifestations ... the spectacle epitomizes the prevailing node of [security] ... In form and content the spectacle serves as total justification for the conditions and aims of the existing system. It further ensures the permanent presence of that justification. ${ }^{49}$

\footnotetext{
${ }^{48}$ Jean Baudrillard, The Spirit of Terrorism \& Requiem for the Twin Towers, trans. Chris Turner (London/New York: Verso, 2002) 26-27.

${ }^{49}$ Debord 12-13.
} 
To retain the rogue state category is to provide justification for the US $A S A$. To topple régimes without a semblance of legitimacy is to risk using what the states system would term an "illegitimate" use of force. Unipolarity does not explicitly equal absolutism in the context of a states system, so hegemonic warfare is waged in overt and subtle ways. Without "just" cause, the US cannot simply outright discard the system of states' precepts of sovereignty in its dealings with (rogue) states; indeed, the invasions of lraq and Afghanistan have attenuated US credibility and status in some parts of the world community. This would wholly empty the states system of validity. The US cannot simply discard world opinion in total; to do so would result in a total paradigm shift, and complete abandonment of a states system. Hence, the event of $9 / 11$ has been utilized as a means to explicitly bypass the restraints placed upon states by the states system.

Global security now hinges on terror. Due to the $9 / 11$ attacks, terror, a polymorphous category with inexhaustible application as far as what constitutes a terrorist act or thought, is the standard for global security. US interests and priorities set the parameters for global security policy, and by default the agenda for the international community. Since US policy stipulates that, "globalization requires that partner nations work together closely to prevent, detect, and disrupt linkages that may develop between terrorists and [any type of] facilitators," states that cannot counter US power are pushed into accommodating its $A S A .{ }^{50}$ To ascertain the operative premises and consequences of the US $A S A$ and its relationship to the event of $9 / 11$ the following general questions will be addressed: How does US domestic security, in light of unipolarity, affect/effect global

\footnotetext{
${ }^{50}$ US Department of State, Country Reports on Terrorism, Office of the Coordinator for Counterterrorism 28 April 2006, Chapter 7 The Global Challenge of WMD Terrorism, 21 May $2007<\mathrm{www}$.state.gov/s/ct/rls/crt/2005/64660.h $\mathrm{tm}>$.
} 
security? How has global securitization changed in a post-9/11 world? What role does US power assume? How is US power resisted, and what does resistance signify?

While a "politics of resistance" versus a "politics of supremacy" was an explicit theme in the previous bipolar paradigm, in a post-9/11 unipolar world the US has attempted to restructure notions of resistance and supremacy along very distinct yet broad cultural, ideological, social, moral, and political lines. ${ }^{51}$ The US $A S A$ actively and forcibly proffers the politics, culture, and morality of a single state to objectively represent the will and wellbeing of every state, in spite of the Westphalia principle of diverse sovereign states. The Westphalia system has (traditionally) been viewed as providing the following key principles/cornerstones of modern international relations: sovereignty of states, elementary right of political self-determination, functional equality between states, and non-intervention in the internal affairs of states. ${ }^{52}$

\section{US Imperialism \& Hegemony}

The post-9/11 $A S A$, though distinct from the Cold War and pre-9/11 security contexts, is part of a historical trajectory of the external projection of US power that has selectively jettisoned Westphalia principles. Generally speaking, US foreign and security policy have been informed by what Georges Debord describes as an aspiration to "refashion the totality of [international] space into its own peculiar décor." $"$ Indeed, an embryonic form of imperialistic/hegemonic security was put into practice by the US as

\footnotetext{
51 Gill 68-73; Samuel P. Huntington, "The Clash of Civilizations?" Foreign Affairs 72.3 (Summer 1993).

${ }^{52}$ Treaty of Westphalia, October 24, 1648: Peace Treaty Between the Holy Roman Emperor, the King of France \& Their Respective Allies, Avalon Project, Yale Law School 1996, 12 July $2007<$ www.yale.edu/lawweb/avalon/westphal htm>.

${ }^{53}$ Debord 121.
} 
early as 1898 , when it involved itself in the Spanish-Cuban war of independence. Over a century later, the US has steadily pursued the hegemonic project it embarked on after WWII when it established the global rules of engagement with the USSR, militarizing the US economy to counter the ominous "Soviet threat" to US and global security. ${ }^{54}$ In the $21^{\text {st }}$ century, the US faces no overwhelming opposition to its unilateralist security policies, and has premised its security on a war response to the $9 / 11$ attacks on the US Homeland. 9/11 has enabled the US to assume its paladin role with verve, determination, and indubitable legitimacy. This, supposedly, is a good thing, a positive product of the "end of history." 55 As US President G.H. Bush declared in the aftermath of the collapse of communism, a "world once divided into two armed camps now recognizes one sole and preeminent power, the USA. And they regard this with no dread. For the world trusts us with power, and the world is right." ${ }^{, 56}$ The US international agenda, inextricably linked with its domestic interests, has and continues to be held out as the basis for defining the will and interests of the international community.

The "will of the international community," however, in security policy/discourse explicitly refers to the will of the US. The vague notion of the "will of the international community" functions in much the same manner as "the People" in US domestic political discourse. Multifarious warfare is waged by the US in the name and interests of "the People" and the "will of the international community." Yet "the People," like the "will

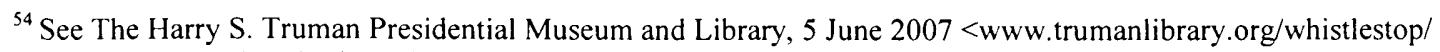
study_collectionsdoctrine/large/index.php>.

${ }^{55}$ See Francis Fukuyama, "The End of History?" The National Interest 16 (Summer 1989); Robert J. Lieber, "Foreign Policy and American Primacy," Eagle Rules? Foreign Policy and American Primacy in the $21^{\text {st }}$ Century, ed. Robert J. Lieber (Upper Saddle River: Prentice Hall, 2002) 1-15.

${ }^{56}$ George H. Bush, New York Times, 29 Jan. 1992, A-16; William Bium, Rogue State: A Guide to the World's Only Superpower (Monroe: Common Courage Press, 2000).
} 
of the international community," is a functional sociopolitical construct, contingent upon subjective and relative values and interests. As Barbara Herrnstein Smith observes, "All value is radically contingent, being neither a fixed attribute, an inherent quality, or an objective property of things but, rather, an effect of multiple, continuously changing, and continuously interacting variables." ${ }^{, 57}$

A war on terror, waged in the interests of the "international community," consists of the following components:

1., making the world open and hospitable for-in current terminology-globalization, particularly US-based transnational corporations, 2., preventing the rise of any society that might serve as an alternative to the US moral, political, social, ideological, and economic model, and 3., extending political, economic, and military hegemony over as much of the globe as possible to prevent the rise of any regional power that might challenge US supremacy, creating a global order in the US image, as befits the world's only superpower. ${ }^{58}$

To be hegemonic, US security must consist of ubiquitous, objective precepts as the only legitimate, authoritative components that can constitute the fabric of global security and society. ${ }^{59}$ The moral justification to utilize an unfettered use of force to obtain US security goals is therefore postulated as intrinsically correct under its $A S A$, in light of the 9/11 attacks. Russian President Vladimir Putin, however, has observed the negative

\footnotetext{
${ }^{57}$ Barbara Herrnstein Smith, "Contingencies of Value," The Norton Anthology of Theory and Criticism, eds. Vincent B. Leitch, William E. Cain, Laurie A. Fink, Barbara E. Johnson, John McGowan, and Jeffery J. Williams (New York: W.W. Norton, 2001) 1913.

${ }^{58}$ Blum, Rogue 13-14.

${ }^{59}$ See Fukuyama, "History" for an example of liberal-democracy touted as the final stage of political evolution for humankind. For a discussion of grand strategies in securitization measures see B. R. Posen The Sources of Military Doctrine: France, Britain and Germany Between the World Wars (Ithaca: Cornell University Press, 1984).
} 
effects of this premise, pointing out that US security policy is directly contributing to fueling a global arms race and proliferation. The world is

witnessing an almost unconstrained hyper use of force in international relations. One state, the US, has overstepped its national borders in every way ... This is very dangerous. Nobody feels secure anymore because nobody can rely upon mechanisms of order such as international law ... A unipolar system is nourishing an arms race with the desire of countries to get nuclear weapons ... Until we dispense with unilateralism in international affairs, until we exclude the possibility of unfettered imposition of one country's views on others, we will not have stability. ${ }^{60}$

When considering the US $A S A$, it is important to keep in mind Arnold Wolfers' observation that "political formulas such as 'national interest' or 'national security' ... need to be scrutinized with particular care ... While appearing to offer guidance and a basis for broad consensus they may be permitting [one state] to label whatever policy [it] favors" as universal. ${ }^{61}$ The US ASA promises fortification, management, order, peace, and security through totalizing control of world affairs based on US moral prerogatives. This state of affairs produces a rubric of security that, based on moralistic and ethical justifications imbued in a hostile war response, creates a precarious state of affairs for the conduct of international relations. Indeed, $9 / 11$ has become an objective "fact" that provides blanket authority and immunity for implementing an absolutist security agenda. Under the US $A S A$, the "borderline between culture, [ideology,] and empirical reality

\footnotetext{
${ }^{60}$ Vladimir Putin, speech, " $43^{\text {rd }}$ Munich Security Conference," 10 Feb. 2007, BBC News Online, 1 June $2007<$ http:// news.bbc.co.uk/2/hi/europe/6349287.stm>.

${ }^{61}$ Arnold Wolfers, "National Security as an Ambiguous Symbol," Political Science Quarterly 67 (Dec. 1952) 481-502.
} 
becomes more and more indistinct." ${ }^{92}$ According to Wolfers' notion of a "normative proposition," nations "are called upon to give priority to national security and thus to consent to any sacrifice of value which will provide an additional increment of security ... Pushed to its logical conclusion ... spatial extension of the range of values does not stop short of world domination., ${ }^{, 3}$

Security is defined by complex systemic order-combines that manufacture, deploy, reproduce, reify, and create "a continuous call for authority" 64 against internal and external threats. ${ }^{65}$ Security, as with any other expression of power, is a discursive as well as material form of truth, given that individuals and collectivities are products of power, of specific configurations of order that utilize security to maintain modalities of control. US innocence (no-ill will toward other states), benevolence (the desire to do good for other states), and exceptionalism (the superiority of the US to establish global order) justify the globalization of US values and security interests, especially in a post$9 / 11$ context. $^{66}$ Yet, a unipolar and absolutist security system is destabilizing vis-à-vis a system of states. In light of security, state policy, and the relationship each has with imperialism, Arnold Wolfers notes that,

every increment of security must be paid by additional sacrifices of other values usually of a kind more exacting than the mere

\footnotetext{
${ }^{62}$ Theodore W. Adorno, The Culture Industry: Selected Essays on Mass Culture, ed. and intro. J.M. Bernstein (New York: Routledge, 1991) 61 .

${ }^{63}$ Wolfers, "National" 119.

${ }^{64}$ Michael Hardt and Antonio Negri, Empire (Cambridge: Harvard University Press, 2000) 14.

${ }^{65}$ Howard K. Bloom, The Lucifer Principle (New York: Atlantic Monthly Press, 1995) 1-25.

${ }^{66}$ Jerel A. Rosati, The Politics of US Foreign Policy $2^{\text {nd }}$ ed. (Fort Wnrth: Harcourt Brace, 1999) 400-410; Jerel A. Rosati, ed., Readings in the Politics of US Foreign Policy $2^{\text {nd }}$ ed. (Fort Worth: Harcourt Brace, 1998) $376-386$.
} 
expenditure of precious time on the part of policy makers. At a certain point, then, by something like the economic law of diminishing returns, the gain-if any-in security no longer compensates for the added costs of attaining it. Absolute security is out of the question unless a country is capable of world domination, in which case, however, the insecurities and fears would be internalized and probably magnified. ${ }^{67}$

The US, in assuming an absolutist security posture, stands above and is outside of contending forces. It comprises an authority that is neutral between the conflict that permeates state relations and the international system. The righteousness of the US enables it in "every case to decide which party to the dispute has justice on its side." 68 As Special Assistant for US National Security, Condoleezza Rice unequivocally declared: "American values are universal ... the triumph of these values is most assuredly easier when the international balance of power favors those who believe in them." 99

Global Enemies, Militarization \& Ideology

The US $A S A$ embodies "supreme ideological representation." That is, the US is tendered as a means of universal unification, a unity that is "real" in a material, political, cultural, moral, and psychological sense in light of the ominous threat posed by terror to all actors in the international system after 9/11. The "International Communist Conspiracy" that justified and legitimated US security during the Cold War has been replaced by a polymorphous war on terror waged against any idea, practice, state, regime,

\footnotetext{
${ }^{67}$ Wolfers, "National" 120.

${ }^{68}$ Michel Foucault, Power: Essential Works of Foucault, 1954-1984, Vol. III, trans. Robert Hurley, intro. Colin Gordon, ed. James D. Faubion (New York: New Press, 1994) 27.

${ }^{69}$ Condoleezza Rice, "Promoting the National Interest," Foreign Affairs 79.1 (Jan/Feb 2000) 49.
} 
person, and/or group that proactively and aggressively oppose US power. When material and intangible power are concentrated, however, destabilization and insecurity become pronounced. "The more concentrated the system becomes globally, ultimately forming one single network, the more it becomes vulnerable... [In the case of 9/11] it was eighteen suicide attackers who ... unleashed a global catastrophic process., ${ }^{70}$

The form and substance of post-9/11 US security are beyond critique, or can only be critiqued, analyzed, expounded upon, etc., on their own terms. Hence, the US can discuss the "proper" parameters of international security via its ordering constructs such as ideology, political philosophy and system, and economic policy. The exercise of US power on the world stage contributes to the creation and propagation of new objects of "knowledge and accumulates new bodies of information. Knowledge and power are integrated with one another ... It is not possible for power to be exercised without knowledge, and it is impossible for knowledge not to engender power." ${ }^{\text {71 }}$ The institutionalization of knowledge/power, in the guise of authoritative, objective security discourse, systemically and systematically privileges a particular system of truth over others. Institutionalized US power in the form of global governmental and nongovernmental actors reflects a rationalized administration of knowledge - an "administration of knowledge, a politics of knowledge, relations of power which pass via knowledge." 72 In the manufacture of power-precepts, it is important to keep in mind what type(s) of knowledge does an actor that wields supreme authority seek to

\footnotetext{
${ }^{70}$ Jean Baudrillard, The Spirit of Terrorism \& Requiem for the Twin Towers, trans. Chris Turner (London/New York: Verso, 2002) 8 .

${ }^{71}$ Foucault, Power 51-52.

${ }^{72}$ Foucault, Power 69.
} 
disqualify? "Which speaking, discoursing subjects-which subjects of experience and knowledge-do you then want to diminish?",73 Who has "justice" on their side and why?

Military objectives such as destroying the al Qaida network have been combined with "globalist objectives, such as making the war [on terror] an ideological crusade "for a just peace - a peace that favors human liberty' [via] rebuilding Afghanistan with proUS leaders, and securing access to oil ... winning the war on terrorism is a uniquely America's 'responsibility' equally for idealistic and power-political reasons." ${ }^{, 44}$ Indeed, it is the case that

only the US can rally the world in a task of this complexity ... against an enemy so elusive and so resourceful. [Only] the US can see this effort through to victory. This responsibility did not come to us by chance. We are in a unique position because of our unique assets ... the character of our people, the strength of our ideals, the might of our military. ${ }^{75}$

The production of knowledge and truth is, therefore, essential to the manufacture and deployment of US security. Hence, $9 / 11$ the event has been converted to 9/11-asspectacle, 9/11-as-legitimizer, 9/11-as-the-moral-and-ethical, 9/11-as-the-referencepoint for US security policy. Truth, an elusive and malleable state of affairs, is not independent of power and control. Indeed, truth's effect on the unthinking, uncritical subject leads to what Nietzsche refers to as humankind's most false illusion, that is, "a thing exists therefore it is legitimate. Here one is concluding functionality from viability,

\footnotetext{
${ }^{73}$ Foucault, Power 85.

${ }^{74}$ Gurtov, Confronting 1-20.

${ }^{75}$ Dick Cheney, speech before the Council on Foreign Relations, 15 Feb. 2002, New York Times, 16 Feb. 2002 , A-6.
} 
and legitimacy from functionality." 76 The manufacture of knowledge and truth "is a political production as for political power; it is the object, under diverse forms, of immense diffusion and consumption ... it is produced and transmitted under the control, dominant if not exclusive, of a few great political and economic apparatuses." 77

The language and content of absolutist security, which expresses the "total practice of one particular economic and [sociopolitical] formation," cannot be challenged because it is based on the event of $9 / 11 ; 9 / 11$ is, so to speak, the formation's agenda. ${ }^{78}$ Yet, at the root of unipolar security lies the specialization and specification of US power. US power is so pronounced that it asserts the right to change the meaning of a cornerstone of international relations under the aegis of security. Sovereignty is key concept that has been attenuated by the US $A S A$. According to the US State Department's Director of Policy Planning, Richard Haass,

Sovereignty entails obligations. One is ... not to support terrorism in any way. If a government fails to meet these obligations, then it forfeits some of the normal advantages of sovereignty, including the right to be left alone in your own territory. Other governments, including the US, gain the right to intervene. In the case of terrorism, this can even lead to a right of preventive, or preemptory, self-defense. ${ }^{79}$

\footnotetext{
${ }^{76}$ Friedrich Nietzsche, "On Truth and Lying in a Non-Moral Sense," The Norton Anthology of Theory and Criticism, eds. Vincent B. Leitch, William E. Cain, Laurie A. Fink, Barbara E. Johnson, John McGowan, and Jeffery J. Williams (New York: W.W. Norton, 2001) 878.

${ }^{77}$ Foucault, Power 132.

${ }^{78}$ Debord 15.

${ }^{79}$ Richard Haass quoted in Mel Gurtov, "American Crusades: Unilateralism, Past \& Present," Confronting the Bush Doctrine: Critical Views From the Asia-Pacific, eds., Mel Gurtov and Peter Van Ness (London: Routledge-Curzon, 2005) 11.
} 
By attenuating sovereignty, the US arrogates to itself the right to intervene, to strike at any threat it feels may be the case. "The specialized role played by the [US and its security] is that of spokesman for all other activities, a sort of diplomatic representative of hierarchical society at its own court, and the source of the only discourse which [global] society [is] allow[ed] to hear." 80 To define the problem of security for the entire globe as being rooted in amorphous terror is to reduce the complexity of a system of states and its attributes (for example, sovereignty, cooperation, diplomacy, economy, balance of power, interest, interdependence) to a "simplistic" formula based on a single state's policy, interests, morals, and values. ${ }^{81}$

Morality, ideology, and militarization go hand in hand under the US $A S A$. For example, from 1995-2000 the US share of world military expenditures was $37 \%$ more than the combination of military spending by the other nine countries in the top ten of states who spent the most on militarization: US arms sales amounted to over $\$ 18$ billion in 2000 , and by 2003 the US spent over $\$ 400$ billion. $^{82}$ An exceptional and unprecedented military build-up, in conjunction with the mass dissemination of ideology and morality, has been initiated since the $9 / 11$ attacks in order to secure the US's preeminent and unipolar position in the global order.

The claims of ideology now take on a sort of flat, positivistic exactness: ideology is no longer a historical choice, but simply an assertion of the obvious. Names of particular ideologies have vanished. The portion of properly ideological labor serving the system may no longer be conceived of other than in terms of an

\footnotetext{
${ }^{80}$ Debord 18-19.

${ }^{81}$ Suzanne Daley, "French Minister Calls US Policy Simplistic," New York Times, 7 Feb. 2002, A-10.

${ }^{82}$ See SIPRI, 5 May 2007 <http://projects.sipri.se/milex/mex_major_spend ers.html>.
} 
'epistemological base' supposedly transcending all specific ideological phenomena. Ideology in material form is itself without a name ... 'Total ideology'-the despotism of a fragment imposing itself as the pseudo-knowledge of a ... whole, as a [totalizing] worldview-forms the basis of post-9/11 security. ${ }^{83}$

\section{Morality \& Global Governance}

There is then a battle for truth, around the circumference of truth, where war is waged not on behalf of the truth, but over the power and "status of truth and the economic and political role it plays." ${ }^{84}$ The war on terror, the progeny of $9 / 11$, as a security rubric creates a binary framework of US/international society versus enemies of peace and freedom. A state can find itself locked into a specified category, limiting or expanding its potential and possibilities within the global context. Pakistan, for example, is an example of a state that fell into favor with US security policy despite its domestic politics, acquirement of WMD, sale of WMD technologies to official enemies of the US

(North Korea), and a history of providing support for terrorist groups. Requiring Pakistan's cooperation in the war on terror, the US provided material incentives to a state that had been classified as a viable threat.

Sanctions on Pakistan for its nuclear-weapons tests in 1998 were removed; its government, well known for cooperation, received $\$ 600$ million in aid, an open door to IMF assistance ( $\$ 135$ million), and access to the F-16 jet fighters that it had bought from the US but had been denied the right to possess. Musharraf, while cracking down on allegedly radical Islamic

\footnotetext{
${ }^{83}$ Debord 212-213.

${ }^{84}$ Foucault, Power 132.
} 
schools and groups in his country, used the opportunity afford by the war [on terror] to cement his [authoritarian] rule. ${ }^{85}$

Consistency in global security policy is tied to the moral and political dimensions of US security. These dimensions, in turn, "are determined by the [US] political and cultural environment. Power may comprise anything that establishes and maintains the control of man over man." ${ }^{, 86}$ Politics, morality, and security are explicitly moral in their enunciations and manifestations. By postulating a universal moral enemy, one is able to establish cognitive consistency and premise action on the defeat of an objectively true "clear and present danger" that is truly beyond question. Indeed, by "abolishing the dictators, ... militarists, manufacturers of armaments or one of the other villains, peace [will] be preserved ... it is often the passion for the antidote- whether [eliminating terror, establishing] democracy, ... or [pushing] free trade-rather than an analysis of the illness" that motivates the moral and military impetus behind waging war. ${ }^{87}$ Universal moral principles, however, cannot be wholly applied to the actions of every state since morality is "filtered through the concrete circumstances of time and place." ${ }^{.88}$ Security is not an objective category of truth. Rather, it is indicative of relations of power, dominance, and subordination. Morality is relative, non-objective in character and content. While a clash of aims, interests, moralities, or civilizations may be intrinsically

\footnotetext{
${ }^{85}$ Gurtov 16-17.

${ }^{86}$ Hans J. Morgenthau. Politics Among Nations: The Struggle for Power \& Peace $4^{\text {th }}$ ed. (New York: Alfred Knopf, 1966) 11.

${ }^{87}$ Geoffrey Blainey, "Power, Culprits, and Arms," Conflict After the Cold War: Arguments on Causes of War \& Peace $2^{\text {nd }}$ ed., ed. Richard K. Betts (New York: Pearson-Longman, 2005) 112-113.

${ }^{88}$ Morgenthau 12.
} 
satisfying, "aims are simply varieties of power. The vanity of nationalism, the will to spread an ideology ... the desire for more territory or commerce, the avenging of defeat or insult, the craving for greater national strength or independence, the wish to impress or cement alliances-all these represent power in different wrappings." 89 The war on terror is interesting because it is a "war in which the enemy is criminalized if he simply defends himself" or seeks the means to effectively defend against perceived US aggression. ${ }^{90}$ Hence, North Korea's defensive posture can be readily construed as belligerent, even though each state has a supposed right to self-determination and self-defense.

$9 / 11$ is indicative of the fact that terror is mutually exclusive from the target of terrorism, that is, the US and its allies. Under a terror-rubric, there exists the vanguard and paladin of justice, peace, and freedom (the US), and those "unlawful combatants criminally resisting the forces of universal order." 91 Terror and warfare, however, do not occur in a vacuum; "War is never an isolated act; War does not spring up suddenly, it does not spread to the full in a moment." ${ }^{, 92}$ Terror therefore provides a malleable security template that establishes a "domain of free syntheses" where everything and anything can be securitized..$^{93}$ The parameters of terror are only limited by the hegemonic imagination.

The "positive" programmatic of patriotism, loyalty, and fidelity, and the opprobrium attached to contradiction, critical appraisal, and divergent views from the

\footnotetext{
${ }^{89}$ Blainey, "Power" 114.

${ }^{90}$ Zizek 93.

${ }^{91}$ Zizek 93.

${ }^{92}$ Carl M. Von Clausewitz, On War, ed. and intro. Anatol Rapoport (New York: Penguin, 1982) 106.

${ }^{93}$ Gilles Deleuze and Felix Guattari, Anti-Oedipus: Capitalism and Schizophrenia, trans. Robert Hurley, Mark Seem, and Helen R. Lane, preface Michel Foucault (Minneapolis: University of Minnesota Press, 2003 ) 54.
} 
official line of the unipolar state, embody the present US security agenda. ldeological warfare is rooted in the political-and politics is a fluid and inclusive categorization of action that operates within and gives rise to other concomitant and competing states of affairs (for example, the economic, cultural, and psychological). ${ }^{94}$ Despite the political being the object of war, "it must accommodate itself to the nature of the means, and though changes in these means may involve modification in the political objective, the latter always retains a prior right of consideration." 95 Politics, therefore, is interwoven within war, and exercises a continuous influence upon war and security. "War is not merely a political act, but also a real political instrument, a continuation of political commerce, a carrying out of the same by other means ... for the political view is the object, War is the means, and the means must always include the object in our conception." 96

Rogue states, therefore, serve to legitimate the expansiveness, intrusiveness, essentialness, inexorableness, immanence, and ideological-moral correctness of post-9/11 US security. ${ }^{97}$ As empirical case studies, rogue states reveal that the designation and signifier of "rogue state" has explanatory power in understanding the post-9/11 security context, and how the event of $9 / 11$ has provided fodder for an absolutist security posture.

\footnotetext{
${ }^{94}$ See Adorno 61-97.

${ }^{95}$ Clausewitz 119.

${ }^{96}$ Clausewitz 119

${ }^{97}$ See William Blum, Freeing the World to Death: Essays on the American Empire (Monroe: Common Courage Press, 2005); Nicholas Berry, "The Self-Serving 'Rogue State' Doctrine," Center for Defense Information (Washington, D.C., 2000), 14 Jan. 2007 <www.cdi.org/asia/ fa061600.html>; Mary Caprioli and Peter F. Trumbore, "Identifying 'Rogue' States and Testing their Interstate Conflict Behavior," European Journal of International Relations 9.3 (2003) 377-406, and "Rhetoric Versus Reality: Rogue States in Interstate Conflict," Journal of Conflict Resolution 49.5 (2005) 770-791; Noam Chomsky, Ramsey Clark, and Edward W. Said, Acts of Aggression: Policing Rogue States (New York/London: Seven Stories Press, 1999); Salim Lamrani, ed., Superpower Principles: US Terrorism Against Cuba (Monroe: Common Courage Press, 2005).
} 
US policy toward North Korea in particular is "of a piece with the more profound doctrine shift in US foreign policy that the administration was able to implement with greater ease after the terrorist attacks of September 11, 2001: a move away from traditional containment, a preference for unilateralism over multilateralism, and a scorning of diplomacy in favor of preventive war."98 Rogue states can, therefore, be analyzed on two levels, that is, on a surface level, and on a deeper, substantive level that goes beyond proffered terms. ${ }^{99}$ US policy on its own terms comprises the surface level, which posits objective, apolitical criteria for rogue state status, such as large conventional military forces, state-sponsor-of-terrorism status, illegitimate WMD capacity, and inclusion on the US Country Reports on Terrorism. The Reports articulate US values/interests as the basis for genuine global peace and security; "foremost among criteria for incorporation into the [rogue category is] violation of American ideals."100 For example, although Cuba fails to meet any of the main criteria, it appears in the Reports due to US domestic ideological and political factors.

If one goes beyond the terms of US power, "rogue" states function as any other state would within a states-system context. ${ }^{101}$ Rogue states engage in propaganda, information control, moral, political, and ideological socialization, and seek to acquire resources, armaments, and obtain security. Also, as is the case with other states,

\footnotetext{
${ }^{98}$ John Feffer, North Korea/South Korea: US Policy at a Time of Crisis (New York: Seven Stories, 2003) 14.

${ }^{99}$ See John Feffer, ed., Power Trip (New York: Seven Stories Press, 2003); David Hendrickson, "Toward Universal Empire," World Policy Journal 19.3 (Fall 2002) 1-3.

${ }^{100}$ Raymond Tanter, Rogue Regimes: Terrorism \& Proliferation (New York: St. Martin's Press, 1998) 40-42; William Jefferson Clinton, "Strengthening American Security"; Warren Christopher, "America's Strategy for a Peaceful and Prosperous Asia-Pacific," US Department of State Dispatch v.6, 591-544, 31 July 1995.

${ }^{101}$ See Bruce Cummings, Ervand Abrahamian, and Moshe Ma'oz, eds., Inventing the Axis of Evil: The Truth About North Korea, Iran, and Syria (New York: New Press, 2004).
} 
preservation and projection of power are at the top of rogue state priorities; they seek weapons, funds, resources, and security for the same reason(s) that other states seek them, for example, to protect the integrity of geopolitical borders, preserve political regimes, and project power. ${ }^{102}$ The "rogue" signifier, when viewed outside of US terms, is in actuality part of a more general phenomenon of hyper-nationalism. Rogue status can be viewed as referring to ultra-nationalist states whose socio-political and economic agendas reject the premise of global US power. Indeed, if the US is viewed as a state as opposed to a hegemonic entity, it is as "nationalist" as any other, the difference being that it has the wherewithal to forcibly impose its agenda on a global scale. US Senator Albert Beveridge, at the turn of the century, ardently declared that:

Providence had made [the US] the master organizers of the world to establish system where chaos reigns ... made [the US] adept in government [to] administer government among savage and senile peoples ... has marked the American people as [the] chosen Nation to finally lead in the regeneration of the world. This is the divine mission of America ... We are trustees of the world's progress, guardians of its righteous peace. ${ }^{103}$

The notion that the US has a categorical and legitimate "right" to define the parameters of global affairs has remained a viable component of US foreign policy/discourse since it involved itself in the Spanish-Cuban War for independence in 1898. The US hegemonic impulse has found extensive expression over the last 110 years.

\footnotetext{
102 See Jack S. Levy, "The Offensive/Defensive Balance of Military Technology," Conflict After the Cold H'ar: Arguments on Causes of War \& Peace $2^{\text {nd }}$ ed., ed. Richard K. Betts (New York: Longman. 2002); Scott D. Sagan and Kenneth N. Waltz, The Spread of Nuclear Weapons: A Debate Renewed (New York: Norton, 2003).

${ }^{103}$ Albert Beveridge quoted in William L. Shirer, $20^{\text {th }}$ Century Journey: A Memoir of a Life and the Times-The Start. 1904-1930, l'ol. I (New York: Simon and Shuster, 1976) 68.
} 
Organization of Study

This study will proceed by posing questions and hypotheses, and then discussing conceptual and methodological issues regarding the US $A S A$. Then, the USA Patriot Act 2001 and WMD proliferation vis-à-vis North Korea will be analyzed to expound upon the implementation of the US $A S A$ in a post-9/11 security context. This study will conclude by offering insights and conclusions about the US $A S A$ and its impact on configuring global security. 


\section{CHAPTER 2. QUESTIONS \& HYPOTHESES}

This chapter will clarify the general research questions and hypotheses that ground this study, and will analyze some of the main operative philosophic and theoretic components and assumptions that under-gird the US $A S A$ as template for global security. This will be accomplished by examining in-depth the role, implications, and consequences that epistemology, language, discourse, symbol, morality, and rules of formation play in the articulation and dissemination of global security in a post-9/11 security context. In particular, the US $A S A$ will be analyzed vis-à-vis the event of $9 / 11$, the US war-response to the terrorist attacks, power, force, the war on terror, terrorism, enemies, and select US government statements and policies pertaining to security and terror. Subsequent chapters will then provide empirical exemplars of the US $A S A$ as manifested in the realms of criminalization of terror via the USA Patriot Act 2001, and WMD proliferation by North Korea.

This study will focus upon two specific questions and hypotheses:

Question 1. How is post-9/11 US and global security defined, and has it eclipsed previous notions of security based upon a system of states?

Hypothesis 1. If it is the case that the US is pursuing an $A S A$, then the present global security agenda challenges security notions based on a system of states because an $A S A$ reflects a unipolar world, wherein the values and interests embodied in US security are the basis for global security.

Question 2. Has 9/11 provided an opportunity for the US to implement an absolutist security agenda? 
Hypothesis 2 . If the US is pursuing an absolutist security agenda, then $9 / 11$ has served to legitimate and justify its implementation.

By promulgating an absolutist security discourse, the US has sought to monopolize the conceptual and dialogical capacity of international actors, "capturing" other states in a unipolar security discourse. ${ }^{104}$ This is possible because the event of $9 / 11$ provided the US with an imprimatur of propriety and authority to put forth an absolutist agenda. Clothed in the garb of morality, justice, security, and "unprovoked" attacks on the Homeland, the US has been able to articulate and disseminate an $A S A$ that is premised on a totalizing war-response to $9 / 11$. According to the US National Strategy for Homeland Security 2007, the "terrorist attacks on September 11, 2001, were acts of war against the United States and the principles of freedom, opportunity, and openness that define the American way of life. The severity and magnitude of the attacks were unprecedented, and that dark day became a watershed event in the Nation's approach to protecting and defending the lives and livelihoods of the American people (emphasis added)." 105 As the subsequent discussion will demonstrate, "defending" the lives and livelihoods of the American people involves a moral and ethical notion of security that spills over into every aspect of domestic and international affairs.

The US $A S A$ utilizes techniques of power and control rooted in political realism and in a singular epistemology of security. Four general realist assumptions under-gird the US $A S A$ : unity of action and purpose; facts are objective, value-free concepts;

\footnotetext{
104 See Jean Francois Lyotard, The Postmodern Condition: A Report on Knowledge, trans. Geoff Bennington and Brian Massumi, forward Fredric Jameson (Minneapolis: University of Minnesota Press, 1984); Lyotard, Gaming 1-12.

${ }^{105}$ The White House, National Strategy for Homeland Security October 2007, 19 Aug. $2008<$ http://www. whitehouse. gov/in focus/homeland/nshs/2007/index.html>.
} 
objective laws and regularities exist in the social world; and epistemology produces objective truth. ${ }^{106}$ The US $A S A$ blends these assumptions with raw military power and a knowledge system of security that utilizes epistemic categories to form a seamless, holistic system. So-called "critical" thought is, therefore, useful for gaining further insight into the US $A S A .{ }^{107}$ This is the case because there are "no brute facts, no facts without interpretation, and interpretation always involves theory" that is saturated with inter-subjective values and norms. ${ }^{108}$ Because human cognition is interpretive, "facts" are in actuality context-dependent. There is a general tendency in positivism to regard language as a naming process, a sequence of symbols or words that intrinsically corresponds to that which is named. The US $A S A$ perpetuates itself by emphasizing the axiomatic nature of its ordering principles and categories - for example, terror, peace, freedom, and justice are "organic" signifiers. Such a conceptualization of language

\footnotetext{
${ }^{106}$ See John Mearsheimer, "Back to the Future: Instability in Europe After the Cold War," International Security 15:1 (Summer 1996) 5-56; Quincy Wright, $A$ Study of War $2^{\text {nd }}$ ed. (Chicago: Chicago University Press, 1965); Geoffrey Blainey, The Causes of War $3^{\text {rd }}$ ed. (New York: Free Press, 1988); Jack S. Levy, "The Causes of War: A Review of Theories and Evidence," Behavior, Society, and Nuclear War: Vol. I, eds. Philip E. Tetlock, et at., (New York: Oxford University Press, 1989) 209-333; Michael E. Brown, Sean Lynn-Jones, and Steven E. Miller, eds., The Perils of Anarchy: Contemporary Realism and International Security (Cambridge: Massachusetts Institute of Technology Press, 1995); United States National Strategy for Combating Terrorism, September 2006, 30 May 2007

$<$ www. whitehouse.gov/nsc/nsct/2006/>; The National Security Strategy of the United States of America, March 2006, 30 May $2007<$ www.whitehouse.gov/nsc/nss/2006/>; Robert J. Art and Kenneth N. Waltz, eds., The Use of Force: Military Power \& International Politics $6^{\text {th }}$ ed. (Rowman: Lanham, 2004); John J. Mearsheimer, "Why We Will Soon Miss the Cold War," The Atlantic 266.2 (Nov. 1990) 35-50; Richard K. Betts, ed., Conflict After the Cold War: Arguments on Causes of War and Peace $2^{\text {nd }}$ ed. (Pearson: New York, 2005); Kenneth N. Waltz, Theory of International Politics (New York: McGraw Hill, 1979); Hans J. Morgenthau, Politics Among Nations: The Struggle For Power and Peace, $6^{\text {th }}$ ed., ed. Kenneth W. Thompson (New York: McGraw-Hill, 1993); George F. Kennan, "Diplomacy in the Modern World," Classics of International Relations, ed. John A. Vazquez (Englewood Cliffs: Prentice Hall, 1986).

${ }^{107}$ See John G. Ruggie, Constructing the World Polity: Essays on International Institutionalization (New York: Routledge, 1998); Alexander Wendt, "Constructing International Politics," International Security 20.1 (Summer, 1995) 71-81; Alexander Wendt, "Anarchy is What States Make of 1t: The Social Construction of Power Politics, International Organization 46.2 (Spring 1992) 391-425; David Dessler, "What is at Stake in the Agent-Structure Debate?" International Organization 43.3 (1989) 441-474; Michael Nicholson, "The Continued Significance of Positivism?" International Theory: Positivism \& Beyond, eds. Steve Smith, Ken Booth, Martha Zalewski (Cambridge: Cambridge University Press, 1996) 128-145; Richard Ashley, "The Poverty of Neo-realism." Neo-realism and Its Critics, ed. Robert O. Keohane (New York: Columbia University Press, 1986) 255-300.

${ }^{108}$ Nicholson 20.
} 
"assumes that ready-made ideas exist before words ... [and] lets us assume that the linking of a name and a thing is a very simple operation." ${ }^{\prime 109}$ This is how 9/11 has been construed and interpreted, and why it forms an irrefutable basis for pursuing the US $A S A$. According to V.W. Quine, it is quite misleading to speak of the objective content of a statement; any statement can be held true based on shifting standards of correctness, truth. No statement is "immune" to revision." "If a thought were correct a priori, it would be a thought whose possibility ensured its truth. A priori knowledge that thought was true would be possible only if its truth were recognizable from the thought itself.",11 The simulation of a priori truth generates loci of enunciation-that is, points where interactive, complex knowledge systems intersect - that create the bases for legitimate and authoritative categories to define and implement security. ${ }^{112}$

Signifiers such as US-Global-Justice, US-Global-Freedom, US-Global-Security, US-Global-Democracy, and US-Global-Development are arbitrary prescriptions as opposed to fixed, stable, and definite states of affairs based on universal norms. "The bond between the signifier and the signified is arbitrary."113 Objectivity is, as Pierre Bourdieu notes, a product of a field of perceptual and conceptual effects "which depends on the presuppositions accepted in the field, particularly as regards the legitimate way of

\footnotetext{
${ }^{109}$ Ferdinand de Saussure, "Course in General Linguistics," trans. Wade Baskin, The Norton Anthology of Theory and Criticism, eds. Vincent B. Leitch, William E. Cain, Laurie A. Fink, Barbara E. Johnson, John McGowan, and Jeffery J. Williams (New York: W.W. Norton, 2001) 963.

${ }^{110}$ See V. W. Quine, "Two Dogmas of Empiricism," Challenges to Empiricism, ed. Harold Link-Morick (Belmont: Wadsworth Publishing, 1972).

111 Wittgenstein, Tractatus 13.

${ }^{112}$ See Michael J. Shapiro, Methods and Nations: Cultural Governance and the Indigenous Subject (New York: Routledge, 2004).

${ }^{113}$ Saussure 964 .
} 
settling conflicts." 114 Prescriptive language has the "extraordinary effect of making us change worlds or of changing the world. To change the world in which we live and make us change language ... as well. An effect not to be found anywhere else." "115 The US $A S A$ collapses distinctions between signs and signifiers, establishing a dissertation of knowledge and power that, in turn, is used to manufacture first principles that are bestowed and/or discovered, such as the utility of US power providing the basis for the global system.

The US $A S A$ is brazenly antithetical to the founding principles of the modern international system. Hans Morgenthau observes that, "political realism, [the basis of modern international relations,] refuses to identify the moral aspirations of a particular nation with the moral laws that govern the universe."116 The US ASA, however, seeks to universalize one state's aspirations, casting an illimitable "net" as far as what qualifies as a "threat." It leaves open the possibility of securitizing any activities and actors as possible fodder for global security measures, generating a totalizing epistemology of how and why to securitize. The US categorically asserts that, "We are a Nation blessed with unprecedented liberty, opportunity, and openness-foundations of the American way of life. Our principal terrorist enemies-al-Qaida, its affiliates, and those inspired by them-seek to destroy this way of life."

\footnotetext{
${ }^{114}$ Pierre Bourdieu, Science of Science \& Reflexitivity, trans. Richard Nice (Chicago: University of Chicago Press, 2004) 71 .

${ }^{115}$ Lyotard, Gaming 51.

${ }^{116}$ Hans J. Morgenthau. Politics Among Nations: The Struggle for Power \& Peace $4^{\text {th }}$ ed. (New York: Alfred Knopf, 1966) 30.

${ }^{117}$ The White House, National Strategy for Homeland Security October 2007, 19 Aug. $2008<$ http://www.whitehouse. gov/in focus/homeland/nshs/2007/index.html>.
} 
Under the US $A S A$, the states system is reduced to being an extension of the US. In particular, the US reserves the categorical and unilateral right to decree final pronouncement on the legitimacy of an international actor and its security policies, and to act as an objective, referential authority of how world affairs are to be defined and implemented. International actors are, therefore, accorded degrees of legitimacy and functionality based upon a set of subjective criteria that are ubiquitous yet singular, domestic yet international, and state-centric yet selective as to what qualifies as a legitimate international actor. The US is able to justifiably pursue such courses of action based on the fact that anyone can be a terrorist, anything can be used to perpetuate terror, and (in particular) those who perpetuate terror use their own deaths to further their cause. "Terrorists, while they have at their disposal weapons that are the system's own, possess a further lethal weapon: their own deaths." 118 During the $43^{\text {rd }}$ Munich Security Conference, Russian President Vladimir Putin's critiques of US security policy touched upon the modus operandi of the US ASA:

What is a uni-polar world? No matier how we beautify this term, it means one single center of power, one single center of force and one single master ... The US has overstepped its borders in all spheres - economic, political and humanitarian, and has imposed itself on other states. ${ }^{119}$ [US security policy] is a formula that ... has led to disaster: Local and regional wars did not get fewer ... We see no kind of restraint-a hyperinflated use of force. ${ }^{120}$

\footnotetext{
${ }^{118}$ Baudrillard, Spirit 20.

${ }^{119}$ Vladimir Putin, speech, $43^{\text {rd }}$ Munich Security Conference, 10 Feb. 2007, BBC News Online, 1 June 2007

$<$ http://new s.bbc.co.uk/2/hi/europe/6349287.stm>.

${ }^{120}$ Vladimir Putin, speech, $43^{\text {rd }}$ Munich Security Conference, 10 Feb. 2007, BBC News Online, 1 June 2007

$<$ http://new s.bbc.co.uk/2/hi/europe/6349287.stm>.
} 
Regarding the role of material power in international relations, Hans Morgenthau observes that, "international politics, like all politics, is a struggle for power. Whatever the ultimate aims of international politics, power is always the immediate aim," and involves control "over the minds and actions of" international actors. ${ }^{121}$ Power is, therefore, complex, multidimensional, and permeates all aspects of international relations. Utilizing an $A S A$, the US seeks control over information and knowledge in "constant interplay with other media" to enhance US power. ${ }^{122}$ Hence, $9 / 11$ functions as the objective and shared reference point for all international actors for the establishment of an absolutist security agenda. After all, if terror is not destroyed where it grows, that is, anywhere and everywhere, then the entire global community is in ominous mortal danger. The knowledge that emanates from knowledge systems therefore plays a fundamental role in the message-articulation and manifestation of power, and the event of 9/11 forms the moral, conceptual, and security superstructure for pursuing a full-fledged $A S A$. As Kenneth Boulding notes, the "meaning of a message is the change which it produces in the image. Concern with effect rather than meaning is a basic [dynamic] of power-in-practice, for effect involves the total situation, and not a single level of information." 123 The effect of $9 / 11$ is to provide an objective, in-frangible basis for the unilateral exercise of US power on the world stage.

\footnotetext{
${ }^{121}$ Hans J. Morgenthau, Politics Among Nations: The Struggle for Power \& Peace 6 ${ }^{\text {th }}$ ed. (revised) ed. Kenneth W. Thompson (New York: Alfred A. Knopf, 1985).

122 McLuhan 26.

${ }^{123}$ Kenneth E. Boulding, The Image (Ann Arbor: University of Michigan Press, 1961), cited in Understanding Media: The Extensions of Man, by Marshall McLuhan, intro. Lewis H. Lapham (Cambridge: Massachusetts Institute of Technology Press, 2002) 26.
} 
Perceptions of power run the gamut of possibility. Graham Evans and Jeffrey Newnham find power to be a "portmanteau concept," virtually impossible to define with any degree of precision, and Robert Gilpin describes "the concept of power as one of the most troublesome in the field of international politics."124 For Robert Keohane and Joseph Nye, power is an "elusive concept for statesmen and analysts of international politics." 125 Susan Strange contends that the systemic structure of power consists of specific micro-power structures of security, knowledge, production, and finance, each component being of equal weight and interacting amongst each other. ${ }^{126}$ Michel Foucault views power as relational: "There are power relations. They are multiple; they have different forms, they can be in play in family relations, or within an institution, or an administration - or between a dominating and a dominated class, power relations having specific forms of rationality, forms which are common to them. It is a field of analysis and not at all a reference to any unique instance."127 Economy, cooperation, regimes, the military, ideas, discourse, epistemology, material resources, states, geopolitics, propaganda, culture, politics - indeed, there is a superabundance of perspectives and definitions of power that abound in the literature. The US $A S A$ augments US power to define global security by having a preponderance of tangible (military) and intangible (social, symbolic, cultural) power that "characterizes the existence, circulation, and

\footnotetext{
${ }^{124}$ Graham Evans and Jeffrey Newnham, The Dictionary of World Politics (London: Harvester Wheatsheaf, 1992) 446; Robert Gilpin, War \& Change in the International System (Cambridge: Cambridge University Press, 1991) 13.

${ }^{125}$ Robert O. Keohane and Joseph S. Nye, Power \& Interdependence: World Politics in Transition $2^{\text {nd }}$ ed. (New York: Longman, 1989) 11.

${ }^{126}$ See Susan Strange, "The Persistent Myth of Lost Hegemony," International Organization 41.4 (Fall 1987) 551-574, and "The Persistent Myth of Lost Hegemony: Reply to Milner and Snyder," International Organization 42.4 (Fall 1988) $751-52$.

${ }^{127}$ Foucault, Politics 38
} 
operation of [security] discourses within a society." 128 With the moral and ethical might to ground US security policy and action, the US $A S A$ enables the US to exercise social and material power in tandem in order to produce truth via knowledge, since "the subject is constituted through practices of subjection, or, in a more autonomous way, through practices of liberation, of liberty, ... on the basis, of course, of a number of rules, styles, inventions to be found in [a social, political, economic, moral, and] cultural environment." 129

Although there is a voluminous literature on power in international relations, four distinct yet inter-relational spheres of power can be clearly identified in the US ASA: Political, Cultural/Symbolic, Economic, and Military/Coercive power. Political power involves the capacity of an actor to authoritatively define, organize, and manage/implement individual and group life within a larger configuration of order. Political power forms control and command rubrics, for example, procedural democracy, that establish legitimate knowledge systems. Cultural/Symbolic power involves and refers to nonmaterial means, for example, ideas, language, and master symbols of legitimation (see below), to disseminate ordering-principles. Economic power is rooted in the ownership/control of private property in the form of tangible resources such as fossil fuels and land. "This power sphere enables the power-bearer to possess the ability to transform human, material, and financial resources into goods and services, for sale or exchange in a market, in order to generate a means of subsistence" and wield power

\footnotetext{
${ }^{128}$ Michel Foucault, "What is an Author?" The Norton Anthology of Theory and Criticism, eds., Vincent B. Leitch, William E. Cain, Laurie A. Fink, Barbara E. Johnson, John McGowan, and Jeffery J. Williams (New York: W.W. Norton, 2001) 1628.

${ }^{129}$ Foucault, Politics 50-51.
} 
through profit. ${ }^{130}$ Lastly, military power involves the material capacity of an actor to exercise police powers as well as wage or threaten offensive and defensive physical warfare against foes. In an $A S A$ rubric, power is a combination of material (force) and non-material (ideas) components, with ideas such as morality being as paramount as crude military might. As E.H. Carr observes, "theories of social morality are always the product of a dominant group which identifies itself with the community as a whole, and which possesses facilities designed to subordinate groups or individuals [to impose] its view of life on the community. Theories of international morality are, for the same reason and in virtue of the same process, the product of dominant nations." ${ }^{\prime 131}$ In the case of the US international theory of morality embodied in the US ASA, the National Strategy for Homeland Security 2007 issues sweeping pronouncements that advocate a unitary executive state via homogenization of security interests via immanent terror:

To best protect the American people, homeland security must be a responsibility shared across our entire Nation. As we further develop a national culture of preparedness, our local, Tribal, State, and Federal governments, faith-based and community organizations, and businesses must be partners in securing the Homeland ... This Strategy also calls on each of you ... As we secure the Homeland, however, we cannot simply rely on defensive approaches and well-planned response and recovery measures. We recognize that our efforts also must involve offense at home and abroad. We will disrupt the enemy's plans and diminish the impact of future disasters through measures that enhance the resilience of our economy and critical infrastructure before an incident occurs. ${ }^{132}$

\footnotetext{
${ }^{130}$ Duong 37.

${ }^{131}$ Carr, "Realism" 71.

${ }^{132}$ The White House, National Strategy for Homeland Security October 2007, 19 Aug. $2008<$ http://www.whitehouse. gov/infocu s/homeland/nshs/2007/index.html>.
} 
This sweeping pronouncement effectively blurs the lines between traditionally distinct categories, creating a homogenized, centralized, law-enforcement-based and militarized panoptic surveillance apparatus premised on patriotism, loyalty, fidelity, and duty to the elimination of terror in any and all of its manifestations.

Morality \& Symbol

Morality assumes a pivotal and singular role, both in interpreting $9 / 11$ and in framing the post-9/11 security context. The moral, however, can be adjusted to proffer the intrinsic superiority/correctness of any particular moral posture; indeed, morality encompasses a relative, subjective state of affairs. A moral prerogative enables one to declare that a particular political, social, and economic modality must necessarily be the case. Yet morality as a form of knowledge must be strictly scrutinized, since "knowledge leads to control, and control is possible because institutions, and thus men ... are infinitely manipulable." 133 A "correct" or superior morality is effectuated via knowledge. "The insidious thing about the [moral] point of view is that it leads us to say: 'Of course it [has to be] like that.' Whereas we ought to think: it may [be like] that-and also in many other ways." 134 An examination of the war on terror and rogue states reveals that the privileging of a moral perception occurs in the framing and definition of security, and that the privileging of one reality and actor occurs at the expense of another. ${ }^{135}$

\footnotetext{
${ }^{133}$ Waltz, Man 75.

${ }^{134}$ Ludwig Wittgenstein, Culture \& Value, trans. Peter Winch (Chicago: University of Chicago Press, 1980$) 37$.

135 See Michel Foucault, Society Must Be Defended: Lectures at the College de France, 1975-1976, trans David Macy, intro. Arnold 1. Davidson, ed. and forward François Ewald, Alessandro Fontana, and Mauro Bertani (New York: Picador, 2003).
} 
In a unipolar world, "terror" (as extrapolated from the event of $9 / 11$ by the US) and the notion of "Homeland" have become the operative Master Symbols of Legitimation (hereinafter, MSL) that inform the postulation of global security. ${ }^{136}$ MSL, in general, are part of a nomenclature that have the effect of generating and reifying selfcontained knowledge systems of a particular modality of order through the use and examination of MSL. Particular constellations of order deploy a specific epistemologyone that embodies distinct ordering assumptions and principles-that utilize MSL to manufacture and deploy categories and information. The power of MSLs reside in the ability of actors to authoritatively designate and fix signification; MSL justify, explain, and reify subject matter without having to rely upon external sources of justification. In the case of the US $A S A$, terror and Homeland have come to absorb and/or displace traditional MSL such sovereignty and the states system. The US defines Homeland Security as "a concerted national effort to prevent terrorist attacks within the US, reduce America's vulnerability to terrorism, and minimize the damage and recover from attacks that do occur."137 This definition explicitly encompasses multifarious levels of thought and action: all levels of government, the private sector (including religious and other non-profit single-issue groups), foreign and domestic policy in a host of different sectors, various communities, and most especially the individual. The US will stop at nothing to securitize anything and everything, placing the polity and all other states on a militarized war-response track.

\footnotetext{
${ }^{136}$ C. Wright Mills, The Sociological Imagination, afterword Todd S. Gitlin (New York: Oxford University Press, 2000) 1-20.

${ }^{137}$ The White House, National Strategy for Homeland Security October 2007, 19 Aug. $2008<\mathrm{http}$ ://www.whitehouse. gov/infoc us/homeland/nshs/2007/index.html>.
} 
In order to realize this vision, the US will use all instruments of national power and influence-diplomatic, information, military, economic, financial, intelligence, and law enforcement-to achieve our goals to prevent and disrupt terrorist attacks; protect the American people, critical infrastructure, and key resources; and respond to and recover from incidents that do occur. We also will continue to create, strengthen, and transform the principles, systems, structures, and institutions we need to secure our Nation over the long term. ${ }^{138}$

Within an $A S A$ rubric, the categories "enemy combatant," "terrorist," "rogue state," "freedom" and "peace," amongst others, fall under the MSL of terror. The "new" enemy of the US, terror, legitimates unilateral security policies.

Our enemy is a radical network of terrorists, and every government that supports them. Our war on terror begins with al Qaeda, but it does not end there. It will not end until every terrorist group of global reach has been found, stopped and defeated ... [Terrorists] hate ... a democratically elected government. Their leaders are self-appointed. They hate our freedoms - our freedom of religion, our freedom of speech, our freedom to vote and assemble and disagree with each other. ${ }^{139}$

Yet, who is a terrorist and what constitutes (objective) terror fluctuates; as uncomfortable as the fact may be, terrorist "hate" and "evil" are un-falsifiable states of affairs that lie in the eye of the beholder. US support of Contra "freedom fighters" in Nicaragua during the 1980s under the Reagan administration, or the more recent case of the US preventing suspected terrorist Luis Posada Carriles to be tried by Cuba and Venezuela for an

\footnotetext{
${ }^{138}$ The White House, National Strategy for Homeland Security October 2007, 19 Aug. $2008<$ http://www.whitehouse. gov/infoc us/homeland/nshs/2007/index.html>.

${ }^{139}$ George W. Bush, speech, US Capitol, Washington, D.C., 20 Sept. 2001, The George W. Bush Foreign Policy Reader: Presidential Speeches with Commentary, ed. John W. Dietrich (New York: M.E. Sharpe, 2005) 52.
} 
assassination attempt against Fidel Castro in 2002 and the terrorist bombing of a Cuban airliner in 1976, highlight the bias and relativity of definitions of terror. ${ }^{140} 9 / 11$ and the security framework crafted on its occurrence construes terror as noun (thing), verb (action), and adjective (descriptive category). It is perpetuated and perpetuates. In the US $A S A$, terror is accorded agency, meaning, and significance independent of specific actors. "Al "All testing, all confirmation and disconfirmation of [the US definition] takes place already within an $[A S A]$ system." 142 The moral meta-language employed in the $A S A$ is a basis for legitimating the unilateral exercise of US power. In all configurations of order, however, there is "no meta-language ... that [can] ground political and ethical decisions that [can] be taken as the basis of its statements. There is no moral metalanguage; there are only genres of language, genres of discourse."143 What qualifies as good, right, proper, and/or a just means of resistance to "authoritative" power has no objective definition. Terrorism is a means as opposed to an end in itself, and can be viewed as an asymmetric "strategy of coercion" in the service of some "higher" substantive aim, as opposed to a pure machination of "evil."144 The US $A S A$, premised on terror and defense of the US Homeland, seeks to globally disseminate a security framework that is binary yet open-ended, illimitable and absolute.

\footnotetext{
140 “Alleged Cubana Bomber Ordered Freed," BBC Caribbean News Online 13 Sept. 2006, 4 June $2007<$ http://www. bbc.co.uk/caribbean/news/story/2006/09/060913 posada.shtml>.

${ }^{141}$ Martha Crenshaw, Terrorism \& International Cooperation (New York: Institute for East-West Studies, 1989 ) 5.

${ }^{142}$ Ludwig Wittgenstein, On Certainty, trans. Dennis Paul and G.E.M. Anscombe, eds. G.E.M. Anscombe and G.H. von Wright, (New York: Harper, 1969) 16.

${ }^{143}$ Lyotard, Gaming 28.

${ }^{144}$ Richard K. Betts, "The Delusion of Impartial Intervention," Conflict After the Cold War: Arguments on Causes of War \& Peace $2^{\text {nd }}$ ed., ed. Richard K. Betts (New York: Pearson Longman, 2005) 521.
} 
The US $A S A$ is therefore effectuated via a discrete set of ideas concerning the form and substance of international order. ${ }^{145}$ The values embodied in a US-based conceptualization of US-Domestic-Security-Equals-Global-Security have become the referents for global security vis-à-vis international affairs. ${ }^{146}$ Because of its claims to universality, the US $A S A$ dispenses with the notion that security "is a social construct with different meanings in different societies," and adheres to a framework that propagates the objective status and moral superiority of a US-based, organized, and managed world order. ${ }^{147}$ Overall, this conception negatively effects global security in practice. ${ }^{148}$ Viable and violent centers of resistance in the form of militarization and proliferation have developed in response to US security policy. Terrorists and statesponsors of terror are frequently accused of seeking to forcibly impose a particular modality of being on an unwilling recipient through violent means; this is one of the premises of US security that has devolved from $9 / 11 .^{149}$ Ironically, this modus operandi and end-goal are exactly what the US seeks to effectuate via an $A S A$. Indeed, terrorist violence and ideology can be traced to the absolutist security policies of the US. By

\footnotetext{
${ }^{145}$ See Charles and Clifford Kupchan "The Promise of Collective Security," International Security 20:1 (Summer $1995)$ 52-61; John Owen, "How Liberalism Produces Democratic Peace," International Security 19:2 (Fall 1994); Hugo Grotius, "Prolegomena to the Law of War \& Peace," Classics of International Relations, ed. John A. Vasquez (Englewood Cliffs: Prentice Hall, 1986) 327-329.
}

\footnotetext{
${ }^{146}$ See Jose E. Alvarez. "Hegemonic International Law Revisited," 97 A. J. I. L. 873, The American Society of International Law, American Journal of International Law (2003), 20 Jan. $2007<\mathrm{http} / /$ web.lexisnexis.com.ezproxy.fiu.edu>

${ }^{147}$ Myron Weiner, "Security, Stability, and International Migration," International Security 7.3 (Winter 1992-1993) 91126.

${ }^{148}$ See Robert Jervis, "The Security Dilemma," Conflict After the Cold War: Arguments on the Causes of War and Peace $2^{\text {nd }}$ ed., ed. Richard K. Betts (New York: Pearson-Longman, 2005), regarding the "security dilemma" that occurs when states perceive/mis-perceive state security intentions.

${ }^{149}$ For a recent high profile recrimination against the perpetuators of terror, see US Senator Hillary Clinton's comments on terrorism in, "Transcript: The Democrats' Second 2008 Presidential Debate," New York Time Online, 3 June 2007, 4 June $2007<\mathrm{http}: / /$ www.nytimes.com/2007/06/03/us/politics/03demsdebate_transcript.html>.
} 
defining the "new" threat to US-global security as consisting of malevolent, terroristic violence sponsored by rogue states, for instance, the US effectively neutralizes the legitimacy of any form of violent resistance to unipolar control. For instance, if "terrorism" is indeed the only or most viable means by which weaker states and non-state actors can (violently) resist US unipolarity-because the rules of global security formation classifies any form of violent resistance as criminal, terroristic - then there can be no legitimate resistance to US power. The use of force may be considered the only option available to those who resist a singular unipolar power in an anarchic world. Yet, force, violence, and resistance carried out by any other actor but the US and its allies are considered improper and summarily criminalized.

Beneath a veneer of peace, the US $A S A$ is premised and thrives on force and panoptic surveillance. "Force" is applied in all sectors and levels of international affairs, for example, in the realms of global trade, allocation of financial resources, control of states through governmental and non-governmental organizations, military aid, development aid, international embargos, and diplomatic and economic isolation, amongst several other means. Only the US has the authority to wage war, or rather wage peace through war; war not only becomes the continuation of politics, but politics becomes the extension of war by other means. ${ }^{150}$ The US $A S A$ assumes that "to introduce into the philosophy of War itself a principle of moderation would be an absurdity."151 Hence, the "new" rules of formation pertaining to global security involve:

\footnotetext{
${ }^{150}$ Carl von Clausewitz, On War, ed., and intro. Anatol Rapoport (New York: Penguin Books, 1982) 119; Foucault. Society 15 .

${ }^{151}$ Clausewitz 102; Foucault, Society 5.
} 
a movement from a policy of contention, dissuasion, and limited use of military force to a policy of decisive unilateral prevention, where reprisals are based on massive military force and an increase of covert actions whose emphasis is on action, not restraint; the use and/or threat of force is the focus of foreign policy, and the use of moral values to legitimize US decisions in international organizations, such as the UN, when interpreting international treaties, such as the NPT, and conducting relations with allies and designated enemies of global peace and security; the definition of terrorism is understood not in terms of motives and causes but in the nature of the act itself, which expands the criteria beyond what was traditionally accepted to include physical, psychological, economic damage and destruction, and fear among civilians. ${ }^{152}$

In the realm of surveillance, the US has proclaimed that:

The unimpeded exchange of information should be the rule, not the exception, in our efforts to combat the terrorist threat ... Improving information sharing in the post-September 11 world requires an environment that supports the sharing of information across all levels of government, disciplines, and security domains. As with our achievements to date, an improved information-sharing environment will not be constructed overnight, [and] will be constructed upon a foundation of trusted partnerships among all levels of government, the private sector, and our foreign allies-partnerships based on a shared commitment to detect, prevent, disrupt, preempt, and mitigate the effects of terrorism.

Intemperate aggression, illimitable surveillance, and the use of military force with virtually no apparent limits contribute to an unstable and enervated international framework for ensuring the security of the US and all states. James Madison's

\footnotetext{
${ }^{152}$ Soraya Castro Marino, "The Cuba-US Conflict: Notes for Reflection in the Context of the War Against Terrorism," Foreign Policy Toward Cuba: Isolation or Engagement? eds. Michele Zebich-Knos and Heather N. Nicol (Lanham: Lexington Books, 2005) 192-193.

${ }^{153}$ The White House, National Strategy for Information Sharing October 2007, 19 Aug. $2008<$ http://www.whitehous e.gov/nse/ infosharing/index.html>.
} 
observations in 1795 concerning war and its effects retain validity in a post-9/11 security context: "Of all the enemies of true liberty, war is, perhaps, the most to be dreaded, because it comprises and develops the germ of every other. War is the parent of armies; from these proceed debts and taxes; and armies, and debts, and taxes are the known instruments for bringing the many under the domination of the few ... No nation can preserve its freedom in the midst of continual warfare." 154 No borders, no clear rules, no identifiable enemy - all describe current US security policy. The attempt to inaugurate an US-National-Security-Equals-Global-Security framework renders threat and enemies ubiquitous, protean, fomenting uncertainty by imposing homogeneity on a world system that is immanently heterogeneous in character and content. According to S. C. Marino,

the new national-security doctrine establishes the right of the US, in an aggressive and expansionist manner and without proof of the threat or type of threats, to initiate defensive intervention ... the US ... reserves for itself the right to use a broad range of public resources and instruments to undertake military intervention ... This allows little space for positive dialogue, including on subjects of vital interest between [all states]. ${ }^{155}$

The US has established some of the following institutions, policies, agencies, and other apparatuses on the basis of the 9/11 war-response: The US has

a Department of Homeland Security ... created a Director of National Intelligence; shifted the FBI's focus from investigating terrorist attacks to preventing them; created a new National Counterterrorism Center; created Treasury's Office of Terrorism

\footnotetext{
154 James Madison, "Political Observations, April 20, 1795," 11 June $2008<$ http://www.reclaimdemocracy.org/quotes /madison_perpetual_war.html>.

${ }^{155}$ Marino, "Cuba-US" 205.
} 
and Financial Intelligence; enacted the Patriot Act and tore down the 'wall' that once prevented law enforcement and intelligence officers from sharing vital information; worked ... to pass the Foreign Intelligence Surveillance Amendments Act, which allows our intelligence professionals to quickly and effectively monitor terrorist communications [without undue obstacles]. ${ }^{156}$

Such apparatuses and the operative principles that underlie the US $A S A$ undermine global security by undermining the states system. This is the case because the tools that the US has given itself to perpetuate absolute security are myopically focused on the absolute weal of one state, to the detriment of all others when it comes to state sovereignty and respect for diversity amongst states. Unfettered panoptic surveillance in the form of information "fusion centers," extraordinary rendition, militarization of law enforcement, and the legal, economic, and military means to forcibly impose US mandates on other states via the war on terror all attenuate sovereignty, diversity of state interests, and states' right to political self-determination. ${ }^{157}$ The US Homeland, under an $A S A$, becomes the singular reference point for adjudging the efficacy, correctness of any security measure, summarily dismissing out of hand any other conceptualization, rationalization, interest, etc., that is at odds with US security.

Security \& Rules of Formation

Establishing an enemy involves rules of formation. The US ASA does not acknowledge that the "truth of certain ... propositions belongs to our frame of

\footnotetext{
${ }^{156}$ The White House, Fact Sheet: Protecting America From Terrorism, 20 Aug. 2008, 20 Aug. $2008<$ http://www.whit ehouse.gov/infocus/nationalsecurity/>.

${ }^{157}$ See National Strategy for Information Sharing October 2007, The White House, 19 Aug. $2008<$ http://www.white house.gov/ nsc/infosharing/index.html $>$.
} 
reference. 158 9/11 is touted by the US as the basis of a universal moral, ethical, and total-war response disseminated throughout the globe; all states must recognize, empathize, and interpret $9 / 11$ as the US posits. To refuse the US interpretation is to be marginalized, possibly provoking the ire of the world's hyper-power. Terror and rogue states, after $9 / 11$, are presented as universal threats as opposed to state-specific, contextbased threats. The US $A S A$ disseminates particular modalities of knowledge and truth, and examination of the rules pertaining to security and how they are made, communicated, administered, interpreted, enforced, legitimized, and disseminated sheds light on how the US manufactures and disseminates knowledge. ${ }^{159}$ The articulation and implementation of rules of formation have the consequence of being "directed towards the preservation of order, not [only] by directly upholding or implementing the rules, but by shaping, molding or managing the social environment in which the rules operate." $" 160$ The $A S A$ posited by the US presents the US as the "organic bond uniting hierarchized individuals" on a global level. ${ }^{161}$ In the case of securing the blessings of liberty for all states, a positive effect of the US $A S A$ - even those that do not solicit US intervention or desire the US governance template-the US categorically asserts that,

in Afghanistan, we removed a dangerous regime that harbored the terrorists who plotted the attacks of $9 / 11$. Because we acted, the Afghan people have been liberated, and a nation that was once a training ground for terrorists has become an ally in the war on terror. We built a strong coalition of nations, including

\footnotetext{
${ }^{158}$ Wittgenstein, Certainty 12.

${ }^{159}$ Bull, Anarchical 54-56.

${ }^{160}$ Bull, Anarchical 57.

${ }^{161}$ Gilles Deleuze and Felix Guattari, What is Philosophy? eds. and trans. Hugh Tomlinson, Janis Tomlinson, and Graham Burchell (New York: Columbia University Press, 1994) xiv.
} 
every member of the NATO Alliance, to help the Afghan people defend their young democracy. We will ensure Afghanistan never again becomes a safe haven for terrorists seeking to launch attacks on America or our allies. In Iraq, an international coalition removed a brutal dictator who murdered his own people, paid the families of suicide bombers, invaded his neighbors, and repeatedly defied UN resolutions. In 2006, the situation in Iraq was deteriorating, so the President ordered a surge of forces into Iraq. Since the surge began violence in Iraq has dropped, civilian deaths and sectarian killings are down, and political and economic progress is taking place. Iraq is a rising democracy. ${ }^{162}$

To reject or challenge US power is "rogue" in nature, meriting considerable, aggressive retaliation, whether in the form of rhetoric and/or economic sanctions, preemptive/preventive warfare, political and diplomatic isolation, severe economic sanctions, military invasion/occupation, denial of global development aid via the IMF or World Bank, massive military aid to perceived enemies of rogue states (such as military aid to South Korea), and selective overt/covert attempts to topple and replace various (rogue) regimes. ${ }^{163}$

The objective veracity of the US $A S A$, however, is tenuous at best. As Jean François Lyotard observes, "no maker of statements, no utterer, is ever autonomous. On the contrary an utterer is always someone who is first of all an addressee ... he is someone who, before he is the utterer of a prescription, has been the recipient of a prescription, and that he is merely a relay; he has also been the object of a prescription." 164 When analyzing rules of formation, Ludwig Wittgenstein is correct to

\footnotetext{
${ }^{162}$ The White House, Fact Sheet: Protecting America From Terrorism, 20 Aug. 2008, 20 Aug. $2008<$ http://www. whitehouse.gov/infocus/nationalsecurity/>.

${ }^{163}$ For examples, see Mark Zepezauer, The CIA's Greatest Hits (Monroe: Odonian/Common Courage Press, 1994).

${ }^{164}$ Lyotard, Gaming 31.
} 
note that, "Language disguises thought. So much so, that from the outward form of the clothing it is impossible to infer the form of thought beneath it, because the outward form of the clothing is not designed to reveal the form of the body, but for entirely different purposes." 165 The actual content of the US ASA is hidden behind a veneer of language that is familiar, accepted, and grounds international relations. After all, are not peace, freedom, stability, and development "good" things? In the case of globalization, the US is adamant that it has brought prosperity to the world community.

Much of the world's prosperity and improved living standards in recent years derive from the expansion of global trade, investment, information, and technology. The United States has been a leader in promoting these developments, and we believe they have improved significantly the quality of life of the American people and people the world over. Other nations have embraced these opportunities and have likewise benefited. Globalization has also helped the advance of democracy by extending the marketplace of ideas and the ideals of liberty. These new flows of trade, investment, information, and technology are transforming national security. Globalization has exposed us to new challenges and changed the way old challenges touch our interests and values, while also greatly enhancing our capacity to respond. ${ }^{166}$

Yet, the traditional "facts," the basic realities of sovereignty, self-determination, and the states system, are colored and have meaning imputed to them that is not in accord with the actual initial and basic meaning/significance of these "facts." To produce freedom by overwhelming military force, embargos, and other coercive measures, as in the cases of Iraq and Afghanistan vis-à-vis invasion and occupation and Cuba via a

\footnotetext{
${ }^{165}$ Wittgenstein, Tractatus 22.

${ }^{166}$ The White House. The National Security Strategy of the United States of America, March 2006, 30 May 2007 $<$ http://www.whitehouse.gov/nsc/nss/2006/sectionX.html>.
} 
permanent US embargo, is a self-contradictory premise (one must be forced to be free?). To discard or marginalize the civil rights/liberties of a "free" populace in the name of security is hardly in line with the tenets of genuine freedom. Language therefore provides protective and obfuscating screens, fixing attention on the term (freedom) while simultaneously reconfiguring it. Equating justice, peace, and freedom with US modalities of global governance is the means by which this exchange occurs. For example, in globally institutionalizing the war on terror, premised on the organic propriety of US socioeconomic and political precepts, the US has established the Partnership for Progress and a Common Future to support political, economic, and social reform in the Broader Middle East and North Africa (BMENA), launched by the G-8 in 2004. This region of the world has its own history, culture, priorities, religious postures, and the like, and has been historically anti-colonialist and anti-Western because of its tumultuous and exploitative relations it has had with the West, the US in particular. Indeed, the Iranian (1979) and Libyan (1969) revolutions were direct results of US and Western interference that sought to mold these countries in a Western/ US image for the sake of material and political benefits. Theocracy and self-determination, among other variables, simply do not comport to the US template. Yet, because the US desires security from terror in the present age, the region is now viewed as having no choice but to adapt the sociopolitical and economic premises of US global governance.

The US and the G-8, together with regional partners in the Middle East, developed the Forum for the Future to advance freedom, prosperity, and opportunity. Bringing together leaders in government and civil society, the Forum is an opportunity to anchor reform in the region. Through the BMENA initiative and the Forum, foreign, finance, and educational ministerial meetings 
are taking place. In addition, the Forum brings together civil society and business in dialogues to energize and focus reform and connect these vital actors with government participants. ${ }^{167}$

It is important to note that, "any discourse meant to account for prescriptions, transforms them into conclusions of reasoning, into propositions derived from other propositions, in which the latter are metaphysical propositions on being and history, or on ... society. In such a derivation ... what is derived or deduced is not the prescriptive itself but the citation of the prescriptive, that is, the image, the representation ... of the prescriptive."168 The imprimatur of the unipolar state as legitimating a system of security relies upon the power to circumscribe reality via rulemaking. Rulemaking is part of the process whereby signification occurs within a system of object-signifieds. Signifieds rely upon imagery to retain signification. In any security system, an authority "depends upon a fundamental or constitutional principle, stated or implied, which singles out certain [actors] as the sole bodies competent to discharge ... political functions."169 In the "new" security context, the US is the singular actor that is competent to discharge security functions. Security is conditioned on the knowledge and ideas that a subject/actor draws upon to form ideas of what constitutes security. Knowledge is the basis for prescription. Perceptions and prescriptions of security will therefore vary according to the world-view of a subject. If that worldview is based on the US $A S A$, then the US assumes a "natural" position at the apex of power in the states system, because the $A S A$ template articulates

\footnotetext{
${ }^{167}$ The White House, 9/11 Five Years Later: Successes and Challenges September 2006, 21 Aug. $2008<\mathrm{http}: / / \mathrm{www}$. whitehouse.gov/nsc/waronterror/2006/sectionIII.html>.

${ }^{168}$ Lyotard, Gaming 45.

${ }^{169}$ Bull, Anarchical 59.
} 
and presupposes knowledge of security "upon which it is to intervene and/or which it is calculated to bring into being. The common axiom of [the US $A S A$ ] is that an effective power is and must be a power which knows the objects upon which it is exercised ... The condition that [security] must satisfy is that it render reality" amenable to such power. ${ }^{170}$ The US is constantly making statements as to the content and character of international security in a post-9/11 world. Is the US correct in its assertions of the indispensability of US morality, ideology, politics, economy, ideals, and power in the new global context that has emerged? The US $A S A$ treats such statements as unconditionally true. Yet, a statement is not a structure, but rather "a function of existence that properly belongs to the signs and on the basis of which one may decide ... whether or not they 'make sense,' according to what rule they follow one another or are juxtaposed, of what they are the sign, and what sort of act is carried out by their formulation." 171

\section{Terror \& Global Security}

In a post-Cold War world, the global war on terror has effectively replaced the war against communism and the Evil Empire, and retains the hegemonic and expansionist impulse that permeates US policy since at least 1898, when the US entered the SpanishCuban War. Presently,

the US conveys hegemony with new characteristics. These characteristics are described by various authors [as] unilateral hegemony of a new type - one that presupposes interaction with

\footnotetext{
${ }^{170}$ Colin Gordon, afterword, Power/Knowledge: Selected Interviews \& Other Writings 1972-1977, by Michel Foucault, ed. and trans. Colin Gordon (New York: Pantheon, 1980) 245-248.

${ }^{171}$ Michel Foucault, The Archaeology of Knowledge \& the Discourse on Language, trans. Rupert Swyer (New York: Pantheon, 1972) 86-87.
} 
certain allies before acting on its determined imperatives and defines unilateral actions according to its interests ... the US sees itself the unipolar hegemonic power, internationally as well as regionally in the 'new' post-9/11 security context. ${ }^{172}$

Under an absolutist security program, the US forms an entelechy of global security, that is, a complex state of affairs where a large number of objects (states) reside within the confines of defined space (states-system framework). The single object, when combined with other objects, produces an entelechy of order. This is significant because the US $A S A$ is an absolutist, totalizing system, in that security under a terror rubric has an ad infinitum capacity to be expanded and replicated, embodying the directives and interests of the US. Whereas other states may have very different priorities, the US has proclaimed that the "War on Terror remains a generational struggle," and that all nations must be entirely engaged and prepared to participate in this effort. ${ }^{173}$ Security is, therefore, disseminated via self-replicating clusters of ideas, precepts, and first principles backed by overwhelming military power and the specter of the event of $9 / 11$. This manner of positing security for the entire system of states creates tension and conflict rather than security because absolutist security is antithetical to a states system's ordering principles. Recently, US President George W. Bush chastised Russia for failing to meet US standards of proper and necessary social and political development:

In a speech celebrating democracy's progress around the globe-and calling out places where its reach is either incomplete or lacking-Bush said that free societies emerge 'at

\footnotetext{
${ }^{172}$ Marino, "Cuba-US" 191.

173 The White House, National Strategy for Homeland Security October 2007, 19 Aug. $2008<$ http://www. whitehouse. gov/infoc us/homeland/nshs/2007/index.html>.
} 
different speeds in different places' and have to reflect local customs. But he said certain values are universal to all democracies, and rapped several countries for not embracing them. 'In Russia, reforms that once promised to empower citizens have been derailed, with troubling implications for democratic development,' Bush said, speaking at a democracy conference in the Czech Republic - a state that was once part of the former USSR's sphere of influence. ${ }^{174}$

In response, Russia has threatened to militarize at an exponential rate in order to counter what it views as "benevolent" US aggression and encroachment. Under the banner of universal values, states become firmly emplaced within stratified, layered rungs of priority, necessity, as apperceived by the US.

Under the US $A S A$, notions of terror and a US war on terror are implicitly as well as explicitly premised on notions of the "just" that conform to a definition of justice as an axiomatic thing-in-itself. "The distribution of all that circulates in a given society is just if it conforms to something defined ... as justice itself, that is, as the essence, or the idea, of justice." 175 Justice will therefore manifest itself in conformity with specific significations. Symbolic signification, however, possesses a protean capacity; symbols can have different meanings for different actors under different circumstances. ${ }^{176}$ This state of affairs complicates the enterprise of establishing a universal framework of security that is unitary, stable, legitimate, objective, and authoritative. To bypass this difficulty, the US relies upon the "transubstantiation" of US national security and universal justice based on denotative statements. "A just practice will have to conform to

\footnotetext{
174 "Bush: Putin has 'Derailed' Democratic Reforms: President's Comments Risk Stoking Dispute with Russia Over Missile Shield," Associated Press, MSNBC News Online, 5 June $2007<$ http://www.msnbc.msn.com/id/19040836/>.

${ }^{175}$ Lyotard, Gaming 19.

${ }^{176}$ See Alfred North Whitehead, The Aims of Education \& Other Essays (New York: Free Press, 1967) 63.
} 
denotative statements (statements that denote justice) that are themselves true. This is where the pathos of the conviction is involved: it admits that the statement" of the just embodied in security is objectively "true" in and of itself. ${ }^{177}$ Terror as signified and signifier is articulated and implemented via denotative statements. "The vast machine of political thought that justifies itself, or believes itself to be justified, by what it wants to decree in the realm of practice so that a society be just ... all this thought is actually futile, inasmuch as a command cannot find its justification in a denotative statement."178 The success of the US $A S A$ is therefore measured in its inherent truth-value and how effective it is in binding "legitimate" power and control to the order that propagates it. ${ }^{179}$

US statements pertaining to global security policy and the war on terror reveal the operative and ubiquitous structural rules of formation that inform the post-9/11 security context. Conceptual "representation posits the self-identity of the thinking subject. The subject, the concepts, and the objects in the world are thus presumed to share a selfresemblance essential for maintaining their identity. Representational thought establishes a correspondence between two symmetrical domains" that is, US security and global security. ${ }^{180}$ Wittgenstein is correct in noting that the limits of one's language constitute the limits of one's world. ${ }^{181} 9 / 11$ has enabled the US to exponentially develop its

\footnotetext{
${ }^{177}$ Lyotard, Gaming 20.

${ }^{178}$ Lyotard, Gaming 22.

${ }^{179}$ See Louis Althusser, "Ideology and Ideological State Apparatuses: Notes Towards an Investigation," trans. Ben Brester, The Norton Anthology of Theory and Criticism, eds. Vincent B. Leitch, William E. Cain, Laurie A. Fink, Barbara E. Johnson, John McGowan, and Jeffery J. Williams (New York: W.W. Norton, 2001) 1483-1484.

${ }^{180}$ Gilles Deleuze and Felix Guattari, "Kafka: Toward a Minor Literature," trans. Dana Polan, The Norton Anthology of Theory and Criticism, eds. Vincent B. Leitch, William E. Cain, Laurie A. Fink, Barbara E. Johnson, John McGowan, and Jeffery J. Williams (New York: W.W. Norton, 2001) 1595.
}

${ }^{181}$ Wittgenstein, Tractatus 68. 
security apparatuses as well as the powers of the US to actively counter terror in any and all of its manifestations at any cost, financially, politically, legally, and in sacrificing traditional ordering principles. US President G.W. Bush's articulation of the "Bush Doctrine" in his speech at West Point Military Academy (2002) and the New National Security Strategy 2002 are exemplary of this. According to S.C. Marino, "This doctrine is at the margin of both international law and the rules and practices of recognized international norms. It legalizes the hegemonic power's preventive attacks, couched in hypothetical moralizing rhetoric about the necessity of regime change and has, at its core, geo-economic and geopolitical considerations." 182

The modus operandi of post-9/11 global security policy is its unilateral, militaristic, legal, and preemptive character. The US unilaterally marshals material and intangible resources for the defense of "universal" global values and interests. There is no question of legitimacy or authority; there is only the "fact" that there is a distinct, correct way to combat the threat that looms over every state actor (terror), that is, by all states contributing to the security of the US Homeland. Various policies have been put into effect on the international level to make this a reality-policies which arrogate the power to inform if not define all states' security interests, such as:

-The US has used the Financial Action Task Force (FATF) to promote international standards and is helping develop FATFstyle regional bodies to support implementation of these standards, including most recently the Middle East/North Africa Financial Action Task Force and the Eurasian Group to Combat Money Laundering and Terrorist Financing.

182 Marino, "Cuba-US" 193. 
-The US, in partnership with the International Maritime Organization and the International Civil Aviation Organization, has developed and promoted standards for international transport security, including travel document security and biometric identification.

-In June 2004, the G-8 adopted, and implemented, the Secure and Facilitated International Travel Initiative (SAFTI), which focused on developing practices and mechanisms to increase impediments to terrorists' travel.

-The US has worked with the UN Terrorist Prevention Branch (TPB), European Union (EU), and OSCE to encourage enactment of strong counterterrorism laws and to develop common standards and procedures to reduce terrorist exploitation of international travel.

-Through centers like the Southeast Asia Regional Center for Counterterrorism in Malaysia and the US-sponsored International Law Enforcement Academies in Thailand, Botswana, Hungary, El Salvador, and the US the US is providing counterterrorism training to law enforcement officers.

- Since FY 2005, the Department of Defense has exercised new authority to build the capacity of our foreign partners to conduct internal security counterterrorist operations.

-The US has launched an African Maritime Governance Initiative (AMGI) to work in partnership with African countries to improve governance of their maritime space through programs that promote coastal and maritime security awareness and capability.

-Through the provision of training, equipment, and other assistance, the US is building the capacity of foreign partners to attack and defeat terrorists, by strengthening their ability to conduct law enforcement, financial, regulatory, intelligence, and military activities. ${ }^{183}$

An imperative issued from an authority "requires that anyone who [follows] the proposition it is contained in, can make it his or her own ... it must be thought that it is

\footnotetext{
${ }^{183}$ The White House, 9/11 Five Years Later: Successes and Challenges September 2006, 2I Aug. $2008<\mathrm{http} / / \mathrm{www}$. whitehouse.gov/nsc/waronterror/2006/sectionVII.html>.
} 
universalizable for any and every pragmatic context, that is, for any and every move." The US ASA produces a discourse that is "accepted on [its] own merits and positioned within an anonymous and coherent conceptual system of established truths and methods of verification." 185 Since $9 / 11$, the US has defined illimitable terrorism-a terrorism that is as all encompassing, shapeless, potent, and miasmic - as the enemy of global order.

In addition to al-Qaida, a host of other groups and individuals also use terror and violence against the innocent in pursuit of their objectives and pose potential threats to the security of the US. These include Lebanese Hizballah, which has conducted anti-US attacks outside the US ... Hizballah may increasingly consider attacking the Homeland if it perceives the US as posing a direct threat to the group or Iran, its principal sponsor. The US also is not immune to the emergence of homegrown radicalization and violent Islamic extremism within its borders. The terrorist threat to the Homeland is not restricted to violent Islamic extremist groups. We also confront an ongoing threat posed by domestic terrorists based and operating strictly within the US. Often referred to as 'single-issue' groups, they include white supremacist groups, animal rights extremists, and ecoterrorist groups, among others. ${ }^{186}$

Terrorism constitutes the nucleus of an absolutist US security agenda. Terror as an epistemic category is so malleable under the US $A S A$ that animal rights and environmental groups can be logically and justifiably placed in the same category or level as suicide bombers. This can transpire licitly, so to speak, because the US ASA is intimately "tied to the legal and institutional systems that circumscribe, determine, and

\footnotetext{
${ }^{184}$ Lyotard, Gaming 55.

${ }^{185}$ Michel Foucault, "What is an Author?" trans. Donald F. Bouchard and Sherry Simon, The Norton Anthology of Theory and Criticism, eds. Vincent B. Leitch, William E. Cain, Laurie A. Fink, Barbara E. Johnson, John McGowan, and Jeffery J. Williams (New York: W.W. Norton, 2001) 1628.

186 The White House, National Strategy for Homeland Security October 2007, 19 Aug. $2008<$ http://www. whitehouse. gov/infoc us/homeland/nshs/2007/index.html>.
} 
articulate the realm of discourses; it does not operate in a uniform manner in all discourses, at all times[;] it is not defined by the spontaneous attribution of a text to its creator, but through a series of precise and complex procedures" that revolve around illimitable, polymorphous terror and global security. ${ }^{187}$ The war on terror is

general enough to support more than one meaning. It can be interpreted precisely, in terms of destroying the organizations and instruments of terror, and protecting the homeland against [WMD] theft efforts. But it can also be defined much more broadly to encompass changing the conditions that gave rise to terrorism, and creating an international order that would be inimical to its existence ... [establishing] conceptual boldness and an ambitious, assertive use of American power. ${ }^{188}$

Yet, as Robert Kagan notes, "America did not change on $9 / 11$. It only became more itself." ${ }^{\prime 189}$ While the event of $9 / 11$, terror, and the $9 / 11$ war-response are indeed new policies/ frameworks, US aspirations for world dominance and the "blowback" that the US experienced on $9 / 11$ as a direct consequence of pursuing global dominance is nothing novel, surprising, or unforeseeable. For the US, "by its unbearable power, has fomented [terrorist] violence which is endemic throughout the world," fueling the "terroristic" imagination. ${ }^{190}$ Indeed, from the founding until the present, the US has always envisioned itself playing a profound role in the history of all nations: there is a messianic, hegemonic, and imperialist continuity between the Monroe Doctrine (1823),

\footnotetext{
${ }^{187}$ Foucault, “Author” 1631.

${ }^{188}$ Owen Harries, "Australia \& the Bush Doctrine: Punching Above Our Weight?" Confronting the Bush Doctrine: Critical Views From the Asia-Pacific, eds. Mel Gurtov and Peter Van Ness (London: Routledge-Curzon. 2005) 229.

${ }^{189}$ Robert Kagan, Paradise and Power: America and Europe in the New World Order (London: Atlantic Books, 2003) 88 .

${ }^{190}$ Baudrillard, Spirit 5.
} 
Wilsonian International Liberalism (1900s), the Truman Doctrine (1947), the Regan Doctrine (1980s), G.H. Bush's New World Order (1990s), and the G.W. Bush Doctrine (2001-present), to name a few significant exemplars. "The US's conviction that its interests and the world's interests are one ... may be welcomed, ridiculed, or lamented. But it should not [and cannot] be doubted." ${ }^{\prime 191}$ In light of the historical record, 9/11 runs along the same track as the previous doctrines/frameworks listed; the difference lies in 9/11's significance, scope, interpretation, unilateral implementation, and there being lack of any power to effectively counter or ballast US power. Hence, the US can authoritatively, legitimately, and categorically establish, in the name of $9 / 11$ and its security interests, the following advances in "combating" the terrorist threat to global security:

The US has advanced efforts in the international community to deny safe haven and material support to terrorists. The US will continue to insist that all state sponsors end support and sanctuary to terrorists [and will] implement sanctions against, and promote international isolation of, state sponsors ... At the same time, we will continue to work with allies in the War on Terror to strengthen their ability to destroy safe havens [For example,] the US has:

- Helped create the Yemeni Coast Guard, bolstered Yemen's counterterrorism forces, worked to reduce the illicit flow of small arms and light weapons, and strengthened Yemeni border security and export control measures.

- Cooperated closely with regional partners to interdict arms flows and monitor terrorist activities through the East Africa Counterterrorism Initiative (EACTI). EACTI provides assistance, including border security and police training, to Comoros, Djibouti, Eritrea, Ethiopia, Kenya, Madagascar, Tanzania, and Uganda.

\footnotetext{
${ }^{191}$ Kagan 88.
} 
- Through the Trans-Sahel Counterterrorism Initiative (TSCTI), provided military support and other assistance to Chad, Mali, Niger, Mauritania, Algeria, Morocco, Nigeria, Senegal, and Tunisia to enhance cooperation among the region's security forces.

-In Indonesia, provided capacity-building training to the national police and law enforcement counterterrorism personnel to reinforce efforts to detect, disrupt, and dismantle terrorist networks.

-In FY 2005, the Department of State's Antiterrorism Assistance (ATA) Program provided training and technical assistance to 78 countries. Seventy-five countries were scheduled to receive ATA training through the end of FY 2006.

-Implemented the Regional Strategic Initiative (RSI), to develop flexible regional networks in key terrorist theaters of operation to assess the threat and devise collaborative strategies, actionable initiatives, and policy recommendations.

-With UNSCR 1267, and its successor resolutions including UNSCR 1617, the UN has required Member States to impose travel restrictions and arms embargo against Osama bin Laden, the Taliban, al-Qaida, and those associated with them and to freeze their financial assets.

-Drafted and co-sponsored UNSCR 1373, which requires all States to deny safe haven and prevent the movement of terrorists across borders. The Resolution also mandates all States to prevent and suppress terrorist financing by requiring states to criminalize terrorist financing, planning, preparing, or perpetrating terrorist acts. ${ }^{192}$

Rules of conduct and reality-formation create epistemic and conceptual foundations for exclusion, inclusion, and circumscription when it comes to comprehending global order. ${ }^{193}$ Indeed, rules of formation are a primary means by which the US seeks to make "true" the interests, values, morality, and priorities of its order-

\footnotetext{
192 The White House, 9/11 Five Years Later: Successes and Challenges September 2006, 22 Aug. 2008 $<$ http://www.whitehouse .gov/nsc/waronterror/2006/sectionVI.html>.

${ }^{193}$ Foucault, Archaeology 25. Also, see James N. Rosenau, "Pre-Theories and Theories of Foreign Policy," Approaches to Comparative and International Politics, ed. R. Barry Farrell (Evanston: Northwestern University Press, 1966) 27-93.
} 
combine. While the US practices forms of "multi-layered geo-governance," the cynosure of security, that is, terror and rules of formation that articulate terror, seek to establish the conditions of existence, coexistence, maintenance, and modification in defining the content of global security and society. ${ }^{194}$ Arrangements of order prescribe rules of reality-comprehension, modalities of existence. Within such a milieu, security finds expression in governance. The US $A S A$, the war on terror, and the Bush Doctrine ignore the states system and international society, and concomitantly create a this/that universe while also retaining a nebulous quality as far as defining what is a security threat. There are no clear rules of formation; what the US deems threatening and terrorist in nature is targeted for elimination. Notions of terror are "constituted by differences and by differences from differences, it is by its nature absolutely heterogeneous and is constantly composing with the forces that tend to annihilate it," that is, the enemies of global peace, security, and freedom. ${ }^{195}$ In waging an aggressive militaristic, absolutist war against terror, the imperial hegemon's system of security and peace, a pax imperium/hegemonia, after 9/11 reflects the tremendous power to articulate and execute the rules of formation as far as what and what does not qualify as a legitimate state actor and threat to global peace. Peace, however, should not be confused with justice. ${ }^{196}$ "Peace and justice are not natural allies, unless right happens to coincide with might."197

\footnotetext{
${ }^{194}$ Bull, Anarchical xvii; Foucault, Archaeology 38.

195 Jacques Derrida, "Dissemination: Plato's Pharmacy," trans. Barbara Johnson, The Norton Anthology of Theory and Criticism, eds. Vincent B. Leitch, William E. Cain, Laurie A. Fink, Barbara E. Johnson, John McGowan, and Jeffery J. Williams (New York: W.W. Norton, 2001) 1849.

196 Richard K. Betts, "The Delusion of Impartial Intervention," Conflict After the Cold War: Arguments on Causes of War \& Peace $2^{\text {nd }}$ ed., ed. Richard K. Betts (New York: Pearson Lorıman, 2005) 606.

${ }^{197}$ Betts, "Delusion" 606.
} 
Based on the 9/11 attacks, a global war of unprecedented scope was officially declared and initiated by the US on a material as well as an ideational level. After the attacks, US President G.W. Bush emphatically declared, "They have declared war on us ... we are going to war," one in which the US "will make no distinction between the terrorist who committed [the] acts and those who harbor them." "198 Given that the world is divided into nation-states, the logical derivative of a key principle under-girding the war on terror is that the war has no boundaries, and neither does the application of US power in attempts to eradicate anything and everything that falls under the rubric of a polymorphous enemy. "Terror" is, therefore, signifier and signified, and can be "found" in any form of (violent) resistance.

Terrorism has historically been and continues to be a viable form of resistance by actors that are too weak to challenge a perceived threat/enemy. With $9 / 11$, terrorism has "changed," in that the terrorists that committed the $9 / 11$ attacks

\begin{abstract}
brought their own deaths to bear in an effective, offensive manner, in the service of an intuitive strategic insight which is quite simply a sense of the immense fragility of the opponent - a sense that a [unipolar] system which has arrived at its quasiperfection can, by that very token, be ignited by the slightest spark. They have succeeded in turning their own deaths into an absolute weapon against a system that operates on the basis of exclusion of death, a system whose ideal is an ideal of zero deaths ... And all the means of deterrence and destruction can do nothing against an enemy who has already turned his death into a counterstrike weapon. ${ }^{19 \%}$
\end{abstract}

\footnotetext{
${ }^{198}$ George W. Bush quoted in Bob Woodward, Bush At War (New York: Simon \& Shuster, 2002) 15; George W. Bush, "Statement by the President in His Address to the Nation," The White House, Washington, D.C., 11 Sept. 2001, 14 June 2007 <www.whitehouse.gov/news/releases/2001/09/20010911-16.html>. See Russell D. Howard, Reid L. Sawyer, and Natasha E. Bajema, Terrorism and Counterterrorism: Understanding the New Security Environment, Readings and Interpretations 3 ed. (New York: McGraw-Hill/Dushkin, 2008).

${ }^{199}$ Baudrillard, Spirit 16.
} 
The US interpretation of $9 / 11$ dispenses with external motives and justifications. The sundry motives for terror are peripheral, marginalized. Terror is a MSL that follows a self-contained and autonomous logic, involving a category of knowledge that is the "expression and communication of ... social experience, culturally determined in space and time."200 The terrorist act itself, which is categorically criminalized, is culturally defined. Criminalization of the act, with no or nominal weight accorded to motives, preempts any "legitimate" analysis, critique, and/or understanding of the "why" of terror, of the political, ideological, social, cultural, historical, and economic motives for terrorist acts. After 9/11, terror laid the groundwork for an objective, absolutist, aggressive, preemptive, and preventive security policy. ${ }^{201} 9 / 11$ and the specter of terror it ushered in was viewed as part of malevolent trend as opposed to an isolated or explainable act.

After the 9/11 attacks, US President George Bush declared, "this crusade, this war on terrorism, is going to take awhile," and that while some may not find it "diplomatic to speak of 'good and evil' ... I feel like I represent how the American people feel."202 That bin Laden, the visage of terrorist evil, specifically stated that "to kill Americans and their allies, both civil and military, is an individual duty of every Muslim who is able, in any country where this is possible," seems to provide prima facie evidence for the utility of an absolutist security policy. ${ }^{203}$ Yet, morality aside, the rhetoric and actual waging of

\footnotetext{
${ }^{200}$ Bertalanffy, Systems View 51.

${ }^{201}$ See John W. Dietrich, ed., The George W. Bush Foreign Policy Reader: Presidential Speeches With Commentary (New York: M.E. Sharpe, 2005) 39.

${ }^{202}$ George W. Bush quoted in Todd S. Purdum "Bush Warns of Wrathful, Shadowy and Inventive War," New York Times, 17 Sept. 2001; George W. Bush quoted in Bill Scammon, Fighting Back: The War on Terror From Inside the White House (Washington, D.C.: Regnery Press, 2002) 335.

203 "Declaration of the World Islamic Front for Jihad Against the Jews and the Crusaders," quoted in Bernard Lewis, "License to Kill: Usama bin Ladin's Declaration of Jihad," Foreign Affairs 77 (Nov/Dec 1998) 14-15.
} 
asymmetrical warfare by weaker powers/ actors have been manifested in international order since its inception. Furthermore, it can be argued that absolutism has produced conditions that have, in turn, presented a profound challenge to US power. For instance, the following rational exemplars can be interpreted as fueling "senseless" terrorist evil: a massive military presence/occupying force in the Middle East; levying sanctions against "undesirable" regimes; marginalizing, dismissing, and/or criminalizing other forms of governance not in line with US prerogatives; unilateral invasion of sovereign states; impinging upon states' sovereignty by exerting unabashed influence/control over Middle East political and economic policies; and categorical ideological, political, military, financial, and unqualified economic support of Israel by the US for geo-political and strategic purposes.

The 9/11 attacks are presented as ubiquitous, as threatening the very fabric of international society. Terrorism is the embodiment of universal evil, and is given universal symbolic and material content by the US $A S A$. All states and peoples are affected by the terrorism experienced by the US on $9 / 11$.

[President] Bush compared the terrorists directly to the previous era's totalitarians, arguing that they seek to control every aspect of life and impose their views through violence ... Bush argued that no country could be neutral in this conflict: all had to choose between radicalism and freedom, between support for terrorism and support for civilization, between evil and good. ${ }^{204}$

The "Bush Doctrine" and its emphasis on waging an absolutist war on terror presents a variety of problems, both conceptual and pragmatic, such as the following.

${ }^{204}$ Dietrich 42. 
1., sweeping rhetoric that defines the world in black and white terms limits options; 2., linking efforts to a grand cause can lead to public disillusionment in the overall cause when setbacks occur; 3., an activist US may be perceived by other countries as an international bully; 4., declaring terrorism to be the number one problem could shift attention away from other issues or skew debates on other important policy goals; 5., the policy-making system may become too driven by the executive branch, which tends to assert power in times of national crises. ${ }^{205}$

The war on terror, terror, and the Homeland are systemic categories that, in rhetoric and application, are US-defined, US-driven, and US-managed/organized. "Symbolic forms or categories are neither a passive framework of innate a prioris as Kant assumed, nor are they acquired by simple repetition as Hume ... contended; [rather,] they are creative functions of the individual mind and culture concerned." ${ }^{206}$ Nation-states that are normal, rational, civilized, and/or suitable for the US-managed international system of states are permitted and encouraged to join the US in its crusade, in planning what international society will look like. According to US President George W. Bush, "Every nation has a stake in this cause," and even though "at some point, [the US] may be the only [state] left[, that is] okay ... We are America." ${ }^{207}$ Under a war-on-terror rubric, war is premised on a conflict between values, morality, civilization, and the proper universal paradigm for international affairs. The $9 / 11$ attacks have been invested with more than mere repugnance of violence. Violence in and of itself, outside of US rules of formation, has been construed as maniacal, nefarious, an unpardonable assault on the global polity

\footnotetext{
${ }^{205}$ Dietrich 42.

${ }^{206}$ Bertalanffy, Systems View 60.

${ }^{207}$ George W. Bush, speech, UN General Assembly, New York, NY, 10 Nov. 2001, The George W. Bush Foreign Policy Reader: Presidential Speeches With Commentary, ed. John W. Dietrich (New York: M.E. Sharpe, 2005) 5051;Bob Woodward, Bush at War (New York: Simon \& Schuster, 2002) 81.
} 
(which is a direct extension of the US). The use of violence by enemies of global peace and freedom is construed as a clear struggle between the forces of good and evil, as freedom versus slavery, as compulsory ethical resistance against tyranny, totalitarianism, fear, authoritarianism, and the like. Yet violence is an immanent and constituent component of human affairs. How to draw clear, objective lines between destruction and construction, unwarranted and necessary aggression, justified and unjustified violence?

In light of $9 / 11$, any form of violent resistance that violates US morality, sensibilities, or interests is inherently "evil." According to the US, "On September the $11^{\text {th }}$ enemies of freedom committed an act of war against the [US] ... in a single day ... night fell on a different world, a world where freedom itself is under attack."208 Freedom, like power, is a complex and problematic state of affairs. There is no self-evident, objectively correct notion of "true" freedom. What qualifies as a "free" state of affairs? Does freedom involve the obligation to consume, a commitment to profit and materialism, an obligation to obey and stalwartly uphold the political, social, and economic imperatives of the US state? In what manner is it proper to construe and define a universal notion of freedom? Under whose auspices is freedom legitimately articulated and implemented? Is there no other (legitimate) framework whereby to conceptualize security besides a uni-dimensional, binary Freedom versus Terror framework?

Internationalizing the War on Terror

To emplace war within such a rubric is to wage unlimited war on anything that does not comport with relativistic notions of a "freedom" that has a singular definition. It

\footnotetext{
${ }^{208}$ George W. Bush, speech, US Capitol, Washington, D.C., 20 Sept. 2001, The George W. Bush Foreign Policy Reader: Presidential Speeches With Commentary, ed. John W. Dietrich (New York: M.E. Sharpe, 2005) 50-51.
} 
is not possible to conceive that forcibly imposing "freedom" is perhaps analogous to the stated goal of terror, that is, to remake the world by imposing "beliefs on people everywhere."209 To combat ubiquitous terror, the US has internationalized its war.

the US will pursue nations that provide aid or safe haven to terrorism. Every nation, in every region, now has a decision to make. Either you are with us, or you are with the terrorists ... the only way to defeat terrorism as a threat to our way of life is to stop it, eliminate it, and destroy it where it grows ... This is not ... just America's fight. And what is at stake is not just America's freedom. This is the world's fight. ${ }^{210}$

To destroy terror "where it grows" lends itself to a destabilizing "clash of civilizations" framework. ${ }^{211}$ The clash of civilizations, in thought and practice, supports an "objective" Us versus Them framework for comprehending terror and violent opposition to US power. According to the US, "civilization, itself, the civilization we share, is threatened. History will record our response, and judge or justify every nation. We ... choose the dignity of life over a culture of death ... every nation in our coalition has duties" to carry out the mandates of US security policy. ${ }^{212}$ Yet, the US characterization of $9 / 11$ initiating a world war to preserve the existence and survival of Western is dubious at best. ${ }^{213}$

\footnotetext{
${ }^{209}$ George W. Bush, speech, US Capitol, Washington, D.C., 20 Sept. 2001, The George W. Bush Foreign Policy Reader: Presidential Speeches With Commentary, ed. John W. Dietrich (New York: M.E. Sharpe, 2005) 51.

${ }^{210}$ George W. Bush, speech, US Capitol, Washington, D.C., 20 Sept. 2001, The George W. Bush Foreign Policy Reader: Presidential Speeches With Commentary ed. John W. Dietrich (New York: M.E. Sharpe, 2005) 53.

${ }^{211}$ Samuel P. Huntington, The Clash of Civilizations \& the Remaking of World Order (New York: Touchstone, 1996).

${ }^{212}$ George W. Bush, speech, United Nations General Assembly, New York, NY, 10 Nov. 2001, The George W. Bush Foreign Policy Reader: Presidential Speeches With Commentary ed. John W. Dietrich (New York: M.E. Sharpe, 2005) 56.

${ }^{213}$ See Chalmers Johnson, Nemesis: The Last Days of the American Republic (New York: Holt, 2006).
} 
An example of 9/11 finding international expression can be observed in the role the UN has played in internationalizing the war or terror. In 2005, the UN Security Council adopted two resolutions to support the war on terror. Resolution 1617 strengthened extant sanctions against the Taliban and al-Qaida, and endorsed the establishment of the Financial Action Task Force standards for combating international money laundering and terrorist financing. Resolution 1624, adopted at a Security Council summit, specifically addressed the issues of incitement to terrorism and terrorist safe havens. Also, the Counterterrorism Committee (hereinafter, CTC) was established by National Security Council Resolution 1373 after the $9 / 11$ attacks, with the aim of "raising the performance level of the governments of all 191 member states in the fight against terrorism." ${ }^{214}$ The CTC's Executive Directorate (hereinafter, CTED), established in 2004, enhances the Committee's ability to monitor the implementation of Resolution 1373 and to "continue its capacity-building work by facilitating technical assistance to member states and promoting closer cooperation and coordination with international, regional, and sub-regional organizations. It is also undertaking visits to certain nations to assess their implementation of obligations under Resolution 1373."215 The Security Council also "maintains a list of individuals and entities associated with al-Qaida, the Taliban, and/or [Osama] bin Ladin that are subject to international sanctions-assets freeze, travel ban, and arms embargo- that member states are obligated to implement.",216

\footnotetext{
${ }^{214}$ US Department of State, Country Reports on Terrorism, Office of the Coordinator for Counterterrorism 28 April 2006, 23 June $2007<\mathrm{http}: / / w w w . s t a t e . g o v / \mathrm{s} / \mathrm{ct} / \mathrm{rls} / \mathrm{crt} / 2005 / 66236$. htm>.

${ }^{215}$ US Department of State, Country Reports on Terrorism, Office of the Coordinator for Counterterrorism 28 April 2006, 24 June $2007<\mathrm{http}: /$ www.state.gov/s/ct/rls/crt/2005/66236.htm>.

216 US Department of State, Country Reports on Terrorism, Office of the Coordinator for Counterterrorism 28 April 2006, 24 June $2007<$ http://www.state.gov/s/ct/rls/crt/2005/66236.htm>.
} 
The Financial Action Task Force on Money Laundering (hereinafter, FATF), established in 1989, is an inter-governmental body charged with developing global standards and policies aimed at combating money laundering and, following the $9 / 11$ attacks, financing terrorism. FATF's recommendations are acknowledged as the international standards of the US-managed global system in both these areas, and serve as the basis of regular evaluations of its members' financial sectors as well as evaluations by the IMF and World Bank. "In 2002, the FATF adopted eight (later nine) special recommendations on terrorist financing. While focused principally on safeguarding the integrity of the international financial systems, these recommendations also provide governments with guidance on combating terrorist misuse of cash couriers, wire transfers, and non-profit organizations." 217 In addition, the UN's Outcome Document issued "a clear and unqualified condemnation of terrorism "in all its forms and manifestations, committed by whomever, wherever, and for whatever purposes,' and sets objectives for UN actions to counter terrorism," and seeks "the adoption and implementation of a comprehensive strategy to promote comprehensive, coordinated, and consistent responses at the national, regional, and international level." ${ }^{218}$ The UN has also adopted antiterrorism resolutions, established the Comprehensive Convention on International Terrorism, and concluded the International Convention for the Suppression of Acts of Nuclear Terrorism. ${ }^{219}$

\footnotetext{
${ }^{217}$ US Department of State, Country Reports on Terrorism, Office of the Coordinator for Counterterrorism 28 April 2006, 24 June $2007<\mathrm{http}: / / \mathrm{www}$. state.gov/s/ct/rls/crt/2005/66236.htm>.

${ }^{218}$ US Department of State, Country Reports on Terrorism, Office of the Coordinator for Counterterrorism 28 April 2006, 22 June $2006<\mathrm{http}: / / \mathrm{www}$. state.gov/s/ct/rls/crt/2005/66236.htm>.

${ }^{219}$ US Department of State, Country Reports on Terrorism, Office of the Coordinator for Counterterrorism 28 April 2006, 22 June $2007<\mathrm{http}: / /$ www.state.gov/s/ct/rls/crt/2005/66236.htm>.
} 
The international nature of the war on terror has produced an international hegemonic security agenda. Terror, in the abstract as well as empirically, becomes the all-encompassing enemy, creating centers of terror whose reach and significance are only limited by the inventive imagination of the imperial hegemon. The following chapters will, therefore, explore select case studies, that is, the USA Patriot Act, WMD proliferation, and the rogue state of North Korea, as empirical manifestations of an $A S A$ rubric in post $9 / 11$ global security context. 
The USA PATRIOT Act 2001, that is, the Uniting and Strengthening America by Providing Appropriate Tools Required to Intercept and Obstruct Terrorism Act of 2001 (hereinafter, $P A$ ), is an example of how $9 / 11$ has been utilized to push for an $A S A$ that legally posits US national security as the controlling standard for international security. ${ }^{220}$ An examination of the linkage between legality, criminality, terror, and security within a domestic juridical framework illuminates the post-9/11 security context. Law is particularly relevant when one considers that US power is premised upon the notion that international society should be subject to an objective rule of law. Law is a means by which US domestic security can be invested with a truth-value beyond (legitimate) question. When considering law and power, it must be kept in mind that power "is exercised through networks, and [actors] do not simply circulate in those networks; they are in a position to both submit and exercise this power. They are never the inert or consenting targets of power ... power passes through [actors]. It is not [necessarily] applied to them.",221 Knowledge and truth are produced and reified by security measures and the order-combine they devolve from. Legality therefore functions as a means of producing and reflecting US security priorities at the expense of competing priorities, such as civil liberties and state sovereignty. The US articulates a specific set of values, prerogatives, principles, and morals when it utilizes law to enhance its power. Since the

\footnotetext{
${ }^{220}$ UNITING AND STRENGTHENING AMERICA BY PROVIDING APPROPRIATE TOOLS REQUIRED TO INTERCEPT AND OBSTRUCT TERRORISM ACT OF 2001, PUBLIC LAW 107-56 [H.R.3162] 26 OCT 2001, 107 P. L. 56; 115 Stat. 272; 2001 Enacted H.R. 3162; 107 Enacted H.R. 3162, 12 August $2007<\mathrm{http}: / /$ web.lexisnexis.com.ez proxy.fiu.edu/congcomp/document? $\mathrm{m}=1 \mathrm{~cd} 1193 \mathrm{c} 5 \mathrm{e} 82 \mathrm{a} 79765 \mathrm{a} 3143 \mathrm{c} 9728537 \mathrm{a} \&$ doc num=1\&wchp=dGLbVtz-zSkS A\&_md5=9ff964e9b9fd4 e 55efd3b2 99d1991e69>.

${ }^{221}$ Foucault, Society 29.
} 
post-WWII period, the US holds itself out as the "unitary power that maintains the social peace and produces ... ethical truths" for the international community. ${ }^{222}$

In light of the war on terror, the PA exemplifies a security system's capacity to become an overtly boundless security measure, uniting "juridical categories and universal ethical values, making them work together as an organic whole."223 The PA posits a framework of security that, at a most basic level, should prompt us to examine the essence of post-9/11 global security. As Geoffrey Blainey observes,

For any explanation the framework [utilized] is crucial. In every field of knowledge the accepted explanations depend on the marshalling of evidence than on preconceptions of what serves as a logical framework for the evidence. The framework dominates the evidence, because it dictates what evidence should be sought or ignored. Our idea of a logical framework is often unconscious, and this elusiveness enhances its grip. ${ }^{224}$

Security as articulated in the PA explicitly privileges, prioritizes, US security as the basis for global security; the PA blurs the demarcation between domestic and international categories of security. According to the US, the system of states must embrace its $A S A$ as the only logical means to combat "terror."

In the face of this ruthless threat [of terrorism], our nation has made a clear choice: We will confront this mortal danger, we will stay on the offensive, and we're not going to wait to be attacked again. Since September the 11th, 2001, we have taken the fight to the enemy. We've hunted terrorists in the mountains

\footnotetext{
${ }^{222}$ Michael Hardt and Antonio Negri, Empire (Cambridge: Harvard University Press, 2000) 10.

${ }^{223}$ Hardt, Empire 10.

${ }^{224}$ Blainey, "Power" 114.
} 
of Afghanistan, cities of Iraq, the islands of Southeast Asia, and everywhere else they plot, plan, and train. Our men and women in uniform have brought down two regimes that supported terrorism. We liberated 50 million people. We've gained new allies in the war on terror. As we wage the war on terror overseas, we're also going after the terrorists here at home, and one of the most important tools we have used to protect the American people is the Patriot Act. The Patriot Act closed dangerous gaps in America's law enforcement and intelligence capabilities, gaps the terrorists exploited when they attacked us on September the 11 th. ${ }^{225}$

The establishment of "legally definable enemies"-which one is obligated to consider "legitimate" - is a security strategy that enables the projection of US security policy and interests to form the singular and ubiquitous legal basis for global security. ${ }^{226}$ While the US has a long tradition of projecting its security interests and policy across the globe, the PA indicates a change in policy in that US domestic security is now explicitly postulated as being synonymous with world security, and is disseminated via a domestic legal instrument. Distinctions between "sovereign" states-a conceptual cornerstone of international relations-become subsumed under a totalizing rubric of security that is premised upon a universal (yet domestic/national) definition of justice. The PA reflects the US "empire of thought" regarding US control of setting the global security agenda. In 1943, Winston Churchill made a very insightful observation regarding the future of imperial power: "The empires of the future ... are the empires of the mind ... [Empire]

\footnotetext{
${ }^{225}$ George W. Bush, speech, "President Signs USA PATRIOT Improvement and Reauthorization Act," The White House, East Room, 9 March 2006, 29 June $2007<$ www.whitehouse.gov/news/releases/2006/03/20060309-4.html>. Also, see Patrick Leahy, THE UNITING AND STRENGTHENING AMERICA BY PROVIDING APPROPRIATE TOOLS REQUIRED TO INTERCEPT AND OBSTRUCT TERRORISM (USA PATRIOT) ACT OF 2001, H.R. 3162 SECTION-BY-SECTION ANALYSIS, 29 June 2007 <http://leahy.senate.gov/press/200110/102401a.html>.

${ }^{226}$ See Charles A. Flint, "Challenging the Legality of Section 106 of the USA PATRIOT Act," 67 Alb. L. Rev. 1138. Albany Law Review (2004), 5 Jan. $2007<$ http://web.lexis-nexis>; Walter M. Brasch, America's Unpatriotic Acts: The Federal Government's Violation of Constitutional and Civil Rights (New York: Peter Lang Publishing, 2005).
} 
does not covet territory or resources. It covets ideas."227 By imposing its idea of global security via an "objective" medium (law), the US augments its global power.

\section{Enemies of Freedom}

The PA wages war on a variety of levels against global enemies of freedom by blurring "the boundary between internal and external security concerns." ${ }^{228}$ At root, the PA is part of a grand war on the level of ideas. "The war on terrorism is at root a war of ideas. As Secretary [of Defense,] Donald Rumsfeld explained in 2003, 'all elements of national power: military, financial, diplomatic, law enforcement, intelligence and public diplomacy,' are necessary to win the war on terror. But, he added, 'to win the war on terror, we must win the war of ideas." 229 The PA, therefore, wages a legalistic war against terror, combining ideas and force into a comprehensive strategy of perpetuating US power. The US, for example, in the name of security has given itself the power to maintain records of any “information used to verify a person's identity, including name, address, and other identifying information. ${ }^{, 230}$ Privacy, as idea and in practice, succumbs to the US interest of protecting and perpetuating the inviolability of the state. The PA is revealing of the tension, dissonance that exists between PA security and individualism (a core component of American political philosophy), and the state's interest in effacing the priority of individual freedom as well as the diversity of states' security interests that

\footnotetext{
${ }^{227}$ Bradley A. Thayer, "The Case for the American Empire," American Empire: A Debate, Bradley A. Thayer and Christopher Layne (New York: Routledge, 2007) 7.

${ }^{228}$ David Campbell, Writing Security: United States Foreign Policy and the Politics of Identity (Minneapolis: University of Minnesota Press, 1998) 27.

${ }^{229}$ Donald Rumsfeld, "Take the Fight to the Terrorists," Washington Post, 26 October 2003, B-7.

${ }^{230}$ Patriot Act 39.
} 
exist on the world stage. To attain security, the US must subordinate the very basis of its power, that is, the individual subject, as well as the states system within which it functions. The security measures enunciated in the PA have the effect of perpetuating an order-combine that infiltrates and functions via enhanced state surveillance, arrest, detention, spying, defining threat and security, and intelligence gathering measures free from extensive oversight and accountability.

The US preoccupation with control, with ordering the world in its image and according to its particular security interests, has the effect of fueling its unipolar security impulse, equipping it (the state and its security discourse) with a "licit" means of counteracting any "threat" (real or imagined) that may present itself. Via a legal dissertation of knowledge the US juxtaposes itself against and infiltrates/assimilates the individual state actors of the world system. By engaging in such practices, the US ASA seeks to circumvent the notion that there may be a limit to the virtuosity of security measures. PA security measures are devised to act upon any event, information, practice, actor, etc., deemed to constitute or imply any "actual or potential attack or other grave hostile acts of [any] foreign power or an agent of a foreign power" against the US. ${ }^{231}$ Section 501 of the PA, for example, authorizes the FBI to "make an application for an order requiring the production of any tangible things (including books, records, papers, documents, and other items)" for investigation to protect against international terrorism or clandestine intelligence activities, with the express legal authority to conduct surreptitious investigations. ${ }^{232}$ An order so obtained "shall not disclose that it is issued

\footnotetext{
${ }^{231}$ Patriot Act 9.

${ }^{232}$ Patriot Act 15.
} 
for purposes of investigation," and "no person shall disclose to any other person ... that the FBI has sought or obtained tangible things."233 The PA can therefore be viewed as an attempt to establish a "network of permanent, [unfettered] observation."234

The power of the US to engage in legal and unfettered clandestine surveillance of its populace and of publics abroad in the pursuit of its security interests has been bolstered, further legitimized, via a legal instrument. Under color of law, the unipolar state expands its power by explicitly grafting its politico-legal and ideological agenda onto global society. ${ }^{235}$ The PA gives a suitable, legitimate legal framework to buttress the US political agenda that under-girds domestic/international security. The US, via measures of summate securitization (surveillance and the authoritative power to discipline and punish), premises its efforts on its providing a ballast, a point of convergence, a means by which the component elements of security and control become a single, unified Security=Control/Control=Security equation. Security, therefore, concomitantly becomes an end in itself and a means to "not only manage [a] territory and a population but also create ... the very world it inhabits. ${ }^{, 236}$

The PA is premised upon the following assertion: it is a juridical "Act to deter and punish terrorist acts in the US and around the world, to enhance law enforcement investigatory tools, and for other purposes" (emphasis added). ${ }^{237}$ The PA establishes

\footnotetext{
${ }^{233}$ Patriot Act 15.

${ }^{234}$ Michel Foucault, "Discipline and Punish: The Birth of the Prison," trans. Alan Sheridan, The Norton Anthology of Theory and Criticism, eds. Vincent B. Leitch, William E. Cain, Laurie A. Fink, Barbara E. Johnson, John McGowan, and Jeffery J. Williams (New York: W.W. Norton, 2001) 1638, 1643.

${ }^{235}$ Althusser 1468.

${ }^{236}$ Hardt, Empire xv.

${ }^{237}$ Patriot Act 1 .
} 
inextricable ties between universal justice and US security. The legitimacy of waging what in essence can be envisioned as an all-encompassing declaration of war is premised upon the equation of: If (if $P$, then $Q$ ), therefore $R$ : that is, if (if a given distribution of security obtains, then justice obtains), therefore justice obtains. ${ }^{238}$ This tautological formulation is at the heart of security as enunciated in the PA. The means, the standards, by which to adjudge the viability, propriety, of a "threat," proceed from the illusion of an elective sensus communis embodied in US security discourse; yet, in actuality, judgments are tinctured with distinct political values and norms. Dissertations of security are "not regulated by categories. History itself provides no help in their formulation."239 US categories of security are part of a system of knowledge that is ubiquitous and amorphous. Criteria of judgment are, as Immanuel Kant posits, "invented." This state of affairs enables the PA to substantiate unilateral warfare against uncongenial international enemies under color of law.

The ambiguous phrase in the PA, "and for other purposes," imbues US security with surfeit degrees of freedom to define and legislate the meaning of global threats. The expansive pronouncements of the PA can be likened to Jeremy Bentham's Panopticon; consummate security measures infuse security with a super-ordinate legitimacy and justification to observe, record, and sanction. The PA is, therefore, a politico-legal instrument that is part of a general war against terror, premised against any form of resistance to the prerogatives of US security. The PA entitles the state (that is, the state authorizes itself) to pursue security at any and all costs. Financially, for instance, the PA

\footnotetext{
${ }^{238}$ Lyotard, Gaming 21.

${ }^{239}$ Lyotard, Gaming 14.
} 
institutes an inexhaustible Counter-Terrorism Fund for the purpose of combating "terror" (decreeing that any costs incurred by officials "paying rewards in connection with" 240 identifying terrorist activities have no limit and shall be reimbursed from the Fund).

The didactic imperative of the PA is decreed applicable to the world at-large. The US's unconditional expenditure of resources in support of both domestic and international anti-terrorist activity is something that all states are expected to emulate. The US and all states should spare no expense and incur "any costs in connection with detaining in foreign countries individuals accused of acts of terrorism that violate the laws of the US." 241 Indeed, the US has declared that, "a regime that has lost its legitimacy [in view of the US] will also lose its power."242 US law has assumed an officious position vis-à-vis international security. States' sovereignty falls to the wayside and US precepts and premises of security reign supreme in the conduct of international relations. The PA universalizes US moral rectitude, declaring that, "the concept of individual responsibility for wrongdoing is sacrosanct in American society, and applies equally to all (emphasis added).,"243

A relentless, ubiquitous, and immoral foe provides grist for the mills of PA securitization, creating a perpetual "urgent and unparalleled need to protect the physical integrity of the nation from any future attacks." ${ }^{244}$ In defining the PA war-response to "terror," the US has erected a continuing-threat matrix upon a trans-mutative terra firma

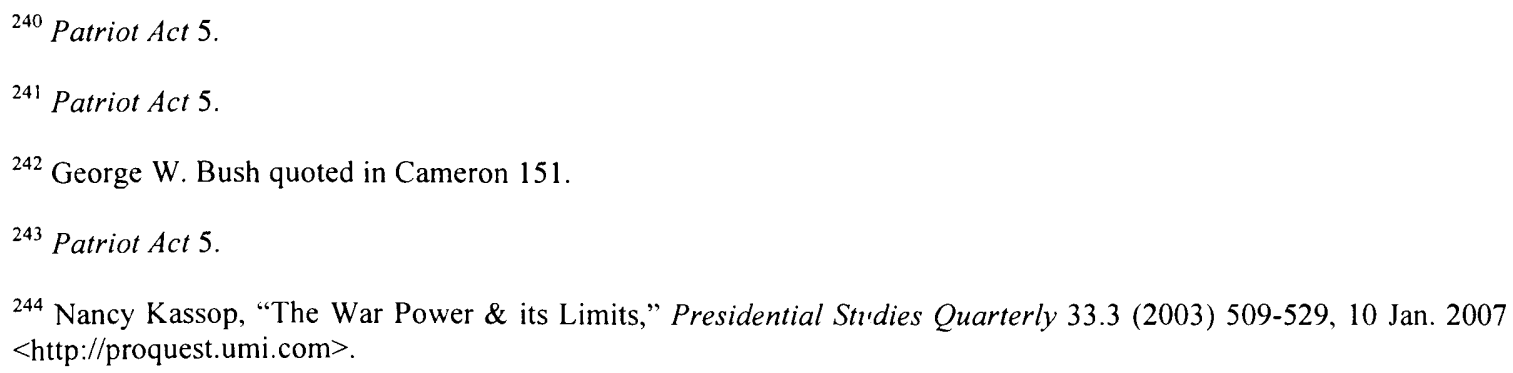


of signification, which has enabled a "network of laws and policies of expansive scope and uncertain duration" to be established. ${ }^{245}$ Security premised on an infrangible "threat" enables an Orwellian "war-is-peace" mentality to anchor and legitimate US power to define global security. US President George W. Bush reminds the US and the global polity that the US is engaged in "a different kind of war. It's a war that is not measured by the destruction of tanks, or ships, or aircraft, berause we're fighting a different kind of enemy."246 The "different kind of enemy," that is, terror, has significant implications for how security will be defined and operationalized, for example, war can be waged under the aegis of traditional, power-politics state-to-state combat and/or expansive moral and legal violations of universal norms. "The Bush administration has pursued both in its efforts to uproot and eradicate 'terrorism,' and has fused the two into what might be termed the 'militarization of law enforcement,' with the 'war' on terrorism furnishing the predicate" for unhampered action at the domestic as well as the international level. ${ }^{247}$ Militarization of law enforcement is part of a public-safety security rubric in which the US seeks to procure a zero-risk security environment wholly amenable to US interests.

The PA establishes a system of security that engenders unconstrained boundaries.

Take, for instance, section 203(a)(lc), which holds that (foreign) intelligence is:

(I) Information, whether or not concerning a US person, that relates to the ability of the US to protect against-(aa.) actual or potential attack or grave hostile acts of a foreign power or an agent of a foreign power; (bb.) sabotage or international terrorism by a foreign power or an agent of a foreign power; or

\footnotetext{
${ }^{245}$ Kassop, "War."

${ }^{246}$ George W. Bush, speech, Republican Governors Association 2002 quoted in Kassop, "War."

${ }^{247}$ Kassop, "War."
} 
(cc.) clandestine intelligence activities by an intelligence service or network of a foreign power or by an agent of foreign power; or (II) Information, whether or not concerning a US person, with respect to a foreign power or foreign territory that relates to(aa.) the national defense or security of the US; or (bb) the conduct of foreign affairs of the US. ${ }^{248}$

Such measures give rise to a security "discourse that systematically reifies a ... specific spatial ontology, a sharp delineation of here and there, a discourse that both expresses and constantly affirms the presence and absence of political life inside and outside the [unipolar] state as the only ground on which structural necessities can be understood and ... realms of freedom ... revealed." 249 PA security has the attribute of engaging in the "spatial capture" of any potential and actual threat. PA Section 802 establishes an expansive, protean definition of "domestic terrorism." Qualitative differences between foreign and domestic terrorism are blurred under the PA, encompassing activities that:

(A) involve acts dangerous to human life that are a violation of the criminal laws of the US or of any State; (B) appear to be intended (1) to intimidate or coerce a civilian population, or (2) to influence the policy of a government by mass destruction, assassination, or kidnapping, or (3) to effect the conduct of a government by mass destruction, assassination, or kidnapping. ${ }^{250}$

Also, Section 808 implies any "such acts that result in virtually any federal crime of violence" as being construed as threats to national security; "conceivably, these

\footnotetext{
${ }^{248}$ Patriot Act 8.

${ }^{249}$ R.B.J. Walker, Inside/Outside: International Relations as Political Theory (New York: Cambridge University Press, 1993) ix.

250 John W. Whitehead and Steven H. Aden, "Forfeiting 'Enduring Freedom' for 'Homeland Security': A Constitutional Analysis of the USA PATRIOT Act \& the Justice Department's Anti-Terrorism Initiatives," 51 Am. U. L. Rev. 1081, The American University Law Review (August 2002), 12 Jan. 2007 <http://web.lexis-nexis.com>.
} 
extensions of the definition of terrorism could bring within their sweep diverse domestic political groups, which have been accused of acts of intimidation or property damage."251 Security can be "characterized fundamentally by a lack of boundaries [with] no limits."252

Under PA security, global society becomes a product of and beholden to US ideology. As Fredric Jameson notes, this is significant because ideology manifests itself by ordering the totality of thought and action; ideology is "that grillwork of form, convention, and belief which orders our actions. ${ }^{253}$ Security assumes the validity of a dichotomous "inside/outside" equation of international actuality: it revolves around preventing the "transgression of borders between established forms of order and community inside and the realm of either danger (insecurity, war) or a more universalistically conceived humanity (peace) outside. ${ }^{, 254}$ Absolutist, militaristic security is, therefore, the mechanism that informs the primary modus operandi of US security, and the means to comprehend any threat (real or imagined) that confronts the US domestically as an international threat. The term "any" bestows vast degrees of freedom to the author defining terror. Any person within and without the jurisdiction of the US that engages in any act that, "if committed within the jurisdiction of the US, would constitute an offense under [the PA] shall be subject to the fines, penalties, imprisonment, and forfeiture.",255

\footnotetext{
${ }^{251}$ J. W. Whitehead, "Forfeiting."

${ }^{252}$ Hardt, Empire xiv.

${ }^{253}$ Fredric Jameson, The Prison-House of Language: A Critical Account of Structuralism and Russian Formalism (Princeton: Princeton University Press, 1974) 107.

${ }^{254}$ Walker 18.

${ }^{255}$ Patriot Act 58. Also, see T. J. Rodgers, "British, US Spying Draws Us Closer to Orwell's Big Brother," San Jose Mercury News, 29 Dec. 2005, 7 July 2007 <commondreams.org/views05/1229-35htm>.
} 
PA security delineates and interprets percept apparatuses and prescriptive statements, resulting in a self-referential system that possesses "sole un-reviewable discretion" of its methods and enforcement mechanisms. ${ }^{256}$ If the PA is construed as a specific act of political warfare, centers of resistance constitute "threats" that legitimate the US as vanguard of global peace, freedom, and justice. The PA lexicon of warfare, which posits a "war with no easily identifiable foe nor any agreed understanding of what would constitute decisive defeat of the enemy and termination of the threat," fuels a perpetual absolutist security discourse. ${ }^{257}$ The PA, as an instrument of "counterterrorism," collapses foreign and domestic policy into a unified and seamless whole on an absolute scale. US national security policy, at home and abroad, is the means by which the lines are blurred between foreign and domestic, US and global security.

It is interesting to note that PA security measures are part of a historical continuity of US hegemonic aspirations. Under the aegis of security, the US has historically utilized legal instruments to define the parameters of political reality. One can recall the Sedition Act of 1798, which made it a crime to criticize the policies/practices of the US, or the Espionage Act of 1917, which made it felonious to "willfully utter, print, write, or publish any disloyal, profane, scurrilous, or abusive language" pertaining to the US government. ${ }^{258}$ The US has consistently utilized law to legislate state-protective acts. The US Supreme Court's "clear and present danger" standard (which held that the US

\footnotetext{
${ }^{256}$ Patriot Act 63.

${ }^{257}$ Kassop, "War." Also, see David Cole and James Dempsey, Terrorism and the Constitution: Sacrificing Civil Liberties in the Name of National Security $2^{\text {nd }}$ ed. (New York: W. W. Norton, 2002).

${ }^{258}$ Nancy Chang, Silencing Political Dissent, forward Howard Zinn (New York: Seven Stories, 2002) 23. For full text of the US Alien and Sedition Act of 1798, see US Library of Congress, Primary Documents in American History: A Century of Lawmaking for a New Nation. U.S. Congressional Documents and Debates, 1774 - 1875. Updated May 31, 2006, 7 June $2007<$ http://www.loc.gov/rr/program/bib/ourdocs/Alien.html>.
} 
could legitimately suspend its self-imposed circumscriptions on the exercise of its power), for example, is exemplary of the state's capacity to privilege its security interests over all others. Any act can be "rationally" construed as constituting a "clear and present danger." The Smith Act of 1940 made it a crime to "knowingly or willfully advocate, abet, advise, or teach the duty, necessity, desirability, or propriety of overthrowing or destroying any government in the US by force or violence."259 The US's highest selfappointed juridical apparatus (the US Supreme Court) then articulated "the gravity of evil" standard to legitimize security measures controlling public speech acts of citizensubjects. A more recent campaign of unfettered security involved the FBI engaging in surreptitious police activity in the COINTELPRO program (1956-1971). The FBI, under color of law and in the interest of national security, engaged in spying and interference so as to "expose, disrupt, misdirect, discredit, or otherwise neutralize activities of individuals and organizations perceived by the government to pose a threat" to national security. ${ }^{260}$ Under the PA, US domestic imperatives embodied in COINTELPRO have been internationalized in legal instruments.

\footnotetext{
${ }^{259}$ Chang 24. Also see United States Code (USC), TITLE 18, PART I, CHAPTER 115, $\$ 2385$ Advocating Overthrow of Government, Cornell University Law School Legal Information Institute, 7 June 2007

$<$ http://www.law.cornell.edu/uscode/html/ uscode18/usc_sec_18_00002385--.-000-.html>.

${ }^{260}$ Chang 30-35. Regarding analyses of COINTELPRO see: Mike Cassidy and Will Miller, $A$ Short History of FBI COINTELPRO, 28 June $2007<\mathrm{http}: / /$ www.monitor.net/monitor/9905a/jbcointelpro.html>; U.S. Congress, House of Representatives Committee on Internal Security, Hearings on Domestic Intelligence Operations for Internal Security Purposes, $93^{\text {rd }}$ Cong., 2d sess, 1974; U.S. Congress, House of Representatives Select Committee on Intelligence, Hearings on Domestic Intelligence Programs, $94^{\text {th }}$ Cong., 1st sess, 1975; U.S. Congress, Senate Committee on Government Operations, Permanent Subcommittee on Investigations, Hearings on Riots. Civil and Criminal Disorders. 90th Cong., 1st sess. - 91st Cong., 2d sess, 1967-1970; U.S. Congress, Senate Select Committee to Study Governmental Operations with Respect to Intelligence Activities, Hearings: The National Security Agency and Fourth Amendment Rights, vol. 6. 94th Cong, 1st sess, 1975; U.S. Congress, Senate Select Committee to Study Governmental Operations with Respect to Intelligence Activities, Hearings: Federal Bureau of Investigation, vol. 6. 94th Cong., 1st sess, 1975; U.S. Congress, Senate Select Committee to Study Governmental Operations with Respect to Intelligence Activities, Final Report, Book II, Intelligence Activities and the Rights of Americans, 94th Cong., 2d sess, 1976; U.S. Congress, Senate Select Committee to Study Governmental Operations with Respect to Intelligence Activities, Final Report - Book III, Supplementary Detailed Staff Reports on Intelligence Activities and the Rights of Americans, 94th Cong., 2d sess, 1976.
} 
The above observations of the plasticity of security can be observed in the domestic/global financial dimensions of the PA as well. Under the PA, the US now requires the US Secretary of the Treasury to "cncourage further cooperation among financial institutions, their regulatory authorities, and law enforcement authorities, with the specific purpose of encouraging [such authorities] to share information regarding individuals, entities, and organizations." ${ }^{261}$ The PA has also amended the Bank Secrecy Act, noting that:

\begin{abstract}
Congress finds (A) adequate records maintained by insured depository institutions have a high degree of usefulness in criminal, tax, and regulatory investigations or proceedings, and that, given the threat posed to the security of the Nation ... such records may also have a high degree of usefulness in the conduct of intelligence or counterintelligence activities ... and (B) microfilm or other reproductions and other records made by insured depository institutions of checks, as well as records kept by such institutions, of the identity of persons maintaining or authorized to act with respect to accounts therein, have been of particular value as well. ${ }^{262}$
\end{abstract}

The PA works in tandem with other international institutions, such as the UN, to aggressively perpetuate US power and security interests; this has the effect of tincturing security with international political economy. The internationalization of US global economic and security interests is evident in the rapid passage of UN Security Council Resolution 1373 (28 September 2001), which complements the PA. US President George

\footnotetext{
${ }^{261}$ Patriot Act 30.

${ }^{262}$ Patriot Act 46. Also, see Larry Abramson, "The Patriot Act: Alleged Abuses of the Law," National Public Radio, 28 July 2005, 2 August $2007<w w w . n p r . o r g / t e m p l a t e s / s t o r y /$ story.php?storyld=4756403>; Nancy Chang, Silencing Political Dissent, forward Howard Zinn (New York: Seven Stories, 2002); Nancy Kassop, "The War Power \& its Limits," Presidential Studies Quarterly 33.3 (2003) 509-529, 10 Jan. 2007 <http://proquest.umi.com>.
} 
W. Bush emphatically stated, "Every UN member has a responsibility to crack down on terrorist financing. We must pass all necessary laws in our own countries to allow the confiscation of terrorist assets. We must apply those laws to every financial institution in every nation" (emphasis added). ${ }^{263}$ Money laundering "and the defects in financial transparency on which money launderers rely, are critical to the financing of global terrorism and the provision of funds for terrorist attacks, ${ }^{, 264}$ menaces "the safety of US citizens and undermines the integrity of US financial institutions and [the] global financial and trading systems upon which prosperity and growth depend."265

The PA broadly premises US security policy/interests as a global duty and imperative. A political economy of terror has assumed a global functionality, interpenetrating the various nation-states that comprise international order. To infiltrate every possible dimension of state security (economic, military, political, social, cultural) is how the US seeks to attain absolute security from terror. A comprehensive regime of truth, perpetuated by an $A S A$ discourse via the PA, postulates the US directive to "provide a clear national mandate for subjecting to special scrutiny those foreign jurisdictions, financial institutions operating outside of the US, and classes of international transactions or types of accounts that pose particular, identifiable opportunities for criminal abuse." 266 The US has ex-officio decreed itself adept to sequester any assets, foreign or domestic, used in the perpetuation of any type of crime against the US in any way that threatens US

\footnotetext{
${ }^{263}$ George W. Bush, speech, United Nations General Assembly, New York, NY, 2001, The George W. Bush Foreign Policy Reader: Presidential Speeches With Commentary, ed. John W. Dietrich (New York: M.E. Sharpe, 2005) 57.

${ }^{264}$ Patriot Act 22.

${ }^{265}$ Patriot Act 22.

${ }^{266}$ Patriot Act 23.
} 
security. Furthermore, any assets used by an individual or organization that is engaged in/planning any act of domestic or international terrorism (as defined by the US) will be forthwith appropriated by the US. ${ }^{267}$ Under an absolutist security framework, the US is the sole competent power to dictate and enforce standards that define terror. The significance of such pronouncements is that the federal definition of terrorism is so expansive that virtually any "reasonable" or "unreasonable" hostile act can be construed as in some way contributing to a terrorist threat: racketeering, cyber-terrorism, maritime affairs, nuclear and other hazardous materials, biological agents, aviation, railways, religion, shipping, the food industry, civil and political liberties, domestic dissent, consumer products, and utilities, amongst many things, have the potential to fuel a totalizing concept of security that permeates, penetrates, and transcends US national borders.

A unipolar, militarized, police-power notion of security trivializes all other state (as well as non-state) actors and interests in the international system. Global public safety and a zero-risk security environment reign supreme under the US $A S A$. Jose Alvarez contends that the PA constitutes an expression of hegemonic international law (hereinafter, HIL) on the world, and erodes the spirit and fabric of a pluralistic and diverse system of states. According to Alvarez, this occurs because law is divested of its ability to transcend the purely ideological and political aims of the hegemon.

HIL jettisons or severely undervalues the formal and de facto equality of states, replacing pacts between equals grounded in reciprocity, with patron-client relationships in which clients pledge loyalty to the hegemon in exchange for security or

\footnotetext{
${ }^{267}$ Patriot Act 88.
} 
economic sustenance. The hegemon promotes, by word and deed, new rules of law ... and disregards, when inconvenient ... international law, confident that its breach will be hailed as a new rule. ${ }^{268}$

In line with the domestic function of security, HIL depreciates cosmopolitan security and postulates US security injunctions as the appropriate basis for global security measures in place of legal principles and statutes. "Substantively, HIL is characterized by indeterminate rules-whose vagueness benefits primarily (if not solely) the hegemon."269 The PA, then, can be viewed as an institutionalized, hegemonic security percept-system, a legal asseveration that the US can and will intervene in the affairs of any state, with unbounded issue-linkage between security and terror enabling this to transpire "licitly." Threat is therefore construed as any attempt by enemies of global peace and freedom to dismantle the US-managed and defined international order. Law is a means by which US security $=$ global security transpires. For example, the PA grants the US president the power to adjudge if

a foreign country has taken or has committed to take actions that contribute to efforts of the US to respond to, deter, or prevent acts of ... terrorism, [and to authorize] the [Treasury] Secretary ... to instruct the US Executive Director of each international financial institution to use [their] voice and vote ... to support any loan or other utilization of the funds of the respective institutions for such country, or any public or private entity within such country. ${ }^{270}$

\footnotetext{
${ }^{268}$ Alvarez 1.

${ }^{269}$ Alvarez 1.

${ }^{270}$ Patriot Act 48.
} 
In effect, the PA can be construed as a manifesto of US power to unilaterally define and implement global security. The UN Security Council's Counter-Terrorism Committee (CTC) is exemplary of an articulation of the US "public right" to articulate and implement global security. The CTC's

legally binding orders regarding counter-terrorism-imposing financial sanctions on designated individuals and organizations and a welter of other obligations on states - are that rare phenomenon in international law: legally binding regulation, backed by the possibility of real enforcement action, imposed on all states by a global international organ engaged in a continuous legislative enterprise by virtue of delegated power and subject to no geographic or temporal limitation. ${ }^{271}$

The continual dislocation, reprocessing, and modification of categorical elements of the initial "basic reality" of the international states-system framework involves processes that substitute simulacra in place of those "basic realities" that initially informed international order (IO). For instance, PA securitization measures have infiltrated and enervated cardinal IO constructs such as sovereignty and law, rendering them weak, utilizing them as a means of furthering the unipolar security enterprise. The CTC is led by experts

not evidently chosen on the basis of representing the diverse legal cultures of the world or their qualifications in international law. The CTC model for counter-terrorism legislation has been guided by the US. The CTC is aimed at globally exporting US counter-terrorism legislation, particularly the US PATRIOT Act. The CTC reflects the priorities of the hegemon and elevates security over other concerns. ${ }^{272}$

\footnotetext{
${ }^{271}$ Alvarez 3.

${ }^{272}$ Alvarez 3.
} 
The US $A S A$ has, therefore, become the general matrix for "relations of power and techniques of domination ... a form of rule aimed not only at controlling the [domestic] but producing and reproducing all aspects of [international] life."273

All juridical acts involve the establishment of matrices of subject/object signification. To have a subject utilize controlled significations, as if they existed within the nous of the subject itself, is a hallmark of the $A S A$. "The role of [hegemonic] political power is perpetually to use a sort of silent war to re-inscribe" the relationship of unipolar security, force, inducement, and obedience, "and to re-inscribe it in institutions, economic inequalities, language, and even the bodies of individuals." ${ }^{274}$ State actors thus find themselves inscribed within a unipolar system of absolute security, the targets of global offensives rooted in a "domination-repression" matrix of struggle/submission via force and inducement. ${ }^{275}$ Security, then, assumes a biaxial manifestation of truth, of objective control over global security conceptualization.

\section{Waging War to Wage Peace}

"Power constantly asks questions and questions us; it constantly investigates and records; it institutionalizes the search for truth." ${ }^{276}$ The PA must therefore be viewed within a complex of techniques, media, and technologies that have the effect of establishing an authoritative structuration of systemic international order. If viewed in

\footnotetext{
${ }^{273}$ Michael Hardt and Antonio Negri, Multitude: War \& Democracy in the Age of Empire (New York: Penguin, 2004) 13.

${ }^{274}$ Foucault, Society 16.

${ }^{275}$ Foucault, Society 17.

${ }^{276}$ Foucault, Society 25.
} 
such a manner, the PA, as an act of political warfare, constitutes an act of political invasion. "Invasion, with its forms, motifs, and effects, becomes a ... problem to the extent that it ... defines the very principles of [international] public right."277 The PA, therefore, reflects and constitutes an economy of power, whose currency translates into global panoptic surveillance, transcription, inscription, detention, and legal recrimination of the highest order/degree. "A right of sovereignty and a mechanics" of securitization work in tandem to legitimate an expansive, discursive edifice of global order. ${ }^{278}$ The PA, in addition to being a juridical creation, is also a normative, moralistic, ideological apparatus of knowledge that presents the US $A S A$ as an objective, systemic compos mentis. Politics and legality are, in light of the PA, a continuation of war. Beneath the concept and practice of law, the universal, objective means of stabilizing the human condition, "war continues to rage in all the mechanisms of power, even in the most regular. War is the motor behind institutions and order ... [and] we have to interpret the war that is going on beneath peace; peace itself is coded war. ${ }^{279}$ All subjects reside on the "battlefront" of security and securitization measures; there is no detachment, no placid repose or independent space that emerges from frameworks of security.

Although the PA is held out as being grounded in a security = liberty equation, this equation metamorphoses into a circuitous security $=$ liberty $=$ security, ad infinitum equation; rather than each term possessing an independent status or devolving from the other, the PA obliterates any demarcation, privileging security sui generis as the singular

\footnotetext{
${ }^{277}$ Foucault, Society 124.

${ }^{278}$ Foucault, Society 36.

${ }^{279}$ Foucault, Society 51.
} 
means to procure universal freedom, liberty, and justice. ${ }^{280}$ Under the PA, liberty loses $^{2}$ its independent efficacy, and is rendered a subset of security. Liberty assumes the status of a simulacrum, utilized by the unipolar state to promote its security agenda. The preventive and preemptive dimension of the PA, based on the singular and ubiquitous nature of terror, leaves "open-ended any determination of the point at which hostilities have ended."281 The US categorically asserts that:

the war on terror will not be won on the defensive. We must take the battle to the enemy, disrupt his plans, and confront the worst threats before they emerge ... And our security will require all Americans ... to be ready for preemptive action when necessary to defend our liberty and defend our lives ... We must be prepared to stop rogue states and their terrorist clients before they are able to threaten ... the US. ${ }^{282}$

Furthermore, it is contended that "the inability to deter a potential attacker, the immediacy of today's threats, and the magnitude of potential harm that could be caused by our adversaries' choice of weapons, do not permit a reactive posture. We cannot let our enemies strike first."283 The US $A S A$ provides an immense amount of discretion to define and perpetuate unilateral war and global security.

By perpetuating a barrage of securitization efforts premised on a peace-inducing war-mentality against an intangible adversary, the US ASA is able to assert the primacy

\footnotetext{
280 Thomas F. Powers, "Can We Be Secure \& Free?" Public Interest 151 (Spring 2003) 3-21, National Affairs Incorporated, Washington, D.C., 12 Feb. $2007<w w w . h t t p: / / p r o q u e s t . u m i . c o m>$.

${ }^{281}$ Kassop, "War."

${ }^{282}$ George W. Bush, speech, West Point Military Academy 2002 quoted in Kassop, "War.”

${ }^{283}$ US National Security Strategy 2002, cited in Kassop, "War.” Also, see "Congress Passes Anti-Terror Bill,” BBC News Online, 28 July 2007, 5 Aug. 2007 <news.bbc.com.uk/2/hi/Americas/6920198.stm>.
} 
of a US agenda, that is, preservation of the security of the US Homeland at any and all costs via law and militarized law enforcement. ${ }^{284}$ Preserving the Homeland embodies a "virtual abandonment of ... barriers between foreign intelligence and domestic law enforcement." 285 The PA's reach projects outward as well as inward; homogenization and coordination of security apparatuses have been effectuated, resulting in a more undifferentiated system of state surveillance and control. Previous distinctions, which had had the effect of constraining intelligence gathering, data sharing, and un-moderated law enforcement conduct, have been dismantled or seriously weakened. Before the PA, the Foreign Intelligence Surveillance Act (hereinafter, FISA) served as a "firewall between foreign and domestic intelligence gathering." ${ }^{286}$ A clearer distinction existed between "investigative conduct in domestic criminal investigations and in foreign intelligence investigations. By creating this distinction, FISA served to protect the Fourth Amendment rights of US citizens in criminal investigations, requiring probable cause before a search warrant is issued and preserving freedom from unreasonable search and seizure." 287 The PA has diluted such protections; any and all activities directed against the US (foreign and domestic) are now presumed to be criminal in nature, subject to the jurisdiction of the US. The US is now less encumbered in its quest to bolster security via prevention of ubiquitous terror. Scrutiny standards for intrusive conduct permitted by the US, after passage of the PA, are now held at a much more permissive standard. "Instead

\footnotetext{
${ }^{284}$ Paul T. Jaeger, John Carlo Bertot, and Charles McClure, "The Impact of the USA PATRIOT Act on Collection \& Analysis of Personal Information Under the FISA," Government Information Quarterly 20.3 (2003) 295-314, 6 Jan. $2007<$ http://proquest.umi.com>.

${ }^{285}$ Jaeger, "Impact."

${ }^{286}$ Jaeger, "Impact."

${ }^{287}$ Jaeger, "Impact."
} 
of requiring that gathering information about foreign intelligence activities be the purpose of a FISA investigation, it now needs to be a significant purpose-only one of a number of purposes."288 This has the effect of dismantling distinctions that previously prevented the state from meta-expansive surveillance and trarsscription.

Before the Patriot Act, the records that law enforcement agencies could collect and analyze under FISA were limited to specific pieces of information, such as hotel registrations, car rentals, and storage unit rentals. Under the Patriot Act, investigators can collect and analyze a wide range of records that include 'any tangible thing (including books, records, papers, documents, and other items).' This difference is enormous, allowing for an investigation to tap into virtually any form of information. ${ }^{289}$

Preserving the Homeland has, therefore, resulted in a "militarization" of law enforcement, at home and abroad; this state of affairs, combined with a virtually unlimited space of definition regarding threat, safety, and "clear and present" dangers, has serious consequences for global security policy. The Bush Administration, for instance, has "crafted and imposed policies that put a premium on secrecy, and has left little doubt that it operates under the assumption that no tactic by the US in the war against terrorism, including torture and preemptive military action, is too excessive.",290 Such a policy is at odds with an open, democratic society that is the beacon of global peace and freedom, and a system of sovereign states. The PA has transformed law enforcement, producing a distinct modality of law-securitization, resulting in a pliable,

\footnotetext{
${ }^{288}$ Jaeger, "Impact."

289 Jaeger, "Impact."

${ }^{290}$ Kassop, "War."
} 
orderly, subservient political context that encourages and effectuates convergence of international society's well-being with the unipolar state's security mandates. Via the PA, the US as a unipolar state is systemically reified and re-inscribed into the domestic and international political discourse. Hence, the US president has been empowered to use "all necessary and appropriate force against those nations, organizations, or persons he determines planned, authorized, committed, or aided the terrorist attacks that occurred on September 11, 2001, or harbored such organizations or persons" (emphasis added) ${ }^{291}$

\section{Conclusion}

"The triumph of some means the submission of others.", juridical and political warfare, the US unipolar state has assumed the part of global systems-manager, planner, and guardian, concerned solely with the maximization of all that is universally "good" in the structure and conduct of international affairs. Acting in the name of universal ideals (Law, Justice, Morality), the US ASA has been clothed in the garb of an ineluctable, pragmatic, proper, organic "good," articulated in the name of all peace-loving peoples who desire nothing but harmony, stability, order, and most importantly freedom. The US combats unpropiticus appraisals of its security policy by restating critiques within its $A S A$ terms, effectively emptying critiques of any type of discerning, viable content. Former US Attorney General John Ashcroft has emphatically declared that the US polity requires nothing less than fealty to the following decree:

\footnotetext{
${ }^{291}$ US Congress, "Authorization for Use of Military Force (Enrolled Bill), S.J.Res.23, 107 ${ }^{\text {th }}$ Congress of the United States of America," 20 April $2008<$ http://news.findlaw.com/hdocs/docs/terrorism/sjres23.enr.html>.

${ }^{292}$ Foucault, Society 70.
} 
we need honest, reasoned debate; not fear-mongering ... To those who scare peace-loving people with phantoms of lost liberty, my message is this. Your tactics only aid terrorists-for they erode our national unity and diminish our resolve. They give ammunition to America's enemies, and pause to America's friends. They encourage people of good will to remain silent in the face of evil. ${ }^{293}$

Unity, resolve, trust, war, patriotism, obedience-all of these states of affairs are presented from a discrete unipolar security discourse manifested in US security policy. Hence, the need to examine the $A S A$ because "ideas, cultures, and histories cannot seriously be understood or studied without their force, or more precisely their configurations of power, also being studied."294 Under the $A S A$, the political and social ramifications of absolutist security policy are summarily dismissed, relegated to the margins, declared un-essential, unpatriotic, pernicious, or even deleterious. Hence, the US President can articulate the following retort to those who object to the PA, as well as to those who object to the exercise of US global power via a US domestic legal instrument:

Our way of life, our very freedom came under attack in a series of deliberate and deadly terrorist acts ... thousands of lives were suddenly ended by evil, despicable acts of terror ... A great people have been moved to defend a great nation ... America was targeted for attack because we're the brightest beacon for freedom and opportunity in the world. And no one will keep that light from shining. ${ }^{295}$

\footnotetext{
${ }^{293}$ John Ashcroft, US Attorney General's Office, quoted in Whitehead, "Forfeiting."

${ }^{294}$ Edward W. Said, "Orientalism," The Norton Anthology of Theory and Criticism, eds. Vincent B. Leitch, William E. Cain, Laurie A. Fink, Barbara E. Johnson, John McGowan, and Jeffery J. Williams (New York: W.W. Norton, 2001) 1994.

${ }^{295}$ George W. Bush quoted in Howard 621.
} 
In order to ensure that the joie de vivre that US "freedom" provides remains ever present, guiding international society onto a righteous path, the US has directed the following:

that the full resources of ... intelligence and law enforcement communities [be used] to find those responsible and bring them to [the US government's fair justice]. We will make no distinction between the terrorists who committed these acts and those who harbor them ... America and our friends and allies join with all those who want peace and security in the world, and we stand together to win the war against terrorism ... [Pray] for all whose sense of security and safety has been threatened ... We go forward to defend freedom and all that is good and just in the world. $^{296}$

In light of this, Jean Baudrillard asks, when considering the fact that a single global power monopolizes global security perception and conceptualization,

when no alternative form of thinking is allowed, what other way is there but a terroristic situational transfer? ... To a system whose very excess of power poses an insoluble challenge, [terror responds] with a definitive act which is also not susceptible of [symmetric] exchange. Terrorism is the act that restores an irreducible singularity to the heart of a [unipolar] system of generalized exchange. ${ }^{297}$

The doctrine of "extraordinary rendition" instituted by the US further exemplifies how the US $A S A$ has found expression on the world stage. In particular, the case of Khaled el-Masri is exemplary of the logic the under-girds the PA. El-Masri, a German citizen who alleged he was kidnapped by the CIA and tortured in a prison in Afghanistan,

\footnotetext{
${ }^{296}$ George W. Bush quoted in Howard 621-622.

${ }^{297}$ Baudrillard, Spirit 9.
} 
was denied the opportunity to seek redress in US courts on the 9 October 2007 when the US Supreme Court declined to consider his case. The Court's refusal to hear el-Masri's case let stand a ruling by the US Court of Appeals for the $4^{\text {th }}$ Circuit upheld a 2006 decision to dismiss

\begin{abstract}
Mr. Masri's lawsuit on the grounds that trying the case could expose state secrets $\ldots$ Nevertheless $\ldots$ the $4^{\text {th }}$ Circuit acknowledged the seriousness of the issues when it dismissed Mr. Masri's suit. 'We recognize the gravity of our conclusions that el-Masri must be denied a judicial forum for his complaint' $\ldots$ for it pits the judiciary's search for truth against the executive's duty to maintain the nation's security. ${ }^{298}$
\end{abstract}

US security is, therefore, paramount and trumps all other competing values. The case of Mr. el-Masri, "who is of Lebanese descent and was apparently the victim of mistaken identity, was the most extensively documented case of the CIA's controversial practice of 'extraordinary rendition,' in which terrorism suspects are abducted and sent for interrogation to other countries, including some in which torture is practiced."299 The US has invoked the state's secret privilege 39 times since $9 / 11$ to withhold information from the courts; "at the height of Cold-War tensions ... US presidents used the state secrets privilege six times from 1953 to 1976."300 An ultra-secretive modus operandi complements, reinforces, and augments the US ASA.

\footnotetext{
${ }^{298}$ David Stout, "Supreme Court Won't Hear Torture Appeal," New York Times Online, 9 Oct. 2007, 10 Oct. 2007 $<$ http://www. nytimes.com/2007/10/09/washington/09cnd-scotus.html?_r=1\&hp\&oref=slogin>.

${ }^{299}$ David Stout, "Supreme Court Won't Hear Torture Appeal," New York Times Online, 9 Oct. 2007, 10 Oct. 2007 $<$ http://www.nytimes.com/2007/10/09/washington/09cnd-scotus.html?_r=1\&hp\&oref=slogin>.

${ }^{300}$ Associated Press, "Court Nixes Man's Suit Claiming Torture by CIA; Justices Throw Out German's Challenge to Alleged Abduction by U.S. Agents," MSNBC News Online, 9 Oct. 2007, 10 Oct. $2007<$ http://www.msnbc.msn.com/id $/ 21205942 />$.
} 
International society's obedience and fidelity to the security mandates/dictates of the US is the overarching priority in global security measures. Fidelity to US power informs the rules of securitization which the US tacitly claims exemption from, and which the US rewards in a militarized, unipolar world. This is evident in US policy toward WMD proliferation in a post-Cold War, post-9/11 world. The issue of WMD proliferation and its role in perpetuating the US $A S A$ will be the focus of the following chapter. As is the case with criminalization and the PA, the US $A S A$ sets the purlieus as to what constitutes a legitimate and viable threat vis-à-vis WMD and global security, particularly by designating which states are permitted to justifiably and legitimately possess WMD technology. 
Proliferation in a post-Cold War, post-9/11 world has had significant consequences for the structure and management of global security policy. ${ }^{301}$ The introduction of nuclear weapons (hereinafter, NW) initially confounded and distorted conventional formulae of war and peace, such as limited warfare, armies, arms, munitions, strategy, and distinctions of non/combatants. NW, generally speaking, have been accommodated and rationalized, rendering them strategically functional within the discourse of global security. ${ }^{302}$ Since $9 / 11$, NW have assumed an important role in the justification of the US $A S A$, for example, North Korea's testing of a nuclear device and Iran's determination to acquire nuclear capability have had serious consequences on US and, by default, global security policy. Keeping NW within the purview of select states while concomitantly excluding those states the US designates enemies of global freedom, that is, rogue states, is considered a major component of the war on terror.

Theoretically, a nuclear power cannot logically engage a non-nuclear state in actual combat; indeed, there is no functional, complementary relationship between the two- total-death neutralizes the playing field. This also holds for engagement between nuclear powers-where the obliteration of all states will result from the mass use of nuclear weapons. Yet, the US has forcefully asserted its right to use NW against any

\footnotetext{
${ }^{301}$ See Michael Hamel-Green, Regional Initiatives on Nuclear and WMD-Free Zones: Cooperative Approaches to Arms Control and Non-Proliferation, forward Patricia Lewis (Geneva: United Nations Institute for Disarmament Research, 2005); James A. Russell, ed., Proliferation of Weapons of Mass Destruction in the Middle East: Directions and Policy Options in the New Century (New York: Palgrave, 2006).

${ }^{302}$ For examples see Peter Katona, John P. Sullivan, and Michael D. Intriligator, eds., Countering Terrorism and WMD: Creating a Global Counter-Terrorism Network (New York: Routledge, 2006); Stephen J. Cimbala, ed.. Deterrence and Nuclear Proliferation in the Twenty-First Century (Westport: Praeger, 2001).
} 
state deemed a threat, despite the "first pillar" of the NPT. ${ }^{303}$ The five nuclear states identified in the NPT, that is, the US (1968), UK (1968), USSR (1968, now Russia), France (1992), and China (1992) have stated that NW will not be used against states that do not possess NW except in response to a nuclear attack, or a conventional attack in alliance with a NW state. However, this policy has not been incorporated formally into the NPT, and practice has deviated from policy. The US has indicated that it may use NW in response to a non-conventional attack by rogue states, and that it had NW targeted at North Korea while it was non-nuclear from 1959-1991. ${ }^{304}$

The "strategy of preemption" is one of the more recent hegemonic acts of controlling NW. The Gulf War II is reflective of a US policy to "forestall or prevent ... hostile acts" of aggressors-with US disapproval of possession of nuclear technology being considered a "hostile act"-via preemptive military action. ${ }^{305}$ Klare argues that the US approach is reflective of an effort of trying to preserve a "world that no longer exists - a world in which WMD remain the exclusive prerogative of the [US and its allies.]"306 Initially, the USSR, by assuming the role of an ominous and mortal enemy,

\footnotetext{
${ }^{303}$ See "THIRD SESSION OF THE PREPARATORY COMMITTEE FOR THE 2005 REVIEW CONFERENCE OF THE PARTIES TO THE TREATY ON THE NON-PROLIFERATION OF NUCLEAR WEAPONS," Opening Statement, Chairman of the Third Session, Ambassador Sudjadnan Parnohadiningrat, 26 April 2004, United Nations, New York, NY, 16 July $2007<$ http://www.indonesiamission-y.org/i ssuebaru/Events/opening_npt.htm>; Alexander T. J. Lennon, ed., Contemporary Nuclear Debates: Missile Defenses, Arms Control, and Arms Races in the Twenty-First Century (Cambridge: Massachusetts Institute of Technology, 2002) 3-11; "NPT Documents, Facts, and Figures," International Atomic Energy Agency, 5 March $2007<\mathrm{http}: / /$ www.iaea.or g/Publications/Documents/Treat ies/npt.html>; Lawrence Freedman, The Evolution of Nuclear Strategy $3^{\text {rd }}$ ed. (New York: Palgrave, 2003) xiii.

304 "Analysis on Military, Security, Arms Control, and Non-proliferation Issues," Berlin Information Center (BITS) for Transatlantic Security, 4 March $2007<\mathrm{http} / /$ www.bits.de/index.html>.

${ }^{305}$ Freedman 453.

${ }^{306}$ Klare, "Ambivalent" 203. See Wendy Frieman, China, International Arms Control and Non-Proliferation (New York: Routledge-Curzon, 2004); Evan S. Medeiros, Chasing the Dragon: Assessing China's System of Export Controls for WMD-Related Goods and Technologies (Santa Monica: RAND Corp., 2005); Derek D. Smith, Deterring America: Rogue States and the Proliferation of Weapons of Mass Destruction (Cambridge: Cambridge University Press, 2006).
} 
provided fodder for channeling and giving shape to NW strategy. ${ }^{307}$ The loss of the bipolar ballast and the advent of ubiquitous terror after $9 / 11$ have redirected US efforts regarding containment and control of NW via preventing "undesirables" (rogue states and their "terrorist clients") from attaining nuclear technologies. ${ }^{308}$

The Post-9/11 Nuclear Threat

According to the US, when "it comes to nuclear weapons, the world has changed faster than US policy. The emerging security threats to the US, its friends and allies and even Russia now come from rogue states, terrorist groups and other adversaries seeking weapons of mass destruction and the means to deliver them. Threats also come from insecure nuclear stockpiles and the proliferation of dangerous technologies."309 US security in a post-911 world indicates a sharp break from the Cold War rubric, even though US imperial aspirations remain a salient and constant theme of its security policy. It "is time to leave the Cold War behind and defend against new threats of the $21^{\text {st }}$ century." 310 Curbing the proliferation of NW and other WMD in a post-Cold War, post9/11 world involves an approach to global security that retains the lexis of a states-system paradigm while basing action on unipolar security mandates. This is part of a general security strategy implemented after $9 / 11$, which has provided the US with a basis for justifiably pursuing an $A S A$. It is by the "simulation of a conventional, restricted

\footnotetext{
${ }^{307}$ Lawrence Freedman, The Evolution of Nuclear Strategy, $3^{\text {rd }}$ ed. (New York: Palgrave, 2003) 47.

${ }^{308}$ Freedman 130.

${ }^{309}$ George W. Bush, speech, The National Press Club, Washington, D.C., 23 May 2000, The George W. Bush Foreign Policy Reader: Presidential Speeches With Commentary, ed. John W. Dietrich (New York: M.E. Sharpe, 2005$) 25$.

${ }^{310}$ George W. Bush, speech, The National Press Club, Washington, D.C., 23 May 2000, The George W. Bush Foreign Policy Reader: Presidential Speeches With Commentary, ed. John W. Dietrich (New York: M.E. Sharpe, 2005$) 25$.
} 
perceptive field, where the premises and consequences of any act or event are calculable, that a political credibility can be maintained ... But if the entire cycle of any act or event is envisaged in a system where linear continuity and dialectical polarity no longer exist, in a field unhinged by simulation, then all determination evaporates."311

According to the US National Strategy to Combat Weapons of Mass Destruction (2002), US policy regarding WMD, US national security, and global security involves the following:

the US can no longer be sure that its enemies will lack WMD; the US must focus on defense of its territory through NMD and enhanced homeland security; the US should make plans to manage the consequences of attacks at home and abroad; and the US should continue nonproliferation programs and a proactive counter-proliferation strategy. ${ }^{312}$

Proactive US security policy includes unilateral decision-making, legislation, military incursions/ campaigns, and dissemination of US political, moral, and economic prerogatives as the basis for global peace and freedom. Preemptive and preventive US military strikes provide new ground rules for the implementation of a blanket security policy in order to "forestall or prevent ... hostile acts by our adversaries." US has announced its unqualified right to act unilaterally, to confiscate, interrogate, and target suspected states and individuals (foreign and domestic) without any or little accountability to the US polity or world community via global extraordinary rendition,

\footnotetext{
311 Jean Baudrillard, Simulations, trans. Paul Foss, Paul Patton and Philip Beitchman (New York: Semiotext, I983) 31.

${ }^{312}$ Dietrich 118 .

${ }^{313}$ George W. Bush, The National Security Strategy of the US, 12 July $2007<w w w . w h i t e h o u s e . g o v / n s c / n s s a l l . h t m l>$.
} 
being held as an enemy combatant, and/or interdiction of exported weapons and materials. In May of 2003, US President George W. Bush announced a new Proliferation Security Initiative (hereinafter, PSI), which exemplifies how the 9/11 warresponse has invested security with a capacity to encompass and develop a very broad range of security measures:

Some challenges of terrorism [such as NW/WMD proliferation] cannot be met with law enforcement alone. They must be met with direct military action ... The greatest threat to world peace is the spread of nuclear, chemical and biological weapons. And we must work together to stop proliferation ... When [WMD] or their components are in transit, we nuust have the means and authority to seize them. So today I announce a new effort to fight proliferation called the Proliferation Security Initiative [(PSI)]. The US and a number of our close allies ... have begun working on new agreements to search planes and ships carrying suspect cargo and to seize illegal weapons or missile technologies ... [and to] extend this partnership as broadly as possible to keep the world's most destructive weapons away from or shores and out of the hands of our common enemies. ${ }^{314}$

The US and its "allies," however, are not subject to any search and seizure, given that such practices would infringe upon the sovereignty of the US and it allies. This consequence of adhering to the PSI, that is, infringement on the integrity and sovereignty of nation-states, is only directed toward undesirable states that defy US mandates.

The offensive, absolute security embodied in the US ASA authorizes the US to ignore the rules it sets for others in the global order. The spectacle of $9 / 11$ has provided

\footnotetext{
${ }^{314}$ George W. Bush, speech, Warsaw Royal Castle, Krakow, Poland, 31 May 2003, The George W. Bush Foreign Policy Reader: Presidential Speeches With Commentary ed. John W. Dietrich (New York: M.E. Sharpe, 2005) 207. Also, see Mark J. Valencia, The Proliferation Security Initiative: Making Waves in Asia (New York: Routledge, 2006) 25-56; George Bunn and Christopher F. Chyba, eds., U.S. Nuclear Weapons Policy: Confronting Today's Threats, forward William J. Perry (Harrisonburg: R.R. Donnelley, 2006).
} 
the US with an empirical as well as moral and ethical basis for claiming exemption from the rules it demands all other states be bound by to combat terror. The use of tactical nuclear weapons in taking preemptive action in waging war against terror, for instance, has been presented as feasible in the Nuclear Posture Review 2002 (hereinafter NPR). The NPR points out the

value of missile defense and use of tactical nuclear weapons in coping with the new security environment of global terrorism and proliferation ... [and] suggest[s] adoption of a triad of offensive strike systems (both nuclear and non-nuclear), defenses (both active and passive), and a revitalized infrastructure. Central to this new strategic concept [is] offensive deterrence, namely preemption, and tactical use of nuclear weapons Terrorists or rogue states armed with [WMD] will likely test America's security commitments to its allies and friends. In response ... A broader array of capability is needed to dissuade states from undertaking political, military, or technical courses of action that would threaten US and allied security. US forces must pose a credible deterrent to potential adversaries who have access to modern military technology, including [WMD] ... US nuclear forces will continue to provide assurance to security partners ... This assurance can serve to reduce the incentives for friendly countries to acquire nuclear weapons of their own to deter such threats and circumstances. Nuclear capabilities also assure the ... that the US will not be subject to coercion based on a false perception of US weakness. ${ }^{315}$

Since 9/11, US global supremacy has sought to implement an $A S A$ that establishes the "facts" of global order and international society. Yet, under a unipolar framework, "facts all contribute only to setting the problem, not to its solution ... doubt can exist only where a question exists, a question only where an answer exists, and an answer only

\footnotetext{
${ }^{315}$ Chung-in Moon and Jong-Yun Bae, "The Bush Doctrine and the North Korean Nuclear Crisis," Confronting the Bush Doctrine: Critical Views From the Asia-Pacific, eds., Mel Gurtov and Peter Van Ness (London: RoutledgeCurzon, 2005) 51; US Department of Defense, Nuclear Posture Review Report, Submitted to Congress, 3I December 2001, Released 8 January 2002, 16 May $2007<\mathrm{http}: / / \mathrm{www}$.globalsecurity.org/wmd/library/policy/dod/npr.htm>.
} 
where something can be said." ${ }^{316}$ As with the war on terror, US policy regarding proliferation clearly identifies the "facts" of good and bad, the right and the wrong, the peace-lovers and the warmongers, US allies and enemies. The use of nuclear technology by select undesirable states for any purpose, peaceful or otherwise, such as Iran and North Korea, has been construed as utterly incompatible with the "facts" that inform US security interests. Previous frameworks that sought a more balanced solution to the issue of WMD and proliferation have been "re-defined." The NPT in particular has been reconceptualized. Rather than eventual global de-nuclearization of the world, the US has divided the world into acceptable (the US and its allies) and unacceptable (rogue states) nuclear actors.

North Korea and Iran, amongst other (rogue) states, are viewed as unacceptable nuclear actors. The US unilaterally declared, for instance, that the "international community" would "not tolerate construction of a nuclear weapon [by Iran]. Iran would be dangerous if it had a nuclear weapon. ${ }^{, 317}$ Libya, on the other hand, has been held out as an example of how an absolutist US policy can successfully force states to conform to "proper" rules of global society. Libya's declaration that it sought to de-nuclearize and renounce WMD programs, even though some observers pointed out that Libya had simply taken the obvious final step in its plans to join the (US-managed) society of states, was touted as a major victory by the US. It is certainly the case however, that the US ASA, backed by profound military power, has been effective in shaping the world in the

\footnotetext{
${ }^{316}$ Wittgenstein, Tractatus 88.

${ }^{317}$ George W. Bush quoted in David E. Sanger, "Bush Warns Iran on Building Nuclear Arms," New York Times, 19 June 2003.
} 
image of the US. For instance, eventually "over sixty countries, including a hesitant Russia, joined PSI[, and] the UN Security Council adopted Resolution 1540, which called on [all] states to refrain from aiding efforts by non-state actors to acquire WMD and take cooperative action to prevent illegal trafficking in WMD materials."

Terror and rogue states are, therefore, the "new" organizing principles of the post9/11 ASA. When the Cold War ended, the Director of the Institute for US and Canadian Studies (ISKRAN) of the Russian Academy of Science in Moscow, Georgi Arbatov, put forth the following question to the US: "now that you have lost your enemy, what will you do? The end of the Cold War [has] deprived the US not only of an enemy but also its core organizing principles on which it had based its foreign policy for four decades." As Charles Kegley and Eugene Wittkopf note, "fear of alien ideas-once communism, now Islamic fundamentalism [and terror] permeates official thinking. The perceived need to combat threatening forces, once the Soviet Union, now Iran [and other rogue states] remains pervasive. And a preference for military intervention to achieve policy objectives continues." 320 The explicit as well as subtle ties that bind all nations' security with US security, and that bind rogue states with US notions of terror, are salient and powerful factors in the articulation of post-9/11 security.

To maintain a semblance of a states system, the concept of rogue states has been utilized in order to establish "clear" enemies of peace and freedom.

\footnotetext{
${ }^{318}$ John W. Dietrich, ed., The George W. Bush Foreign Policy Reader: Presidential Speeches With Commentary (New York: M.E. Sharpe, 2005) 120.

${ }^{319}$ Georgi Arbatov quoted in Cameron 181.

${ }^{320}$ C.W. Kegley and E. R. Wittkopf, American Foreign Policy: Pattern \& Process (New York: St. Martin's Press, 1996) 7 .
} 
Rogue states are clearly the most likely sources of chemical and biological and nuclear weapons for terrorists. Every nation now knows that we cannot accept-and we will not accept-states that harbor, finance, train, or equip the agents of terror. Those nations that violate this principle will be regarded as hostile regimes. They have been warned, they are being watched, and they will be held to account. ${ }^{321}$

US President George W. Bush has forcefully and unequivocally decreed that, "for states that support terror, it's not enough that the consequences be costly-they must be devastating. The more credible this realty, the more likely that regimes will change their behavior-making it less likely that America and our friends will need to use overwhelming force against them." 322 To militarize the US polity, to create a sociopolitical context where threat is limitless, security policy moves from defined topical matters/categories to a constant state of fear and alert that justifies a militarized security policy wherein everything is fair game for securitization, that is, suppression, surveillance, preemption, militarization, criminalization, and prevention become universal values, norms, and practices to ensure global peace and freedom. The post-9/11 US ASA is grounded in a militaristic mentality. Militarized security, a security-as-war modality, enables the US to "justifiably" issue sweeping condemnations and unilateral, militarized responses to apperceived threats. It also enables the US to legitimately ignore any role the US may play in bringing about the circumstances fomenting warfare, while concomitantly making the US the sole competent power to deal with global threats.

\footnotetext{
${ }^{321}$ George W. Bush, speech, The Citadel, Charleston, South Carolina, 11 Dec. 2001, The George W. Bush Foreign Policy Reader: Presidential Speeches With Commentary, ed. John W. Dietrich (New York: M.E. Sharpe, 2005$) 127$.

${ }^{322}$ George W. Bush, speech, The Citadel, Charleston, South Carolina, 11 December 2001, The George W. Bush Foreign Policy Reader: Presidential Speeches With Commentary, ed. John W. Dietrich (New York: M.E. Sharpe. 2005) 129.
} 
The modality of war-is-peace, war-is-freedom, war-is-righteous-one that excludes any possibility for US responsibility/complicity in bringing about violence, conflict, and acrimony-provides fodder for absolutist rhetoric, policy, action, and condemnation of rogue states for doing what states do, such as seek offensive and defensive capabilities against their enemies.

Every state that actively sponsors terror is known to be seeking $[\mathrm{NW}]$ and the missiles to deliver them ... Their hope is to blackmail the US into abandoning our war on terror, and forsaking our friends and allies and security commitments around the world ... America will never be blackmailed, and we will never forsake our commitment to liberty ... If America wavers, the world will lose heart. If America leads, the world will show its courage. America will never waver. America will lead the world to peace. Our cause is necessary. Our cause is just. And no matter how long it takes, we will defeat the enemies of freedom. ${ }^{323}$

The "just" cause legitimates the US categorically rationalizing and upholding its "right" to use force indiscriminately to promote peace. ${ }^{324}$ In actuality, this absolutist, militaristic modality-despite a perpetual and monotonous rhetoric of peace-becomes an end in and of itself. The US ASA "leads, by necessity, to preventive war. The general insecurity that goes hand and hand with this results in the sacrifice" of ordering concepts embodied in a society/system of states. ${ }^{325}$ The US has unilaterally outlined seven points

\footnotetext{
${ }^{323}$ George W. Bush, speech, The Citadel, Charleston, South Carolina, 11 Dec. 2001, The George W. Bush Foreign Policy Reader: Presidential Speeches With Commentary, ed. John W. Dietrich (New York: M.E. Sharpe, 2005) 12930 .

${ }^{324}$ George W. Bush, speech, The National Defense University, Washington, D.C., 1 May 2001, The George W. Bush Foreign Policy Reader: Presidential Speeches With Commentary, ed. John W. Dietrich (New York: M.E. Sharpe, 2005) 173-75.

${ }^{325}$ Einstein 146.
} 
that now form the basis of global security policy vis-à-vis NW, attempting to reshape various treaties such as the ABM Treaty of 1972 and the NPT. In short, "no treaty that prevents [the US] from addressing today's threats, that prohibits [the US] from pursuing promising technology [such as NMD] to defend ourselves, our friends and our allies is in our interests or in the interests of world peace. ${ }^{326}$ There must be no hindrance-legal, diplomatic, military, technological, moral, political - to unipolar management of world affairs via global security policy, since "the greatest threats... [come] from terrorists who strike without warning, or rogue states who seek weapons of mass destruction." ${ }^{\text {327 }}$ The US has outlined the following seven components for dealing with proliferation:

1., expand the PSI; 2., criminalize proliferation; 3., contain WMD; 4., close 'loophole' in the NPT that allows non-nuclear states access to nuclear technology for peaceful purposes; 5 ., expand IAEA surveillance by implementing the Additional Protocol, which requires states to publicly declare if they are engaged in a broad variety of nuclear activities; 6 ., create IAEA special committee to focus intensively on verification of nuclear activities; and 7., no state being investigated for violations can serve on the IAEA Board of Governors or special committee. ${ }^{328}$

The seven-point agenda creates an intrinsically correct US modality of international relations/society. ${ }^{329}$

\footnotetext{
${ }^{326}$ George W. Bush, speech, Whitehall Palace, London, England, 19 Nov. 2003, The George W. Bush Foreign Policy Reader: Presidential Speeches With Commentary, ed. John W. Dietrich (New York: M.E. Sharpe, 2005) 134.

${ }^{327}$ George W. Bush, speech, The White House, Washington, DC, 13 Dec. 2001, The George W. Bush Foreign Policy Reader: Presidential Speeches With Commentary, ed. John W. Dietrich (New York: M.E. Sharpe, 2005) 136.

${ }^{328}$ George W. Bush, speech, The National Defense University, Washington, D.C., 11 Feb. 2004, The George W. Bush Foreign Policy Reader: Presidential Speeches With Commentary ed. John W. Dietrich (New York: M.E. Sharpe, 2005) 138-142.

${ }^{329}$ Lyotard, Postmodern 35.
} 
The politics of proliferation and militarization stem in part from the worldview, the politico-ideological perspective employed when adjudging security vis-⿳亠丷⿵冂-vis an ideal state of affairs. In the case of US and its view of global security, 9/11 provides the reference point for such a worldview. A perceptual/conceptual framework, in conjunction with "naked power," informs and shapes eventuation. This is significant because "our idea of what belongs to the realm of reality is given for us in the concepts which we use. ${ }^{, 330}$ The rogue state concept is part of a larger program of articulating and implementing an objective US system of security. In a post-9/11 world, a US unilateral, militaristic posture presents and constitutes a perpetual and ever-present threat that actually fuels and possibly legitimizes militarization by rogue states, sustaining fervent resistance to US power.

Every political configuration of order augments its power by manufacturing knowledge to establish a regime(s) of truth: that is, discursive as well as material "mechanisms and instances which enable a subject to distinguish true/false statements; the means by which each is sanctioned; the techniques and procedures accorded value in the acquisition of truth; the status of those who are charged with saying what counts as true."331 Truth, in its purest sense, is actually repressive in that it delimits permissible thought and possibility via exclusion. Order appropriates truth so as to accord itself the privilege of inclusion and exclusion, of what is or is not (can or cannot be) the case. It is "truth that makes the laws, that produces the ['true'] discourse which, at least partially,

\footnotetext{
${ }^{330}$ Hollis 83 .

${ }^{331}$ Michel Foucault, Power/Knowledge: Selected Interviews and Other Writings, 1972-1977, ed. and trans. Colin Gordon (New York: Pantheon, 1980) 131.
} 
decides, transmits itself, extends upon the effects of power. In the end, we are judged, condemned, classified, determined in our undertakings, destined to a certain mode of living or dying, as a function of the true discourses which are the bearer of the specific effects of power." 332

In light of US power, rogue states reason that they have little choice but to aggressively resist and/or counterbalance US power-especially military power-with proportional power to exist. Although bandwagoning, balancing, and the like provide alternate options, viable military power is an indispensable and fundamental component of state power in an anarchic, self-help world. From a rogue state perspective, the US invasion/occupation of Iraq and Afghanistan are examples of what happens to a state that is unable to effectively counter or deter US power. In the case of North Korea, "the war in Iraq had led the leaders in Pyongyang to draw three conclusions: a nonaggression agreement [(without sufficient military power to back up the DPRK)] with the US was pointless, no inspection regime would ever be good enough for Washington, and only a nuclear weapon would deter a US [military] intervention."333 US policy based on hardline militarism, transcendental morality, and unilateral prerogatives did not avert but rather seriously agitated an already volatile situation on the peninsula. Indeed, North Korea's eventual detonation of a nuclear weapon can be traced, in part, to a protracted history of US aggression. The belligerent posture regarding North Korea's nuclear disarmament in 2003 was, according to the DPRK:

\footnotetext{
${ }^{332}$ Foucault, Power/Knowledge 94.

${ }^{333}$ John Feffer, North Korea/South Korea: US Policy at a Time of Crisis (New York: Seven Stories, 2003) 12; "Statement of Foreign Ministry Spokesman Blasts UNSC's Discussion of Korean Nuclear Issue," Korean Central News Agency, Pyongyang, Democratic People's Republic of Korea, 7 April 2003, 14 August $2007<$ http://www.kcna.c o.jp/index-e.htm>; Doug Struck, "Citing Iraq, North Korea Signals Hard Line on Weapons Issue," Washington Post, 31 March 2003.
} 
precisely a prelude to war... The US intends to force the DPRK to disarm itself. The Iraqi war shows that to allow disarming through inspection does not help avert a war but rather sparks it. Neither international public opinion nor the UN Charter could prevent the US from mounting an attack on Iraq. This suggests that even the signing of a non-aggression treaty with the US would not help avert a war. Only the physical deterrent force, tremendous military deterrent force powerful enough to decisively beat back an attack supported by any ultra-modern weapons, can avert a war and protect the security of the country and the nation. This is a lesson drawn from the Iraqi war. ${ }^{334}$

In general, rogue states view militarization as a viable and necessary option, for example, maintaining and augmenting conventional military resources as well as efforts to develop offensive nuclear capacity, to persevere in light of US "aggression." Historically as well as presently, unsolicited US interference in the affairs of rogue states, for example, US military support of the Shah's regime in Iran, or attempts at outright military incursion/invasion, for example, Cuba's repulsion of the Bay of Pigs invasion force in 1962, makes militarization a priority-one that serves the defensive, ideological, symbolic, cultural, and political needs of regimes in power. The US has framed postCold War proliferation in absolutist moral terms: the US and its allies have an unconditional right to nuclear technologies, and those deemed enemies of global peace and freedom by the US are forbidden to develop/acquire nuclear technologies for any reason or purpose. During the Cold War, the US was selective as to which actors were permitted to have access to nuclear technologies; in a post-Cold War system, there is no viable counter-power to ballast or contain US security objectives. The rogue state

\footnotetext{
334 "Statement of Foreign Ministry Spokesman Blasts UNSC's Discussion of Korean Nuclear Issue," Korean Central News Agency, Pyongyang, Democratic People's Republic of Korea, 7 April 2003, 14 August 2007

$<$ http://www.kcna.co.jp/index-e.htm>.
} 
concept is as subjective, selective, and morally based as the US campaign against the USSR during the Cold War. ${ }^{335}$ The selective and inconsistent policy of US proliferation policy (both past and present) has contributed to the desirability of acquiring NW technologies by rogue states.

\section{North Korea \& WMD}

In a post-9/11 world rogue states, especially North Korea, have turned inward to resist and effectively combat the hegemonic social, political, economic, and military warfare waged against them by the US. North Korea, historically an isolationist state, has always turned inward-economically, politically, ideologically-to buttress itself against foreign influence and interference, for example, against the US after WWII and the waves of sociopolitical and economic destabilization/neutralization of the communist bloc during and after the dissolution of the USSR. In light of the US "victory" over the USSR, the DPRK did the following to not suffer the same fate as the defunct USSR:

The DPRK fell back on an extremely competent system of indoctrination, intimidation, and incarceration to thwart any possible infection from the Tiananmen or glasnost viruses. It attempted to maintain an information blockade for all but the most loyal of its citizens ... draw on Korean history to play up nationalist fears of outside intervention ... As an added deterrent, the government relied on a large and offensively structured military to discourage external attempts to effect regime change. $^{336}$

\footnotetext{
${ }^{335}$ See US National Security Council, "NSC 68: United States Objectives and Programs for National Security, April 14, 1950: A Report to the President Pursuant to the President's Directive, January 31, 1950," Naval War College Review, Vol. 27 (May-June 1975) 51-108, 12 June $2007<\mathrm{http} / /$ www.mtholyoke.edu/acad/intrel/nsc-68/nsc68-1.htm>.

${ }^{336}$ Feffer, North Korea 59. Also, see Roy Richard Grinker, Korea and Its Futures (New York: St. Martin's Press, 1998).
} 
The experience of the Korean War and the continual threat posed by the US to the sovereignty of the DPRK since its founding have resulted in militarization being accorded the highest priority by the North Korean leadership. ${ }^{337}$ Indeed, the military plays an indispensable role in social, political, economic, cultural, ideological, and military functions; for example, it plays a key role in socializing, training, and educating the young via fostering patriotism to the state, and inculcating loyalty to the Kim clan and the military leadership. ${ }^{338}$

Proliferation and militarization in general are roundly condemned by the US, even though it has one of the largest standing armies and is one of the world's most prolific manufacturers and suppliers of arms in the world. According to the Stockholm International Peace Research Institute (hereinafter, SIPRI):

World military expenditure in 2005 is estimated to have reached $\$ 1001$ billion at constant (2003) prices and exchange rates, or $\$ 1118$ billion in current dollars. This corresponds to $2.5 \%$ of world GDP or an average spending of $\$ 173$ per capita. World military expenditure in 2005 represents a real terms increase of $3.4 \%$ since 2004 , and of $34 \%$ over the 10 -year period $1996-$ 2005. The USA, responsible for about $80 \%$ of the increase in 2005 , is the principal determinant of the current world trend, and its military expenditure now accounts for almost half of the world total. The process of concentration of military expenditure continued in 2005 with a decreasing number of countries responsible for a growing proportion of spending: the 15 countries with the highest spending now account for $84 \%$ of the

\footnotetext{
${ }^{337}$ Bertil Lintner, Great Leader, Dear Leader: Demystifying North Korea Under The Kim Clan (Chiang Mai: Silkworm Books, 2005) 93-94.

${ }^{338}$ James E. Hoare and Susan Pares, North Korea in the $21^{\text {st }}$ Century: An Interpretative Guide (Kent: Global Oriental, 2005) 11. See CIA World Factbook Statistics: North Korea. Military branches: North Korean People's Army: Ground Forces, Navy, Air Force; civil security forces (2005). Military service age and obligation: 17 years of age (2004). Manpower available for military service: Males age 17-49: 5,851,801; Females age 17-49: 5,850,733 (2005 est.). Manpower fit for military service: Males age 17-49:4,810,831; Females age 17-49: 4,853,270 (2005 est.). Manpower reaching military service age annually: Males age 18-49: 194,605; Females age 17-49: 187,846 (2005 est.). Military expenditures - percent of GDP: Not Available, US Central Intelligence Agency, CIA World Factbook, 12 Feb. 2007 $<$ www.cia.gov/cia/publications/factbook/geos/kn.html>.
} 
total. The USA is responsible for $48 \%$ of the world total, distantly followed by the UK, France, Japan and China with 4$5 \%$ each. $^{339}$

For the US, militarization is considered a legitimate and absolutely necessary exercise. For "undesirable" states, the very same phenomenon is viewed with disdain, as an inherently dangerous enterprise. Yet, the history of rogue states, especially explicit US interference in their domestic affairs, in conjunction with the US $A S A$, provides a different explanation for militarization other than the "fact" that rogue states arm to threaten global freedom and peace. Analysts such as Nicholas Eberstadt, for example, perpetuate a particular interpretation of rogue states that militarize. In the case of North Korea, he declares that the DPRK is "a state unlike any other-a political construct especially and particularly built for three entwined purposes, [that is,] to conduct a war, to settle historical grievances and to fulfill a grand ideological vision."340 Such pronouncements emerge from an "objective" analysis based on military expenditures, the number of people under arms, and length of compulsory military service the state requires. Yet, the description and the concerns of rogue states proffered by Eberstadt, that is, to conduct war and fulfill a grand ideological vision, can be equally applied to any

\footnotetext{
${ }^{339}$ Stockholm International Peace Research Institute, Recent Trends in Military Expenditure: World Military

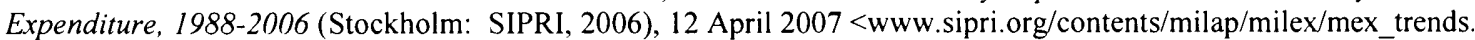
html>. Also, see CIA World Factbook: United States. Military branches: Army, Navy and Marine Corps, Air Force, and Coast Guard; note - Coast Guard administered in peacetime by the Department of Homeland Security, but in wartime reports to the Department of the Navy. Military service age and obligation: 18 years of age; 17 years of age with written parental consent (2006). Manpower available for military service: males age 18-49: 67,742,879; females age 18-49: 67,070,144 (2005 est.). Manpower fit for military service: males age 18-49: 54,609,050; females age 18-49: 54,696,706 (2005 est.). Manpower reaching military service age annually: males age 18-49: 2,143,873; females age 18-49: 2,036,201 (2005 est.). Military expenditures - percent of GDP: 4.06\% (2005 est.), US Central Intelligence Agency, The World Factbook, 13 Feb. 2007 <https://www.cia.gov/cia/publications/factboo k/geos/us.html>.

${ }^{340}$ Nicholas Eberstadt, "What Surprise? The Nuclear Core of North Korea's Strategy," Washington Post, 1 March 2005.
} 
other state, including the US (which spent $\$ 417.4$ billion on military expenditures compared to $\$ 1.8$ billion by North Korea in 2003$).{ }^{341}$ It certainly is the case that the military plays an important part in North Korean affairs, but that role goes beyond merely having an offensive capability. The military's pronounced role is also shaped by and is part of the historical culture and identity of the North Korean state. North Korea is a "garrison society," forged in the fires of military struggle — initially against the Japanese imperialists and then against the US and its South Korean "ally."

These battles have required enormous sacrifices. However much legitimacy the government could claim for its social programs (the land reform after World War II, the economic rebound after 1953), the chief source of its pride has been the ability to prevent the modern-day equivalent of the nineteenth-century imperialists from once again seizing the country... [F]ew other countries in the world [(with the exception of Cuba)] have weathered the full bore of American power or continued to face the sheer amount of military hardware that the US assembled for its posture of containment in the Asia-Pacific region. What might seem like paranoia [on behalf of North Korea] is common sense for a country that suffered near total destruction in the Korean War. ${ }^{342}$

Militarization is therefore less about "evil" and posing a threat to global peace and freedom than it is about state survival, self-interest, self-preservation, security, and rational development of effective military technologies to preserve the state against internal and external threat-in short, those values and interests that are pursued by all states in an anarchic world.

\footnotetext{
${ }^{341}$ Stockholm International Peace Research Institute, Military Expenditure Database 2004 (Stockholm: SIPRI, 2004), 15 April $2007<\mathrm{http}: / /$ web.sipri.org/contents/milap/milex/mex_data_index.html $>$.

${ }^{342}$ Feffer, North Korea 60-61; Bruce Cumings, Korea's Place in the Sun: A Modern History (New York: W.W. Norton, 2005).
} 
An absolutist and aggressive US security policy as manifested in the Bush Doctrine and the war on terror has the effect of aggravating tensions, fueling global militarization and proliferation. The US ASA does not give credence to notions of state sovereignty and a diversity of state interests. In North Korea, fear "of failure and loss of nationhood - and the perceived importance of the military in preventing such scenariossurvived Kim Il Sung's death in 1994." ${ }^{343}$ The military, premised on resistance against US aggression, is therefore a key component of the North Korean regime, and exercises tremendous power in the articulation of North Korean offensive/defensive policy. "North Korea today simply pays lip service to the importance of the party, but the signs of the rise of the military are everywhere, and the military presence can be felt in all aspects of social and political life."344 Indeed, the People's Army maintains a second economy "devoted to its own welfare ... Overseas sales of arms, weapons and even missiles, produced within the DPRK, which have been going on since the $1980 \mathrm{~s}$, are presumed to pass through its hands and its own banking institutions. Its clients are said chiefly to be a number of Middle Eastern and African states." 345

In light of the $A S A$ pursued by the US after 9/11, in 2003 North Korea officially emphasized the role of the military and militarization in maintaining the struggle against the US by privileging a "military-first policy" over economic development. "North Korea switched from a policy of kangsong taeguk (strong military, strong economy) to a

\footnotetext{
343 John Feffer, North Korea 61.

${ }^{344}$ Dae-Sook Suh, "The Military-First Politics of Kim Jong Il," Asian Perspective 26.3 (2002) 146 (Masan, Kyungnam University)..

${ }^{345}$ Hoare, Century 58.
} 
military-first doctrine $[($ songun $)] . " 346$ Songun chongchi means to "give a priority to the military in politics." 347 Military-first signifies a politics, economy, cultural and political structure, and a leadership that places primary emphasis on the military throughout society in order to buttress and preserve society from foreign aggression. In 2003 , the North Korean military absorbed $15.4 \%$ of the 2003 budget ( $25 \%$ of GDP), up from $14.9 \%$ in $2002 .^{348}$ In 2005 , the military was estimated to absorb between $20 \%$ and over $30 \%$ of the economy's Gross National Income (GNI). ${ }^{349}$ North Korea has the $5^{\text {th }}$ largest standing army in the world. More than $1 / 20^{\text {th }}$ of the population serves in the armed forces in some capacity, with 7.45 million ( $30 \%$ of the population between the ages of $15-60$ ) reserve soldiers available for active duty, and a recent estimate noted that North Korea has approximately 4,000 tanks, 2,500 armored personnel carriers, nearly 1,000 naval vessels, and 1,700 aircraft. ${ }^{350}$

Despite being a militarized state, North Korea is a very poor, developing country. In order for it to invest in, develop, and maintain such a large military, North Korea has engaged in a variety of activities, such as bringing in nearly $\$ 1$ billion in the 1990 s from sales of arms to "undesirable" states such as Libya, Iran, the former Iraq, and Egypt,

\footnotetext{
${ }^{346}$ Feffer, North Korea 151; Hoare, Century 12; Tim Beal, North Korea: The Struggle Against US Power (London: Pluto Press, 2005) 92.

${ }^{347}$ See Dae-Sook, "Military-First."

348 See Alex Vatanka, "North Korea Special Report,” Jane 's Sentinel, 20 Feb. 2003, 39-79; "North Korea Boosts Military Spending as Nuclear Crisis Persists," Agence France-Presse, 27 March 2003, 15 Aug. $2007<$ http://209.85.16 5.104/search? $q=$ cache:TckWeMaHKMYJ:www.integrasyssa.com/Press/spacedaily 2003 Headlines.pdf + North + Korea +

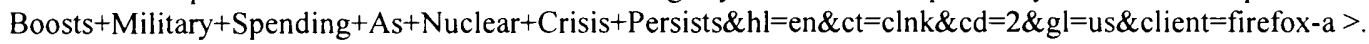

${ }^{349}$ Charles Wolf, Jr., and Kamil Akramov, North Korean Paradoxes: Circumstances, Costs, and Consequences of Korean Unification (Santa Monica: Rand Corporation, 2005) 5-6, 13-14; Eugene J. Palka and Francis A. Galgano, North Korea: Geographic Perspectives (Guilford: McGraw Hill, 2004).

${ }^{350}$ See Joseph Bermudez, The Armed Forces of North Korea (New York: I.B. Tauris, 2001); "North Korea Boosts Military Spending As Nuclear Crisis Persists," Agence France-Presse, 27 March 2003; Nicholas Eberstadt and Judith Bannister, The Population of North Korea (Berkeley: Institute of East Asian Studies/University of California Press, 1992); John Feffer, North Korea 61-65.
} 
while also developing offensive nuclear capabilities and stockpiling a significant amount of biological and chemical WMD. ${ }^{351}$ US policy actively and aggressively isolates North Korea (diplomatically and economically), fueling North Korea's most lucrative industry, that is, trafficking in weapons, especially with Pakistan and countries in the Middle East such as Iran and Egypt (Egypt being North Korea's oldest and closest partner). ${ }^{352}$ As early as 1965 , with the Korean War still fresh in his memory, Kim Il Sung inaugurated the Hamhung Military Academy to conduct research into missile technology. In a speech before the academy, he declared: "If war breaks out, the US and Japan will also be involved. In order to prevent their involvement, we have to be able to produce rockets which fly as far as Japan. Therefore it is the mandate of the Military Academy to develop mid and long range missiles. ${ }^{353}$ A militarized state engaging in illicit activities has, therefore, arisen in direct response to US policy in the Asia-Pacific region, and toward the DPRK in particular. To assume that US policy is not constitutive of the tension, conflict, acrimony, violence, and potential for war and destabilization of the Korean peninsula is to be ensnared in the munificent assumptions, values, norms, morality, and epistemology of the US $A S A$.

In her dealings with North Korea, former US Secretary of State Madeleine Albright observed that brinksmanship is a North Korean specialty. ${ }^{354}$ The nuclear

\footnotetext{
${ }^{351}$ See Daniel Pinkston, "Domestic Politics and Stakeholders in the North Korean Missile Development Program," Non-Proliferation Review: Center for Non-Proliferation, Monterey Institute for International Studies (Summer 2003) 1-15, 16 Aug. $2007<$ cns.miis.edu/pubs/npr/vol10/10 2/102pink.pdf>

${ }^{352}$ See Joseph Bermudez, Shield of the Great Leader: The Armed Forces of North Korea (Sydney: Allen and Urwin, 2001) 252-253.

${ }^{353}$ Kim Il Sung quoted in Bermudez 238. Also, see Beal 113-115.

${ }^{354}$ Madeleine Albright, Global Viewpoint, 9 Jan. 2003, 4 March $2007<$ http://www.digitalnpq.org/global_services/glo bal\%20viewpoint/01-09-03.html>.
} 
confrontation between North Korea and the US is not the result of an evil, irrational North Korea. North Korean resistance to US unipolar management of global order is not so much the result of an iniquitous, failing state that seeks nothing more than to threaten civilized international order. Rather, the "confrontation takes place against a backdrop of historical, cultural, ethical, and practical premises and realities that need to be taken into account." 355 The nuclear (as well as sociopolitical, ideological, and economic) confrontation between the US and North Korea can be better understood if viewed as a manifestation of a conflict between two irreconcilable worldviews. One worldview is represented by the DPRK. The DPRK tenaciously adheres to what has been a hallmark of international relations, that is, a Westphalia system of sovereign states. It demands a right to exist and pursue its self-interest free of US oversight, recrimination, threat, and sanctions (as with other rogue states). Perhaps, quite ironically, the longest running enemy of the US-the North Korean state-is more of a "genuine" state vis-à-vis official state-to-state interactions, policies, rationalizations, and justifications for its right to exist, than the staunch defender of the new world order, that is, the US.

The DPRK's struggle to survive the onslaught of US power is based upon principles, precepts, and a philosophy embedded in the Westphalia system, which, at its most basic level, posits that international order is comprised of sovereign states "equal" in their functional sovereignty. In theory and practice, sovereignty includes a state's right to self-defense, self-determination, prohibits forcible external interference within a state's domestic affairs, and postulates that war and violence is justified when a state is

\footnotetext{
${ }^{355}$ Beal 202. Regarding the US role in the Korean War and Soviet interference in Korea affairs, see Cumings, Place 185-298.
} 
confronted with unwarranted aggression. ${ }^{356}$ The unipolar and absolutist posture of the US views world society as a forum for the implementation of its singular agenda. The US $A S A$ views international affairs as follows:

the world [is] centered on a [single] state representing civilization and good governance, surrounded by subordinate states. If the legitimacy of the rulers of these states is endorsed by the [hegemonic] power then they are allowed arms ... and are considered as 'members of the international community.' The others, whose legitimacy is not recognized are called ... 'rogue states. ${ }^{357}$

The DPRK, a demonized rogue state, cannot legitimately pursue national survival and engagement in the world economy. DPRK efforts to negotiate with the US and shut down its program to develop NW, according to the DPRK, have to encompass: 1 , recognition of the DPRK's sovereignty, 2., assurance of nonaggression, and 3., the US must cease its continuous ideological and economic warfare on the DPRK by allowing it to participate in the states system, especially global trading in the world economy.

In light of US aggression and a sustained massive military presence on the Korean peninsula, it should not come as a surprise that offensive NW have been sought by North Korea. After the fall of Baghdad, former US Defense Secretary Donald Rumsfeld warned North Korea to draw an "appropriate lesson" from the US invasion. ${ }^{358}$ A rational state actor would realize that only something as profound as a nuclear deterrent could

\footnotetext{
${ }^{356}$ See "Treaty of Westphalia, October 24, 1648," The Avalon Project at Yale Law School 1996, 12 July $2007<$ www. yale.edu/lawwe b/avalon/westphal.htm $>$.

${ }^{357}$ Beal 217.

${ }^{358}$ Randeep Ramesh, "The Two Faces of Rumsfeld,” The Guardian, 9 May 2003.
} 
prevent unilateral US military aggression in a unipolar world. Also, the US Nuclear Posture Review 2002 identified North Korea (in addition to other non-nuclear states) as being first among countries that could be the target of an unprovoked nuclear strike: "North Korea, Iraq, Iran, Syria, and Libya are among the countries that could be involved in immediate, potential, or unexpected contingencies." ${ }^{359}$ In light of such policy, a

key factor driving [development of] WMD is the nationalist backlash against economic, [social, political, and cultural] globalization and its challenges to the state's primacy ... [NW] are not simply a path to military parity or superiority. They are a way for middle powers to emphasize their independence and attain equal status in the international system ... WMD can compensate for the lack of economic and cultural independence ... North [Korea], anxious about [its] deteriorating position $\ldots$ [is] eager to have boost to its] prestige and status in the world. ${ }^{360}$

It must be kept in mind that North Korea's security is at the apex of its nuclear agenda. "It was security from attack, normalization of relations with the US, the ending of US economic warfare, and energy aid" that initially guided the development of WMD. ${ }^{361}$

After the fall of the USSR and the subsequent terrorist attacks on the US on 9/11, the US found itself in a position where it had

had fewer constraints on the use of military force, particularly aerial bombing and missile attacks. It seemed to have no problem attacking non-nuclear states that possessed large armies and conventional forces (Iraq, Serbia) but generally fell back on diplomacy to handle competitors with nuclear weapons such as

\footnotetext{
${ }^{359}$ US Department of Defense, Nuclear Posture Review 2002, 2 Aug. 2007 <www.globalsecurity.org>.

${ }^{360}$ Feffer, North Korea 135.

${ }^{361}$ Beal 215 .
} 
Russia and China. A nuclear weapon would make sense to Pyongyang as a trump card to play if all else failed. ${ }^{362}$

As John Feffer observes, North Korea had witnessed firsthand the US tendency of "taking advantage of weak adversaries. And it had also seen in the developing world that weak countries languish in poverty despite decades of 'development aid.' Only substantial deterrence-in the form of nuclear weapons and the missiles to deliver them-offered the ultimate promise of dissuading the US from using its stick on Pyongyang and providing real development assistance." 363 North Korea's military strategy, however, while incorporating NW for deterrent purposes, also seeks other goals that are not "irrational." In particular, North Korea's international military and armament strategies are derived from domestic strategies and concerns that are "intended to achieve goals and conditions that satisfy national interests. Military strategies reflect capabilities vis-à-vis potential opponents, resource constraints, and desired end states. North Korea is no different [than other states]; its military strategy is a reflection of Pyongyang's national goals." ${ }^{364}$ Military strategies also reflect what Peter Katzenstein has termed "cultural rules of engagement," that is, military strategies are based on socially

\footnotetext{
${ }^{362}$ Feffer, North Korea 62. Also, see Wendy Sherman, "Sunshine Through Cloudy Skies," Asian Perspective 26.3 (2002) 7; Bruce Cumings, Parallax Visions: Making Sense of American-East Asian Relations at the End of the Century (Durham: Duke University Press, 1999); Selig S. Harrison, "The Missiles of North Korea," World Policy Journal 17 (Fall 2000) 13-24.

${ }^{363}$ Feffer, North Korea 65. Also, see Nicholas Eberstadt, "Tear Down This Tyranny," Weekly Standard, 29 Nov. 2004; William Kristol, "Toward Regime Change in North Korea," Project For the New American Century, 22 Nov. 2004, 16 Aug. $2007<\mathrm{http}: / /$ www.newamericancentury.org/eastasia2004.htm>.

${ }^{364}$ Homer T. Hodge, "North Korea's Military Strategy," Parameters: US Army War College (Spring 2003) 68-81, 16 Feb. $2007<$ http://www.carlisle.army.mil/usawc/Parameters/03spring/hodge.htm>.
} 
constructed cultural precepts unique to a particular nation. ${ }^{365}$ In the case of North Korea, the regime has sought to reunify the Korean Peninsula on North Korean terms. Indeed, the regime's constitution describes reunification as "the supreme national task," and reunification remains the case under the present leadership. ${ }^{366}$

In addition to protecting itself from US attack and the goal of reunifying Korea, North Korea also seeks to complete its revolution. When North Korean leaders speak of achieving "socialist revolution in our country," they are referring to the unification of the entire peninsula on their terms.

North Korea considers the entire peninsula as constituting its sovereign territory. It does not recognize South Korea as being a separate nation, nor the government of South Korea as legitimate. Therefore, when North Korea refers to 'our country' or the 'fatherland,' they mean the entire Korean peninsula ... [and the] southern half of their country as occupied by 'US imperialists' and the government of South Korea as 'puppets serving their imperialist masters.' 'Defense' does not refer to defending North Korea, but to defending all of Korea. Accordingly, 'defense of the fatherland' means (1) reclaiming that portion of Korea [(the south)] that is currently occupied and controlled by the 'imperialists,' and (2) defending against further encroachment by 'US imperialists. '367

The security context that has emerged in light of $9 / 11$ premises US policy and action on interference in the affairs of any state deemed a threat, paying no heed to the interests of sovereign states (hostile and non-hostile), ignoring history, culture, the US role in

\footnotetext{
${ }^{365}$ Peter J. Katzenstein, "Introduction: Alternative Perspectives on National Security," The Culture of National Security: Norms and Identity in World Politics, ed. Peter J. Katzenstein (New York: Columbia University Press. 1996).

${ }^{366}$ Socialist Constitution of the Democratic People's Republic of Korea (Pyongyang: Foreign Language Publishing House, 1998) cited in Hodge, "Strategy."

${ }^{367}$ Hodge "Strategy."
} 
producing conflict and destabilization, and disregarding the sundry states of affairs that pre-exist unsolicited interference. After denouncing Kim Jong Il as a "pygmy" and declaring, "I loathe Kim Jong Il! I've got a visceral reaction to this guy ... Maybe its my religion ... but I feel passionate about this," US President George W. Bush proceeded to express his earnest desire for "toppling" Kim's regime. ${ }^{368}$ The DPRK responded by withdrawing from the NPT and announced in June of 2003 that it was officially pursuing nuclear weapons capacity. North Korea went on to assert that it has "no option but to have a nuclear deterrence if the US keeps its hostile policy and continues its nuclear threat toward the DPRK., ${ }^{369}$

Conclusion

An absolutist security policy has, therefore, explicitly contributed to NW proliferation in the Asia-Pacific region, and overall instability on the Korean peninsula. North Korea has therefore considered its nuclear and missile programs as bargaining chips and/or deterrents to be used against its enemies; "on the evidence of the last decade, the deterrent of a possible nuclear weapon has been demonstrably effective: no one has invaded or bombed [a nuclear] country." ${ }^{370}$ On March 29, 2003, Rodong Sinmun reported that North Korea "would have already met the same miserable fate as Iraq's, had it accepted the [unqualified and unilateral] demand raised by the imperialists for nuclear inspection and disarmament ... and that it would increase defense capacity as the

\footnotetext{
${ }^{368}$ George W. Bush quoted in Bob Woodward, Bush at War (New York: Simon \& Schuster, 2002) 340.

${ }^{369}$ Korean Central News Agency, Agence-France Presse, Seoul, 9 June 2003, 1 August $2007<$ http://www.kcna.co.jp/i ndex-e.htm>.

${ }^{370}$ Feffer, North Korea 156.
} 
country's number one lifeline." ${ }^{371}$ An absolutist US posture, with the ominous threat of destabilizing and toppling the North Korean regime, has played a direct role in North Korea's developing and obtaining offensive WMD (especially NW).

\begin{abstract}
North Korea has the capability to produce medium-range missiles, chemical weapons, and biological weapons, and tested its first nuclear device on October 9, 2006. The test came less than one week after the October 3, 2006 'clarification statement' by the North Korean Foreign Ministry declaring Pyongyang's intention to conduct a nuclear test. The Korean Central News Agency announced that the October 9 test was conducted at a 'stirring time when all the people of the country are making a great leap forward in the building of a great prosperous powerful socialist nation. ${ }^{, 372}$
\end{abstract}

Seeking engagement with the US on its own terms, amongst other interests, motivates the nuclear aspirations of North Korea as well as possessing a means to deter military attacks by the US. "To pose a credible threat and deter US intervention or aerial assault, North Korea is deeply invested in projecting [an] image of aggressive competence. ${ }^{\text {373 }} \mathrm{A}$ classic brinkmanship in-crisis-lies-opportunity framework seems to underlie the rationale for engagement with and procuring economic aid/incentives from the US and its allies while maintaining North Korean autonomy/identity via the development and testing of functional and offensive nuclear weapons. ${ }^{374}$

\footnotetext{
${ }^{371}$ Aidan Foster-Carter, “Analysis: North Korea's Move," BBC News Online, 16 April 2003, 15 Aug. $2007<$ www.bb c.com>.

${ }^{372}$ Center For Non-Proliferation Studies, WMD Country Profiles Database, 17 Aug. $2007<\mathrm{http}: / / \mathrm{cns}$.miis.edu/dbinfo/ about.htm>.

${ }^{373}$ Feffer North Korea 66.

${ }^{374}$ Hoare 125-132.
} 
North Korea's development and testing of nuclear weapons is viewed with utter disdain by the US. The US cannot and will not abide any rogue state obtaining the means to effectively challenge its prerogatives. Christopher R. Hill, Assistant US Secretary of State for East Asian and Pacific Affairs, has declared that, the US is "not going to live with a nuclear North Korea, [the US] will not accept it."375 North Korea therefore has a very clear choice, that is, conform or be explicitly and perpetually targeted for destabilization. "North Korea can have a future or it can have these weapons. It cannot have both." ${ }^{376}$ Under incessant and hostile US pressure, it is assumed by the US that the dismal state of North Korea's conventional armed forces (due to a languishing economy for the last several decades and severe natural disasters such as the mass famine that occurred in the 1990s) will supposedly result in destabilization and the eventual obliteration of North Korea. Yet, the struggle against an unyielding enemy (the US) has defined North Korea (politically, militarily, socially, economically) since its inception; the US has always been the DPRK's nemesis, looming over and threatening its very existence. $^{377}$

North Korea has consistently utilized a variety of strategies to maintain its sovereignty and security in addition to developing NW. During the Cold War, the North:

\footnotetext{
${ }^{375}$ David E. Sanger and Jim Yardley, "US Sternly Warns North Korea Not To Conduct A Nuclear Test," New York Times, 5 Oct. 2006.

${ }^{376}$ Sanger, "Sternly." For a general discussion of global security vis-à-vis regions, see Barry Buzan and Ole Wæver, Regions and Powers: The Structure of International Security (Cambridge: Cambridge University Press, 2003).

${ }^{377}$ For examples covering this topic, see "Rag-Tag Army Forced to Survive on Paltry Funds," South China Morning Post, 10 April 1999; Jae-Jung Suh, "Blitzkrieg or Sitzkrieg? Assessing A Second Korean War," Pacifica Review 11.2 (1999) 151-176, Lee Sung-yul, "Antique North Korean Naval Boats No Match for South's New Warships," The Korea Herald, 7 July 1999; Eric Schmitt, "North Korean Fliers Said to Have Sought Hostages" New York Times, 8 March 2003; Kongdan Oh and Ralph Hassig, North Korea Through the Looking Glass (Washington D.C.: Brookings Institution, 2000).
} 
juggled its relations with China, Russia, and the $3^{\text {rd }}$ World to achieve the greatest benefits from all three. After 1989, it tried to adapt this ... strategizing to the democratic world. Central to this new diplomatic approach was improved relations with the US ... In the 1970's, it hoped for a breakthrough in relations with the US as a kind of corollary to the Washington-Beijing détente. More recently, North Korea has identified the US as the chief power-broker in the Asia-pacific region and has accordingly focused attention on concluding a bilateral deal. ${ }^{378}$

The US, however, cannot and will not in good faith engage an "evil" state that by virtue of its existence poses an inherent "threat" to global peace, order, and security. While engagement in the form of diplomatic relations and recognition, trade, incorporation into the world economy and the US-managed society of states, and the like, could be utilized by the US to bring North Korea into mainstream world order, giving it a degree of "agency," such a policy is anathema to US morality. "Staying the course" of perpetual US aggression comprised of militarization, force, hostility, containment, propaganda, psychological, and economic warfare, North Korea proceeded to detonate a nuclear device on October 9 2006. North Korea, one of the world's poorest and most isolated countries, lives in constant fear of being subsumed by US power. Having offensive nuclear capability has enabled North Korea to present a viable and credible threat in retaliating against US aggression. North Korea's leadership "had their military plan to demonstrate that no one could [intimidate] them, and they weren't going to be deterred, not even by the Chinese ... In the end, there was just no stopping them." ${ }^{, 379}$ Since the

\footnotetext{
${ }^{378}$ Feffer, North Korea 82.

${ }^{379}$ David E. Sanger, "North Korea Reports First Nuclear Arms Test," New York Times Online, 9 Oct. 2006, 14 August $2007<$ www.nytimes.com/2006/10/09/world/asia/09korea.html?n=Top $\% 2$ fNews\%2f World $\% 2 \mathrm{fCountries} \% 20$ and $\% 20$ Territories $\% 2 \mathrm{fNorth} \% 20$ Korea>.
} 
founding of the North Korean state, Kim Il-sung was "determined to [counter] the power of the United States, and [was] acutely aware that General Douglas MacArthur had requested nuclear weapons to use against his country." 380 According to the DPRK state media, the DPRK's "intention to build up a nuclear deterrent force is not aimed to threaten and blackmail others but reduce conventional weapons under a long-term plan and channel manpower resources and funds into economic construction and the betterment of people's living." 381 The acquirement of NW has enabled regimes that were not necessarily in line with the US unipolar project (for example, Pakistan) to engage the US and the states system.

Proliferation is one of a variety of negative effects that have devolved from an aggressive, hegemonic, unilateral foreign policy. Proliferation under the US $A S A$ has occurred due to considerable, unsolicited interference in the affairs of enemy states. Such interference is not in line with a states system notion that allocates a modicum of sovereignty to its constituent parts, that is, individual states. Although the US has a long history of foreign intervention, the US strategy has exponentially grown, evolved with the advent of 9/11. Aggressive and explicit interference in other states' affairs and US hyper-nationalism have reached unprecedented proportions, and inform the current policy against North Korea, other rogue states, and any and all enemies of the US. Explicit US interference in the internal and external affairs of states, rogue states in particular, has generated violent resistance to US policy, sustaining and fueling the very thing that the

\footnotetext{
${ }^{380}$ Sanger, "Nuclear."

381 "KCNA on DPRK's Nuclear Deterrent Force," Korean Central News Agency, 9 June 2003, 16 Aug. 2007 $<\mathrm{http}$ //www.kcna.co.jp/index-e.htm>.
} 
US seeks to repress, that is, challenges to its supremacy and security. ${ }^{382}$ The hypernationalist dimension of the US ASA provides grist for the mills of insecurity vis-à-vis WMD and NW. Indeed, as Gellner notes, it is the case that nationalism assumes an indispensable and profound

role in regime preservation because it is primarily a political principle, which holds that the political and the national unit should be congruent. Nationalism as a sentiment, or as a movement, can be best defined in terms of this principle. Nationalist sentiment is the feeling of anger aroused by the violation of the principle, or the feeling of satisfaction aroused by its fulfillment. A nationalist movement is one actuated by a sentiment of this kind. ${ }^{383}$

While hyper-nationalism is condemned by the US, in practice it is as virulently nationalist as the global enemies of peace and freedom. The US $A S A$ holds that while it is justifiable for the US to implement its nationalist policy at the global level, the US is exempt from having to give credence to what it deems "unacceptable" nationalism. Rogue states are therefore epistemic constructs, creations of US policy; the very notion of a rogue state is derived from a US-based definition of global security/society. Each rogue state, before becoming "rogue," has experienced US interference, whether explicitly or implicitly, and has, in turn, developed internal political systems premised on hyper-nationalist hostility toward that interference.

\footnotetext{
${ }^{382}$ Examples of sustained and significant US interference in the internal (and external) affairs of a variety of states abound in the historical record. See Frank A. Ninkovich, The United States and Imperialism (Oxford: Blackwell, 2001); John Rees, Imperialism and Resistance (New York: Routledge, 2006); Thomas Kane, Theoretical Roots of US Foreign Policy: Machiavelli and American Unilateralism (New York: Routledge, 2006).

${ }^{383}$ Ernest Gellner, "Nations and Nationalism," Conflict After the Cold War: Arguments on Causes of War and Peace $2^{\text {nd }}$ ed., ed. Richard K. Betts (New York: Pearson-Longman, 2005) 307. Also, see J. S. Mill, Considerations on Representative Government (London: Parker, Son, and Bourn Publishers, 2006).
} 
In the Asia-Pacific region, "the US sword, by far the strongest in the region (indeed, the strongest in the world), is regularly waved in the air to reassure allies and threaten adversaries. At the same time, US policy is billed as defensive. [Within the region,] US troops, bases, and the $7^{\text {th }}$ Fleet are advertised as a buffer separating the conflict-disposed countries of the region from one another." 384 The US is therefore presented as being indispensable to the stability, integrity, and character of global order by signaling out and subjugating threats to global order, peace, and stability. Yet, in practice its security policy, historically and presently, fosters frustration, hostility, and destabilization by dismantling and disregarding states' sovereignty to suit US interests. Explicit US interference in the internal and external affairs of rogue states is a salient feature of US security that has generated violent resistance to US policy, sustaining and fueling challenges to US supremacy and absolute security.

\footnotetext{
${ }^{384}$ Feffer, North Korea 127. For interpretations of hegemony and regional/global stabilization, see Bradley Martin, "The What-If Question," Nautilus Policy Forum Online, no. 00-02, 15 March 2000, 21 Aug. $2007<$ http://www.nautilu s.org/fora/security/0002 C_Martin.html>; K. S. Nathan, "South Asia and U.S. Security Policy: US Engagement Policy in a Changing Asia," National Defense University's Twentieth Annual Pacific Symposium, 1-2 March I999 (NAPSNET Special Report, 23 July 1999), 21 Aug. 2007 <ttp://www.ndu.edu/inss/symposia/pacific99/ksnathan.html>; Sheldon Simon, "Alternative Visions of Security in Northeast Asia," Journal of Northeast Asian Studies (Fall 1996).
} 


\section{CHAPTER 5. CONCLUSION}

Security is a complex state of affairs, tinctured with subjectivity, diversity, and fragmented along sundry political, ideological, and socio-cultural lines. Given this complexity, the US $A S A$, as an "objective" and ubiquitous system of knowledge and truth, has profound consequences for the conduct of international affairs. In a post-9/11 security context, global security is articulated and promulgated by a single state that is primus inter pares in the international system. The US, the world's only hyper-power, has actively implemented an absolutist security agenda in order to procure an ideal of a zero-risk global security environment vis-à-vis elimination of polymorphous terror and its accoutrements. As discussed and demonstrated in the previous chapters, the US $A S A$, in theory and practice, has weighty consequences for the operative assumptions and practices of a states system, creating a more insecure world. This is the case because, in pursuing absolute security, the US state seeks to unilaterally and militaristically identify, posit, procure, manage, and implement an ideal of an absolutist, zero-risk, and violencefree security context wholly amenable to US interests. The US seeks to emplace security in a totalizing public-safety ideal, with the US as the sole authority competent to articulate and enforce idealistic zero-risk, militarized security policies. By marginalizing and undermining notions such as sovereignty, diversity, and domestic individual and group human and civil rights/liberties, the US assumes a plenipotentiary and quasitotalitarian power of contouring international relations to suit its particular interests. By pursuing an absolutist security agenda, the US state is able to present its security agenda as munificent and necessary, inspired by public safety, effectively retaining a façade of 
traditional ordering principles and concepts of international relations-which are antithetical to an absolutist security agenda-while concomitantly divesting such principles and concepts of their basic realities.

Under the US $A S A$, global security is envisioned as a distinct, absolute system of knowledge, of rectification, whereby the molding and transformation of international actors, based on a single state's standards of reality, produces a distinct unipolar modality of global security. "Reality becomes its own ideology through ... faithful duplication."385 Hence, the US can assert in an evident and munificent manner that:

Homeland security requires a truly national effort, with shared goals and responsibilities for protecting and defending the Homeland. Our Strategy leverages the unique strengths and capabilities of all levels of government, the private and nonprofit sectors, communities, and individual citizens. Mindful that many of the threats we face do not recognize geographic boundaries, we also will continue to work closely with our international partners throughout the world ... Partnerships in homeland security also extend beyond our Nation's borders. International cooperation continues to be an enduring feature of our approach to terrorism and violent extremism ... The US will continue to develop and strengthen foreign partnerships and the homeland security capabilities of our friends and allies. Security at home ultimately is related to security abroad: as partners protect and defend their homelands, the security of our own Homeland increases (emphasis added). ${ }^{386}$

A major consequence of subscribing to the $9 / 11$ war-response is that an objectified US order-combine and its ideational and material accoutrements become internally and externally self-referential, reverential, cyclically reified, disseminated, and

\footnotetext{
385 Adorno 63.

386 The White House, National Strategy for Homeland Security October 2007, 19 Aug. $2008<$ http://www.whitehouse. gov/infoc us/homeland/nshs/2007/index.html>.
} 
grafted onto international order. Loss of the USSR to ballast US power, in conjunction with the spectacle and event of $9 / 11$, has enabled the US to pursue an unfettered $A S A$ to counter terror in the name of all states' security. Yet, the boundless war on terror has severe negative consequences for the stability and security of states in the international system: the incessant "repression of terrorism spirals around as unpredictably as the terrorist act itself. No one knows where it will stop, or what turnabouts there may yet be. There is no possible distinction, at the level of images and information, between the spectacular and the symbolic, no possible distinction between the 'crime' and the crackdown. $" 387$

Under an $A S A$, security is treated as a state of affairs that is both true and believed. This is the epistemological modus operandi of the US ASA and its relationship to producing a global system of security. ${ }^{388}$ The US $A S A$ system of knowledge equates belief and truth with US security, and therefore produces "genuine" knowledge that is universal, incontestable, inexorable, authoritative, and just. The knowledge that devolves from $9 / 11$ as event, image, and moral/ethical judgment is centered around the US trying to establish a globalized police-state based on overwhelming force, panoptic surveillance, and criminalization measures designed to counter terror in any and all of its infinite, polymorphous manifestations. US security has "evolved," so to speak, from being one of a variety of global epistemic modalities of security to assuming an all-inclusive, transcendent signification. In a post-9/11 world, the US $A S A$ summarily and objectively

\footnotetext{
${ }^{387}$ Baudrillard, Spirit 31.

388 See Timothy Chappel, "Plato on Knowledge in the Theaetetus," Stanford Encyclopedia of Philosophy, 7 May, 2005, 27 Dec. $2007<$ http://plato.stanford.edu/entries/plato-theaetetus/\#9>; Plato, "Theaetetus," trans. Benjamin Jowett, Project Gutenberg Release \#I726, April 1999, 27 Dec. 2007, <http://www.gutenberg.org/dirs/etext99/thtus10.txt>; Plato, The Republic, trans. Tom Griffith, ed. G.R.F. Ferrari (Cambridge: Cambridge University Press, 2000).
} 
condemns a state for what it is. ${ }^{389}$ A statement by an affiliate of the Council of Foreign

Relations, James Warburg, seems apt when considering US security and its ASA on the conduct and character of international affairs: "We are willing to become citizens of the world, but only if the world becomes an extension of the US." 390 Such a claim is in line with the US being a "hyper-power," a unipolar structural referent that seeks to impose a uniform and continuous global state of affairs that reflects the priorities, interests, economics, politics, culture, security, and needs of a single state. The US seeks to accomplish this by militarizing the polity. For instance, the US has established an Information Sharing Environment (ISE) which specifically orders all levels of government in the US to have unobstructed data gathering and sharing capacities over anything remotely resembling terror or the potential for terror, and that the national government have the same power with respect to other states. "Today's ISE consists of multiple sharing environments designed to serve five communities: intelligence, law enforcement, defense, homeland security, and foreign affairs," to the detriment of all other competing values and states of affairs. ${ }^{391}$

The proposition that the US ASA = Global Peace \& Freedom, however, is not self-evident; David Hume logically demonstrated that there is no necessary causality that can be identified in any sequence of events (logical, natural, physical, etc.), and that

\footnotetext{
${ }^{389}$ Michel Foucault, Power: Essential Works of Foucault, 1954-1984, Vol. III, trans. Robert Hurley, intro. Colin Gordon, ed. James D. Faubion (New York: New Press, 1994) 70-71.

${ }^{390}$ James Warburg quoted in Clyde Prestowitz, Rogue Nation: American Unilateralism and the Failure of Good Intentions, (New York: Basic, 2003). For analyses that contend the US is a rogue state see Prestowitz, Rogue Nation; T. D. Allman, Rogue State: America at War with the World (New York: Nation, 2004); Michael Klare, Rouge States \& Nuclear Outlaws: America's Search for a New Foreign Policy (New York: Hill and Wang, 1995); "Chomsky Info. The Noam Chomsky Website," 15 April $2008<$ http://chomsky.info/>.

${ }^{391}$ The White House, National Strategy for Information Sharing October 2007, 19 Aug. $2008<\mathrm{http}: / /$ www.whitehouse. gov/nsc/i nfosharing/index.html>.
} 
sequentialness in human affairs is best understood as an additive process as opposed to a causal process. ${ }^{392}$ The US $A S A$, on the contrary, seeks to provide the means whereby, if $A$, then $B$ (that is, if the US $A S A$ obtains, then global freedom and peace obtain) becomes an objective, causal reality. The US $A S A$ ambitiously seeks to initiate "the final phase of the extensions of man - the technological, [political, economic, cultural, juridical, social, and military] simulation of [a singular global] consciousness, when the creative process of knowing will be collectively and corporately extended to the whole of human society. $" 393$

The US $A S A$ functions so as to produce progressive adaptation to its ordering schema of international affairs, molding the category and practice of security based on pliable precepts of fear and loathing of terror and terrorists, and US power as the singular basis for ensuring justice and peace. The US $A S A$ induces ideological conformity via infiltration of the concepts and categories that have traditionally structured international affairs, especially notions of self-determination, state sovereignty, and a diversity of state interests. The "truth" postulated by the $9 / 11$ war-response embodied in the US $A S A$, which leads ineluctably to the "good" and the "just," assumes a multitudinous yet selfcontained referentiality based on tautologically reifying properties, effectively equivocating US domestic security with global security measures. Furthermore, knowledge and truth are producers and products of power; power produces right, good, and justice in order to manufacture a potent machinery of psychic (conceptual) and

\footnotetext{
392 David Hume, An Enquiry Concerning Human Understanding, ed. Tom L. Beauchamp (New York: Oxford University Press, 2006); D. F. Norton, The Cambridge Companion to Hume (New York: Cambridge University Press, 1993).

${ }^{393}$ McLuhan, Understanding 3-4.
} 
corporeal (physical) control. Beneath the veneer of global peace, freedom, and justice, there is a deeper fundament of power and control that must be revealed, disaggregated, and examined. Under a war-on-terror-rubric, the US confidently asserts the primacy, correctness, and inevitability of a US managed global system that supercedes the premises of a states system. Belligerent, proactive, preventive, and illimitable war is the hallmark of the 9/11 war-response to the advent of an "age of terror." There is a clear demarcation between "good" and "evil," the "right" side and the "wrong" side of a binary division of the world into pro-US and anti-US, since the US campaign for democracy, freedom, and global peace embodies all that is universally moral and superior in the world.

The knowledge and modality of global society and global security produced by the US $A S A$ is "not a faculty or a universal structure. Even when it uses a certain number of elements that may pass for universals, knowledge will only belong to the order of results, events, effects. ${ }^{\prime 394}$ The US $A S A$ poses the problem of global security in terms of highly subjective, vague, and relative macro-structural states of affairs, especially justice, freedom, peace, democracy, state-corporate-market system, and stability. The US $A S A$, at the level of rhetoric and justification, does not pose security in terms of a society/system of states. To pose the problem of security within the terms of a particular state results in "sovereignty" being divested of viability, efficacy. For a single state to implement global security creates a context for repressive one-state power apparatuses, such as unfettered police powers, unilateral military incursions and sanctions, and

\footnotetext{
${ }^{394}$ Michel Foucault, Power: Essential Works of Foucault, 1954-1984, Vol. III, intro. Colin Gordon, ed. James D. Faubion, trans. Robert Hurley (New York: New Press, 1994) 14.
} 
selective diplomatic isolation. At its core, the US ASA seeks to graft the moral, ideological, social, economic, and political dictates of a single state upon global society. Thus, "the [9/11] attacks are just a tactic to enable [terrorists] to spread their dark vision of the world ... they will do anything they can to spread that ideology. And it's our charge, it's our calling to keep the pressure on these people, to defend America and to spread an ideology of hope and an ideology of peace. ${ }^{395}$

The US $A S A$ is a modality of global security, of global public safety, that seeks to procure subservience, adherence, and fealty to US power as the singular source for quelling the anarchical international context. 9/11 as event and image has provided a locus whereby traditional US policy can be elevated to a macro level as far as applicability and propriety, especially when considering the moral/ethical and militaristic character of the $9 / 11$ war-response. The US $A S A$ "speaks" to its audience in a manner that co-opts and fixes signification vis-à-vis security concepts, molding security so as to force other states into "the grip of ideas already fixed beforehand ... to reduce the nature of language to a [particular] concept, so that this concept may provide a generally useful view of [security] that will lay to rest all further notions about it." ${ }^{396}$ The US $A S A$ becomes justified in itself, an object of absolute (police) power to repel and prevent polymorphous threats to its order; threat, however, is not an objective condition. ${ }^{397}$

\footnotetext{
${ }^{395}$ George W. Bush, "President Bush Celebrates Independence Day With West Virginia Air National Guard 167th Airlift Wing, C-5 Maintenance Hangar, Martinsburg, West Virginia," The White House, Office of the Press Secretary, Washington, D.C., 4 July 2007, 5 July $2007<$ http://www.whitehouse.gov/news/releases/2007/07/20070704.html>.

${ }^{396}$ Martin Heidegger, "Language," trans. Albert Hofstader, The Norton Anthology of Theory and Criticism, eds. Vincent B. Leitch, William E. Cain, Laurie A. Fink, Barbara E. Johnson, John McGowan, and Jeffery J. Williams (New York: W.W. Norton, 2001) 1I22.

${ }^{397}$ See Hardt, Empire 13; David Campbell, Writing Security: United States Foreign Policy and the Politics of Identity (Minneapolis: University of Minnesota Press, 1998) 1.
} 
The US $A S A$, via analytic, conceptual, material, and variegated discursive media, casts conceptual nets of cognition so as to "capture" and name the objects, forms, and substance of international affairs. Through acts of naming the constituent elements of the world, formative dissertations of knowledge are able to establish "objective" frameworks for global governance. ${ }^{398}$ The US $A S A$, utilizing the conceptual language and signifiers of the Westphalia system, is concomitantly utilizing states-system concepts and principles while emptying them of substantive content. The simulation that is occurring under the US $A S A$ involves the lexicon of the states-system being employed that has no states-system as a reference; rather, a single state forms the referent. The US ASA therefore seeks to co-opt the Westphalia framework within the following successive phases of image-envelopment and simulation: 1., the image of the states-system as a reflection of basic reality, 2., the image as masking and distorting the initial basic reality, 3., masking the absence of the initial basic reality, and 4., the images of the US $A S A$ bear no substantive relation to the initial basic reality being simulated. ${ }^{399}$

It is important to note that the effects and consequences of the US $A S A$ are not relegated to the post-9/11 security context. The concentration and perpetuation of power combined with a paranoiac, absolutist security policy can be observed in the annals of modern history. Communist Albania (1945-1986), Nazi Germany (1933-1945), the USSR (1923-1953), Maoist China (1949-1972), fascist Spain (1939-1975), and Communist Romania (1947-1989) are examples of states that have pursued, to some

\footnotetext{
${ }^{398}$ Meghan L. O’Sullivan, "Replacing the Rogue Rhetoric: A New Label Opens the Way to a Better Policy," Brookings Review 18.4 (Fall 2000) 38-40.

399 Jean Baudrillard, Simulations, trans. Paul Foss, Paul Patton and Philip Beitchman (New York: Semiotext, 1983) 1112.
} 
degree, an $A S A$. Each state experienced negative "blowback" from pursuing an $A S A$, and was unable to sustain such an agenda. In light of the historical record, and the specific case studies discussed in this study, any significant form of absolutist security breeds instability, insecurity, and is deleterious to an ordered international state of affairs; isolationism practiced by Albania, North Korea and Burma, World War II, the Korean and Vietnam Wars, the Gulf Wars, the invasion and occupation of Iraq and Afghanistan - all of these conflicts can be analyzed through the prism of absolutist security.

In light of the discussion and case studies, we can begin to answer the questions that provided the impetus for this study.

Question 1. How is post-9/11 US and global security defined, and has it eclipsed previous notions of security based upon a system of states?

Hypothesis 1. If it is the case that the US is pursuing an $A S A$, then the present global security agenda challenges security notions based on a system of states because an $A S A$ reflects a unipolar world, wherein the values and interests embodied in US security are the basis for global security.

Question 2. Has $9 / 11$ provided an opportunity for the US to implement an absolutist security agenda?

Hypothesis 2. If the US is pursuing an absolutist security agenda, then $9 / 11$ served to legitimate and justify its implementation.

In sum, the current manifestation of US security policy is eroding the traditional conceptual and policy framework that has traditionally defined the international system. Accordingly, global security is now conceived and implemented within an absolutist 
unipolar rubric with the US at the apex of the power-hierarchy in international affairs. $9 / 11$, as event and image, has enabled the US to pursue a moralistic and militaristic crusade based on intangible and non-measurable components such as good, evil, insanity, and hatred.

The US $A S A$ creates viable centers of resistance based on its notion of obtaining absolute security at the expense of any and every state actor in the international system. The US $A S A$ systemically and systematically ignores the diversity of state actors (the cultural, political, economic, juridical, religious, and social variegations, for instance), and seeks to impose a single modality of security. An $A S A$ rubric is unwieldy in that it is an absolutist security project that utilizes vague concepts that have very little substance as independent epistemic indicators, for example, good, bad, wrong, right, foe, friend, threat, terror, evil, just, and immoral. Preemptive, preventive, and unilateral action on the world stage by a unipolar power breaks down the states-system, creating an unstable means of anchoring states in an anarchic system.

This is the case because the vast and potentially limitless homogenizing media of globalization (economic, social, cultural, political, military), combined with US power as the basis for global order via military supremacy, enables the US to monopolize and effectively impose its modus operandi upon the totality of global society. The US thus seeks to import and graft its modality of thought and being on global society via a univocal, unipolar, unilateral, uni-dimensional formulation of global security policy. The US $A S A$, therefore, produces systemic insecurity by forcibly imposing uniformity and a linear, binary, obstinate modality of explaining/understanding security in a post-Cold War, post-9/11 world. The US $A S A$ is unlimited in scope and application, and has the 
capacitance to postulate and envelope any "threat" to the wellbeing and security of the unipolar power; it is a system of security that is cyclical, possessing a universal logic based on internal legitimacy $\longrightarrow$ external legitimacy $\longrightarrow$ internal, ad infinitum, vis-à-vis security. US security is assumed to be contiguous and constitutive of a "shared" universe; under an $A S A$, however, states are "consumed" by the intra-reification of $A S A$ concepts because propositions flow from each other in a logical manner. Prescriptive imperatives of an $A S A$ are presented as axiomatic concepts.

The US $A S A$ arrogates the right to define international security policy for all actors to the US, based on the US's power to control/impose violence, sanctions, military incursions, psychological warfare, propaganda, economic resources, and the like-all legitimate means, media, originating and ending with the unipolar power. State-to-state relations become based on the moral, ideological, economic, cultural, and political template of a single power. In a world that remains characterized by a diversity of state actors, the US $A S A$ breeds virulent violence and conflict based on anti-Americanism in the form of terrorist acts, WMD proliferation, militarization, and strengthening those actors that resist and challenge US power on the world stage. For a single nation to attempt to macro and micro manage the entire world system is logistically unfeasible, resulting in great costs that can weaken rather than strengthen the unipolar state, while also resulting in a loss of legitimacy to "lead" the world community.

It is this study's contention that the Westphalia states-system attempts to ameliorate the insecurity that devolves from an anarchical, self-help system. By "institutionalizing" the notion of sovereignty, states (as well as non-state actors) have been able to situate themselves in an anarchical context, establishing relatively high 
degrees of security given the chaotic nature of the international system, creating stable epistemic and empirical bases of identity and reality formation. When referring to the "institutionalization" of sovereignty, the term is used in what can loosely be termed a "constructivist" sense, that is, an "institution is [viewed as] a relatively stable set or 'structure' of identities and interests. Such structures are often codified in formal rules and norms, but these have motivational force only in virtue of actors' socialization to and participation in collective knowledge. Institutions are fundamentally cognitive entities that do not exist apart from actors' ideas about how the world works." ${ }^{400}$ Furthermore, Alexander Wendt observes that, "it is collective meanings that constitute the structures which organize our actions. Actors acquire identities-relatively stable, role-specific understandings and expectations about self-by participating in such collective meanings. Identities are inherently relational." 401

The institution of state sovereignty embodied in the Westphalia system is under assault by a seemingly benevolent US $A S A$.

Global political and security issues are effectively settled by a directorate of the US [and its allies,] world economic issues by a directorate of the US [and its allies] ... all of which maintain extraordinary close relations with each other, and decisions made at the UN Security Council or in the [IMF] ... are presented as reflecting the desires of the world community. The very phrase 'the world community' has become the euphemistic collective noun (replacing the 'Free World') to give global legitimacy to actions reflecting the [singular hegemonic] interests of the US. ${ }^{402}$

\footnotetext{
${ }^{400}$ Alexander Wendt, "Anarchy is What States Make of It: The Social Construction of Power Politics," International Organization 46.2 (Spring 1992) 391-425.

${ }^{401}$ Wendt, "Anarchy" 392-400.

${ }^{402}$ Samuel P. Huntington, "The Clash of Civilizations," Foreign Affairs 72.3 (Summer 1993); Betts, Conflict 44.
} 
Unilateralism, militarism, preemptive war, preventive war, exceptionally selective and unbridled intervention(s) in other states affairs, imposed political (procedural democracy) and economic (state-corporate managed "free" trade policies, globalization) modalities, morality (the war on terror, freedom, peace) and "correction" policies (for example, targeting rogue states for destabilization, occupation, exploitation, isolation, establishing a presence within rogue states, and an arduous program of political, economic, moral, and social "reeducation") all contribute to the destabilization of a global order that has been based on the implicit and explicit notion of sovereignty as fundamental factor in ordering international affairs. To maintain a critical self-awareness of the media, constructs, power-effects, and control-mechanisms employed to champion a particular notion of truth, right, and justice is, therefore, simply indispensable to the enterprise of explaining and understanding global security in a post-9/11 world. 


\section{BIBLIOGRAPHY}

Abrahamian, Ervand. Iran Between Two Revolutions (Princeton: Princeton University Press, 1982).

Abrahamian, Ervand. Khomeinism: Essays on the Islamic Republic (Berkeley and Los Angeles: University of California Press, 1993).

Abramson, Larry. "The Patriot Act: Alleged Abuses of the Law," National Public

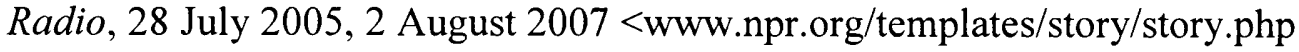
?storyld $=4756403>$.

Acharya, Amitav. "The Bush Doctrine and Asian Regional Order: The Perils and Pitfalls of Preemption," Confronting the Bush Doctrine: Critical Views From the Asia-Pacific, eds. Mel Gurtov and Peter Van Ness (London: Routledge-Curzon, 2005).

Adelman, M. A. The World Petroleum Market (Baltimore: The Johns Hopkins University Press, 1972).

Adorno, Theodore W. The Culture Industry: Selected Essays on Mass Culture, ed. and intro. J. M. Bernstein (London and New York: Routledge, 1991).

Afary, Janet, and Kevin B. Anderson. Foucault and the Iranian Revolution: Gender and the Seductions of Islamism (Chicago: University of Chicago Press, 2005).

Agence France-Presse. "North Korea Boosts Military Spending as Nuclear Crisis Persists," Agence France-Presse, 27 March 2003, 15 Aug. $2007<$ http://209.85. 165.104 /search?q=cache:TckWe MaHKMYJ:www.integrasyssa.com/Press/ spacedaily 2003 Headlines.pdf + North + Korea + Boosts + Military + Spending + As + Nuclear + Crisis + Persists\&hl $=$ en\&ct $=$ clnk\&cd $=2 \& g l=u s \& c l i e n t=$ firefox-a $>$.

Aguilar, Luis. Operation Zapata (Frederick: University Publishers, 1981).

Ahmida, Ali Abdullatif. Forgotten Voices: Power and Agency in Colonial and Postcolonial Libya (New York: Routledge/Taylor Francis Group, 2005).

Akhavi, Shahrough. Religion and Politics in Iran: Clergy-State Relations in the Pahlavi Period (Albany: State University of New York Press, 1980).

Albright, Madeleine. Global Viewpoint, 9 January 2003, 4 March $2007<$ http://www. digitalnpq.org/global_services/global\%20viewpoint/01-09-03.html>.

Albright, Madeleine. The Washington Post, 23 Oct. 1999, 2 April $2008<$ http://www.do ublestandards.org/blum4.html>. 
Algar, Hamid. Religion and State in Iran: 1785-1906 (Berkeley: University of California Press, 1969).

Algar, Hamid. Roots of the Islamic Revolution in Iran: Four Lectures (Oneonta: Islamic Publications International, 2001).

Algar, Hamid. "Transcript of a Four-Lecture Course." The Islamic Revolution in Iran, ed. Kalim Siddiqui (London: Open Press/Muslim Institute, 1980).

Allman, T. D. Rogue State: America at War With the World (New York: Nation, 2004).

Althusser, Louis. "Ideology and Ideological State Apparatuses: Notes Towards an Investigation," trans. Ben Brewster, The Norton Anthology of Theory and Criticism, eds. Vincent B. Leitch, William E. Cain, Laurie A. Fink, Barbara E. Johnson, John McGowan, and Jeffery J. Williams (New York: W.W. Norton, 2001).

Alvarez, Jose E. "Hegemonic International Law Revisited," 97 A.J.I.L. 873, The American Society of International Law, American Journal of International Law (2003) 20 Jan. $2007<\mathrm{http} / /$ web.lexis-nexis.com>.

Amuzegar, Jahangir. The Dynamics of the Iranian Revolution: The Pahlavis' Triumph and Tragedy (Albany: State University of New York Press, 1991).

Anderson, Lisa. The State and Social Transformation in Tunisia and Libya 1830-1980 (Princeton: Princeton University Press, 1986).

Ansell, Meredith O. The Libyan Revolution: A Sourcebook of Legal and Historical Documents (Cambridge: Oleander Press, 1972).

Aristotle. The Politics, trans. Benjamin Jowett, intro. Joseph Carring (New York: Barnes \& Noble, 2005).

Arjomand, Said Amir. The Turban for the Crown: The Islamic Revolution in Iran (Oxford: Oxford University Press, 1988).

Armstrong, Charles. The North Korean Revolution: 1945-1950 (Ithaca: Cornell University Press, 2003).

Aronson, Elliot, Timothy Wilson, and Robin Akert. Social Psychology: The Heart and Mind (New York: Harper Collins, 1994).

Art, Robert J., and Kenneth N. Waltz, eds. The Use of Force: Military Power \& International Politics, $6^{\text {th }}$ ed. (Lanham: Rowman, 2004). 
Ashley, Richard. "The Poverty of Neo-realism," Neo-realism and Its Critics, ed. Robert O. Keohane (New York: Columbia University Press, 1986).

AsianInfo.org. "Establishment of the Republic of Korea," AsianInfo.org., 20 June 2007 $<$ www.asianinfo.org/asianinfo/korea/history/establishment_of_the_republic_of.ht $\mathrm{m}>$.

Associated Press, “Amnesty Accuses Pakistan on Rights," New York Times Online, 20 June 2002, 7 March 2007 <www.nytimes.com>.

Associated Press. "Bush: Putin has 'Derailed' Democratic Reforms: President's Comments Risk Stoking Dispute with Russia Over Missile Shield," Associated Press/MSNBC News Online, 5 June $2007<$ http://www.msnbc.msn.com/id/190 $40836 />$.

Associated Press. “Court Nixes Man's Suit Claiming Torture by CIA: Justices Throw Out German's Challenge to Alleged Abduction by US Agents," MSNBC News Online, 9 Oct. 2007, 10 Oct. $2007<$ http://www.msnbc.msn.com/id/21205942/>.

Avalon Project. "Treaty of Westphalia, October 24, 1648: Peace Treaty Between the Holy Roman Emperor \& the King of France \& Their Respective Allies," Avalon Project Yale Law School 1996, 12 July $2007<w w w . y a l e . e d u / l a w w e b / a v a l o n / w e s$ tphal.htm>.

Ayissi, Anatole N., and Ibrahima Sall, eds. Combating the Proliferation of Small Arms and Light Weapons in West Africa: Handbook for the Training of Armed and Security Forces (Geneva: United Nations Institute for Disarmament Research, 2005).

Bakhash, Shaul. The Reign of the Ayatollahs: Iran and the Islamic Revolution (New York: Basic Books, 1984).

Banathy, Bela. "A Taste of Systemics," The Primer Project: A Special Integration Group (SIG) of the International Society for the Systems Sciences (ISSS) (originally SGSR, Society for General Systems Research) and the International Institute for Systemic Inquiry \& Integration, the First International Electronic Seminar on Wholeness, 1 Dec. 1996 - 31 Dec. 1997, 25 Feb. $2008<$ http://www .newciv.org/ISSS_Primer/asem04bb.html>.

Barbash, Fred, and Peter Slevin. "US Lifts Ban on Travel To Libya," The Washington Post, [Washington D.C.] 27 February 2004, A-16.

Barber, Benjamin. "Jihad vs. McWorld," Conflict After the Cold War: Arguments on Causes of War and Peace, $2^{\text {nd }}$ ed., ed. Richard K. Betts (New York: PearsonLongman, 2005). 
Barber, Benjamin. Jihad vs. McWorld: How Globalism and Tribalism Are Reshaping the World (New York: Ballantine Books, 1996).

Barnes, Barry. The Nature of Power (Cambridge: Polity Press, 1988).

Barthes, Roland. "The Death of the Author," trans. Stephen Heath, The Norton Anthology of Theory and Criticism, eds. Vincent B. Leitch, William E. Cain, Laurie A. Fink, Barbara E. Johnson, John McGowan, and Jeffery J. Williams (New York: W.W. Norton, 2001).

Baudrillard, Jean. Simulations, trans. Paul Foss, Paul Patton, and Philip Beitchman (New York: Semiotext, 1983).

Baudrillard, Jean. The Spirit of Terrorism \& Requiem for the Twin Towers, trans. Chris Turner (London/New York: Verso, 2002).

Beal, Tim. North Korea: The Struggle Against US Power (London: Pluto Press, 2005).

Bearman, Jonathan. Qaddafi's Libya (London: Zed Books, 1986).

Beitz, Charles R. Political Theory and International Relations (Princeton: Princeton University Press, 1979).

Benard, Cheryl, and Zalmay Khalizad. The Government of God: Iran's Islamic Republic (New York: Columbia University Press, 1984).

Benjamin, Jules R. The United States and the Origin of the Cuban Revolution: An Empire of Liberty in an Age of National Liberation (Princeton: Princeton University Press, 1990).

Benson, Thomas W. Writing JFK: Presidential Rhetoric and the Press in the Bay of Pigs Crisis (College Station: Texas A \& M University Press, 2004).

Berger, Peter, and Thomas Luckmann. The Social Construction of Reality (New York: Anchor Books, 1966).

Berger, Samuel R. "A Foreign Policy for the Global Age," Foreign Affairs 79.6 (2000), 6 Feb. $2008<\mathrm{http} / / /$ clinton5.nara.gov/library/hot_releases/January_17_2001_6. html>.

Berlin Information Center for Transatlantic Security. "Analysis on Military, Security, Arms Control, and Non-proliferation Issues," Berlin Information Center (BITS) for Transatlantic Security, 4 March 2007 <http://www.bits.de/index.html>. 
Berlin Information Center for Transatlantic Security. "NATO Nuclear Sharing and the NPT - Questions to be Answered," Berlin Information Center (BITS) for Transatlantic Security, June 1997, 10 April $2007<$ http://www.bits.de/public/ researchnote/rn97-3.htm>.

Bermudez, Joseph. Shield of the Great Leader: The Armed Forces of North Korea (Sydney: Allen and Urwin, 2001).

Bermudez, Joseph. The Armed Forces of North Korea (New York: I.B. Tauris, 2001).

Berry, Nicholas. "The Self-Serving 'Rogue State' Doctrine," Center for Defense Information, Washington, D.C., 2000, 14 Jan. $2007<$ www.cdi.org/asia/fa061600 .html>.

Bertalanffy, Ludwig. A Systems View of Man, ed. Paul A. LaViolette (Boulder: Westview Press, 1981).

Bertalanffy, Ludwig. General System Theory: Foundations, Development, Applications (New York: George Braziller, 1968).

Bertsch, Gary K., and Suzette R. Grillot, eds. Arms on the Market: Reducing the Risk of Proliferation in the Former Soviet Union, forward Sam Nunn (New York:

Routledge, 1998).

Betts, Richard K., ed. Conflict After the Cold War: Arguments on Causes of War \& Peace, $2^{\text {nd }}$ ed. (New York: Pearson, 2005).

Betts, Richard K. “Must War Find a Way?” International Security 24.2 (Fall 1999) 166198.

Betts, Richard K. "The Delusion of Impartial Intervention," Conflict After the Cold War. Arguments on Causes of War \& Peace, $2^{\text {nd }}$ ed., ed. Richard K. Betts (New York: Pearson Longman, 2005).

Betts, Richard K. "The New Threat of Mass Destruction," Foreign Affairs 77.1 (Jan/Feb 1998), 2 April $2008<$ http://www.ciaonet.org/casestudy/ber01/>.

Bianco, Mirella, and Muammar Qaddafi. Voice From the Desert (New York: Longman, 1975).

Bissell, Richard M., Jr., Jonathan E. Lewis, and Frances T. Pudlo. Reflections of a Cold Warrior: From Yalta to the Bay of Pigs (New Haven: Yale University Press, 1996). 
Black, Antony. The History of Islamic Political Thought: From the Prophet to the Present (New York: Routledge, 2001).

Blackstock, Paul W. The Strategy of Subversion: Manipulating the Politics of Other Nations (Chicago: Quadrangle, 1964).

Blainey, Geoffrey. "Power, Culprits, and Arms," Conflict After the Cold War: Arguments on Causes of War \& Peace, $2^{\text {nd }}$ ed., ed. Richard K. Betts (New York: Pearson-Longman, 2005).

Blainey, Geoffrey. The Causes of War, $3^{\text {rd }}$ ed. (New York: Free Press, 1988).

Blair, John M. The Control of Oil (New York: Pantheon, 1976).

Blasier, Cole. The Hovering Giant: US Responses to Revolutionary Change in Latin America 1910-1985, revised ed. (Pittsburgh: University of Pittsburgh Press, 1986).

Blight, James G., and Peter Kornbluh, eds. Politics of Illusion: The Bay of Pigs Invasion Reexamined (New York: Lynne Rienner, 1998).

Bloom, Howard K. The Lucifer Principle: A Scientific Expedition into the Forces of History (New York: Atlantic Monthly Press, 1995).

Blum, William. Freeing the World to Death: Essays on the American Empire (Monroe: Common Courage Press, 2005).

Blum, William. Rogue State: A Guide to the World's Only Superpower (Monroe: Common Courage Press 2000).

Blumberg, Daniel. "Khomeini's Legacy: Islamic Rule and Islamic Justice," Spokesman for the Despised: Fundamentalist Leaders of the Middle East, ed. R. Scott Appleby (Chicago: University of Chicago Press, 1997).

Blundy D., and A. Lycett. Qaddafi and the Libyan Revolution (London: Weidenfeld Nicolson, 1987).

Bohning, Don. The Castro Obsession: US Covert Operations in Cuba, 1959-1965 (Dulles: Potomac Books Inc., 2005).

Bonsal, Philip W. Cuba, Castro and the US (Pittsburgh: University of Pittsburgh Press, 1971)

Bosch, Olivia, and Peter van Ham, eds. Global Non-Proliferation and CounterTerrorism: The Impact of UNSCR 1540 (London: Chatham House, 2007). 
Boulding, Kenneth E. The Image (Ann Arbor: University of Michigan Press, 1961).

Bourdieu, Pierre. Science of Science \& Reflexitivity, trans. Richard Nice (Chicago: University of Chicago Press, 2004).

Brady, James. The Coldest War: A Memoir of Korea (New York: St. Martin's Press/Thomas Dunne Books, 1990).

Brasch, Walter M. America's Unpatriotic Acts: The Federal Government's Violation of Constitutional \& Civil Rights (New York: Peter Lang Publishing, 2005).

Bream, Erin. "Personalistic Political Leadership in Castro's Cuba," Claremont McKenna College Leadership Review, vol. 4 (Fall 2004), 16 May 2007 <www.leadershipre view.org/2004fall/article2_fall_2004.asp>.

Brewer, Sam Pope. "Castro Foes Call Cubans to Arms; Predict Uprising. US Aid Is Denied. Miro Insists an Attack on 'Tyrant' Can Start Without Invasion," New York Times, 9 April 1961, 22 May 2007 <http://www.latinamericanstudies.org/ bay-of-pigs/miro.htm>.

Brinton, Crane. The Anatomy of Revolution (New York: Random House, 1965).

British Broadcasting Corporation. "Alleged Cubana Bomber Ordered Freed," $B B C$ Caribbean News Online, 13 Sept. 2006, 4 June $2007<\mathrm{http} / /$ www.bbc.co.uk/ caribbean/ news/story/2006/09/060913_posada.shtml>.

British Broadcasting Corporation. "BBC Country Profile: Libya," BBC New Online, 24 Jan. 2007, 25 May $2007<\mathrm{http} / /$ news.bbc.co.uk/2/hi/africa/country_profiles/8192 91.stm \#facts>.

British Broadcasting Corporation. "Castro: Profile of the Great Survivor," BBC News Online, 2 Dec. 2006, 20 May $2007<$ http://news.bbc.co.uk/2/hi/americas/244974 .stm>.

British Broadcasting Corporation. "Congress Passes Anti-Terror Bill," BBC News Online, 28 July 2007, 5 August $2007<$ news.bbc.com.uk/2/hi/Americas/692019 8.stm>.

British Broadcasting Corporation. "Country Profile: Iran," BBC News Online, 26 May $2007<$ http://news.bbc.co.uk/2/hi/middle_east/country_profiles/790877.stm>.

British Broadcasting Corporation. "Georgia and US Foil Uranium Plot," BBC News Online, 25 Jan. 2007, 23 May $2007<$ http://news.bbc.co.uk/2/hi/europe/6297713 .stm>. 
British Broadcasting Corporation. "Pentagon Seeks $\$ 190$ bn War Funds," BBC News Online, 26 Sept. 2007, 27 Sept. $2007<$ http://news.bbc.co.uk/2/hi/americas/701 5087.stm>.

British Broadcasting Corporation. "Timeline: Libya, A Chronology of Key Events," BBC News Online, 26 April 2004, 26 May $2007<$ http://news.bbc.co.uk/2/hi/ middle_east/country_profiles/1398437.stm>.

British Broadcasting Corporation. "UN Checks North Korea, "Nuclear Halt," BBC News Online, 15 July 2007, 15 July 2007 <http://news.bbc.co.uk/2/hi/asia-pacific/6899 345.stm >.

Brodie, Bernard. "The Development of Nuclear Strategy," International Security 2.4 (Spring 1978) 65-83.

Brogan, Hugh. The Penguin History of the United States of America (London: Penguin Books, 1990).

Brookings Institution. Iraq Index: Tracking Reconstruction and Security in PostSaddam Iraq, 23 March 2008, 24 March $2008<$ http://www.brookings.edu/saban/ iraq-index.aspx>.

Brown, Michael E., et al., eds. Theories of War and Peace: An International Security Reader (Cambridge: Massachusetts Institute of Technology University Press, 2001).

Brown, Michael E., Sean Lynn-Jones, and Steven E. Miller, eds. The Perils of Anarchy: Contemporary Realism and International Security (Cambridge: Massachusetts Institute of Technology Press, 1995).

Brown, Seymon. The Causes \& Prevention of War (New York: St. Martin's Press, 1987).

Brzezinski, Zbigniew. The Grand Chessboard: American Primacy \& Geo-Strategic Imperatives (New York: Basic Books, 1997).

Buchta, Wilfried. The Structure of Power in the Islamic Republic (Washington, D.C.: Washington Institute for Near East Policy, 2000).

Bull, Hedley. The Anarchical Society: A Study of Order in World Politics, $2^{\text {nd }}$ ed., forward Stanley Hoffmann (New York: Columbia University Press, 1995).

Bulloch, John. The Making of a War: The Middle East: From 1967-1973 (London and New York: Longman, 1974). 
Bunck, Julie Marie. Fidel Castro and the Quest for a Revolutionary Culture in Cuba (University Park: Pennsylvania State University Press, 1994).

Bundy, McGeorge. "The Unimpressive Record of Atomic Diplomacy," The Use of Force: Military Power and International Politics, $6^{\text {th }}$ ed., eds. Robert J. Art and Kenneth N. Waltz (Lanham: Rowman, 2004).

Bunn, George, and Christopher F. Chyba, eds. US Nuclear Weapons Policy: Confronting Today's Threats, forward William J. Perry (Harrisonburg: R.R. Donnelley, 2006).

Burns, Gene. "Ideology, Culture, and Ambiguity: The Revolutionary Process in Iran," Theory and Society 25.3 (June 1996) 349-388.

Busch, Nathan E. No End in Sight: The Continuing Menace of Nuclear Proliferation (Lexington: University Press of Kentucky, 2004).

Bush, George H. New York Times, 29 Jan. 1992, A-16, 28 June 2007 <www.nytimes.co $\mathrm{m}>$.

Bush, George W. "President Bush Celebrates Independence Day With West Virginia Air National Guard 167th Airlift Wing, C-5 Maintenance Hangar, Martinsburg, West Virginia," The White House, Office of the Press Secretary, Washington, D.C., 4 July 2007, 5 July $2007<$ http://www.whitehouse.gov/news/releases/2007/07/2007 0704.html>.

Bush, George W. "President Signs USA PATRIOT Improvement and Reauthorization Act," The White House, East Room, 9 March 2006, 29 June 2007 <www.whiteh ouse.gov/news/releases/2006/03/20060309-4.html>.

Bush, George W. "Prevent Our Enemies From Threatening Us, Our Allies, and Our Friends with Weapons of Mass Destruction," The National Security Strategy of the United States of America 2002, Washington, D.C., The White House, 2002, 11 Nov. $2007<$ http://www.whitehouse.gov/nsc/nss5.html>.

Bush, George W. "State of the Union Address 2002," US Capitol, Washington D.C., 29 January 2002, The George W. Bush Foreign Policy Reader: Presidential Speeches With Commentary, ed. John W. Dietrich (New York: M.E. Sharpe, 2005).

Bush, George W. "Statement by the President in His Address to the Nation," The White House, Washington, D.C., 11 Sept. 2001, 14 June $2007<w w w . w h i t e h o u s e . g o v / n$ ews/releases/2001/09/20010911-16.html>. 
Bush, George W. Speech, The Citadel, Charleston, South Carolina, 11 Dec. 2001, The George W. Bush Foreign Policy Reader: Presidential Speeches With Commentary, ed. John W. Dietrich (New York: M.E. Sharpe, 2005).

Bush, George W. Speech, The Citadel, Charleston, South Carolina, 23 Sept. 1999, The George W. Bush Foreign Policy Reader: Presidential Speeches With Commentary, ed. John W. Dietrich (New York: M.E. Sharpe, 2005).

Bush, George W. Speech, The National Defense University, Washington, D.C., 1 May 2001, The George W. Bush Foreign Policy Reader: Presidential Speeches With Commentary, ed. John W. Dietrich (New York: M.E. Sharpe, 2005).

Bush, George W. Speech, The National Defense University, Washington, D.C., 11 Feb. 2004, The George W. Bush Foreign Policy Reader: Presidential Speeches With Commentary, ed. John W. Dietrich (New York: M.E. Sharpe, 2005).

Bush, George W. Speech, The National Press Club, Washington, D.C., 23 May 2000, The George W. Bush Foreign Policy Reader: Presidential Speeches With Commentary, ed. John W. Dietrich (New York: M.E. Sharpe, 2005).

Bush, George W. Speech, The Ronald Reagan Presidential Library, Simi Valley, California, 19 Nov. 1999, The George W. Bush Foreign Policy Reader: Presidential Speeches With Commentary, ed. John W. Dietrich (New York: M.E. Sharpe, 2005).

Bush, George W. Speech, The White House, Washington, D.C., 13 December 2001, The George W. Bush Foreign Policy Reader: Presidential Speeches With Commentary, ed. John W. Dietrich (New York: M.E. Sharpe, 2005).

Bush, George W. Speech, UN General Assembly, New York, NY, 10 Nov. 2001, The George W. Bush Foreign Policy Reader: Presidential Speeches With Commentary, ed. John W. Dietrich (New York: M.E. Sharpe, 2005).

Bush, George W. Speech, US Capitol, Washington, D.C., 20 Sept. 2001, The George $W$. Bush Foreign Policy Reader: Presidential Speeches With Commentary, ed. John W. Dietrich (New York: M.E. Sharpe, 2005).

Bush, George W. Speech, US Military Academy, West Point, New York, 1 June 2002, The George W. Bush Foreign Policy Reader: Presidential Speeches With Commentary, ed. John W. Dietrich (New York: M.E. Sharpe, 2005).

Bush, George W. Speech, Warsaw Royal Castle, Krakow, Poland, 31 May 2003, The George W. Bush Foreign Policy Reader: Presidential Speeches With Commentary, ed. John W. Dietrich (New York: M.E. Sharpe, 2005). 
Bush, George W. Speech, Whitehall Palace, London, England, 19 Nov. 2003, The George W. Bush Foreign Policy Reader: Presidential Speeches With Commentary, ed. John W. Dietrich (New York: M.E. Sharpe, 2005).

Bush, George W. The National Security Strategy of the US, 12 July $2007<$ www.white house.gov/nsc/nssall.html>.

Butt, Gerald. “Colonel Gaddafi's Libya," BBC News Online, 15 May 2006, 21 May $2007<\mathrm{http}: / /$ news.bbc.co.uk/2/hi/middle_east $/ 3336059 . \mathrm{stm}>$.

Buzan, Barry, and Ole Wæver. Regions and Powers: The Structure of International Security (Cambridge: Cambridge University Press, 2003).

Buzo, Adrian. The Guerilla Dynasty: Politics \& Leadership in North Korea (Boulder: Westview, 1999).

Buzo, Adrian. The Making of Modern Korea: A History (London/New York: Routledge, 2002).

Campbell, David. Writing Security: United States Foreign Policy and the Politics of Identity (Minneapolis: University of Minnesota Press, 1998).

Cameron, Fraser. US Foreign Policy After the Cold War: Global Hegemon or Reluctant Sheriff? $2^{\text {nd }}$ ed. (London: Routledge, 2005).

Capan, Ergun, ed. Terror and Suicide Attacks: An Islamic Perspective (Somerset: The Light Inc., 2004).

Caprioli, Mary, and Peter F. Trumbore. "Identifying 'Rogue' States and Testing their Interstate Conflict Behavior," European Journal of International Relations 9.3 (2003) 377-406.

Caprioli, Mary, and Peter F. Trumbore. "Rhetoric Versus Reality: Rogue States in Interstate Conflict," Journal of Conflict Resolution 49.5 (2005) 770-791.

Carpenter, Ted G., and Doug Bandow. The Korean Conundrum: America's Troubled Relations With North and South Korea (New York: Palgrave, 2004).

Carr, E. H. "Realism and Idealism," Conflict After the Cold War: Arguments on Causes of War and Peace, $2^{\text {nd }}$ ed., ed. Richard K. Betts (New York: Pearson, 2005).

Carr, E. H. The Twenty Years' Crises, 1919-1939: An Introduction to the Study of International Relations (New York: Harper and Row, 1964). 
Carter, Ashton B. "Alternatives to Letting North Korea Go Nuclear," Testimony Before the Committee on Foreign Relations, US Senate, 6 March 2003, 20 July 2007 $<$ www.cfr.org $>$.

Carter, John J. Covert Action As a Tool of Presidential Foreign Policy: From the Bay of Pigs to Iran-Contra (Lewiston: Edwin Mellen Press, 2006).

Cassidy, Mike, and Will Miller. A Short History of FBI COINTELPRO, 28 June 2007 $<\mathrm{http}: / / \mathrm{www}$.monitor.net/monitor/9905a/jbcointelpro.html>.

Castro, Fidel, and Jose Ramon Fernandez. Playa Giron: Bay of Pigs. Washington's First Military Defeat in the Americas, eds. Steve Clark and Mary Alice Waters (New York: Pathfinder Press, 2001).

Castro, Fidel. Capitalism in Crisis: Globalization \& World Politics Today, ed. David Deutschmann (Melbourne/New York: Ocean Press, 2000).

Castro, Fidel. Fidel Castro on the Bay of Pigs (Hoboken: Ocean Press, 2004).

Castro, Fidel. The Declarations of Havana, ed. Tariq Ali (New York and London: Verso, 2007).

Center For Non-Proliferation Studies. WMD Country Profiles Database, 17 August 2007 $<$ http://cns.miis.edu/dbinfo/about.htm $>$.

Cha, Victor D., and David C. Kang. Nuclear North Korea: A Debate on Engagement Strategies (New York: Columbia University Press, 2003).

Chambou, Raafat. The Power and Concept of the Libyan Revolution (Lausanne: Editions Méditerranéennes, 1977).

Chang, Nancy. Silencing Political Dissent, forward Howard Zinn (New York: Seven Stories, 2002).

Chappel, Timothy. "Plato on Knowledge in the Theaetetus," Stanford Encyclopedia of Philosophy, 7 May 2005, 27 Dec. $2007<$ http://plato.stanford.edu/entries/platotheaetetus /\#9>.

Cheang-ha, Kim. The Immortal Juche Idea (Pyongyang: Foreign Languages Publishing House, 1984).

Cheney, Dick. Speech, Council on Foreign Relations, 15 Feb. 2002, New York Times, 16 February 2002, A-6. 
Chol, Kim Myong. "Kim Jong-Il's Military-First Policy a Silver Bullet," Asia Times, 4 Jan 2007, 5 April $2007<$ www.atimes.com/atimes/Korea/IA04Dg01.html>.

Chol, Ryo Sung. Korea: The 38th Parallel North (Honolulu: University of the Pacific Press, 2004).

Chomsky, Noam, and Michel Foucault. The Chomsky-Foucault Debate On Human Nature, forward John Rajchman (New York: New Press, 2006).

Chomsky, Noam, Ramsey Clark, and Edward W. Said. Acts of Aggression: Policing Rogue States (New York: Seven Stories Press, 1999).

Chomsky, Noam. Rogue States: The Rule of Force in World Affairs (Cambridge: South End Press, 2000).

Christopher, Warren. "America's Strategy for a Peaceful and Prosperous Asia-Pacific," US Department of State Dispatch, vol. 6, 591-544, Washington D.C., 31 July 1995, 10 April $2008<$ http://findarticles.com/p/articles/mi_m1584/is_n31_v6/ai_ 17259729>.

Chubin, Shahram. Iran's National Security Policy: Intentions, Capabilities \& Impact (Washington D.C.: Carnegie Endowment, 1994).

Cimbala, Stephen J., ed. Deterrence and Nuclear Proliferation in the Twenty-First Century (Westport: Praeger, 2001).

Claude, Inis. Power \& International Relations (New York: Random House, 1962).

Clausewitz, Carl M. Von. On War, ed. and intro. Anatol Rapoport (New York: Penguin Books, 1982).

Clinton, Hillary. "Transcript: The Democrats' Second 2008 Presidential Debate," New York Times Online, 3 June 2007, 4 June $2007<$ http://www.nytimes.com/2007/06 /03/us/politics/03demsdebate_transcript.html $>$.

Clinton, William Jefferson. "Strengthening American Security Through World Leadership," US Department of State Dispatch, vol. 6, 53, Washington, D.C., 30 January 1995.

CNN.com/Inside Politics. "Bush: Iraq is One Victory in War on Terror," CNN.com/ Inside Politics, 2 May 2003, 13 Jan. 2007 <http://www.cnn.com/2003/ALLPOLI TICS /05/01/sprj.irq.bush.speech/index.html $>$.

Cohen, Adam. "Two Things Linger in Cuba: Fidel and a Pointless Embargo," New York Times [Late Edition] 12 Jan. 2003, 4.14. 
Cohen, Eliot A. "A Revolution in Warfare," Foreign Affairs 75.2 (March/April 1996).

Cole, David, and James Dempsey. Terrorism \& the Constitution: Sacrificing Civil Liberties in the Name of National Security, $2^{\text {nd }}$ ed. (New York: W. W. Norton, 2002).

Coltman, Leycester. The Real Fidel Castro (New Haven: Yale University Press, 2003).

Cooley, John K. Libyan Sandstorm (New York: Holt, Rinehart \& Winston, 1982).

Cordes, Bonnie. Qaddafi: Idealist and Revolutionary Philanthropist (Santa Monica:

RAND Corporation, 1986), 28 May $2007<\mathrm{http} / /$ www.rand.org/pubs/papers/P72 $09 />$.

Cox, Robert W. Production, Power, and the World Order (New York: Columbia University Press, 1987).

Craig-Harris, Lillian. Libya: Qadhafi's Revolution and the Modern State (Boulder: Westview Press, 1986).

Crampton, R. J. The Hollou Détente: Anglo-German Relations in the Balkans 19111914 (Atlantic Highlands: Humanities Press, 1980).

Crawford, Natalie W., and Chung-in Moon, eds. Emerging Threats, Force Structures, and the Role of Air Power in Korea (Santa Monica: RAND Corporation, 2000).

Crenshaw, Martha. Terrorism \& International Cooperation (New York: Institute for East-West Studies, 1989).

Crenshaw, Martha. Terrorism in Context (University Park: Pennsylvania State University Press, 1995).

Crosston, Matthew. Fostering Fundamentalism: Terrorism, Democracy and American Engagement in Central Asia: US Foreign Policy and Conflict in the Islamic World (Burlington: Ashgate Publishing, 2006).

Crothers, Lane, and Charles Lockhart, eds. Culture \& Politics: A Reader (New York: St. Martin's Press, 2000).

Cumings, Bruce. Divided Korea: United Future (Ithaca: Foreign Policy Association, 1995).

Cumings, Bruce. Korea's Place in the Sun: A Modern History (New York: W.W. Norton, 2005). 
Cumings, Bruce. North Korea: Another Country (New York: New Press, 2003).

Cumings, Bruce. Parallax Visions: Making Sense of American-East Asian Relations at the End of the Century (Durham: Duke University Press, 1999).

Cummings, Bruce, Ervand Abrahamian, and Moshe Ma'oz, eds. Inventing the Axis of Evil: The Truth About North Korea, Iran, and Syria (New York: New Press, 2004).

Daalder, Ivo H., and Terry Terriff, eds. Rethinking the Unthinkable: New Directions for Nuclear Arms Control (Portland: Frank Cass Co., 1993).

Dabashi, Hamid. Theology of Discontent: The Ideological Foundation of the Islamic Revolution in Iran (New Brunswick: Transaction Publishers, 2006).

Daley, Suzanne. "French Minister Calls US Policy Simplistic," New York Times, 7 February 2002, A-10.

Daniel, Elton L. The History of Iran (Westport: Greenwood Press, 2000).

Darmer, M. Katherine, Robert M. Baird, and Stuart E. Rosenbaum, eds. Civil Liberties vs. National Security in a Post 9/11 World (Amherst: Prometheus Books, 2004).

Darrell-Bender, Lynn. Cuba Versus the US: The Politics of Hostility, $2^{\text {nd }}$ ed. (San Juan: Inter-American University Press, 1981).

Dateline/SBS World News. "Interview with Yahya Mahmassani, Arab League Ambassador to the United Nations," 8 October 2003, Dateline/SBS World News, 2 Aug. $2007<$ http://news.sbs.com.au/dateline/index.php?page $=$ archive $\&$ daysum $=2$ 003-10-08\#>.

David, Charles Philippe, and David Grondin, eds. Hegemony or Empire? The Redefinition of US Power Under George W. Bush (Burlington: Ashgate Publishing Company, 2006).

Davis, Brian L. Qaddafi, Terrorism \& the US Attack on Libya (New York: Praeger, 1990).

Davis, John. Libyan Politics: Tribe \& Revolution (Berkeley and Los Angeles: University of California Press, 1988).

De Candole, E. A. V. The Life and Times of King Indris of Libya (Manchester: Ben Ghalbon, 1990). 
Debord, Guy. The Society of the Spectacle, trans. Donald Nicholson-Smith (New York: Zone Books, 1995).

Deeb, Marius K., and Mary Jane Deeb. Libya Since the Revolution: Aspects of Social and Political Development (New York: Praeger, 1982).

Defronzo, James. Revolutions And Revolutionary Movements, $3^{\text {rd }}$ ed. (Cambridge/ New York: Westview Press, 2007).

Deleuze, Gilles, and Felix Guattari. Anti-Oedipus: Capitalism and Schizophrenia, trans. Robert Hurley, Mark Seem, and Helen R. Lane, preface Michel Foucault (Minneapolis: University of Minnesota Press, 2003).

Deleuze, Gilles, and Felix Guattari. "Kafka: Toward a Minor Literature," trans. Dana Polan, The Norton Anthology of Theory and Criticism, eds. Vincent B. Leitch, William E. Cain, Laurie A. Fink, Barbara E. Johnson, John McGowan, and Jeffery J. Williams (New York: W.W. Norton, 2001).

Deleuze, Gilles, and Felix Guattari. What is Philosophy? eds. and trans. Hugh Tomlinson, Janis Tomlinson, and Graham Burchell (New York: Columbia University Press, 1994).

Democratic People's Republic of Korea. "Study of the Juche Idea," International Institute of the Juche Idea, Journal of the IIJI no. 78 (English Edition), December 2006, 13 June 2007 <www.cnet-ta.ne.jp/juche/DEFAULTE.htm>.

Democratic People's Republic of Korea. Kim Il Sung: Short Biography, vol. 2 (Pyongyang: Foreign Languages Publishing House, 1973).

Democratic People's Republic of Korea. Socialist Constitution of the Democratic People's Republic of Korea (Pyongyang: Foreign Language Publishing House, 1998).

Derrida, Jacques. "Dissemination: Plato's Pharmacy," trans. Barbara Johnson, The Norton Anthology of Theory and Criticism, eds. Vincent B. Leitch, William E. Cain, Laurie A. Fink, Barbara E. Johnson, John McGowan, and Jeffery J. Williams (New York: W.W. Norton, 2001).

Derrida, Jacques. "Speech and Phenomena," A Derrida Reader: Between the Blinds, trans. David B. Allison, intro. and ed. Peggy Kamuf (New York: Columbia University Press, 1991).

Dessler, David. "What is at Stake in the Agent-Structure Debate?" International Organization 43.3 (1989) 441-474. 
Dietrich, John W., ed. The George W. Bush Foreign Policy Reader: Presidential Speeches With Commentary (New York: M.E. Sharpe, 2005).

Dolgoff, Sam. The Cuban Revolution: A Critical Perspective (Toronto: Black Rose Books, 1996), 15 Oct. $2007<\mathrm{http} / / /$ dwardmac.pitzer.edu/Anarchist_Archives/ bright/dolgoff/cubanrevolution/toc.html $>$.

Doran, Charles. "Power Cycle Theory of Systems, Structure \& Stability: Commonalities \& Complementarities," Handbook of War Studies, ed. Manus Midlarsky (Boston: Unwin-Hyman, 1989).

Doran, Charles. "The Globalist-Realist Debate," Intervention Into the 1990s: US Foreign Policy in the Third World, ed. Peter J. Schraeder (Boulder: Lynne Rienner, 1992).

Downs, Chuck. Over the Line: North Korea's Negotiating Strategy, forward James R. Lilley (Washington, D.C.: American Enterprise Institute, 1999).

Drake, Laura. US-Libyan Relations: Which Path to the Future? (Springfield: UASR Publishing Group, 2001).

Draper, Theodore. Castro's Revolution: Myths \& Realties (New York: Thomas \& Hudson, 1962).

Duong, Thanh. Hegemonic Globalization: US Centrality \& Global Strategy in the Emerging World Order (Burlington: Ashgate Publishing, 2002).

Easton, David. The Political System: An Inquiry into the State of Political Science (New York: Alfred A. Knopf, 1953).

Eberstadt, Nicholas, and Judith Bannister. The Population of North Korea (Berkeley: Institute of East Asian Studies/University of California Press, 1992).

Eberstadt, Nicholas. "Tear Down This Tyranny," Weekly Standard 10.11, 29 Nov. 2004, 11 April $2008<\mathrm{http}: / / \mathrm{www}$.weeklystandard.com/Content/Public/Articles/000/00 0/004/951szxxd.asp>.

Eberstadt, Nicholas. "What Surprise? The Nuclear Core of North Korea's Strategy," Washington Post, 1 March 2005.

Eckert, Carter J., Ki-baik Lee, Young Ick Lew, Michael Robinson, and Edward W. Wagner. Korea Old \& New: A History (Cambridge: Korea Institute/Harvard University Press, 1990). 
Einstein, Albert. Ideas \& Opinions, ed., Carl Seelig, trans. Sonja Bargmann, intro. Alan Lightman (New York: Random House, 1994).

Elhadj, Elie. The Islamic Shield: Arab Resistance to Democratic and Religious Reforms (Boca Raton: Brown Walker Press, 2006).

El-Kikhia, Mansour O. Libya's Qaddafi: The Politics of Contradiction (Gainesville: University Press of Florida, 1998).

Ellis, Jason D., and Geoffrey D. Kiefer. Combating Proliferation: Strategic Intelligence and Security Policy (Baltimore: Johns Hopkins University Press, 2004).

Encyclopedia Britannica. "Biography of Ruhollah Khomeini," The Encyclopedia Britannica Online, 5 April $2007<\mathrm{http} / /$ www.britannica.com/eb/article-9045329/ Ruhollah-Khomeini>.

Erik, Cornell. North Korea Under Communism: Report of an Envoy to Paradise (New York: Routledge-Curzon, 2002).

Escobar, Arturo. Encountering Development: The Making and Unmaking of the Third World (Princeton: Princeton University Press, 1994).

Esposito, John L., ed. The Iranian Revolution: Its Global Impact (Miami: Florida International University Press, 1990).

Etzioni, Amitai. How Patriotic is the Patriot Act? Freedom Versus Security in the Age of Terrorism (New York/London: Routledge, 2007).

Evans, Graham, and Jeffrey Newnham. The Dictionary of World Politics (London: Harvester Wheatsheaf, 1992).

Evans, Peter. "Predatory Developmental, and Other Apparatuses: A Comparative Political Economy Perspective on the Third World State," Sociological Forum 4.4 (1989) 561-587

Evans, Peter. Dependent Development: The Alliance of Multinational, State \& Local Capital in Brazil (Princeton: Princeton University Press, 1979).

Fairbanks, Charles H., Jr., and Abram N. Shulsky. "From 'Arms Control' to Arms Reductions: The Historical Experience," The Washington Quarterly 10.3 (Summer 1987) 59-73.

Falk, Pamela S. "The US-Cuba Agenda: Opportunity or Stalemate," Journal of InterAmerican Studies and World Affairs 39.1, Special Issue: US-Latin American Relations (Spring 1997) 153-162. 
Farah, Mounir A. World History: The Human Experience, $7^{\text {th }}$ ed. (New York: Glencoe/ McGraw-Hill, 2001).

Farsoun, Samih K., and Mehrdad Mashayekhi, eds. Iran: Political Culture in the Islamic Republic (London: Routledge, 1992).

Fate-Norton, David. The Cambridge Companion to Hume (New York: Cambridge University Press, 1993).

Feffer, John, ed. Power Trip (New York: Seven Stories Press, 2003).

Feffer, John. North Korea/South Korea: US Policy at a Time of Crisis (New York: Seven Stories, 2003).

Feffer, John. The Future of US-Korean Relations: The Imbalance of Power (New York: Routledge, 2006).

Fehrenbach, T. R. This Kind of War: The Classic Korean War History - Fiftieth Anniversary Edition (Dulles: Potomac Books Inc., 2001).

Feldman, Ofer, and Linda O. Valenty. Profiling Political Leaders: Cross-Cultural Studies of Personality and Behavior (Westport: Praeger, 2001).

Finan, Christopher. From the Palmer Raids to the Patriot Act: A History of the Fight for Free Speech in America (Boston: Beacon Press, 2007).

Financial Action Task Force. Financial Action Task Force Home Page, 17 March 2008 $<$ http://www.fatfgafi.org/pages/0,2987,en_32250379_32235720_1_1_1_1_1,00.ht $\mathrm{ml}>$.

Find-Law Legal News \& Commentary. "KOREAN WAR ARMISTICE AGREEMENT, 27 July 1953," Find-Law Legal News \& Commentary, 26 May $2007<$ http://news. findlaw.com/hdocs/docs/korea/kwarmagr 0727 53.html $>$.

Finnemore, Martha. "Constructing Norms of Humanitarian Intervention," Conflict After the Cold War: Arguments on Causes of War \& Peace, $2^{\text {nd }}$ ed., ed. Richard K. Betts (New York: Pearson-Longman, 2005).

First, Ruth. Libya: The Elusive Revolution (New York: Penguin Books, 1974).

Fischer, Michael M. J. Iran: From Religious Dispute to Revolution (Cambridge: Harvard University Press, 1980).

Fischer, Thekla. "The Currency of Coercion: For Washington and Tehran" (MA thesis, University of Michigan, Ann Arbor, 1996). 
Flint, Charles A. "Challenging the Legality of Section 106 of the USA PATRIOT Act," 67 Alb. L. Rev. 1138, Albany Law Review (2004).

Ford, Henry. "Mass Production," Seven Famous Reprints From the New Britannica, $13^{\text {th }}$ ed. (London: Britannica, 1926).

Foster, John Bellamy. Naked Imperialism: The U.S. Pursuit of Global Dominance (New York: Monthly Review Press, 2006).

Foster-Carter, Aidan. "Analysis: North Korea's Move," BBC News Online, 16 April 2003, 15 August $2007<w w w . b b c . c o m>$.

Foucault, Michel. The Archaeology of Knowledge \& the Discourse on Language, trans. Rupert Swyer (New York: Pantheon, 1972).

Foucault, Michel. "Discipline and Punish: The Birth of the Prison," trans. Alan Sheridan, The Norton Anthology of Theory and Criticism, eds. Vincent B. Leitch, William E. Cain, Laurie A. Fink, Barbara E. Johnson, John McGowan, and Jeffery J. Williams (New York: W.W. Norton, 2001).

Foucault, Michel. "What is an Author?" The Norton Anthology of Theory and Criticism, eds. Vincent B. Leitch, William E. Cain, Laurie A. Fink, Barbara E. Johnson, John McGowan, and Jeffery J. Williams (New York: W.W. Norton, 2001).

Foucault, Michel. Politics, Philosophy \& Culture: Interviews \& Other Writings 1977. 1984, trans. Alan Sheridan, ed. and intro. Lawrence D. Kritzman (New York and London: Routledge, 1988).

Foucault, Michel. Power/Knowledge: Selected Interviews and Other Writings, 19721977, ed. and trans. Colin Gordon (New York: Pantheon, 1980).

Foucault, Michel. Power: Essential Works of Foucault, 1954-1984, Vol. III, trans. Robert Hurley, intro. Colin Gordon, ed. James D. Faubion (New York: New Press, 1994).

Foucault, Michel. Society Must Be Defended: Lectures at the College de France, 1975 1976, trans David Macy, intro. Arnold I. Davidson, ed. and forward François Ewald, Alessandro Fontana, and Mauro Bertani (New York: Picador, 2003).

Freedman, Lawrence. The Evolution of Nuclear Strategy, $3^{\text {rd }}$ ed. (New York: Palgrave, 2003).

Freeman, Chas W., Jr. Arts of Power: Statecraft \& Diplomacy (Washington, D.C.: United States Institute of Peace, 1997). 
Frieden, Jeffery R. "Third World Indebted Industrialization: International Finance and State Capitalism in Mexico, Brazil, Algeria, and South Korea," International Organization 35.30 (1981) 407-431.

Frieden, Jeffery R., and David R. Lake. International Political Economy, $4^{\text {th }}$ ed. (New York: Routledge, 1999).

Frieman, Wendy. China, International Arms Control and Non-Proliferation (New York/ London: Routledge-Curzon, 2004).

Fujimoto, Masashi. "Capability Analysis of North Korean Special Forces," 8 March $2007<$ www.drc-jpn.org/AR-6E/fujimoto-e02.htm>.

Fukuyama, Francis. "The End of History?" The National Interest 16 (Summer 1989), 14 April $2008<$ http://www.wesjones.com/eoh.htm\#source>.

Fuller, Graham. Islamic Fundamentalism in Afghanistan: Its Character \& Prospects (Santa Monica: RAND Corporation, 1991), 31 May $2007<$ http://www.rand.org/ pubs/authors/f/fuller_graham.html $>$.

Fuller, Graham. Islamic Fundamentalism in Pakistan: Its Character \& Prospects (Santa Monica: RAND Corporation, 1991), 31 May $2007<\mathrm{http} / /$ www.rand.org/pubs/ authors/f/ fuller_graham.html>.

Gabriel, Mark A. Islam and Terrorism: What the Quran Really Teaches About Christianity, Violence, and the Goals of the Islamic Jihad (Lake Mary: Charisma House, 2002).

Gabriel, Satya J. "Class Analysis of the Iranian Revolution of 1979," Re/presenting Class, eds. Gibson-Graham, Resnick, and Wolff (Durham: Duke University Press, 2001), available online at Mount Holyoke College, Department of Economics, 27 May $2007<\mathrm{http}: / /$ www.mtholyoke.edu/courses/sgabriel/iran. htm.>

Gaddis, John L. "Implementing Flexible Response: Vietnam as a Test Case," The Use of Force: Military Power and International Politics, $6^{\text {th }}$ ed., eds. Robert J. Art and Kenneth N. Waltz (Lanham: Rowman, 2004).

Gaddis, John L. "The Long Peace: Elements of Stability in the Post-War International System," INR 6338 Strategic Studies Reader, Florida International University, Miami, FL (Fall 2005) 223.

Gaddis, John L. The Long Peace: Inquiries Into the History of the Cold War (New York: Oxford University Press, 1989). 
Gaddis, John Lewis. "A Grand Strategy of Transformation," Foreign Policy 133 (Nov/Dec 2002) 50-57.

Gallagher, Charles F. The United States and North Africa (Cambridge: Harvard University Press, 1962).

Gardner, Lloyd C., and Marilyn B. Young, eds. The New American Empire: A 21st Century Teach-in on US Foreign Policy (New York: New Press, 2005).

Gellner, Ernest. "Nations and Nationalism," Conflict After the Cold War: Arguments on Causes of War and Peace $2^{\text {nd }}$ ed., ed. Richard K. Betts (New York: PearsonLongman, 2005).

George, Alexander L. "Case Studies and Theory Development," Diplomacy: New Approaches in History, Theory, and Policy, ed. Paul Gordon Lauren (New York: Free Press, 1979).

Gereffi, G. "Rethinking Development Theory: Insights From the East Asia and Latin America," Sociological Forum 4.4 (1989) 505-533.

Gershman, John. "Is Southeast Asia the Second Front?" Foreign Affairs 81.4 (2002) 6074.

Gill, Stephen. Power \& Resistance in the New World Order (New York: Palgrave, 2003).

Gilpin, Robert. The Political Economy of International Relations (Princeton: Princeton University Press, 1987).

Gilpin, Robert. War \& Change in World Politics (Cambridge: Cambridge University Press, 1981).

Glaser, Charles L., and Steve Fetter. "National Missile Defense \& the Future of US Nuclear Weapons Policy," INR 6338 Strategic Studies Reader, Florida International University, Miami, FL (Fall 2005) 12-13.

Global Policy Forum. "Educational Module on Chemical \& Biological Weapons (Non-) Proliferation," CBW Educational Non-Proliferation Module, Case Study: Libya, 22 May $2007<$ http://www.globalpolicy.org/security/sanction/libya/indxirlb.htm \#sanction>.

Global Policy Forum. Global Policy Forum: Libya, 21 May $2007<$ http://www.global policy.org/security/sanction/libya/indxirlb.htm\#documents>. 
Global Security On-line. "United States Air Forces in Europe - Munitions Support Squadron," Global Security Online, 11 April $2007<$ http://www.globalsecurity .org/wmd/agency/usafe-munss.htm>.

Globalsecurity.org. "Revolutionary View of the Leader," Globalsecurity.org, 13 June $2007<$ www.globalsecurity.org/military/world/dprk/suryong.htm>.

Goldstein, Judith, and Robert O. Keohane. Ideas and Foreign Policy (Ithaca: Cornell University Press, 1993).

Goldstone, Jack A. The Encyclopedia of Political Revolutions (Chicago: Fitzroy Dearborn, 1998).

Gonzalez, David. "Dissident Accuses Cuba of Manipulating Fear of US Invasion," New York Times, 20 May 2003, A-5.

Gonzalez, Edward. Cuba Under Castro: The Limits of Charisma (Boston: Houghton Mifflin Company, 1974).

Gordon, Colin. Afterword, Power/Knowledge: Selected Interviews \& Other Writings 1972-1977, by Michel Foucault, ed. and trans. Colin Gordon (New York:

Pantheon, 1980).

Gosfield, Frank. Korea: Land of the 38th Parallel (New York: Macmillan, 1969).

Gourevitch, Peter. Politics in Hard Times: Comparative Responses to International Economic Crises (Ithaca: Cornell University Press, 1986).

Gray, Colin S. The Sheriff: America's Defense of the New World Order (Lexington: University of Kentucky Press, 2004).

Gray, Richard B., ed. International Security Systems: Concepts \& Models of World Order (Ithaca: F.E. Peacock, 1969).

Green, Jerrold D. Revolution in Iran: The Politics of Counter-Mobilization (Westport: Praeger, 1982).

Grinker, Roy R. Korea and Its Futures (New York: St. Martin's Press, 1998).

Gross, Leo. "The Peace of Westphalia," The American Journal of International Law 42.1 (Jan. 1948) 20-41.

Grotius, Hugo. "Prolegomena to the Law of War \& Peace," Classics of International Relations, ed. John A. Vasquez (Englewood Cliffs: Prentice Hall, 1986). 
Gunaratna, Rohan. Inside Al Qaeda: Global Network of Terror (New York: Columbia University Press, 2002).

Gurtov, Mel. "American Crusades: Unilateralism, Past \& Present," Confronting the Bush Doctrine: Critical Views From the Asia-Pacific, eds. Mel Gurtov and Peter Van Ness (London: Routledge-Cruzon, 2005).

Guzzini, Stefano. Realism in International Relations and International Political Economy: The Continuing Story of a Death Foretold (London/New York: Routledge, 1998).

Haley, P. Edward. Qaddafi \& the US Since 1969 (New York: Praeger, 1984).

Halliday, Fred, and Justin Rosenberg. "Interview With Kenneth Waltz," Review of International Studies 24.3 (1998) 371-386.

Hamel-Green, Michael. Regional Initiatives on Nuclear and WMD-Free Zones: Cooperative Approaches to Arms Control and Non-Proliferation, forward Patricia Lewis (Geneva: United Nations Institute for Disarmament Research, 2005).

Hamm, Taik-Young. Arming the Two Koreas: State, Capital and Military Power (New York: Routledge, 1999).

Hardt, Michael, and Antonio Negri. Empire (Cambridge: Harvard University Press, 2000).

Hardt, Michael, and Antonio Negri. Multitude: War \& Democracy in the Age of Empire (New York: Penguin, 2004).

Harries, Owen. "Australia \& the Bush Doctrine: Punching Above Our Weight?" Confronting the Bush Doctrine: Critical Views From the Asia-Pacific, eds. Mel Gurtov and Peter Van Ness (London: Routledge-Curzon, 2005).

Harris, David. The Crisis: The President, the Prophet, and the Shah - 1979 and the Coming of Militant Islam (New York: Little, Brown and Co., 2000).

Harris, L. C. Libya: Qaddafi's Revolution \& the Modern State (Boulder: Westview Press, 1986).

Harrison, Selig S. "The Missiles of North Korea," World Policy Journal 17 (Fall 2000) 13-24.

Harry S. Truman Presidential Museum and Library. Harry S. Truman Presidential

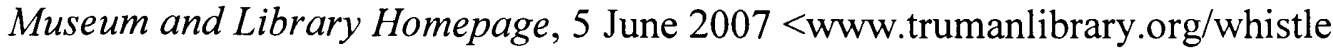
stop/study_collections/doctrine/large/index.php $>$. 
Hart, Parker T. Saudi Arabia \& the United States: Birth of a Security Partnership (Bloomington: Indiana University Press, 1998).

Hastings, Max. The Korean War (New York: Touchstone Books, 1987).

Heidegger, Martin. "Language," trans. Albert Hofstader, The Norton Anthology of Theory and Criticism, eds. Vincent B. Leitch, William E. Cain, Laurie A. Fink, Barbara E. Johnson, John McGowan, and Jeffery J. Williams (New York: W.W. Norton, 2001).

Heikal, Mohamed. The Return of the Ayatollah: The Iranian Revolution From Mossadeq to Khomeini (London: Andre Deutsch, 1981).

Hendrickson, David C. "Toward Universal Empire: The Dangerous Quest for Absolute Security," World Policy Journal 19.3 (Fall 2002) 1-3, 12 April $2008<$ http://www .worldpolicy.org/journal/articles/wpj02-3/hendrickson.html>.

Henriksen, Thomas H. "The Rise and Decline of Rogue States," Journal of International Affairs 54.2 (Spring 2001) 349-373.

Herb, Michael. All in the Family: Absolutism, Revolution, and Democratic Prospects in the Middle Eastern Monarchies (Albany: State University of New York Press, 1999).

Herrnstein-Smith, Barbara. "Contingencies of Value," The Norton Anthology of Theory and Criticism, eds. Vincent B. Leitch, William E. Cain, Laurie A. Fink, Barbara E. Johnson, John McGowan, and Jeffery J. Williams (New York: W.W. Norton, 2001).

Higgins, Trumball. The Perfect Failure: Kennedy, Eisenhower, the CIA, and the Bay of Pigs (New York: Norton, 1987).

Hiro, Dilip. Holy Wars: The Rise of Islamic Fundamentalism (New York: Routledge, 1989).

Hoare, James E., and Susan Pares. North Korea in the 21st Century: An Interpretative Guide (Kent: Global Oriental, 2005).

Hobsbawm, Eric. The Age of Extremes: A History of the World, 1914-1991 (New York: Vintage, 1996).

Hobson, J. A. Imperialism: A Study (New York: Cosimo Press, 2005). 
Hodge, Homer T. "North Korea's Military Strategy," Parameters, US Army War College (Spring 2003) 68-81, 16 Feb. 2007 <http://www.carlisle.army.mil/usawc/Parame ters/03spring/hodge.htm>.

Hoge, James F., Jr., and Gideon Rose, eds. How Did This Happen: Terrorism and the New War (New York: Public Affairs, 2001).

Hollis, Martin, and Steve Smith. Explaining \& Understanding International Relations (New York: Oxford University Press, 1990).

Holsti, Ole R. "Models of International Relations \& Foreign Policy," American Foreign Policy: Theoretical Essays, $3^{\text {rd }}$ ed., ed. G. John Ikenberry (New York: Longman, 1999).

Holsti, Ole R., Robert C. North, and Richard Brody, "Perception and Action in the 1914 Crisis," Quantitative International Politics, ed. J. David Singer (New York: Free Press, 1968).

Hong, Jung-Wook. "Ultimate US Goal is North Korea Regime Change," Korea Herald, 24 Feb. 2005.

Hoveyda, Fereydoun. The Shah and the Ayatollah: Iranian Mythology and Islamic Revolution (Westport: Praeger, 2003).

Hudson, Michael. Super Imperialism: The Origin and Fundamentals of US World Dominance, $2^{\text {nd }}$ ed. (London: Pluto Press, 2003).

Hume, David. An Enquiry Concerning Human Understanding, ed. Tom L. Beauchamp (New York: Oxford University Press, 2006).

Hunt, Howard. "Interview with Howard Hunt, Former CIA Operative, Central America," CNN Perspectives Series: The Bay of Pigs and the Cold War, 23 May 2007 $<$ http://ww w.cnn.com/SPECIALS/cold.war/episodes/18/interviews/hunt/>.

Hunter, Helen Louise. Kim Il Sung's North Korea (Westport: Praeger, 1999).

Huntington, Samuel P. "Arms Races: Prerequisites \& Results," Conflict After the Cold War: Arguments on Causes of War \& Peace, $2^{\text {nd }}$ ed., ed. Richard K. Betts (New York: Pearson-Longman, 2002).

Huntington, Samuel P. "The Clash of Civilizations," Foreign Affairs 72.3 (Summer 1993).

Huntington, Samuel P. The Clash of Civilizations and the Remaking of World Order (New York: Touchstone, 1996). 
Huntington, Samuel P. "The Political Modernization of Traditional Monarchies," Daedalus (Summer 1966) 763-788.

Huntington, Samuel P. "Violence in World Politics," Changing Patterns of Military Politics, ed. Samuel P. Huntington (New York: Free Press of Glencoe, 1962).

Ibbetson, Paul A. Living Under The Patriot Act: Educating A Society (Bloomington: Author House, 2007).

Ikenberry, G. John. "The Myth of Post-Cold War Chaos," Foreign Affairs 75.3 (May/June 1996) 79-91.

Indyk, Martin S. "The Iraq War Did Not Force Gadaffi's Hand," The Brookings Institution: Global Politics, March 2004, 21 May 2007 <http://www.brookings. edu/views/op-ed/indyk/20040309.htm>.

Institute for North Korean Studies. "Who is Kim Chong-Il," The Institute for North Korean Studies (Seoul: INKS, 1980).

Institute for South-North Korea Studies. The True Story of Kim Jong-Il (Seoul: ISNK, 1985).

International Atomic Energy Agency. "NPT documents, Facts, and Figures," International Atomic Energy Agency, 5 March $2007<\mathrm{http} / /$ www.iaea.org/Public ations/Documents/Treaties/npt.html>.

International Security Research Group. ISRG Nuclear Proliferation Dossier: Rogue States, 11 Nov. $2007<\mathrm{http} / /$ www.security-research.at/proliferation/?page_id=2>.

Irfani, Suroosh. Revolutionary Islam in Iran (London: Zed Books, 1983).

Jackson, R. H., and P. Owens. "The Evolution of World Society," The Globalization of World Politics, eds. J. Bayliss and Steve Smith (Oxford: Oxford University Press, 2005).

Jaeger, Paul T., John Carlo Bertot, and Charles McClure. "The Impact of the USA PATRIOT Act on Collection \& Analysis of Personal Information Under the FISA," Government Information Quarterly 20.3 (2003) 295-314, 6 Jan. 2007 $<$ http://proquest.umi.com>.

Jameson, Fredric. The Prison-House of Language: A Critical Account of Structuralism and Russian Formalism (Princeton: Princeton University Press, 1974).

Jeffries, Ian. North Korea, a Guide to Economic and Political Developments: Guides to Economic and Political Developments in Asia (New York: Routledge, 2006). 
Jehl, Douglas. "Iran is Reported Acquiring Missiles," New York Times, 8 April 1993, 6 April $2007<$ www.nytimes.com>.

Jenkins, Brian M. "International Terrorism," The Use of Force: Military Power \& International Politics, $6^{\text {th }}$ ed., eds. Robert J. Art and Kenneth Waltz (Lanham: Rowman, 2004).

Jervis, Robert. "Cooperation Under the Security Dilemma," Conflict After the Cold War: Arguments on Causes of War and Peace, $2^{\text {nd }}$ ed., ed. Richard K. Betts (New York: Pearson-Longman, 2002).

Jervis, Robert. "Cooperation Under the Security Dilemma," World Politics 30.2 (Jan. 1978) $167-214$.

Jervis, Robert. "Hypotheses on Misperception," World Politics 20.3 (April 1968) 454479.

Jervis, Robert. "International Primacy: Is the Game Worth the Candle?" International Security 17.4 (Spring 1993) 52-67.

Jervis, Robert. "The Political Effects of Nuclear Weapons: A Comment," INR 6338 Strategic Studies Reader, Florida International University, Miami, FL (Fall 2005) 70.

Jervis, Robert. "The Security Dilemma," Conflict After the Cold War: Arguments on the Causes of War and Peace, $2^{\text {nd }}$ ed., ed. Richard K. Betts (New York: PearsonLongman, 2005).

Jervis, Robert. System Effects: Complexity in Political and Social Life (Princeton: Princeton University Press, 1997).

Job, Brian L., ed. The Insecurity Dilemma: National Security of the Third World States (Boulder: Lynne Rienner, 1992).

Jong Il, Kim. "On the Juche Idea," Treatises Sent to the National Seminar on the Juche Idea Held to Mark the 70th Birthday of the Great Leader Comrade Kim Il Sung, 31 March 1982, 15 Jan. 2007 <www1.koreanp.co.jp/pk/062nd issue/98092410.h tm\#4.\%20 THE\%20GUIDING\%20PRINCIPLES\%20OF\%20THE\%20JUCHE\% 20IDEA>.

Jong Il, Kim. On the Juche Philosophy (Pyongyang: Foreign Languages Publishing House, 2002).

Johnson, Chalmers. Nemesis: The Last Days of the American Republic (New York: Holt, 2006). 
Joyner, Daniel, ed. Non-proliferation Export Controls: Origins, Challenges, and Proposals for Strengthening (Burlington: Ashgate, 2006).

Juche Idea Study Group of England. The Juche Idea, 2004, 28 Oct.2007<http://www. korea-dpr.com/users/jisge/database/db_articles.html>.

Kagan, Robert. Paradise and Power: America and Europe in the New World Order (London: Atlantic Books, 2003).

Kahn, Herman. On Thermonuclear War (Princeton: Princeton University Press, 1960).

Kamrava, Mehran. The Modern Middle East: A Political History Since the First World War (Berkeley and Los Angeles: University of California Press, 2005).

Kane, Thomas. Theoretical Roots of US Foreign Policy: Machiavelli and American Unilateralism (New York: Routledge, 2006).

Kant, Immanuel. Critique of Pure Reason, trans. Norman Kemp, intro. Howard Caygill Smith (New York: Palgrave, 2003).

Kaplan, Amy, and Donald E. Pease, eds. Cultures of United States Imperialism (Durham: Duke University Press, 1993).

Kaplan, Morton. System and Process in International Politics (New York: Wiley, 1957).

Kapuscinski, Ryszard. Shah of Shahs, trans. William R. Brand and Katarzyna Brand (New York: Vintage, 1992).

Karantonis, Antonio. Perspectives of an Iconoclast: Writings in Latin American Studies \& International Relations (Victoria, British Columbia: Trafford Publishing, 2005).

Karl, Terry. The Paradox of Plenty (Berkeley and Los Angeles: University of California Press, 1997).

Kassop, Nancy. "The War Power \& Its Limits," Presidential Studies Quarterly 33.3 (2003) 509-529, 10 Jan. $2007<$ http://proquest.umi.com>.

Katona, Peter, John P. Sullivan, and Michael D. Intriligator, eds. Countering Terrorism and WMD: Creating a Global Counter-Terrorism Network (New York: Routledge, 2006).

Katz, Mark N., ed. Revolution: International Dimensions (Washington, D.C.: Congressional Quarterly Press, 2001). 
Katzenstein, Peter J. "Introduction: Alternative Perspectives on National Security," The Culture of National Security: Norms and Identity in World Politics, ed. Peter J. Katzenstein (New York: Columbia University Press, 1996).

Katzenstein, Peter, and Robert O. Keohane, eds. Anti-Americanisms in World Politics (Ithaca: Cornell University Press, 2007).

Keddie, Nikki R. Modern Iran: Roots and Results of Revolution (New Haven: Yale University Press, 2003).

Kegley, Charles. W., and E. R. Wittkopf. American Foreign Policy: Pattern \& Process (New York: St. Martin's Press, 1996).

Keith, Agnes N. Children of Allah (Boston: Atlantic Monthly Press, 1966).

Kennan, George F. "Diplomacy in the Modern World," Classics of International Relations, ed. John A. Vazquez (Englewood Cliffs: Prentice Hall, 1986).

Kennedy, Paul P. "Few Planes Using Guatemalan Base: Most Retalhuleu Personnel Appear to Have Left Area," New York Times, 17 April 1961, 24 May 2007 $<\mathrm{http} / / / \mathrm{www}$. latinamericanstudies.org/bay-of-pigs/NYT-4-17-61.htm>.

Kenworthy, E. W. "US Avoiding Questions On Cuba Bombing Details," New York Times, 17 April 1961, p. 1, 23 May $2007<$ http://www.latinamericanstudies.org/ bay-of-pigs/NYT-4-17-61g.htm>.

Keohane, Robert O. International Institutions \& State Power: Essays in International Relations Theory (London: Westview Press, 1989).

Keohane, Robert O., and Joseph S. Nye, Power \& Interdependence: World Politics in Transition, $2^{\text {nd }}$ ed. (New York: Longman, 1989).

Keylor, William R. The 20th Century World: An International History, $3^{\text {rd }}$ ed. (Oxford: New York, 1996).

Key-Young, Son. South Korean Engagement Policies And North Korea: Identities, Norms and the Sunshine Policy (New York: Routledge, 2006).

Khadduri, Majid. Modern Libya: A Study in Political Development (Baltimore: Johns Hopkins University Press, 1968).

Khalifa, Mohamed. The Effect of the Leader's Belief System on Foreign Policy: The Case of Libya, diss. Florida State University, 1990, UMI Dissertation Information Service (Ann Arbor, Michigan, 1990). 
Khalilzad, Zalmay M. From Containment to Global Leadership: America \& the World After the Cold War (Santa Monica: RAND Corporation, 1995).

Khomeini, Ruhollah. Ayatollah Khomeini On Issues Related to the Struggle of the Muslim People of Iran (Tehran: Consulate General of the Islamic Republic of Iran, 1980).

Khomeini, Ruhollah. "Collected Speeches," Islamic Republic of Iran Broadcasting (IRIB), World Service, English translation, 27 May $2007<$ http://www.irib.ir/ worldservice/imam/speech/Default.htm>.

Khomeini, Ruhollah. "Collected Speeches." Islamic Republic of Iran Broadcasting Service World-Service, English translation (2005), 18 May $2007<\mathrm{http}: / /$ www. irib.ir/ worldservice/imam/speech/16.htm>.

Khomeini, Ruhollah. Islam and Revolution Vol. 1: Writings and Declaration of Imam Khomeini (1941-1980), trans. Hamid Algar (Berkeley: Mizan Press, 1981).

Khomeini, Ruhollah. Islam and Revolution: Writings and Declarations of Imam Khomeini, trans. Hamid Algar (Mizan Press: Berkeley, 1981).

Khomeini, Ruhollah. Governance of the Jurist (Velayat-e Faqeeh): Islamic Government, trans. Hamid Algar (Tehran: The Institute for Compilation and Publication of Imam Khomeini's Works) 18 May $2007<\mathrm{http} / /$ www.iranchamber. com/history/rkhomeini/ayatollah_khomeini.php>.

Khomeini, Ruhollah. "The Speeches of Ayatollah Khomeini," BBC World Service: Persian Branch, 26 May $2007<\mathrm{http} / / / \mathrm{www} . b b c . c o . u k /$ persian/ revolution/kho meini.shtml\#04>.

Khong, Yuen Foong. "Seduction by Analogy in Vietnam: The Malaya \& Korea Analogies," American Foreign Policy: Theoretical Essays, $3^{\text {rd }}$ ed., ed. G. John Ikenberry (New York: Longman, 1999).

Khorrami, Mohammad Mehdi. "The Islamic Revolution," PBS Online: Beyond the Veil, 26 May $2007<\mathrm{http}: / /$ www.internews.org/visavis/BTVPagesTXT/Theislamicrevo lution.html>.

Khrushchev, Nikita Sergeyevich. Special Report to the 20th Congress of the Communist Party of the Soviet Union - Khrushchev's Secret Speech, Closed Session, February 24-25, 1956, First Secretary Nikita Sergeyevich Khrushchev: The Cult of the Person, 16 Aug. $2007<\mathrm{http}: / /$ www.ebbemunk.dk/stalin/krushchev1.html>. 
Kihss, Peter. "Cuban Exiles' Chief Calls for Help by 'Freedom Loving Peoples' to Oust Castro, Miro Issues Plea; Council Departs, Rebel Leaders Leave Hotel Headquarters Here for an Undisclosed Destination," New York Times, 18 April 1961, p. 15, New York Times Archive, 25 May 2007 <www.nytimes.com>.

Kile, Shannon N., ed. Stockholm International Peace Research Institute: Europe and Iran: Perspectives on Non-Proliferation (Oxford: Oxford University Press, 2005).

Kim, Djun Kil. The History of Korea: The Greenwood Histories of the Modern Nations (Westport: Greenwood Press, 2005).

Kim, Samuel S., ed. The North Korean System in the Post-Cold War Era (New York: Palgrave, 2001).

Kim, Sung Chull. North Korea Under Kim Jong Il: From Consolidation to Systemic Dissonance (Albany: State University of New York Press, 2006).

Kissinger, Henry. Diplomacy (New York: Simon \& Schuster, 1994).

Klare, Michael. "The Ambivalent Crusade: Washington's War Against Proliferation," INR 6338 Strategic Studies Reader, Florida International University, Miami, FL (Fall 2005) 199-203.

Klare, Michael. Rouge States \& Nuclear Outlaws: America's Search for a New Foreign Policy (New York: Hill and Wang, 1995).

Korea Institute for National Unification. "The Impact of Personality Cult in North Korea: Studies Series 04-03," Korea Institute for National Unification KINU (2004), 17 Aug. $2007<$ http://www.kinu.or.kr/eng/>.

Korean Central News Agency. "KCNA on DPRK's Nuclear Deterrent Force," Korean Central News Agency, Pyongyang, Democratic People's Republic of Korea, 9 June 2003, 16 Aug. $2007<$ http://www.kcna.co.jp/index-e.htm >.

Korean Central News Agency. "KCNA on US Reckless Nuclear War Scenario," Korean Central News Agency, Pyongyang, Democratic People's Republic of Korea, 13 March 2002, 12 August $2007<$ http://www.kcna.co.jp/i ndex-e.htm>.

Korean Central News Agency. "Statement of Foreign Ministry Spokesman Blasts UNSC's Discussion of Korean Nuclear Issue," Korean Central News Agency, Pyongyang, Democratic People's Republic of Korea, 7 April 2003, 14 August $2007<$ http://www.kcna.co.jp/index-e.htm>. 
Kornbluh, Peter. Bay of Pigs Declassified: The Secret CIA Report on the Invasion of Cuba (New York: New Press, 1998).

Krauthammer, Charles. "The Unipolar Moment," Foreign Affairs 70.1 (1990/91) 23-33.

Kristol, William. "Toward Regime Change in North Korea," Project For the New American Century, 22 Nov. 2004, 16 Aug. $2007<\mathrm{http}$ ://www.newamericancent ury.org/eastasia2004.htm >.

Kryzanek, Michael J. US-Latin American Relations, $3^{\text {rd }}$ ed. (Westport: Praeger, 1996).

Kuhn, Thomas. The Structure of Scientific Revolutions, $3^{\text {rd }}$ ed. (Chicago: University of Chicago Press, 1996).

Kumar, Radha. "The Troubled History of Partition," Foreign Affairs 76.1 (Jan/Feb 1997).

Kupchan, Charles, and Clifford Kupchan. "The Promise of Collective Security," International Security 20:1 (Summer 1995) 52-61.

Kurth, James R. "A Widening Gyre: The Logic of American Weapons Procurement," American Foreign Policy: Theoretical Essays, $3^{\text {rd }}$ ed., ed. G. John Ikenberry (New York: Longman, 1999).

Kurth-Cronin, Audrey. "Behind the Curve: Globalization and International Terrorism," International Security 27.3 (Winter 2002/2003).

Kurzman, Charles. The Unthinkable Revolution in Iran (Cambridge: Harvard University Press, 2004).

Lacan, Jacques. Ecrits: A Selection, trans. Bruce Fink (New York: W.W. Norton, 2002).

Lacorne, Denis, and Tony Judt, eds. With US or Against US: Studies in Global AntiAmericanism (New York: Palgrave, 2005).

Lamrani, Salim, ed. Superpower Principles: US Terrorism Against Cuba (Monroe: Common Courage Press, 2005).

Lankov, Andrei. From Stalin to Kim Il Sung: The Formation of North Korea 1945-1960 (New Brunswick: Rutgers University Press, 2002).

Lapidus, Ira M. A History of Islamic Societies, $2^{\text {nd }}$ ed. (Cambridge: University of Cambridge Press, 2002). 
Laszlo, Ervin. The Systems View of the World: A Holistic Vision for Our Time Advances in Systems Theory, Complexity, and the Human Sciences (Cresskill: Hampton Press, 1996).

Laszlo, Ervin. The Systems View of the World: The Natural Philosophy of the New Developments in the Sciences (New York: George Braziller, 1972).

Layne, Christopher. "From Preponderance to Offshore Balancing," America's Strategic Choices, eds. Michael Brown, et al. (Cambridge: Massachusetts Institute of Technology University Press, 1997).

Layne, Christopher. "From Preponderance to Offshore Balancing: America's Future Grand Strategy," International Security 22.1 (Summer 1997) 86-124.

Layne, Christopher. "Kant or Cant: The Myth of the Democratic Peace," International Security 19.2 (Fall 1994) 5-49.

Layne, Christopher. "Rethinking American Grand Strategy: Hegemony or Balance of Power in the Twenty-First Century?" World Policy Journal 15.2 (Summer 1998) $8-41$.

Layne, Christopher. "The Unipolar Illusion: Why New Great Powers Will Rise," International Security 17.4 (Spring 1993) 5-51.

Leahy, Patrick. THE UNITING AND STRENGTHENING AMERICA BY PROVIDING APPROPRIATE TOOLS REQUIRED TO INTERCEPT AND OBSTRUCT TERRORISM (USA PATRIOT) ACT OF 2001, H.R. 3162: SECTION-BYSECTION ANALYSIS, 29 June $2007<\mathrm{http} / / /$ eahy.senate.gov/press/200110/1024 01a.html>.

Lebovic, James. Deterring International Terrorism and Rogue States: US National Security Policy After 9/11 (New York: Routledge, 2006).

Lee, Grace. "The Political Philosophy of Juche," Stanford Journal of East Asian Affairs 3.1 (Spring 2003), 13 April $2008<$ http://209.85.165.104/search?q=cache:u2Oxl FATKy8J:www.stanford.edu/group/sjeaa/journal3/korea1.pdf+Lee,+Grace.+\%E2 $\% 80 \% 9$ CThe+Political + Philosophy + of + Juche $\%$ E2\%80\%9D\&hl=en\&ct $=$ clnk\&c $\mathrm{d}=1 \& \mathrm{gl}=$ us\&client $=$ firefox-a $>$.

Lee, Hy-Sang. North Korea: A Strange Socialist Fortress (Westport: Praeger, 2001).

Leffler, Melvyn P. "The American Conception of National Security and the Beginnings of the Cold War, 1945-1948," American Historical Review 89.2 (April 1984) 346381. 
Leffler, Melvyn P. A Preponderance of Power: National Security, The Truman Administration, \& the Cold War (Stanford: Stanford University Press, 1992).

Lenin, Vladimir I. "The Place of Imperialism in History," Classics of International Relations, ed. John A. Vazquez (Englewood Cliffs: Prentice Hall, 1986).

Lennon, Alexander T. J., ed. Contemporary Nuclear Debates: Missile Defenses, Arms Control, and Arms Races in the Twenty-First Century (Cambridge:

Massachusetts Institute of Technology, 2002).

Lennon, Alexander T. J., and Camille Eiss, eds. Reshaping Rogue States: Preemption, Regime Change, \& US Policy Toward Iran, Iraq, and North Korea (Cambridge: Massachusetts Institute of Technology Press, 2004).

Leverett, Flynt. "Why Libya Gave Up on the Bomb," New York Times, 23 Jan. 2004, 3 March $2007<$ www.nytimes.com>.

Levy, Jack S. "Organizational Routines and the Causes of War," International Studies Quarterly 30.2 (June 1986).

Levy, Jack S. "The Causes of War: A Review of Theories and Evidence," Behavior, Society, and Nuclear War: Vol. 1, eds. Philip E. Tetlock, et al. (New York: Oxford University Press, 1989).

Levy, Jack S. "The Offensive/Defensive Balance of Military Technology: A Theoretical and Historical Analysis," International Studies Quarterly 28.2 (June 1984) 219238.

Levy, Jack S. "The Offensive/Defensive Balance of Military Technology," Conflict After the Cold War: Arguments on Causes of War \& Peace, $2^{\text {nd }}$ ed., ed. Richard K. Betts (New York: Longman, 2002).

Lewis, Bernard. "License to Kill: Usama bin Ladin's Declaration of Jihad," Foreign Affairs 77.6 (Nov/Dec 1998) 15.

Libyan Arab Republic Ministry of Information and Culture. "The Revolution of the $1^{\text {st }}$ of September: The Fourth Anniversary," Libyan Arab Republic Ministry of Information and Culture, The General Administration for Information, Dar AlHakika, Benghazi, 1973.

Lieber, Robert J. "Foreign Policy and American Primacy: Eagle Rules?" Foreign Policy and American Primacy in the 21st Century, ed. Robert J. Lieber (Upper Saddle River: Prentice Hall, 2002). 
Lintner, Bertil. Great Leader, Dear Leader: Demystifying North Korea Under the Kim Clan (Chiang Mai: Silkworm Books, 2005).

Liska, George. Twilight of Hegemony: The Late Career of Imperial America (Lanham: University Press of America, 2003).

Litwak, Robert S. Rogue States and US Foreign Policy: Containment After the Cold War (Baltimore: Johns Hopkins University Press, 2000).

Looney, Robert E. Economic Origins of the Iranian Revolution (Oxford: Pergamon Press, 1982).

Lynch, Grayston L. Decision for Disaster: The Battle of the Bay of Pigs (New York: Pocket Books/Simon Shuster, 1998).

Lynn-Jones, Sean. "Offense-Defense Theory and Its Critics," Security Studies 4.4 (Summer 1995) 660-691.

Lyotard, Jean Francois, and Jean-Loup Thebaud. Just Gaming, trans. Wlad Godzich (Minneapolis: University of Minnesota Press, 1999).

Lyotard, Jean Francois. The Postmodern Condition: A Report on Knowledge, trans. Geoff Bennington and Brian Massumi, forward Fredric Jameson (Minneapolis: University of Minnesota Press, 1984).

Macro-History: Pre-History to the Twenty-First Century. "The Iranian Revolution: Profile of The Islamic Republic of Iran, 1946-Present," Macro-History: PreHistory to the Twenty-First Century, 26 May $2007<$ http://www.fs mitha.com/h2/ ch29ir.html>.

Mailman, Stanley, Jeralyn E. Merritt, Theresa M. B. Van Vliet, and Stephen Yale-Loehr. Uniting and Strengthening America by Providing Appropriate Tools Required to Intercept and Obstruct Terrorism (USA PATRIOT ACT) Act of 2001: An Analysis (Newark: Matthew Bender \& Co./Lexis-Nexis Group, Rel. 1-3/02 Pub. 1271, 2002).

Malcolm, Ben. White Tigers (Washington D.C.: Brasseys, 1996).

Marino, Soraya Castro. "The Cuba-US Conflict: Notes for Reflection in the Context of the War Against Terrorism," Foreign Policy Toward Cuba: Isolation or Engagement? eds. Michele Zebich-Knos and Heather N. Nicol (Lanham: Lexington Books, 2005). 
Martin, Bradley K. "The What-If Question," Nautilus Policy Forum Online, no. 00-02, 15 March 2000, 21 Aug. $2007<$ http://www.nautilus.org/fora/security/0002C_M artin.html>.

Martin, Bradley K. Under the Loving Care of the Fatherly Leader: North Korea and the Kim Dynasty (New York: Thomas Dunne Books/St. Martin's Press, 2004).

Martin, Lionel. The Early Fidel (Secaucus: Lyle Stuart, 1978).

Matthews, Herbert. Fidel Castro (New York: Simon \& Schuster, 1969).

Matthews, Herbert. Revolution in Cuba (New York: Scribner's, 1975).

May, Ernest R. American Imperialism (New York: Atheneum, 1968).

Maynes, Charles William. "Principled Hegemony," World Policy Journal 14.3 (Fall 1997) 31-37.

McClelland, Charles. "General Systems Theory in International Relations," International Security Systems: Concepts \& Models of World Order, ed. Richard B. Gray (Itasca: F. E. Peacock, 1969).

McLuhan, Marshall. Understanding Media: The Extensions of Man, intro. Lewis H. Lapham (Cambridge: Massachusetts Institute of Technology Press, 2002).

Mearsheimer, John J. "Back to the Future: Instability in Europe After the Cold War," International Security 15:1 (Summer 1996) 5-56.

Mearsheimer, John J. "Why We Will Soon Miss the Cold War," The Atlantic 266.2 (Nov. 1990) 35-50, 11 April $2008<\mathrm{http} / / / 209.85 .165 .104 /$ search?q=cache:G9Xl PiSXnM8J:mearsheimer.uchicago.edu/pdfs/A0014.pdf+Mearsheimer,+John+J.+ $\% \mathrm{E} 2 \% 80 \% 9 \mathrm{CWhy}+\mathrm{We}+\mathrm{Will}+$ Soon+Miss + the + Cold + War, $\% \mathrm{E} 2 \% 80 \% 9 \mathrm{D} \& \mathrm{hl}=$ en $\& c t=$ clnk $\& c d=3 \& g l=u s \& c l i e n t=$ firefox $-\mathrm{a}>$.

Medeiros, Evan S. Chasing the Dragon: Assessing China's System of Export Controls for WMD-Related Goods and Technologies (Santa Monica: RAND Corp., 2005).

Medlicott, Carol. "Symbol and Sovereignty in North Korea," SAIS Review 25.2 (Summer/Fall 2005) 69-79.

Meyers, David. Regional Hegemons: Threat Perception \& Strategic Response (Boulder: Westview Press, 1991).

Migdal, Joel S. Strong Societies \& Weak States: State-Society Relations \& State Capabilities in the Third World (Princeton: Princeton University Press, 1988). 
Mills, C. Wright. The Sociological Imagination, afterword Todd S. Gitlin (New York: Oxford University Press, 2000).

Mill, J. S. Considerations on Representative Government (London: Parker, Son and Bourn Publishers, 2006).

Millett, Allan R. "A Reader's Guide to the Korean War," Journal of Military History 61.3 (July 1997) 583-597.

Milner, Helen, and Jack Snyder, "Lost Hegemony?" International Organization 42.4 (Autumn 1988) 749-750.

Moaddel, Mansoor. Class, Politics, and Ideology in the Iranian Revolution (New York: Columbia University Press, 1994).

Modelski, George, "The Long Cycle of Global Politics \& the Nation State," Comparative Studies in Society \& History 20 (1978) 214-235.

Moin, Baqer. Khomeini: Life of the Ayatollah (New York: Thomas Dunne Books/St. Martin's Press, 1999).

Montaner, Carlos Alberto. Fidel Castro and the Cuban Revolution: Age, Position, Character, Destiny, Personality, and Ambition (New Brunswick: Transaction, 2007).

Montgomery-Massingberd, Hugh, ed. Burke's Royal Families of the World. Volume II: Africa \& The Middle East (London: Burke's Publications Ltd., 1980).

Moon, Chung-in, and Jong-Yun Bae. "The Bush Doctrine and the North Korean Nuclear Crisis," Confronting the Bush Doctrine: Critical Views From the Asia-Pacific, eds. Mel Gurtov and Peter Van Ness (London: Routledge-Curzon, 2005).

Moore, Mike. "Rogue States and Nuclear Outlaws: America's Search for a New Foreign Policy," The Bulletin of the Atomic Scientists 51 (S/O 1995).

Morgan, Michael L., ed. Classics of Moral And Political Theory, $4^{\text {th }}$ ed. (Indianapolis: Hackett Publishing, 2005).

Morgenthau, Hans J. Politics Among Nations: The Struggle for Power \& Peace, $4^{\text {th }}$ ed. (New York: Alfred Knopf, 1966).

Morgenthau, Hans J. Politics Among Nations: The Struggle for Power \& Peace, $6^{\text {th }}$ ed. revised, ed. Kenneth W. Thompson (New York: Alfred A. Knopf, 1985). 
Morley, Morris, and Chris McGillion. Unfinished Business: America and Cuba after the Cold War, 1989-2001 (Cambridge: Cambridge University Press, 2002).

Mousseau, Michael. "Market Civilization \& Its Clash with Terror," International Security 27.3 (Winter 2002/2003).

Munson, Henry, Jr. Islam and Revolution in the Middle East (New Haven: Yale University Press, 1988).

Myers, Robert John. US Foreign Policy in the Twenty-First Century: The Relevance of Realism (Baton Rouge: Louisiana State University Press, 1999).

Naden, Corinne J., and Rose Blue. Fidel Castro And the Cuban Revolution (Greensboro: Morgan Reynolds, 2006).

Nassauer, Otfried. "Nuclear Sharing in NATO: Is it Legal?" Institute for Energy and Environmental Research, May 2001, 11 April $2007<\mathrm{http}$ //www.ieer.org/sdafiles /vol_9/9-3/nato.html>.

Nathan, K. S. "South Asia and U.S. Security Policy: US Engagement Policy in a Changing Asia," National Defense University's Twentieth Annual Pacific Symposium, 1-2 March 1999 (NAPSNET Special Report, 23 July 1999), 21 Aug. $2007<\mathrm{http}: / /$ www. ndu.edu/inss/symposia/pacific $99 /$ ksnathan.html $>$.

Neack, Laura. The New Foreign Policy: US Comparative Foreign Policy in the 21st Century (Lanham: Rowman \& Littlefield, 2003).

New York Times. "Chanting Cubans Back Castro Here, 1,000 in Midtown March Dispersed by Police," New York Times, 18 April 1961, p. 1, 25 May $2007<$ http:// www. latinamericanstudies.org/bay-of-pigs/NYT-4-18-61 c.htm>.

New York Times. "Rivalries Beset Top Cuban Exiles Castro Foes, Planning Own Regime, Are Divided Over Politics and Ideologies," New York Times, 9 April 1961, 25 May 2007 < http://www.latinamericanstudies.org/bay-of-pigs/rivalries .htm>.

New York Times. "Statements Broadcast by Castro Regime," New York Times, 18 April 1961, p. 14, 25 May 2007 <http://www.latinamericanstudies.org/bay-of-pigs/NYT $-4-18-61 \mathrm{e} . \mathrm{htm}>$.

New York Times. "Text of Secretary Rusk's News Conference, Including Observations on Cuba," New York Times, 18 April 1961.p. 18, 23 May $2007<$ http://www.latin americanstudies.org/bay-of-pigs/NYT-4-18-61m.htm>. 
New York Times. "US Stand Against Reds in Cuba Has Its Roots in Monroe Doctrine," New York Times, 19 April 1961, 21 May $2007<\mathrm{http}$ ://www.latinamericanstudies. org/bay-of-pigs/NYT-4-19-61b.htm>.

Newton, Isaac. "Principa," The Portable Enlightenment Reader, ed. and intro. Isaac Kramnick (New York: Penguin Books, 1995).

Nicholson, Michael. "The Continued Significance of Positivism?" International Theory: Positivism \& Beyond, eds. Steve Smith, Ken Booth, Martha Zalewski (Cambridge: Cambridge University Press, 1996).

Nietzsche, Friedrich. "On Truth and Lying in a Non-Moral Sense," The Norton Anthology of Theory and Criticism, eds. Vincent B. Leitch, William E. Cain, Laurie A. Fink, Barbara E. Johnson, John McGowan, and Jeffery J. Williams (New York: W.W. Norton, 2001).

Ninkovich, Frank A. The United States and Imperialism (Oxford: Blackwell, 2001).

Numani, Farhad, and Sohrab Behdad. Class and Labor in Iran: Did the Revolution Matter? (Syracuse: Syracuse University Press, 2006).

Nutter, John Jacob. The CIA's Black Ops: Covert Action, Foreign Policy, and Democracy (New York: Prometheus Books, 2000).

Obeidi, Amal S. M. Political Culture in Libya (London: Curzon, 2001).

Oberdorfer, Don. The Two Koreas: A Contemporary History, Revised and Updated Edition (New York: Basic Books, 2001).

Ogden, Christopher. "Inside Kim Jong-Il's Brain: 'Baffling Outsiders Is What I Do Best," Time 148, no. 15 (October 7, 1996).

Oh, Kongdan, and Ralph Hassig. North Korea Through the Looking Glass (Washington D.C.: Brookings Institution, 2000).

O'Hanlon, Michael E. "A Flawed Masterpiece," Foreign Affairs 81.3 (May/June 2002) 47-63, 11 April $2008<$ http://209.85.165.104/search?q=cache:Vk9GspbAyFQJ: www.brookings.edu/views/articles/ohanlon/20020501.pdf $+\mathrm{O} \% \mathrm{E} 2 \% 80 \% 99 \mathrm{Hanlo}$ n,+Michael+E.+\%E2\%80\%9CA+Flawed+Masterpiece, \%E2\%80\%9D\&hl=en\&ct $=$ clnk\&cd $=4 \& g \mathrm{l}=$ us\&client $=$ firefox-a $>$.

O'Hanlon, Michael E., Susan E. Rice, and James B. Steinberg. "The New National Security Strategy and Preemption," Brookings Institution, 20 July $2007<w w w$. brookings.edu/dybdocroot/views/papers/ohanlon/ 20021114.pdf>. 
Olwig, Kenneth Robert. Landscape, Nature, and the Body Politic: From Britain's Renaissance to America's New World (Madison: University of Wisconsin Press, 2002).

Omid, Homa. Islam and the Post-Revolutionary State in Iran (New York: St. Martin Press, 1994).

Osieja, Helen. Economic Sanctions as an Instrument of US Foreign Policy: The Case of the US. Embargo Against Cuba (Boca Raton: Dissertation.com, 2005).

O'Sullivan, Meghan L. "Replacing the Rogue Rhetoric: A New Label Opens the Way to a Better Policy," Brookings Review 18.4 (Fall 2000).

Owen, John. "How Liberalism Produces Democratic Peace," International Security 19:2 (Fall 1994).

Pahlavi, Mohammed Reza. The White Revolution of Iran, English trans. (Tehran: Imperial Pahlavi Library, 1967).

Palka, Eugene J., and Francis A. Galgano. North Korea: Geographic Perspectives (Guilford: McGraw Hill, 2004).

Palma, G. "Dependency: A Formal Theory of Underdevelopment or a Methodology for the Analysis of Concrete Situations of Underdevelopment?" World Development 6 (1978) 881-924.

Palmer, Michael A. Guardians of the Gulf: A History of America's Expanding Role in the Persian Gulf, 1883-1992 (New York: Simon and Schuster, 1992).

Park, Han S. The Development Strategy of Self-Reliance (Juche) and Rural Development in the Democratic People's Republic of Korea (New York: Routledge, 2002).

Park, Han S. "The Nature and Evolution of Juche Ideology," North Korea: Ideology, Politics, Economy, ed. Han S. Park (Englewood Cliffs: Prentice Hall, 1996).

Park, Hyeong-Jung, and Lee Kyo-Duk. Continuities and Changes in the Power Structure and the Role of Party Organizations Under Kim Jong-Il's Reign (Seoul: Korea Institute for National Unification, 2005) 17 Aug. 2007 <http://www.kinu.or.kr/ eng/>.

Parsa, Misagh. Social Origins of the Iranian Revolution (New Brunswick: Rutgers University Press, 1989).

Paterson, Thomas G. American Imperialism and Anti-Imperialism (New York: T. Y. Crowell, 1973). 
Paterson, Thomas G. Contesting Castro: The US and the Triumph of the Cuban Revolution (New York: Oxford University Press, 1994).

Patton, Paul. Introduction, The Gulf War Did Not Take Place, by Jean Baudrillard, trans. Paul Patton (Bloomington: Indiana University Press, 1991).

PBS Online. "Key Events: Iran Since 1921," PBS Online, 27 May $2007<\mathrm{http}$ ://www. pbs.org/newshour/indepth_coverage/middle_east/iran/timeline.html $>$.

People's Daily Online. "War to Resist US Aggression and Aid Korea Marked in DPRK," People's Daily Online, 26 October 2000, Beijing, People's Republic of China, English Version, 11 Jan. $2007<$ http://english.people.com.cn/>.

Perez, Louis A. Cuba and the US: Ties of Singular Intimacy, $3^{\text {rd }}$ ed. (Athens: University of Georgia Press, 2003).

Perez, Louis A. Cuba: Between Reform and Revolution, $2^{\text {nd }}$ ed. (New York: Oxford, 1995).

Perez-Stable, Marifeli. The Cuban Revolution: Origins, Course, and Legacy, $2^{\text {nd }}$ ed. (Oxford: Oxford University Press, 1999).

Pew Research Center for the People and Press. The Pew Global Attitudes Project, 2007, Global Unease With Major World Powers: Rising Environmental Concern in 47Nation Survey, 27 June 2007, 7 July $2007<$ http://pewglobal.org>.

Pinkston, Daniel. "Domestic Politics and Stakeholders in the North Korean Missile Development Program," Non-Proliferation Review: Center for Non-Proliferation Studies, Monterey Institute for International Studies (Summer 2003) 1-15, 16 Aug. $2007<$ cns.miis.edu/pubs/npr/vol10/102/102pink.pdf $>$.

Plato, "Theaetetus," trans. Benjamin Jowett, Project Gutenberg Release \#1726, April 1999, 27 Dec. 2007, <http://www.gutenberg.org/dirs/etext99/thtus10.txt>.

Portal, Jane. Art Under Control in North Korea (London: Reaktion Books, 2005).

Posen, B. R. The Sources of Military Doctrine: France, Britain and Germany Between the World Wars (Ithaca: Cornell University Press, 1984).

Powaski, Ronald E. Return to Armageddon: The United States and the Nuclear Arms Race, 1981-1999 (New York: Oxford University Press, 2000).

Powers, Thomas F. "Can We Be Secure \& Free?" Public Interest 151: 3-21, National Affairs Incorporated, Washington D.C., Spring 2003, 12 Feb. $2007<$ www.http:// proquest.umi.com>. 
Prados, John. Presidents' Secret Wars: CIA and Pentagon Covert Operations From World War II Through the Persian Gulf War (Chicago: Ivan R. Dee Publishers, 1996).

Pratt, Keith. Everlasting Flower: A History of Korea (London: Reaktion Books, 2006).

Prestowitz, Clyde. Rogue Nation: American Unilateralism \& the Failure of Good Intentions (New York: Basic Books, 2003).

Public Broadcasting System News Hour. "Interview with Fidel Castro," PBS Online News-Hour, 12 Feb. 1985, 17 July $2007<w w w . p b s . o r g / n e w s h o u r / b b / l a t i n \_a m e r$ ica/cuba /castro_2-12-85.html>.

Purdum, Todd S. "Bush Warns of Wrathful, Shadowy and Inventive War," New York Times, 17 September 2001.

Putin, Vladimir, " $43^{\text {rd }}$ Munich Security Conference," 10 Feb. 2007, BBC News Online, 1 June $2007<\mathrm{http}: / /$ news.bbc.co.uk/2/hi/europe/6349287.stm>.

Putnam, Robert. Making Democracy Work: Civic Traditions in Modern Italy (Princeton: Princeton University Press, 1993).

Qaddafi, Muammar, and Edmond Jouve. My Vision, trans. Angela Parfitt (London: John Blake, 2005).

Qaddafi, Muammar. The Green Book, Part I: The Solution of the Problem of Democracy (London: Martin Brian and O'Keeffe, 1976).

Qaddafi, Muammar. The Green Book, Part II: The Solution of the Economic Problem: Socialism (London: Martin Brian and O'Keeffe, 1978).

Qaddafi, Muammar. The Green Book: Vols. 1-3, 21 May $2007<$ http://www.mathaba. net/gci/theory/gb.htm>.

Qaddafi, Muammar. "The Green Book: Vols. 1-3," US Library of Congress, Federal Research Division, Country Studies: Libya, 21 May $2007<\mathrm{http}: / / \mathrm{lcweb} 2 . l o c . g o v /$ frd/cs/lytoc.html\#ly0009>.

Quester, George. Offense and Defense in the International System, $2^{\text {nd }}$ ed. (New Brunswick: Transaction Books, 1988).

Quine, V. W. "Two Dogmas of Empiricism," Challenges to Empiricism, ed. Harold Link-Morick (Belmont: Wadsworth Publishing, 1972).

Quirk, Robert E. Fidel Castro (New York: W.W. Norton, 1993). 
R. S. "Pravda on the Role of the Party and of the Individual," Soviet Studies 5.2 (Oct. 1953) 208-212.

Rabe, Stephen G. Eisenhower and Latin America: The Foreign Policy of Anticommunism (Chapel Hill: University of North Carolina Press, 1988).

Ramesh, Randeep. "The Two Faces of Rumsfeld," The Guardian, 9 May 2003, 11 April $2008<\mathrm{http}: / / \mathrm{www}$. countercurrents.org/iraq-ramesh090503.htm>.

Ray, James L. Global Politics, $2^{\text {nd }}$ ed. (Boston: Houghton Mifflin, 1983).

RCOCI (Regional Cooperation Office for City Information) Working Unit. "Governance, Asia-Pacific Watch, The Regional Cooperation Office for City Information," The RCOCI Working Unit, March 2004, Issue 28, 29 Sept. 2007 $<$ http://unpan1.un.org/intradoc/groups/public/documents/apcity/unpan015658. htm>.

Rees, John. Imperialism and Resistance (New York: Routledge, 2006).

Reston, James. "Rusk Declares Sympathy of Nation for Castro Foes," New York Times, 18 April 1961, 23 May 2007 <http://www.latinamericanstudies.org/bay-of-pigs/ NYT-4-18-611.htm>.

Reynolds, Paul. "Fidel, The World Icon," BBC News Online, 17 Jan. 2007, 22 May 2007 $<$ http://news.bbc.co.uk/2/hi/americas/5243500.stm>.

Reynolds, Paul. "New Mentality for New War," BBC News Online, 22 July 2004, 9 August $2007<$ news.bbc.com.uk/2/hi/Americas/3918655.stm>.

Reynolds, Paul. "US Turns Heat Up on Iran," BBC News Online, 15 Aug. 2007, 1 Oct. $2007<\mathrm{http}: / /$ news.bbc.co.uk/2/hi/americas/6947616.stm>.

Rice, Condoleezza. "Promoting the National Interest," Foreign Affairs 79.1 (Jan/Feb 2000).

Roberts, Brad, ed. Weapons Proliferation in the 1990s: Washington Quarterly Reader (Cambridge: Massachusetts Institute of Technology Press, 1995).

Roberts, J. M. The New Penguin History of the World: Fourth Edition (London: Penguin Books, 2002).

Rocky Mountain Social Science Journal. Rocky Mountain Social Science Journal, 9.2 (April 1972) 93-98, 16 May $2007<$ http://web.pdx.edu/ tothm/essays/essays/tow ard_a_theory_of_the_routiniz.htm\#*>. 
Rodgers, T. J. "British, US Spying Draws Us Closer to Orwell's Big Brother," San Jose Mercury News, 29 Dec. 2005, 7 July 2007 <commondreams.org/views05/1229$35 \mathrm{htm}>$.

Rodriguez, Juan Carlos. The Bay of Pigs and the CIA, Cuban Secret Files on the 1961 Invasion, trans. Mary Todd (Hoboken: Ocean Press, 1999).

Rohde, David. "Musharraf Redraws Constitution," New York Times Online, 22 August 2002, 7 March 2007 <www.nytimnes.com>.

Rosati, Jerel A., ed. Readings in the Politics of US Foreign Policy, $2^{\text {nd }}$ ed. (Fort Worth: Harcourt Brace, 1998).

Rosati, Jerel A. The Politics of US Foreign Policy, $2^{\text {nd }}$ ed. (Fort Worth: Harcourt Brace, 1999).

Rosenau, James N. "Pre-Theories and Theories of Foreign Policy," Approaches to Comparative and International Politics, ed. R. Barry Farrell (Evanston: Northwestern University Press, 1966).

Rosenau, James N. The Scientific Study of Foreign Policy, revised ed. (New York: Nichols Publishing Company, 1980).

Rosenau, James N. Turbulence in World Politics (Princeton: Princeton University Press, 1990).

Rothgeb, John. Defining Power: Force \& Influence in the Contemporary International System (New York: St. Martin's Press, 1993).

Roumani, Jacques. "From Republic to Jamahiriya: Libya's Search for Political Community," Middle East Journal 37.2 (Spring 1983) 151-68.

Rubin, Barry. Paved With Good Intentions: The American Experience in Iran New York: Penguin, 1981).

Ruggie, John G. Constructing the World Polity: Essays on International Institutionalization (New York: Routledge, 1998).

Ruggie, John G. Winning the Peace: America \& World Order in the New Era (New York: Columbia University Press, 1996).

Rumsfeld, Donald. "Take the Fight to the Terrorists," Washington Post, 26 October 2003, B-7, 11 April 2008 <http://www.globalsecurity.org/military/library/news/ 2003/10/mil-031026-usia01.htm $>$. 
Russell, James A., ed. Proliferation of Weapons of Mass Destruction in the Middle East: Directions and Policy Options in the New Century (New York: Palgrave, 2006).

Ryan, David. US Foreign Policy in World History (New York: Routledge, 2000).

Sachedina, Abdulaziz A. "The Development of Jihad in Islamic Revelation and History," Cross, Crescent, and Sword, eds. James Turner Johnson and John Kelsay (Westport: Greenwood Press, 1990).

Sagan, Scott D. "1914 Revisited: Allies, Offense, and Instability," International Security 11.2 (Fall 1986) 151-175.

Sagan, Scott D., and Kenneth N. Waltz. The Spread of Nuclear Weapons: A Debate Renewed (New York: Norton, 2003).

Said, Edward W. "Orientalism," The Norton Anthology of Theory and Criticism, eds. Vincent B. Leitch, William E. Cain, Laurie A. Fink, Barbara E. Johnson, John McGowan, and Jeffery J. Williams (New York: W.W. Norton, 2001).

Said, Edward W. Culture and Imperialism (New York: Vintage Books, 1994).

Saint John, Ronald Bruce. Qaddafi's World Design: Libyan Foreign Policy, 1969-1987 (London: Sagi Books, 1987).

Saint John, Ronald Bruce. "The Ideology of Muammar al-Qadhhafi: Theory and Practice," International Journal of Middle East Studies 15.4 (Nov. 1983) 471490.

Saint John, Ronald Bruce. Libya and the United States: Two Centuries of Strife (Philadelphia: University of Pennsylvania Press, 2002).

Sandler, Stanley. The Korean War: An Interpretative History. No Victors, No Vanquished (Lexington: University Press of Kentucky, 1999).

Sanger, David E., and Jim Yardley. "US Sternly Warns North Korea not to Conduct a Nuclear Test," New York Times, 5 Oct. 2006, 1 March 2007 <www.nytimes.co $\mathrm{m}>$.

Sanger, David E. "Bush Warns Iran on Building Nuclear Arms," New York Times, 19 June 2003, 3 March 2007 <www.nytimes.com>.

Sanger, David E. "In North Korea and Pakistan, Deep Roots of Nuclear Barter," New York Times Online, 24 Nov. 2002, 7 March 2007 <www.nytimes.com>. 
Sanger, David E. "North Korea Reports First Nuclear Arms Test," New York Times, 9 October 2006, 14 Aug. 2007 <www. nytimes.com/2006/10/09/ world/asia/09kor ea.html ?n=Top\%2fNews\%2fWorld\%2fCountries\%20and\%20Territories\%2fNo rth\%20Korea>.

Saussure, Ferdinand. "Course in General Linguistics," The Norton Anthology of Theory and Criticism, eds. Vincent B. Leitch, William E. Cain, Laurie A. Fink, Barbara E. Johnson, John McGowan, and Jeffery J. Williams (New York: W.W. Norton, 2001).

Savada, Andrea Matles, ed. North Korea: A Country Study (Washington D.C.: GPO/ Library of Congress, 1993) 10 April $2007<$ http://countrystudies.us/north-korea/>.

Savada, Andrea Matles., ed. North Korea: A Country Study (Washington D.C.: GPO/ Library of Congress, 1994).

Scammon, William. Fighting Back: The War on Terror From Inside the White House (Washington, D.C.: Regnery Press, 2002).

Schell, Orville. "In the Land of the Dear Leader," Harper's, vol. 293 (July 1996) 58-66.

Scherlen, Renee G. "Venceremos! Castro's Discourse on Cuba's Foreign Policy," Foreign Policy Toward Cuba: Isolation or Engagement? eds. Michele ZebichKnos and Heather N. Nicol (Lanham: Lexington Books, 2005).

Schmitt, Carl. Political Theology: Four Chapters on the Concept of Sovereignty, trans. George Schwab, foreword Tracy B. Strong (Chicago: University of Chicago Press, 2006).

Schmitt, Carl. The Concept of the Political, trans. George Schwab, foreword Tracy B. Strong, commentary Leo Strauss (Chicago: University of Chicago Press, 1996).

Schmitt, Eric. "North Korean Fliers Said to Have Sought Hostages" New York Times, 8 March 2003, 1 April $2007<$ www.nytimes.com>.

Schneider, Barry R. "Post 9/11Challenges \& Borderless Threats," International Affairs Review 15.2 (Fall/Winter) Washington D.C., George Washington University/ Elliot School of Int. Affairs, 2006.

Schneider, Barry R. Future War and Counter-Proliferation: U.S. Military Responses to NBC Proliferation Threats (Westport: Praeger, 1999).

Semple, Janet. Bentham's Prison: A Study of the Panopticon Penitentiary (New York: Oxford University Press, 1993). 
Shanker, Thom. "Global Arms Sales Rise Again, and the US Leads the Pack," New York Times, 20 August 2001, 11 July 2007 <www.nytimes.com>.

Shapiro, Michael J. Methods and Nations: Cultural Governance and the Indigenous Subject (New York: Routledge, 2004).

Shawcross, William. The Shah's Last Ride: The Fate of an Ally (New York: Simon and Schuster, 1988).

Sherman, Wendy. "Sunshine Through Cloudy Skies," Asian Perspective 26.3 (2002) 7.

Shirer, William L. 20th Century Journey: A Memoir of a Life and the Times - The Start, 1904-1930, Vol. 1 (New York: Simon and Shuster, 1976).

Sick, Gary. All Fall Down: America's Fateful Encounter with Iran (London: I.B. Tauris, 1985).

Simon, Sheldon. "Alternative Visions of Security in Northeast Asia," Journal of Northeast Asian Studies (Fall 1996).

Simon, Steve, and Daniel Benjamin. The Age of Sacred Terror: Radical Islam's War Against America (New York: Random House, 2003).

Simons, Geoff. Libya and the West: From Independence to Lockerbie (New York: Palgrave Macmillan 2003).

Singer, J. D. "The Level of Analysis Problem in International Relations," World Politics 14.1 (Oct. 1961) 77-92.

Skocpol, Theda. Social Revolutions in the Modern World (Cambridge: Cambridge University Press, 1994).

Skocpol, Theda. States and Social Revolutions: A Comparative Analysis of France, Russia and China (Cambridge: Cambridge University Press, 1979).

Smith, Derek D. Deterring America: Rogue States and the Proliferation of Weapons of Mass Destruction (Cambridge: Cambridge University Press, 2006).

Sneider, Richard L. The Political And Social Capabilities of North and South Korea for the Long-Term Military Competition (Santa Monica: Rand Corporation, 1985).

Snyder, Jack L. The Ideology of the Offensive: Military Decision Making and the Disasters of 1914 (Ithaca: Cornell University Press, 1984). 
Snyder, Jack, and Robert Jervis, eds. Coping With Complexity in the International System (Boulder: Westview Press, 1993).

Socialist People's Libyan Arab Jamahiriya. "Libyan Constitution: Preamble," English translation A. Tschentscher, 2004, International Constitutional Law Project, 17 May $2007<\mathrm{http}: / /$ www.servat.unibe.ch/law/icl/ly00000_html>.

Socialist People's Libyan Arab Jamahiriya. "Libya's Declaration on the Establishment of the Authority of the People, March 2, 1977, Article III," English trans. A. Tschentscher, 2004, International Constitutional Law Project, 20 May 2007 $<$ http://www.servat.unibe. ch/law/icl/ly01000_html $>$.

Sokolski, Henry, and James M. Ludes, eds. Twenty-First Century Weapons Proliferation: Are We Ready? forward John J. Fialka (London: Frank Cass, 2001).

Spero, Joan E., and Jeffery A. Hart, The Politics of International Economic Relations, 6th ed. (New York: Wadsworth, 2002).

Frieden, Jeffery R. "Third World Indebted Industrialization: International Finance and State Capitalism in Mexico, Brazil, Algeria, and South Korea," International Organization 35.30 (1981) 407-431.

South China Morning Post. "Rag-Tag Army Forced to Survive on Paltry Funds," South China Morning Post, 10 April 1999.

Staten, Clifford L. The History of Cuba (New York: Palgrave Macmillan, 2003).

Steinberg, Philip. The Social Construction of the Ocean (Cambridge: Cambridge University Press, 2001).

Stempel, John D. Inside the Iranian Revolution (Bloomington: Indiana University Press, 1981).

Stephen, John J. The Russian Far East: A History (Stanford: Stanford University Press, 1994).

Stockholm International Peace Research Institute. Military Expenditure Database 2004 (Stockholm: SIPRI, 2004), 15 April $2007<\mathrm{http}: / /$ web.sipri.org/contents/milap/m ilex/mex_data_index.html .

Stockholm International Peace Research Institute. Recent Trends in Military Expenditure: World Military Expenditure, 1988-2006 (Stockholm: SIPRI, 2006), 12 April $2007<$ www.sipri.org/contents/milap/milex/mex_trends.html>. 
Stockholm International Peace Research Institute. Stockholm International Peace Research Institute (SIPRI) Projects Homepage, 11 Nov. $2007<\mathrm{http}: / /$ projects.si pri.se/milex/mex_major_spenders.html $>$.

Stork, Joe. Middle East Oil and the Energy Crisis (New York: Monthly Review Press, 1975).

Stout, David. "Supreme Court Won't Hear Torture Appeal," New York Times Online, 9 Oct. 2007, 10 Oct. $2007<$ http://www.nytimes.com/2007/10/09/washington/09cn d-scotus.html?_r=1\&hp\&oref=slogin $>$.

Strange, Susan. "The Persistent Myth of Lost Hegemony," International Organization 41.4 (Fall 1987) 551-574.

Strange, Susan. "The Persistent Myth of Lost Hegemony: Reply to Milner and Snyder," International Organization 42.4 (Fall 1988) 751-52.

Strange, Susan. The Retreat of the State: The Diffusion of Power in the World Economy (Cambridge: Cambridge University Press, 1996).

Struck, Doug. "Citing Iraq, North Korea Signals Hard Line on Weapons Issue," Washington Post, 31 March 2003.

Stueck, William J., Jr. The Korean War: An International History (Princeton: Princeton University Press, 1995).

Suh, Dae-Sook. Kim Il Sung: The North Korean Leader (New York: Columbia University Press, 1988).

Suh, Dae-Sook. "The Military-First Politics of Kim Jong Il," Asian Perspective 26.3 (2002) Masan, Kyungnam University.

Suh, Jae-Jung. "Blitzkrieg or Sitzkrieg? Assessing A Second Korean War," Pacifica Review 11.2 (1999) 151-176.

Sullivan, Michael J., III. American Adventurism Abroad: 30 Invasions, Interventions, and Regime Changes Since World War II (Westport: Praeger, 2004).

Sung-yul, Lee. "Antique North Korean Naval Boats No Match for South's New Warships," The Korea Herald, 7 July 1999.

Szalontai, Balazs. "You Have No Political Line of Your Own: Kim Il Sung and the Soviets, 1953-1964," Cold War International History Project Bulletin 14 (2003), 10 April $2008<\mathrm{http} / /$ www.wilsoncenter.org/index.cfm?topic_id=1409 \&fuseacti on=topics.item\&news_id=19226>. 
Szulc, Tad. "Anti-Castro Units Trained To Fight At Florida Bases," 7 April 1961, New York Times, 24 May $2007<\mathrm{http}$ ://www.nytimes.com/library/world/americas/040 76l cuba-invasion.html>

Szulc, Tad. "Castro Says Attack Is Crushed; Cuba Rebels Give Up Beachhead, Report New Landings On Island," New York Times, 20 April 1961, 24 May $2007<$ http:// www.latinamericanstudies.org/bay-of-pigs/crushed.htm>.

Szulc, Tad. Fidel: A Critical Portrait (New York: William Morrow, 1986).

Taheri, Amir. The Spirit of Allah: Khomeini and the Islamic Revolution (London: Hutchison, 1985).

Tamayo, Juan O. "Fidel's Private Life With His Wife and Sons is so Secret that Even the CIA is Left to Wonder," The Miami Herald, 8 October 2000, 8 April 2007 $<$ www.latinamericanstudies.org/fidel/castro-family.htm $>$.

Tanter, Raymond. Rogue Regimes: Terrorism \& Proliferation (New York: St. Martin's Press, 1998).

Tarnoff, Peter. "U.S. Policy Toward Cuba," US Department of State Dispatch, vol. 6, 446-453, Washington D.C., 29 May 1995, 3 April $2008<$ http://findarticles.com /p/articles/mi_m1584/is_n22_v6/ai_17202370>.

Tetlock Philip E., and Charles B. McGuire, Jr. "Cognitive Perspectives on Foreign Policy," Political Behavior Annual, ed. S. Long (Boulder: Westview, 1985).

Thayer, Bradley A. "The Case for the American Empire," American Empire: A Debate, Bradley A. Thayer and Christopher Layne (New York: Routledge, 2007).

The History Channel. "History and Highlights of Cuba," The History Channel Online, 22 May $2007<$ http://www.history.com/encyclopedia.do?articleld=226919>.

The Islamic Republic of Iran. "Iranian Constitution, Preamble, 1992," English translation, Iranian Embassy, London, International Constitutional Law Project, 17 May $2007<$ http://www.servat.unibe.ch/law/icl/ir00000_html>.

The Republic of Cuba. "Constitution of the Republic of Cuba, 1992, Preamble," CUBANET DOCUMENTS, CubaNet News, Inc., Coral Gables, Florida, 17 May $2007<\mathrm{http}: / /$ www.cubanet.org/ref/dis/const_92_e.htm>.

The Washington File. "Senator Feinstein Calls for Direct Talks With North Korea," The Washington File, 15 April 2003, 12 April $2008<$ http://www.globalsecurity.org/w $\mathrm{md} /$ library/news/dprk/2003/dprk-030415-usia01.htm>. 
Thomas, Hugh. Cuba: Or the Pursuit of Freedom (New York: Da Capo Press, 1998).

Thornton, Richard C. Odd Man Out: Truman, Stalin, Mao and the Origins of the Korean War (Dulles: Brassey's, 2000).

Time/CNN Online. "An Interview With Qaddafi," Time/CNN Online, 9 April 1979, 28 May $2007<\mathrm{http} / /$ www.time.com/time/magazine/article/0,9171,920211,00.html>.

Time/CNN Online. “An Interview With Qaddafi," Time/CNN Online, 8 June 1981, 28 May $2007<\mathrm{http} / /$ www.time.com/time/magazine/article/0,9171,922551-1,00.h tml>.

Todorov, Tzvetan. "Structural Analysis of Narrative," The Norton Anthology of Theory and Criticism, eds., Vincent B. Leitch, William E. Cain, Laurie A. Fink, Barbara E. Johnson, John McGowan, and Jeffery J. Williams (New York: W.W. Norton, 2001).

Tolstoy, Leo. War and Peace, trans. Anthony Briggs, intro. Orlando Figes (New York: Penguin Books, 2006).

Triay, Victor A. Bay of Pigs: An Oral History of Brigade 2506 (Gainesville: University Press of Florida, 2001).

Triplett, William. How a Nuclear North Korea Threatens America (Washington D.C.: Regnery, 2004).

Unamuno, Miguel. Tragic Sense of Life, trans. J. E. Crawford Flitch, intro. Steven Schroeder (New York: Barnes \& Noble Publishing, 2006).

United Kingdom, Foreign \& Commonwealth Office. Countries \& Regions Profiles: Cuba, 10 August $2007<\mathrm{http}: / /$ www.fco.gov.uk/servlet/Front?pagename=Open Market $/$ Xcelerate $/$ ShowPage $\& c=$ Page $\&$ cid $=1007029394365 \& a=$ KCountryProfile \&aid=1029494280307>.

United Kingdom, Statutory Instruments 1996: 3171. "The Extraterritorial US Legislation: Sanctions Against Cuba, Iran and Libya. Protection of Trading Interests Order 1996," London, Stationery Office Books, 1997, 10 April 2008 <http://www.opsi.gov.uk/si/si1996/Uksi_19963171_en_1.htm.>

United Nations. The Nuclear Non-Proliferation Treaty, United Nations Online, 16 July $2007<\mathrm{http}: / /$ disarmament2.un.org/wmd/npt/index.html>.

United Nations, General Assembly. "Record Pertaining to Resolution Voting," United Nations Home Page, 5 June $2007<\mathrm{http}$ //www.un.org/english/>. 
United Nations, Security Council. Documents and Resolutions, 3 August $2007<\mathrm{http}: / /$ www.un.org/documents/scres.htm>.

United States Alien and Sedition Act of 1798. "Alien and Sedition Act of 1798," US Library of Congress, Primary Documents in American History: A Century of Lawmaking for a New Nation. US Congressional Documents and Debates, 1774 1875, Updated 31 May 2006, 7 June $2007<\mathrm{http} / / /$ www.loc.gov/rr/program/bib/ ourdocs /Alie.html>.

United States Central Intelligence Agency. "Family Jewels." Freedom of Information Act, 7 July $2007<\mathrm{http}: / / w w w$.foia.cia.gov/browse_docs_full.asp?doc_no $=0001$ 451843\& title $=\% 22$ FAMILY+JEWELS $\% 22 \&$ abstract $=\&$ no pages $=0702 \&$ pub date $=5 \% 2 \mathrm{~F} 16 \% 2 \mathrm{~F} 1973 \&$ release date $=6 \% 2 \mathrm{~F} 18 \% 2 \mathrm{~F} 2007 \&$ keywords $=\mathrm{FAMIL} \overline{\mathrm{Y}}+$ JEWELS\&case_no $=F \% 2 D 1992 \% 2 D 00353 \&$ copyright $=0 \&$ release dec $=$ RIPPUB $\&$ classification $=\mathrm{U} \&$ showPage $=0001>$.

United States Central Intelligence Agency. CIA World Factbook, 12 Feb. 2007 <www. cia.gov/cia/publications/factbook/geos/kn.html>.

United States Central Intelligence Agency. CIA World Factbook, 3 March $2007<$ www. cia.gov/cia/publications/factbook/geos/cu.html>.

United States Central Intelligence Agency. CIA World Factbook, 16 March 2007 $<$ https://www.cia. gov/cia/publications/factbook/geos/ly.html $>$.

United States Central Intelligence Agency. CIA World Factbook, 16 March 2007 $<$ https://www.cia.gov/redirects/factbook redirect.html $>$.

Unites States Code. "United States Code (USC), Title 18, Part I., Chapter 115, § 2385 Advocating Overthrow of Government," Cornell University Law School Legal Information Institute, 7 June $2007<\mathrm{http} / / \mathrm{www}$.law.cornell.edu/uscode/html/us code18/usc_sec_18_00002385----000-.html>.

United States Congress, House of Representatives Committee on Internal Security. "Hearings on Domestic Intelligence Operations for Internal Security Purposes," $93^{\text {rd }}$ Cong., $2^{\text {nd }}$ sess., 1974.

United States Congress, House of Representatives Select Committee on Intelligence. "Hearings on Domestic Intelligence Programs," $94^{\text {th }}$ Cong., $1^{\text {st }}$ sess., 1975.

United States Congress, Senate Committee on Government Operations, Permanent Subcommittee on Investigations. "Hearings on Riots, Civil, and Criminal Disorders," 90th Cong., $1^{\text {st }}$ sess. $-91^{\text {st }}$ Cong., $2^{\text {nd }}$ sess., 1967-1970. 
United States Congress, Senate Select Committee to Study Governmental Operations with Respect to Intelligence Activities. "Final Report, Book II, Intelligence Activities and the Rights of Americans," $94^{\text {th }}$ Cong., $2^{\text {nd }}$ sess., 1976.

United States Congress, Senate Select Committee to Study Governmental Operations with Respect to Intelligence Activities. "Final Report, Book III, Supplementary Detailed Staff Reports on Intelligence Activities and the Rights of Americans," $94^{\text {th }}$ Cong., $2^{\text {nd }}$ sess., 1976.

United States Congress, Senate Select Committee to Study Governmental Operations with Respect to Intelligence Activities. "Hearings: Federal Bureau of Investigation," vol. 6., $94^{\text {th }}$ Cong., $1^{\text {st }}$ sess., 1975.

United States Congress, Senate Select Committee to Study Governmental Operations with Respect to Intelligence Activities. "Hearings: The National Security Agency and Fourth Amendment Rights," vol. 6., $94^{\text {th }}$ Cong, $1^{\text {st }}$ sess., 1975.

Unites States Department of Defense. Nuclear Posture Review Report, Submitted to Congress, 31 December 2001, released 8 January 2002, Washington, D.C., 2002, 16 May $2007<$ http://www.globalsecurity.org/wmd/library/policy/dod/npr.htm>.

Unites States Department of Defense. Quadrennial Defense Review Report 2001, 30 September 2001, 13 May 2007 <http://www.defenselink.mil/pubs/qdr2001.pdf>.

Unites States Department of Defense. US Korean War Commemoration, 27 May 2007 $<$ http:// korea50.army.mil/history/factsheets/Histog.shtml>.

Unites States Department of State. "American Foreign Policy: Basic Documents, 19771980, JX 1417 A56 1977-80 REF-67," Washington, D.C., GPO, 1983.

United States Department of State, Bureau of East Asian and Pacific Affairs.

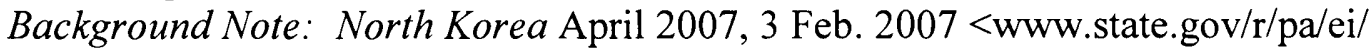
bgn/2792.htm\#political>.

United States Department of State, Bureau of East Asian and Pacific Affairs. Background Note: North Korea, April 2007, 28 May $2007<$ http://www.state. gov/r/pa/ei/bgn/2792.htm $>$.

Unites States Department of State, Bureau of Near Eastern Affairs. Background Note: Libya, February 2007," 19 May $2007<$ http://www.state.gov/r/pa/ei/bgn/5425.ht m\#gov>.

United States Department of State, Bureau of Western Hemisphere Affairs. Background Note: Cuba, 17 May $2007<\mathrm{http}: / /$ www.state.gov/r/pa/ei/bgn/2886.htm>. 
Unites States Department of State. Country Reports on Terrorism, Office of the Coordinator for Counterterrorism, 28 April 2006, 23 June $2007<$ http://www.stat e.gov/s/ct/rls/crt/2005/66236.htm.>

United States Department of State. Country Reports on Terrorism, Office of the Coordinator for Counterterrorism, 28 April 2006, Chapter 6, State Sponsors of Terror Overview, 17 May 2007 <www.state.gov/s/ct/rls/crt/2005/64337.htm>.

Unites States Department of State. Country Reports on Terrorism, Office of the Coordinator for Counterterrorism, 28 April 2006, Chapter 7, The Global Challenge of WMD Terrorism, 15 May $2007<$ www.state.gov/s/ct/rls/crt/2005/ 64660.htm>.

United States Department of State. Country Reports on Terrorism, Office of the Coordinator for Counterterrorism, 28 April 2006, Chapter 8, Foreign Terrorist Organizations, 11 May 2007 <www.state.gov/s/ct/rls/crt/2005/65275.htm>.

Unites States Department of State. Office of the Coordinator for Counterterrorism. Patterns of Global Terrorism 1995, Washington, D.C., April 1996, 15 June 2007 $<$ http://www.usis.usemb.se/terror/rpt1995/ index.html>.

Unites States Department of State. "Report of the US State Department on North Korean Human Rights," US Department of State, Washington, D.C., 1 Aug. 2007 <www. state.gov/g/drl/rls/hrrpt/2003/27775pf.htm>.

United States Government, The White House, 9/11 Five Years Later: Successes and Challenges, September 2006, 21 Aug. $2008<\mathrm{http}: / /$ www.whitehouse.gov/nsc/wa ronterror/2006/sectionIII.html>.

United States Government, The White House. Fact Sheet: Protecting America From Terrorism, 20 Aug. 2008, 20 Aug. $2008<$ http://www.whitehouse.gov/infocus/nat ionalsecurity/>.

United States Government, The White House. The National Security Strategy of the United States of America, March 2006, 30 May $2007<w w w . w h i t e h o u s e . g o v / n s c /$ nss/2006/>.

United States Government, The White House. The National Strategy for Homeland Security, Oct. 2007, 19 Aug. $2008<$ http://www.whitehouse.gov/infocus/homelan d/nshs/ 2007/index.html $>$.

United States Government, The White House. National Strategy for Information Sharing October 2007, 19 Aug. 2008 <http://www.whitehouse.gov/nsc/infosharing/index.html>. 
United States Government, The White House. United States National Strategy for Combating Terrorism, Sept. 2006, 30 May $2007<w w w . w h i t e h o u s e . g o v / n s c / n s c t /$ 2006/>.

United States Library of Congress, Federal Research Division. Country Study: Libya, 21 May $2007<$ http://lcweb2.loc.gov/cgi-bin/query/r?frd/cstdy:@field(DOCID+1 y0009)>.

United States Library of Congress, Federal Research Division. Country Study: North Korea, 2 Feb. $2007<$ http://memory.loc.gov/frd/cs/kptoc.html>.

United States Library of Congress, Federal Research Division. Country Study: North Korea, 12 Feb. $2007<$ http://lcweb2.loc.gov/cgi-bin/query/r?frd/cstdy:@field(DO CID+kp0108)>.

United States Library of Congress, Federal Research Division. Country Study: North Korea, 9 Nov. 2005, 27 May $2007<$ http://lcweb2.loc.gov/frd/cs/kptoc.html>.

United States National Security Council. "NSC 68: United States Objectives and Programs for National Security, April 14, 1950: A Report to the President Pursuant to the President's Directive, January 31, 1950," Naval War College Review 27 (May/June 1975) 51-108, 5 June 2007 <http://www.mtholyoke.edu/ $\mathrm{acad} /$ intrel/nsc-68/nsc68-1.htm>.

United States Patriot Act 2001. UNITING AND STRENGTHENING AMERICA BY PROVIDING APPROPRIATE TOOLS REQUIRED TO INTERCEPT AND OBSTRUCT TERRORISM ACT (USA PATRIOT ACT) OF 2001, PUBLIC LAW 107-56 [H.R. 3162] 26 OCT 2001, 107 P.L. 56; 115 Stat. 272; 2001 Enacted H.R. 3162; 107 Enacted H.R. 3162, 12 August $2007<$ http://web.lexisnexis.com.ezpro xy.fiu.edu/congcomp/document? m=1cd1193c5e82a 79765a3143c9728537a\&_ docnum $=1 \& w c h p=d G L b V t z z S k S A \&$ md5 $=9 f f 964 \mathrm{e} 9 \mathrm{~b} 9 \mathrm{fd} 4 \mathrm{e} 55 \mathrm{efd} 3 \mathrm{~b} 299 \mathrm{~d} 1991 \mathrm{e}$ 69>.

Urquhart, Bruce. "World Order \& Mr. Bush," New York Review of Books, 9 October 2003, 4 March $2008<$ http://warincontext.org/2003_09_21_archive.html $>$.

USC-UCLA Joint East Asian Studies Center. "Treaty of Annexation (Annexation of Korea by Japan), 22 August 1910," USC-UCLA Joint East Asian Studies Center, East Asian Studies Documents, 27 May $2007<\mathrm{http}$ ://www.isop.ucla.edu/eas/doc uments/kore1910.htm>.

Utgoff, Victor A. "Missile Defense \& American Ambitions," The Use of Force: Military Power and International Politics, $6^{\text {th }}$ ed., eds. Robert J. Art and Kenneth N. Waltz (Lanham: Rowman, 2004). 
Valencia, Mark J. The Proliferation Security Initiative: Making Waves in Asia (New York: Routledge, 2006).

Van Evera, Stephen. Causes of War: Power \& the Roots of Conflict (Ithaca: Cornell University Press, 1999).

Van Ness, Peter. "The North Korea Nuclear Crisis: Four-Plus-Two, An Idea Whose Time Has Come," Confronting the Bush Doctrine: Critical Views From the AsiaPacific, eds. Mel Gurtov and Peter Van Ness (London: Routledge-Curzon, 2005).

Vandewalle, Dirk. Libya Since Independence: Oil and State-Building (Ithaca: Cornell University Press, 1998).

Varhola, Michael J. Fire and Ice: The Korean War 1950-1953 (Mason City: Savas Publishing Co., 2000).

Vasquez, John A., ed. Classics in International Relations, $2^{\text {nd }}$ ed. (Englewood Cliffs: Prentice Hall, 1986).

Vatanka, Alex. "North Korea Special Report," Jane's Sentinel, 20 Feb. 2003, 39-79.

Voss, Michael. “Absent Fidel 'in Cubans' Hearts,"” BBC News Online, 26 July 2007, 20 August $2007<\mathrm{http}: / /$ news.bbc.co.uk/2/hi/americas/6918409.stm>.

Voss, Michael. "Fidel's Presence Still Keenly Felt in Cuba," BBC News Online, 31 July 2007, 8 Aug. $2007<$ http://news.bbc.co.uk/2/hi/americas/6925085.stm>.

Walker, R.B.J. Inside/Outside: International Relations as Political Theory (New York: Cambridge University Press, 1993).

Wallerstein, Immanuel. "The Rise and Future Demise of the World Capitalist System," Comparative Studies in Society \& History 16 (1974) 387-415.

Walt, Steven. "The Renaissance of Security Studies," International Studies Quarterly 35.2 (June 1991) 211-239.

Waltz, Kenneth N. Man, the State, and War: A Theoretical Analysis (New York: Columbia University Press, 2001).

Waltz, Kenneth N. "Missile Defenses and the Multiplication of Nuclear Weapons," The Use of Force: Military Power and International Politics, $6^{\text {th }}$ ed., eds. Robert J. Art and Kenneth N. Waltz (Lanham: Rowman 2004). 
Waltz, Kenneth N. "Nuclear Myths and Political Realities," The Use of Force: Military Power and International Politics, $6^{\text {th }}$ ed., eds. Robert J. Art \& Kenneth N. Waltz (Lanham: Rowman, 2004).

Waltz, Kenneth N. "The Spread of Nuclear Weapons: More May Be Better," Conflict After the Cold War: Arguments on Causes of War \& Peace, $2^{\text {nd }}$ ed., ed. Richard K. Betts (New York: Pearson-Longman, 2002).

Waltz, Kenneth N. Theory of International Politics (New York: McGraw Hill, 1979).

Weeks, Stanley B., and Charles A. Meconis. The Armed Forces of the USA in the AsiaPacific Region (New York: I. B. Tauris, 1999).

Weiner, Myron. "Security, Stability, and International Migration," International Security 7.3 (Winter 1992-1993) 91-126.

Wendt, Alexander. "Anarchy is What States Make of It: The Social Construction of Power Politics," International Organization 46.2 (Spring 1992) 391-425.

Wendt, Alexander. "Constructing International Politics," International Security 20.1 (Summer 1995) 71-81.

White, Mark J. ed. The Kennedy's \& Cuba: The Declassified Documentary History (Chicago: Ivan R. Dee, 1999).

Whitehead, Alfred North. The Aims of Education \& Other Essays (New York: Free Press, 1967).

Whitehead, John W., and Steven H. Aden. "Forfeiting 'Enduring Freedom' for 'Homeland Security': A Constitutional Analysis of the USA PATRIOT Act \& the Justice Department's Anti-Terrorism Initiatives," 51 Am. U.L. Rev. 1081, The American University Law Review (August 2002) 12 Jan. $2007<\mathrm{http} / / /$ web.lexisnexis.com>.

Wight, Martin, ed. Iran: The Khomeini Revolution (Chicago: St. James Press, 1989).

Wise-Bauer, Susan. The History of the Ancient World: From the Earliest Accounts to the Fall of Rome (New York: W.W. Norton, 2007).

Wittgenstein, Ludwig. Culture \& Value, trans. Peter Winch (Chicago: University of Chicago Press, 1980).

Wittgenstein, Ludwig. On Certainty, trans. Dennis Paul and G. E. M. Anscombe, eds. G. E. M. Anscombe and G. H. von Wright (New York: Harper, 1969). 
Wittgenstein, Ludwig. Tractatus Logico Philosophicus, trans. David Pears and Brian McGuinness, intro. Bertrand Russell (New York: Routledge, 2001).

Wolf, Charles, Jr., and Kamil Akramov. North Korean Paradoxes: Circumstances, Costs, and Consequences of Reunification (Santa Monica: Rand Corporation, 2005).

Wolfers, Arnold. "National Security as an Ambiguous Symbol," Political Science Quarterly 67 (Dec. 1952) 481-502.

Woodward, Bob. Bush at War (New York: Simon \& Schuster, 2002).

Woodward, Susan L. "Genocide or Partition: Two Faces of the Same Coin?" Slavic Review 55.4 (Winter 1996) 755-761.

Wright, John. Libya: A Modern History (Baltimore: Johns Hopkins University Press, 1982).

Wright, Quincy. A Study of War, $2^{\text {nd }}$ ed. (Chicago: Chicago University Press, 1965).

Wright, Robin. The Last Great Revolution: Turmoil and Transformation in Iran (New York: Vintage Books, 2001).

Yapp, M. E. The Near East Since the First World War: A History to 1995 (London: Longman, 1996).

Zakaria, F. "The Politics of Rage: Why Do They Hate Us?" Newsweek, 15 Oct. 2001, 11 April $2008<$ http://www.fareedzakaria.com/articles/newsweek/101501_why.htm $1>$.

Zepezauer, Mark. The CIA's Greatest Hits (Tucson: Odonian, 1994).

Zhang, Shu-gang. Mao's Military Romanticism: China and the Korean War 1950-1953 (Lawrence: University Press of Kansas, 1995).

Zhebin, Alexander. "The Bush Doctrine, Russia, and Korea," Confronting the Bush Doctrine: Critical Views From the Asia-Pacific, eds. Mel Gurtov and Peter Van Ness (London: Routledge-Curzon, 2005).

Zizek, Slavoj. Welcome to the Desert of the Real (London/New York: Verso, 2002). 
Born, New Haven, Connecticut

1995

1998

March-June 2000

January 2005-August 2005

August 2005-May 2006

2006

May 2006-August 2006

August 2006-May 2007

2007
B.A., Political Science, Magna Cum Laude

University of Connecticut, Storrs

M.A., Liberal Studies/Government

Wesleyan University

Middletown, Connecticut

Teacher, American History/Legal Studies

Silver Trail Middle School

Pembroke Pines, Florida

Research Assistant, Cuban Research Institute Florida International University

Miami, Florida

Graduate Teaching Assistant

Florida International University

Miami, Florida

C.A.S., Liberal Studies/Government

Wesleyan University

Middletown, Connecticut

Research Assistant, Applied Research Center Military and International Affairs

Florida International University

Miami, Florida

Graduate Teaching Assistant

Florida International University

Miami, Florida

M.A., International Studies

Florida International University

Miami, Florida 
May 2007-August 2007

August 2007-December 2007

January 2008-Present
Adjunct Professor, Dept. of International Relations Florida International University

Miami, Florida

Adjunct Professor, Dept. of Social Sciences

Miami Dade College, West Campus

Doral, Florida

Graduate Teaching Assistant

Florida International University

Miami, Florida

Presidential Dissertation Fellow $(\$ 25,000.00$

University Graduate School Fellowship)

Florida International University

Miami, Florida

\section{PUBLICATIONS AND PRESENTATIONS}

Astrada, Marvin. Abortion \& US Supreme Court Discourse: An Analysis of Planned Parenthood v. Casey \& the Construction of Legal Actuality (CAS Thesis, Wesleyan University, 2006).

Astrada, Marvin and Helga Turku (March 2007). Theoretic Ruminations on Power, Control \& Feminist Discourse in International Relations. Paper presented at the International Studies Association National Conference, Chicago, Illinois.

Astrada, Marvin (October 2007). Conceptualizing US Power \& Security in a Post-Cold War, Post-9/11 World: Unipolarity, Conflict, Resistance \& the Postulation of Global Security. Paper presented at the International Studies Association South, Savannah, Georgia.

Astrada, Marvin (November 2007). Global Security in a Post-9/11 Security Environment. Paper presented at the Florida International University Graduate Scholarly Forum, Miami, Florida.

Astrada, Marvin (March 2008). US Power, Global Security \& Rogue States. Paper presented at the International Studies Association National Conference, San Francisco, California.

Astrada, Marvin (October 2008). A Systems Analysis of Global Security in a Post-9/11 International Order. Paper presented at the International Studies Association North East, Baltimore, Maryland. 